\title{
14. SITE $682^{1}$
}

\author{
Shipboard Scientific Party ${ }^{2}$
}

\section{HOLE 682A}

\section{Date occupied: 0045 L, 9 November 1986}

Date departed: 1715 L, 14 November 1986

Time on hole: $136 \mathrm{hr} 30 \mathrm{~min}$

Position: $11^{\circ} 15.99^{\prime} \mathrm{S}, 79^{\circ} 03.73^{\prime} \mathrm{W}$

Water depth (sea level; corrected m, echo-sounding): 3788.5

Water depth (rig floor; corrected m, echo-sounding): 3799.0

Bottom felt (m, drill pipe): 3801.3

Penetration (m): 436.7

Number of cores: 48

Total length of cored section (m): 436.7

Total core recovered $(\mathrm{m}): 127.04$

Core recovery $(\%): 29.1$

Oldest sediment cored

Depth (mbsf): 436.7

Nature: Mud and mudstone

Age: Eocene

Measured velocity $(\mathrm{km} / \mathrm{s}): 1.65$

\footnotetext{
${ }^{1}$ Suess, E., von Huene, R., et al., 1988. Proc. ODP, Init. Repts., 112: College Station, TX (Ocean Drilling Program).

${ }^{2}$ Erwin Suess (Co-Chief Scientist), Oregon State University, College of Oceanography, Corvallis, OR 97331; Roland von Huene (Co-Chief Scientist), U.S. Geological Survey, Branch of Pacific Marine Geology, 345 Middlefield Rd. M/S 999, Menlo Park, CA 94025; Kay-Christian Emeis (ODP Staff Scientist), Ocean Drilling Program, Texas A\&M University, College Station, TX 77843; Jacques Bourgois, Département de Géotectonique, Université Pierre et Marie Curie, 4 Place Jussieu, 75230 Paris Cedex 05, France; José del C. Cruzado Castañeda, Petroleos del Peru S. A., Paseo de la Republica 3361, San Isidro, Lima, Peru; Patrick De Wever, CNRS, Laboratoire de Stratigraphie, Université Pierre et Marie Curie, 4 Place Jussieu, 75230 Paris Cedex 05, France; Geoffrey Eglinton, University of Bristol, School of Chemistry, Cantock's Close, Bristol BS8 1TS, England; Robert Garrison, University of California, Earth Sciences, Applied Sciences Building, Santa Cruz, CA 95064; Matt Greenberg, Lamont-Doherty Geological Observatory, Columbia University, Palisades, NY 10964; Elard Herrera Paz, Petroleos del Peru, S. A., Paseo de la Republica 3361, San Isidro, Lima, Peru; Phillip Hill, Atlantic Geoscience Centre, Bedford Institute of Oceanography, Box 1006, Dartmouth, Nova Scotia B2Y 4A2, Canada; Masako Ibaraki, Geoscience Institute, Faculty of Science, Shizuoka University, Shizuoka 422, Japan; Miriam Kastner, Scripps Institution of Oceanography, SVH, A-102, La Jolla, CA 92093; Alan E. S. Kemp, Department of Oceanography, The University, Southampton SO9 5NH, England; Keith Kvenvolden, U.S. Geological Survey, Branch of Pacific Marine Geology, 345 Middlefield Rd., M/S 999, Menlo Park, CA 94025; Robert Langridge, Department of Geological Sciences, Queen's University at Kingston, Ontario K7L 3A2, Canada; Nancy Lindsley-Griffin, University of Nebraska, Department of Geology, 214 Bessey Hall, Lincoln, NE 68588-0340; Janice Marsters, Department of Oceanography, Dalhousie University, Halifax, Nova Scotia B3H 4J1, Canada; Erlend Martini, Geologisch-Paläontologisches Institut der Universität Frankfurt, Senckenberg-Anlage 32-34, D-6000, Frankfurt/Main, Federal Republic of Germany; Robert McCabe, Department of Geophysics, Texas A\&M University, College Station, TX 77843; Leonidas Ocola, Laboratorio Central, Instituto Geofisico del Peru, Lima, Peru; Johanna Resig, Department of Geology and Geophysics, University of Hawaii, Honolulu, HI 96822; Agapito Wilfredo Sanchez Fernandez, Instituto Geologico Minero y Metalurgico, Pablo Bermudez 211, Lima, Peru; Hans-Joachim Schrader, College of Oceanography, Oregon State University, Corvallis, OR 97331 (currently at Department of Geology, University of Bergen, N-5000 Bergen, Norway); Todd Thornburg, College of Oceanography, Oregon State University, Corvallis, OR 97331; Gerold Wefer, Universität Bremen, Fachbereich Geowissenschaften, Postfach 330 440, D-2800 Bremen 33, Federal Republic of Germany; Makoto Yamano, Earthquake Research Institute, University of Tokyo, Bunkyo-ku, Tokyo 113, Japan.
}

Principal results: Our objectives at Site 682 resulted from tectonic studies during the Nazca Plate Project, which indicated that the continental crust extended to the lower slope of the Peru Trench. Recovery of basement sediments from a drill hole near the front of the margin could have supported this hypothesis. Although the basement was not penetrated at Site 682, the overlying section is continental crust because the cores contain Eocene through Quaternary terrigenous upper-slope sediment. The site was located on part of the Peruvian continental margin before the Neogene Andean orogeny, rather than on an element accreted during that orogeny.

The lithostratigraphy and biostratigraphy of the $436.7 \mathrm{~m}$ penetrated record three tectonic/paleoceanographic environments. The first $267 \mathrm{~m}$ records diatomaceous sedimentation that began in the middle Miocene. This sediment, which accumulated in a typical continental slope environment, consists of mud and materials derived from upwelling systems upslope. These sediments contain all the diagenetic products associated with upwelling sediment except for phosphorites. The Quaternary and Pliocene sediment section is composed of poorly laminated diatomaceous mud mixed with terrigenous sand. The benthic-foraminifer assemblages lived in a depth zone corresponding to today's water depths. Paleontological evidence indicates a relatively brief hiatus at the Miocene/Pliocene boundary (110 mbsf) associated with a spectacular zone of slump folds and a change in the reflectivity of seismic horizons. The underlying upper Miocene diatomaceous mudstone is more consolidated; it fractures readily and deforms brittlely. The benthic-foraminifer assemblages lived at middle, rather than lower, bathyal depths. Approximately $30 \mathrm{~m}$ below the hiatus, the sediment is composed of displaced lower-Miocene nannofossils, benthic foraminifers, and a mixed assemblage of diatoms that eroded from an area upslope, where erosion was observed in seismic records. These transported components were noted through part of the upper and upper-middle Miocene to about $\mathbf{2 7 5}$ mbsf. A zone of poor recovery that yielded only gravel marked another abrupt increase in consolidation of the sediment.

The second sequence (320-387 mbsf), a section of lower to middle Miocene mudstones, is texturally coarser, more terrigenous, and less diatomaceous than those above. The inhomogeneous lithologies indicate a varied continental slope environment. The benthic-foraminifer assemblages have middle bathyal affinities.

A major hiatus that probably includes most of the late Eocene time separates the second and third sediment sequences. Rare clasts indicate proximity to continental basement and the recovery of only gravel corresponds in character to the higher-than-background amplitude and broken reflections observed in seismic records. This rough reflective zone, interpreted as basement during site selection, extends at least $10 \mathrm{~km}$ across the slope. The extent as well as the hiatus of $15 \mathrm{Ma}$ duration indicate an important unconformity that perhaps is associated with lowered sea levels during the Oligocene. The middle and lower Eocene rocks below this hiatus are silty mudstones and sandstones that are locally cemented by authigenic carbonate. These rocks exhibit pervasive scaley fractures as well as deformation in a semilithified state. Thus, in addition to deformation from downslope remobilization, a tectonic imprint of deformation from deeper faults also exists. Transported elements include shallow-water nannofossils and Cretaceous nannofossils. The in-situ benthic-foraminifer assemblages lived at upper to upper-middle bathyal water depths.

The presence of gas hydrates below about 100 mbsf was inferred from increased chlorinity above that part of the sedimentary section characterized by high concentrations of methane. This chloride enrichment was attributed to enrichment of dissolved ions in a residual brine during the formation of the hydrate. A second observation attributed to gas hydrates was decreasing salinity and chlorinity in pore waters with depth. Although we did find evidence for the pres- 
ence of gas hydrates in the pore-water chemistry, we did not observe hydrates in samples examined in the laboratory. The hydrocarbon gases show an overall decrease in the methane/ethane ratio in a manner normal for deep-sea sediments. However, we did encounter three isolated abrupt decreases in the methane/ethane ratio. We concluded that below a threshold drilling rate, heat from friction of the drill bit thermally alters the sedimentary organic matter. Thus, hydrocarbon gases are produced artificially, including some that do not normally occur in a natural environment, such as ethene.

\section{BACKGROUND AND SCIENTIFIC OBJECTIVES}

Site 682 is located on the landward lower slope of the Peru Trench at a water depth of $3788 \mathrm{~m}$ (Fig. 1). Samples from this site were studied (1) to establish the continental or oceanic origin of the crystalline basement in a location near this trench, (2) to establish the history of vertical tectonism, and (3) to sample the associated stratigraphy of explosive volcanism and distal material from upwelling on the continental shelf. Procedural constraints required that we select the site before reprocessing two records in the southern transect area. Thus, the geophysical background was derived from seismic images on other lines (EDP-1 and 1017; see Chapter 6, this volume).

We have known since the early stages of the Nazca Plate Project that the Peru Margin was underlain (1) by crystalline basement with continental affinities out to its upper slope and (2) by an accretionary complex beneath its lower slope. However, some researchers thought that the boundary between continental basement and the accretionary complex was near the trench axis (Kulm et al, 1981; Hussong and Wipperman, 1981), whereas others placed it beneath the edge of the shelf (Jones, 1981). Reprocessing of a multichannel seismic record off central Peru narrowed the zone of transition to between 10 and $15 \mathrm{~km}$ landward of the trench axis (von Huene et al, 1985). However, this boundary is not so apparent, even in reprocessed seismic records off southern Peru (von Huene and Miller, unpubl.). The boundary there was inferred to be within $5 \mathrm{~km}$ of the trench axis (Hussong and Wipperman, 1981). However, a convincing case based on geophysical data alone does not exist.
Seismic record Peru 1, which was studied using unmigrated images by Hussong and Wipperman (1981), was reprocessed shortly before Leg 112 (von Huene and Miller, this volume). A seismic record located about $20 \mathrm{~km}$ south of the JOIDES Resolution site survey and released to us by Shell International Petroleum Co., (Shell 1017) had been reprocessed previously and showed similar tectonic features. From these records, we were able to project a sediment section in the midslope area to the site area. Transition from the middle to the lower slope results in a zone having small normal faults that increase in frequency downslope. Near the site, the individual faults can no longer be resolved by the seismic methods we used and thus Site 682 is in an area of poor seismic resolution. Before drilling Site 679, the slope deposits were believed to be of Neogene and late Paleogene age; penetration of the upper/middle Miocene hiatus just $100 \mathrm{~m}$ above basement at Site 679 , however, indicated that the sediment covering the slope was much younger.

\section{OPERATIONS}

The ship departed Site 681 on 8 November 1986 at 1800 UTC and steamed for $7 \mathrm{hr}$ to the vicinity of Site 682 , where our geophysical gear was deployed to locate the site and drop a beacon. Because the Resolution steamed past the point where the survey was to begin, we had to come about and run the survey in the direction opposite the one we had planned (Fig. 2). We dropped a beacon at $0138 \mathrm{hr}, 9$ November, based on dead reckoning and water depth. After holding steady on the beacon in a water depth of $3789 \mathrm{~m}$, we obtained a satellite position indicating that the ship was correctly located.

We penetrated the seafloor and recovered our first advanced piston corer (APC) core at $1400 \mathrm{~L}$ (Table 1). Because the sediment was unusually stiff, we could no longer use the APC after Core $112-682 \mathrm{~A}-4 \mathrm{H}$ and were required to begin using the extended-core barrel corer (XCB). XCB recovery was low, averaging only about $20 \%$. Despite attempts to improve recovery using many different combinations of drilling parameters, all attempts failed. At about 300 mbsf, recovery improved to about $40 \%$ in

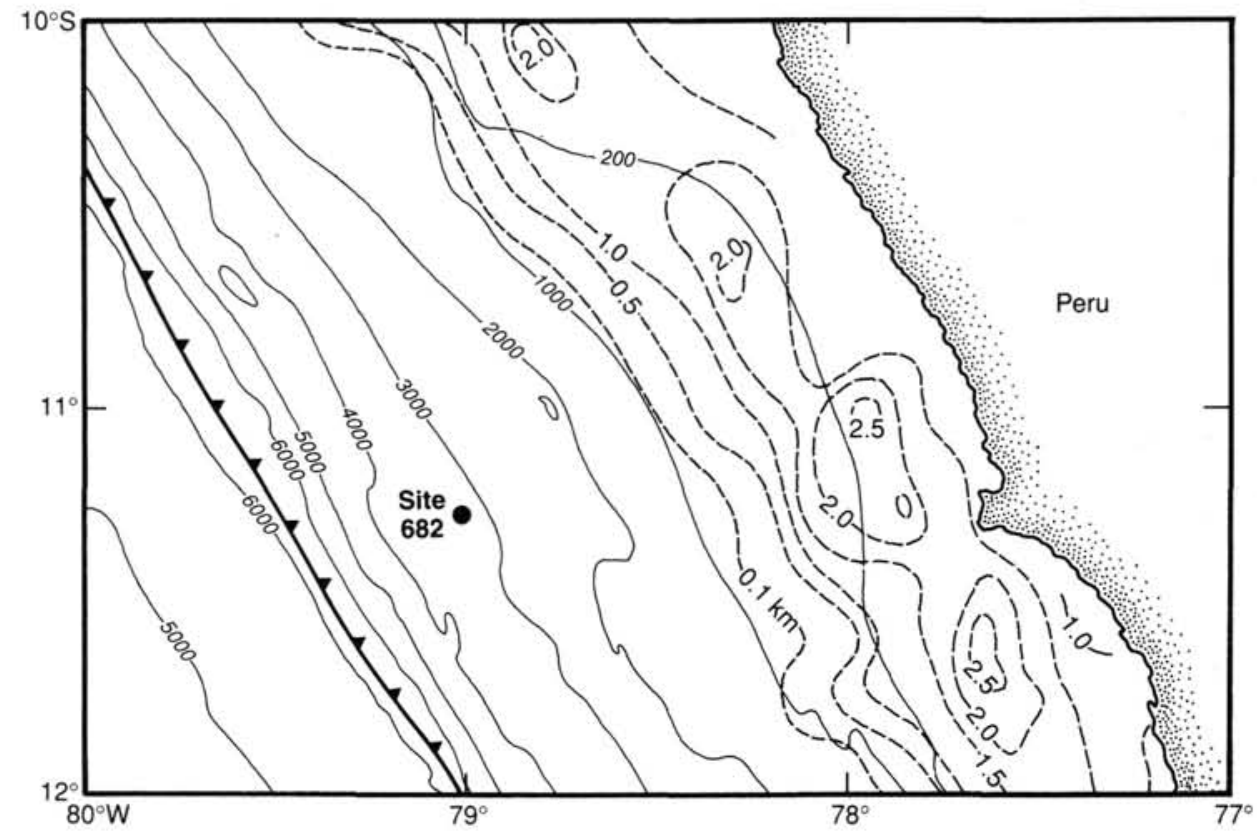

Figure 1. Bathymetry and sediment isopachs along Peru Continental Margin at $11^{\circ} \mathrm{S}$ and location of Site 682; depth intervals are in increments of $1000 \mathrm{~m}$, beginning at $200 \mathrm{~m}$ of water depth; sediment isopachs in increments of $0.5 \mathrm{~km}$ beginning at $0.1 \mathrm{~km}$; for overview of all sites see Fig. 1 of Site 679 chapter. 


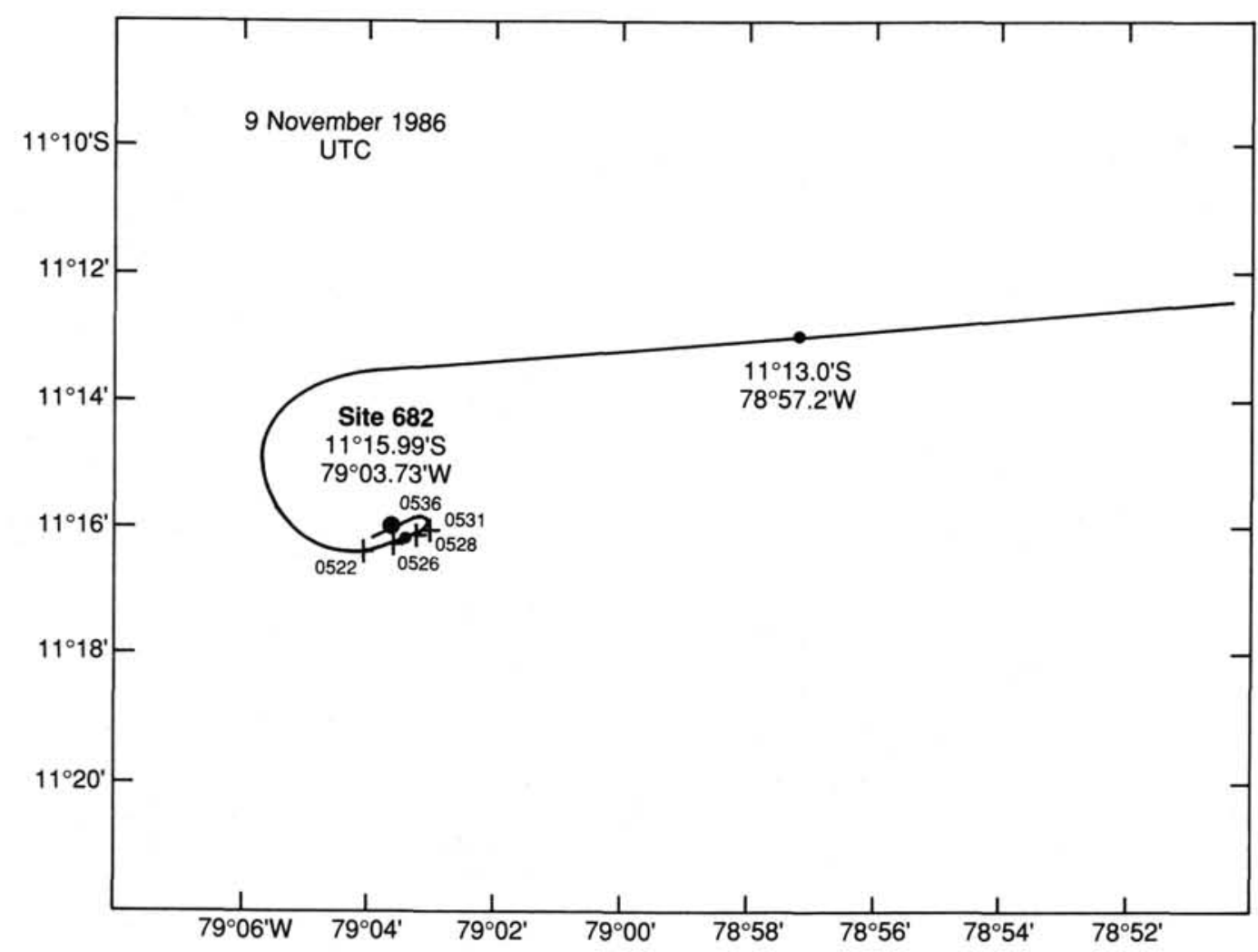

Figure 2. Track chart of approach to Site 682 .

an interval where the drilling rate slowed but then decreased again below that depth.

At about 390 mbsf hole conditions began to deteriorate, and we experienced back-fill and increased drilling torque. After cutting Core 112-682A-48X at $437 \mathrm{mbsf}$, the pipe stuck while we were making a connection. It could not be freed despite $3 \mathrm{hr}$ of working. Indications at the surface suggested that further attempts would be futile, and so we severed the pipe using explosives and left the bottom-hole assembly implanted.

Rather than trying to drill another hole to reach the basement, we decided to move to the next site. Drilling another hole would only have lost another day of our available drilling time (already 6 days behind) and endangered other objectives. In addition, the seismic record on which this site was selected was poor and gave only a vague indication of basement about $100 \mathrm{~m}$ deeper. The original "basement" reflection turned out to have been a gravel zone that was penetrated during drilling.

\section{LITHOSTRATIGRAPHY}

\section{Lithologic Units}

The sediments recovered at Site 682 are divided into four lithologic units (Table 2; Fig. 3) based on visual core descriptions, smear-slide analyses, carbonate determinations (Table 3; Fig. 4), drilling penetration rates (Fig. 5), and correlation with biostratigraphic, geochemical, and physical-properties data. Unit I is further divided into four subunits.

\section{Unit I}

Cores 112-682A-1H-1 through 112-682A-12X, CC; depth, 0-114 mbsf; age, Pliocene to Quaternary.

\section{Subunit IA}

Subunit IA extends from 0 to $14 \mathrm{mbsf}$ and is in gradational contact with the underlying, more calcareous, lithologies of Sub- unit IB (Table 2, Fig. 3). The unit consists of foraminifer-bearing diatomaceous mud, olive gray to dark olive gray ( $5 Y 4 / 2$ to $5 Y 3 / 2$ ), homogenous to mottled, with common evidence of bioturbation (Fig. 6). Diatom contents typically range from $20 \%$ to $30 \%$. Smear-slide estimates of foraminifer contents average $5 \%$ to $10 \%$ and agree well with bulk $\mathrm{CaCO}_{3}$ values, which range from $0 \%$ to $13 \%$ throughout this interval (Fig. 4). (Note: anomalously high carbonate values near $7.6 \mathrm{mbsf}$ represent a thin interbed of calcareous deposits similar to those found in Subunit IB.) Occasionally, broken shell fragments are present. Thin, bioturbated laminae of terrigenous, foraminifer sands may have been winnowed from the muddy intervals by bottom currents.

\section{Subunit IB.}

Subunit IB is classified as a foraminifer- and nannofossilbearing diatomaceous mud that is significantly enriched in both biogenic carbonate (foraminifers: $5 \%$ to $10 \%$; nannofossils: $10 \%$ to $30 \%$ ) and authigenic carbonate $(10 \%$ to $20 \%)$, while diatom contents range from $15 \%$ to $25 \%$ (Fig. 3, Table 2). The sediment is olive to olive-gray and well bioturbated. Percentages of bulk carbonate average between $25 \%$ and $40 \%$ and reach a maximum of $44.8 \%$ at 20.2 mbsf in Sample 112-682A-3H-1, 84-86 cm (Fig. 4; Table 3). Subunit IB has a minimum $\mathrm{Ca}^{2+}$ content and a maximum $\mathrm{Mg}^{2+} / \mathrm{Ca}^{2+}$ ratio in the pore waters (see "Inorganic Geochemistry," this chapter), suggesting that calcite is the primary mineral phase precipitated at these depths. Petrographically, the authigenic carbonate is primarily anhedral.

\section{Subunit IC}

Subunit IC consists of diatomaceous mud, generally dark olive-gray to black, homogenous to mottled, with common evidence of bioturbation (Fig. 3, Table 2). Diatom contents range from $15 \%$ to $40 \%$ and average $30 \%$. Occasionally, siliceous microfossils are concentrated in pale olive laminae having dia- 
Table 1. Coring summary for Site 682.

\begin{tabular}{|c|c|c|c|c|c|c|}
\hline $\begin{array}{l}\text { Core/ } \\
\text { section }\end{array}$ & $\begin{array}{l}\text { Date } \\
\text { (Nov. } \\
\text { 1986) }\end{array}$ & $\begin{array}{c}\text { Time } \\
\text { (local) }\end{array}$ & $\begin{array}{l}\text { Depth } \\
\text { (mbsf) }\end{array}$ & $\begin{array}{l}\text { Length } \\
\text { cored } \\
\text { (m) }\end{array}$ & $\begin{array}{l}\text { Length } \\
\text { recovered } \\
\text { (m) }\end{array}$ & $\begin{array}{c}\text { Recovery } \\
(\%)\end{array}$ \\
\hline $112-682 \mathrm{~A}-1 \mathrm{H}$ & 9 & 1400 & $0-9.8$ & 9.8 & 9.84 & 100.0 \\
\hline $2 \mathrm{H}$ & 9 & 1500 & $9.8-19.3$ & 9.5 & 9.18 & 96.6 \\
\hline $3 \mathrm{H}$ & 9 & 1550 & $19.3-28.8$ & 9.5 & 8.81 & 92.7 \\
\hline $4 \mathrm{H}$ & 9 & 1700 & $28.8-38.3$ & 9.5 & 8.35 & 87.9 \\
\hline $5 \mathrm{X}$ & 9 & 1850 & $38.3-47.8$ & 9.5 & 1.67 & 17.6 \\
\hline $6 \mathrm{H}$ & 9 & 2000 & $47.8-57.3$ & 9.5 & 7.97 & 83.9 \\
\hline $7 \mathrm{X}$ & 9 & 2205 & $57.3-66.8$ & 9.5 & 2.68 & 28.2 \\
\hline $8 \mathrm{X}$ & 9 & 2340 & $66.8-76.3$ & 9.5 & 0.75 & 7.9 \\
\hline $9 \mathrm{X}$ & 10 & 0150 & $76.3-85.8$ & 9.5 & 1.39 & 14.6 \\
\hline $10 x$ & 10 & 0330 & $85.8-95.3$ & 9.5 & 1.41 & 14.8 \\
\hline $11 x$ & 10 & 0515 & $95.3-104.8$ & 9.5 & 1.41 & 14.8 \\
\hline $12 \mathrm{X}$ & 10 & 0655 & $104.8-114.3$ & 9.5 & 3.90 & 41.0 \\
\hline $13 \mathrm{X}$ & 10 & 0830 & $114.3-123.8$ & 9.5 & 5.72 & 60.2 \\
\hline $14 \mathrm{X}$ & 10 & 1010 & $123.8-133.3$ & 9.5 & 3.00 & 31.6 \\
\hline $15 \mathrm{X}$ & 10 & 1155 & $133.3-142.8$ & 9.5 & 1.79 & 18.8 \\
\hline $16 \mathrm{X}$ & 10 & 1535 & $142.8-152.3$ & 9.5 & 0.59 & 6.2 \\
\hline $17 X$ & 10 & 1735 & $152.3-161.8$ & 9.5 & 1.82 & 19.1 \\
\hline $18 \mathrm{X}$ & 10 & 1930 & $161.8-171.3$ & 9.5 & 2.82 & 29.7 \\
\hline $19 \mathrm{X}$ & 10 & 2115 & $171.3-180.8$ & 9.5 & 0.80 & 8.4 \\
\hline $20 \mathrm{X}$ & 11 & 0005 & $180.8-190.3$ & 9.5 & 2.79 & 29.3 \\
\hline $21 X$ & 11 & 0200 & $190.3-199.8$ & 9.5 & 1.55 & 16.3 \\
\hline $22 \mathrm{X}$ & 11 & 0355 & $199.8-209.3$ & 9.5 & 2.53 & 26.6 \\
\hline $23 \mathrm{X}$ & 11 & 0555 & $209.3-218.8$ & 9.5 & 1.38 & 14.5 \\
\hline $24 \mathrm{X}$ & 11 & 0745 & $218.8-228.3$ & 9.5 & 1.58 & 16.6 \\
\hline $25 \mathrm{X}$ & 11 & 0920 & $228.3-237.8$ & 9.5 & 0.96 & 10.1 \\
\hline $26 x$ & 11 & 1115 & $237.8-247.3$ & 9.5 & 1.11 & 11.7 \\
\hline $27 \mathrm{X}$ & 11 & 1440 & $247.3-256.8$ & 9.5 & 1.46 & 15.3 \\
\hline $28 \mathrm{X}$ & 11 & 1630 & $256.8-266.3$ & 9.5 & 0.58 & 6.1 \\
\hline $29 \mathrm{X}$ & 11 & 1830 & $266.3-275.8$ & 9.5 & 0.86 & 9.1 \\
\hline $30 \mathrm{X}$ & 11 & 2025 & $275.8-285.3$ & 9.5 & 0.05 & 0.5 \\
\hline $31 x$ & 11 & 2235 & $285.3-294.8$ & 9.5 & 0.01 & 0.1 \\
\hline $32 \mathrm{x}$ & 12 & 0030 & $294.8-295.1$ & 0.3 & 0.33 & 110.0 \\
\hline $33 x$ & 12 & 0303 & $295.1-304.6$ & 9.5 & 0.42 & 4.4 \\
\hline $34 \mathrm{X}$ & 12 & 0505 & $304.6-311.2$ & 6.6 & 5.13 & 77.7 \\
\hline $35 x$ & 12 & 0755 & $311.2-320.7$ & 9.5 & 4.28 & 45.0 \\
\hline $36 \mathrm{X}$ & 12 & 1005 & $320.7-330.2$ & 9.5 & 1.79 & 18.8 \\
\hline $37 \mathrm{X}$ & 12 & 1225 & $330.2-339.7$ & 9.5 & 3.75 & 39.5 \\
\hline $38 \mathrm{X}$ & 12 & 1525 & $339.7-349.3$ & 9.6 & 5.07 & 52.8 \\
\hline $39 x$ & 12 & 1800 & $349.3-358.7$ & 9.4 & 3.21 & 34.1 \\
\hline $40 \mathrm{X}$ & 12 & 2020 & $358.7-368.2$ & 9.5 & 5.12 & 53.9 \\
\hline $41 X$ & 12 & 2230 & $368.2-377.7$ & 9.5 & 0.35 & 3.7 \\
\hline $42 x$ & 13 & 0050 & $377.7-387.2$ & 9.5 & 0.42 & 4.4 \\
\hline $43 \mathrm{X}$ & 13 & 0305 & $387.2-396.7$ & 9.5 & 0.02 & 0.2 \\
\hline $44 X$ & 13 & 0645 & $396.7-403.7$ & 7.0 & 0.63 & 9.0 \\
\hline $45 \mathrm{X}$ & 13 & 0935 & $403.7-408.2$ & 4.5 & 0.90 & 20.0 \\
\hline $46 \mathrm{X}$ & 13 & 1350 & $408.2-417.7$ & 9.5 & 2.06 & 21.7 \\
\hline $47 X$ & 13 & 1635 & $417.7-427.2$ & 9.5 & 4.12 & 43.3 \\
\hline $48 \mathrm{X}$ & 13 & 2000 & $427.2-436.7$ & 9.5 & 0.68 & 7.2 \\
\hline
\end{tabular}

tom contents that reach $65 \%$; such laminae may represent periodic blooms of primary producers in the water column. Glauconitic and lithofeldspathic sands occur in isolated or clustered laminae and may be concentrated because of bottom-current winnowing at the seafloor. Glauconite is especially common from 25 to $28 \mathrm{mbsf}, 51$ to $54 \mathrm{mbsf}$, and 76 to $78 \mathrm{mbsf}$. Subunit IC contains the highest values of organic carbon content found at Site 682 , averaging $7 \%$ to $8 \%$ (see "Organic Geochemistry," this chapter).

\section{Subunit ID}

Subunit ID occurs at the base of lithologic Unit I (from 106 to $\sim 114 \mathrm{mbsf}$, even though we did not observe the basal contact) and consists of finely laminated ( 5 to $15 \mathrm{laminae} / \mathrm{cm}$ ) olive-gray to pale olive diatomaceous mud (Fig. 3, Table 2). Little evidence of bioturbation exists, which suggests deposition in oxygen-poor bottom waters. The mechanism of lamination may be attributed to varying inputs of terrigenous and biogenous material. These dark laminae contain approximately $30 \%$ terrigenous silt and $30 \%$ siliceous microfossils, while the light laminae contain approximately $5 \%$ terrigenous silt and up to $60 \%$ siliceous microfossils. Laminae that are anomalously enriched in diatoms occur every 1 to $4 \mathrm{~cm}$. The scale and composition of these laminae resemble those described from the Gulf of California and California Borderland basins, which many think are deposited in annual periodicities and reflect seasonal variations in clastic and biogenic fluxes. The sedimentation rates of organic-rich muds on the Peru margin $(0.7$ to $12.0 \mathrm{~mm} / \mathrm{yr})$ are high enough to produce annual laminations of this type (Suess et al., 1987). The sediments probably originated in an upperslope or outer-shelf basin (associated with either an oxygenminimum zone or behind a structural sill) before remobilization and emplacement.

The laminated strata of Subunit ID have undergone soft-sediment deformation to form a spectacular slump structure (Fig. 7; see also "Structure" section discussed next). Evidence for remobilization includes folding and microfaulting having both compressional and extensional offsets. The upper $\sim 50 \mathrm{~cm}$ exhibits a more fluid deformation similar to a debris flow and may have formed in a zone of intensified shear near the contact with the overlying water column. The basal $70 \mathrm{~cm}$ of Subunit ID is much paler (light gray to olive-gray) and cemented with friable, authigenic dolomite. Dolomite content reaches $80 \%$ in the zone of maximum development, but the cementation front grades into the overlying deposits. Fine sand laminae near the dolomitized zone contain $15 \%$ volcanic glass, $15 \%$ mica, and $25 \%$ dolomite rhombs.

\section{Unit II}

Cores 112-682A-13X-1 through 112-682A-34X, CC; depth, 114-311 mbsf; age, late-middle to late Miocene.

The basic lithology of Unit II consists of diatomaceous mud, olive-gray to dark olive-gray, with homogeneous or bioturbated

Table 2. Lithologic units at Site $\mathbf{6 8 2}$.

\begin{tabular}{|c|c|c|c|}
\hline Unit & Lithology & Core/section & $\begin{array}{l}\text { Depth } \\
\text { (mbsf) }\end{array}$ \\
\hline I & & $112682 \mathrm{~A}-1 \mathrm{H}-1$ to $12 \mathrm{X}, \mathrm{CC}$ & 0 to 114 \\
\hline IA & Diatomaceous mud, foraminifer-bearing. & $1 \mathrm{H}-1$ to $2 \mathrm{H}-3$ & 0 to 14 \\
\hline IB & $\begin{array}{l}\text { Diatomaceous mud, foraminifer- } \\
\text { nannofossil-bearing. }>10 \% \\
\text { authigenic carbonate. }\end{array}$ & $2 \mathrm{H}-4$ to $3 \mathrm{H}-4$ & 14 to 25 \\
\hline IC & Diatomaceous mud. & $3 \mathrm{H}-5$ to $12 \mathrm{X}-2$ & 25 to 106 \\
\hline ID & $\begin{array}{l}\text { Slump deposit of diatomaceous mud, } \\
\text { finely laminated, locally dolomitic. }\end{array}$ & $12 \mathrm{X}-2$ to $12 \mathrm{X}, \mathrm{CC}$ & 106 to 114 \\
\hline II & $\begin{array}{l}\text { Diatomaceous mud. Carbonate-bearing. } \\
\text { Common diagenetic dolomite } \\
\text { horizons. }\end{array}$ & $13 \mathrm{X}-1$ to $34 \mathrm{X}, \mathrm{CC}$ & 114 to 311 \\
\hline III & $\begin{array}{l}\text { Silty mudstone. Massive, fissile, or } \\
\text { brecciated, local carbonate cement. }\end{array}$ & $35 \mathrm{X}-1$ to $44 \mathrm{X}, \mathrm{CC}$ & 311 to 404 \\
\hline IV & $\begin{array}{l}\text { Interbedded mudstone, siltstone, and } \\
\text { sandstone. Pervasive scaley fabric, } \\
\text { local carbonate cement. }\end{array}$ & $45 \mathrm{X}-1$ to $48 \mathrm{X}, \mathrm{CC}$ & 404 to 437 \\
\hline
\end{tabular}




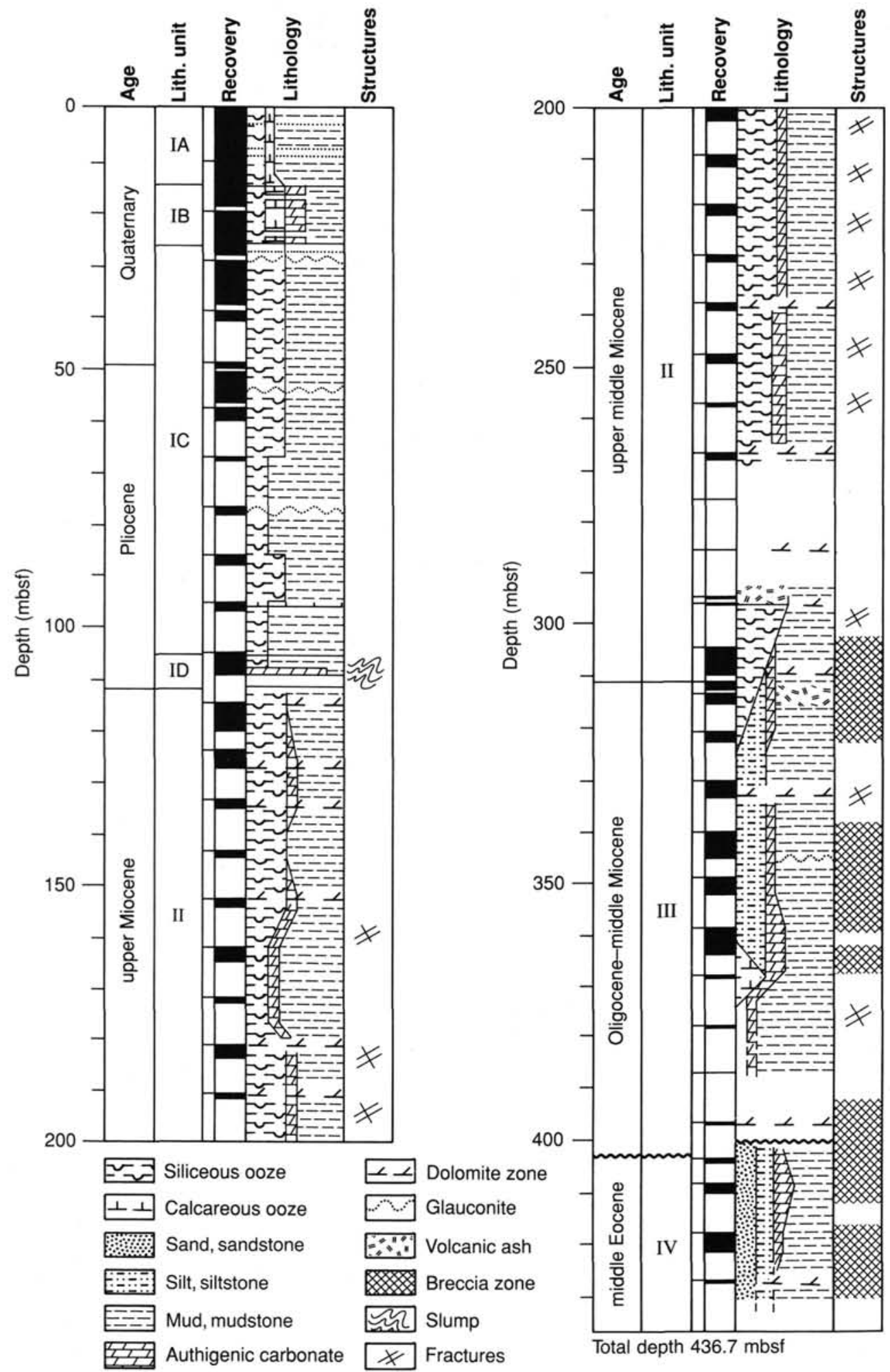

Figure 3. Generalized lithostratigraphic column at Site 682. The width of the lithologic pattern is proportional to its vol\% contribution, as estimated from smear-slide analyses. Core recovery and depth in meters are plotted at left, structural symbols at right.

texture (Fig. 3, Table 2). Diatom contents range from $20 \%$ to $40 \%$, but occasional pale laminae are enriched in siliceous microfossils. Black mudstone containing $40 \%$ to $50 \%$ volcanic ash was encountered at 294-295 mbsf in Core 112-682A-32X near the base of the unit. The ash is magnetite-rich with a scoria- ceous texture and high refractive index, which suggests a basaltic-andesite composition.

Lithologic Unit II may be differentiated from Subunit IC by its lower organic carbon content ( $3 \%$ to $4 \%$; see "Organic Geochemistry" section, this chapter) and higher bulk carbonate con- 
Table 3. Carbonate determinations for Site 682.

\begin{tabular}{|c|c|c|}
\hline $\begin{array}{l}\text { Core/section } \\
\text { interval }(\mathrm{cm})\end{array}$ & $\begin{array}{l}\text { Depth } \\
\text { (mbsf) }\end{array}$ & $\begin{array}{c}\mathrm{CaCO}_{3} \\
(\%)\end{array}$ \\
\hline $112-682 \mathrm{~A}-1 \mathrm{H}-1,50-52$ & 0.50 & 1.17 \\
\hline $1 \mathrm{H}-2,3-4$ & 1.53 & 9.33 \\
\hline $1 \mathrm{H}-2,76-78$ & 2.26 & 10.67 \\
\hline $1 \mathrm{H}-3,76-78$ & 3.76 & 12.75 \\
\hline $1 \mathrm{H}-4,48-50$ & 4.98 & 10.00 \\
\hline $1 \mathrm{H}-5,84-86$ & 6.84 & 10.00 \\
\hline $1 \mathrm{H}-6,10-12$ & 7.60 & 32.58 \\
\hline $1 \mathrm{H}-6,14-16$ & 7.64 & 36.67 \\
\hline $1 \mathrm{H}-6,56-58$ & 8.06 & 0.92 \\
\hline $1 \mathrm{H}-7,49-50$ & 9.49 & 3.17 \\
\hline $2 \mathrm{H}-1,62-64$ & 10.42 & 7.33 \\
\hline $2 \mathrm{H}-3,45-47$ & 13.25 & 1.50 \\
\hline $2 \mathrm{H}-6,51-53$ & 17.81 & 32.33 \\
\hline $3 \mathrm{H}-1,19-20$ & 19.49 & 29.58 \\
\hline $3 \mathrm{H}-1,84-86$ & 20.14 & 44.75 \\
\hline $3 \mathrm{H}-2,55-56$ & 21.35 & 3.83 \\
\hline $3 \mathrm{H}-4,12-13$ & 23.92 & 27.67 \\
\hline $3 \mathrm{H}-4,41-42$ & 24.21 & 28.50 \\
\hline $3 \mathrm{H}-5,58-59$ & 25.88 & 0.50 \\
\hline $3 \mathrm{H}-5,67-69$ & 25.97 & 0.83 \\
\hline $3 \mathrm{H}-5,114-115$ & 26.44 & 1.08 \\
\hline $3 \mathrm{H}-5,128-129$ & 26.58 & 28.08 \\
\hline $3 \mathrm{H}-6,65-67$ & 27.45 & 0.25 \\
\hline $4 \mathrm{H}-1,118-120$ & 29.98 & 1.75 \\
\hline $4 \mathrm{H}-1,127-129$ & 30.07 & 0.25 \\
\hline $4 \mathrm{H}-3,54-56$ & 32.34 & 0.92 \\
\hline $4 \mathrm{H}-3,134-135$ & 33.14 & 2.42 \\
\hline $4 H-4,127-129$ & 34.57 & 0.75 \\
\hline $4 \mathrm{H}-6,39-41$ & 36.69 & 0.58 \\
\hline $5 \mathrm{H}-1,73-75$ & 39.03 & 0.42 \\
\hline $6 \mathrm{H}-1,100-102$ & 48.80 & 0.42 \\
\hline $6 \mathrm{H}-2,102-104$ & 50.32 & 0.75 \\
\hline $6 \mathrm{H}-3,102-104$ & 51.82 & 3.75 \\
\hline $6 \mathrm{H}-4,102-104$ & 53.32 & 0.42 \\
\hline $6 \mathrm{H}-5,102-104$ & 54.82 & 1.75 \\
\hline $7 \mathrm{H}-1,79-81$ & 58.09 & 0.00 \\
\hline $7 \mathrm{H}-2,97-99$ & 59.77 & 1.25 \\
\hline $7 \mathrm{H}-\mathrm{CC}, 16-17$ & 59.86 & 0.58 \\
\hline $8 \mathrm{H}-1,46-48$ & 67.26 & 2.75 \\
\hline $8 \mathrm{H}-\mathrm{CC}, 11-13$ & 67.44 & 3.00 \\
\hline $9 \mathrm{H}-1,37-39$ & 76.67 & 0.92 \\
\hline $9 \mathrm{H}-\mathrm{CC}, 7-9$ & 77.53 & 0.58 \\
\hline $10 X-1,94-96$ & 86.74 & 1.42 \\
\hline $12 X-1,51-53$ & 105.31 & 0.42 \\
\hline $14 \mathrm{X}-\mathrm{CC}, 2-3$ & 126.58 & 3.00 \\
\hline $15 \mathrm{X}-\mathrm{CC}, 9-11$ & 134.78 & 8.33 \\
\hline $16 \mathrm{X}-1,32-33$ & 143.12 & 6.25 \\
\hline $17 \mathrm{X}-1,146-148$ & 153.76 & 9.50 \\
\hline $18 \mathrm{X}-1,112-114$ & 162.92 & 8.08 \\
\hline $18 X-2,84-86$ & 164.14 & 7.58 \\
\hline $20 \mathrm{X}-1,59-61$ & 181.39 & 5.17 \\
\hline $20 X-2,44-46$ & 182.74 & 6.08 \\
\hline $21 X-1,93-94$ & 191.23 & 8.25 \\
\hline $22 \times-2,63-65$ & 201.93 & 4.67 \\
\hline $24 \mathrm{X}-1,117-119$ & 219.97 & 7.08 \\
\hline 25X-CC, $18-19$ & 229.17 & 7.92 \\
\hline $26 \mathrm{X}-\mathrm{CC}, 11-13$ & 238.80 & 7.83 \\
\hline $28 \mathrm{X}-1,6-8$ & 256.86 & 6.42 \\
\hline $29 \mathrm{X}-1,16-18$ & 266.46 & 5.92 \\
\hline $33 \mathrm{X}-1,16-18$ & 295.26 & 3.42 \\
\hline $34 \mathrm{X}-3,30-32$ & 307.90 & 7.42 \\
\hline $35 X-2,97-99$ & 313.67 & 2.83 \\
\hline $36 \mathrm{X}-1,76-78$ & 321.46 & 3.58 \\
\hline $36 \mathrm{X}-1,80-82$ & 321.50 & 3.33 \\
\hline $37 X-2,82-84$ & 332.52 & 7.83 \\
\hline $39 \times-2,6-8$ & 350.86 & 0.92 \\
\hline $40 \times-2,9-11$ & 360.29 & 5.50 \\
\hline $41 X-C C, 10-12$ & 368.30 & 3.17 \\
\hline $42 \mathrm{X}-\mathrm{CC}, 12-14$ & 378.00 & 0.75 \\
\hline $44 X-C C, 10-11$ & 397.13 & 3.74 \\
\hline $45 \mathrm{X}-1,29-30$ & 403.99 & 1.00 \\
\hline $46 \mathrm{X}-1,40-42$ & 408.60 & 11.16 \\
\hline $47 \mathrm{X}-1,51-52$ & 418.21 & 2.75 \\
\hline
\end{tabular}

$\mathrm{H}=$ hydraulic piston; $\mathrm{X}=$ extended-core barrel.

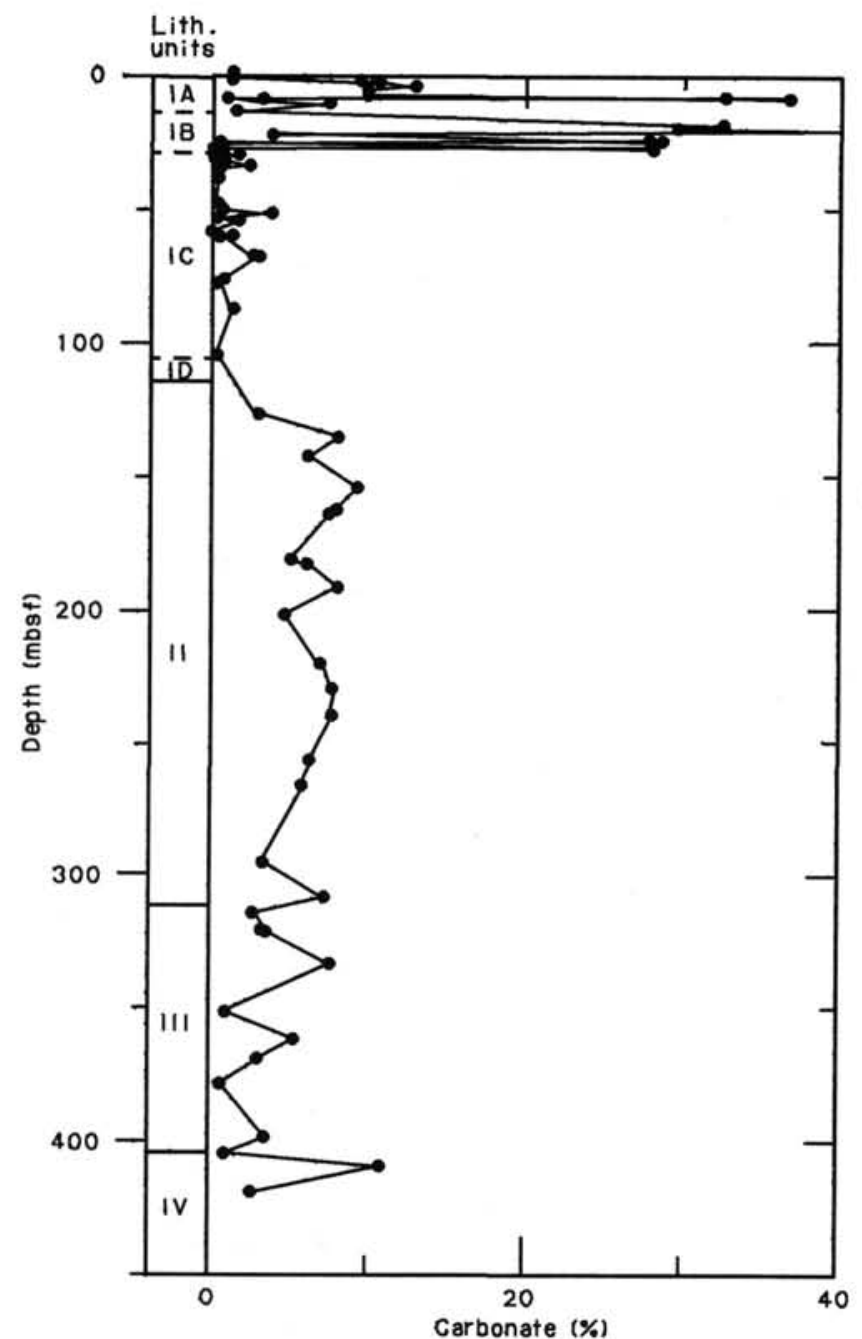

Figure 4. Bulk carbonate content at Site 682. Note moderate values in Unit IA ( $\left(0\right.$ to $\left.13 \% \mathrm{CaCO}_{3}\right)$, extremely high values in Unit IB (25 to $40 \%$ ), extremely low values in Unit IC ( 0 to $4 \%)$, moderate but consistent values in Unit II ( 5 to $10 \%$ ), and erratic, fluctuating values in Units III and IV, which suggest more localized zones of carbonate cementation. See also Table 3 for a listing of results and "Explanatory Notes" (this volume) for a description of analytical methods.

tent (uniformly $5 \%$ to $10 \%$; Fig. 4). Smear-slide estimates of carbonate content range from trace amounts to $15 \%$ and include both biogenic and authigenic components. Clear, rhombohedral dolomite crystals are common, and small bits of foraminifer debris can sometimes be identified. However, much of the carbonate is dispersed within the muds as fine-grained, nonsoluble micrite or dolomicrite. The authigenic carbonate apparently serves as a first-stage, friable cement. Unit II exhibits locally extensive fracturing, which suggests that the sediment is beginning to deform in a brittle manner.

Micritic dolomite zones (generally 2 to $14 \mathrm{~cm}$ thick, olive to pale olive, massive to laminated, and pervasively cemented) are common throughout lithologic Unit II (see "Diagenesis" section, this chapter). Dolomicrite layers are found at 114 (drill breccia), 127, 135, 142 (drill breccia), 153, 171 (drill breccia), 181, 191, 238 (drill breccia), 239, 266, 276 (single-pebble recovery), 285 (rock chips including carbonate-cemented sandstones and mudstones), 294 (drill breccia), and $310 \mathrm{mbsf}$. (Note: drill breccias are accumulations of rock chips at the tops of cores 


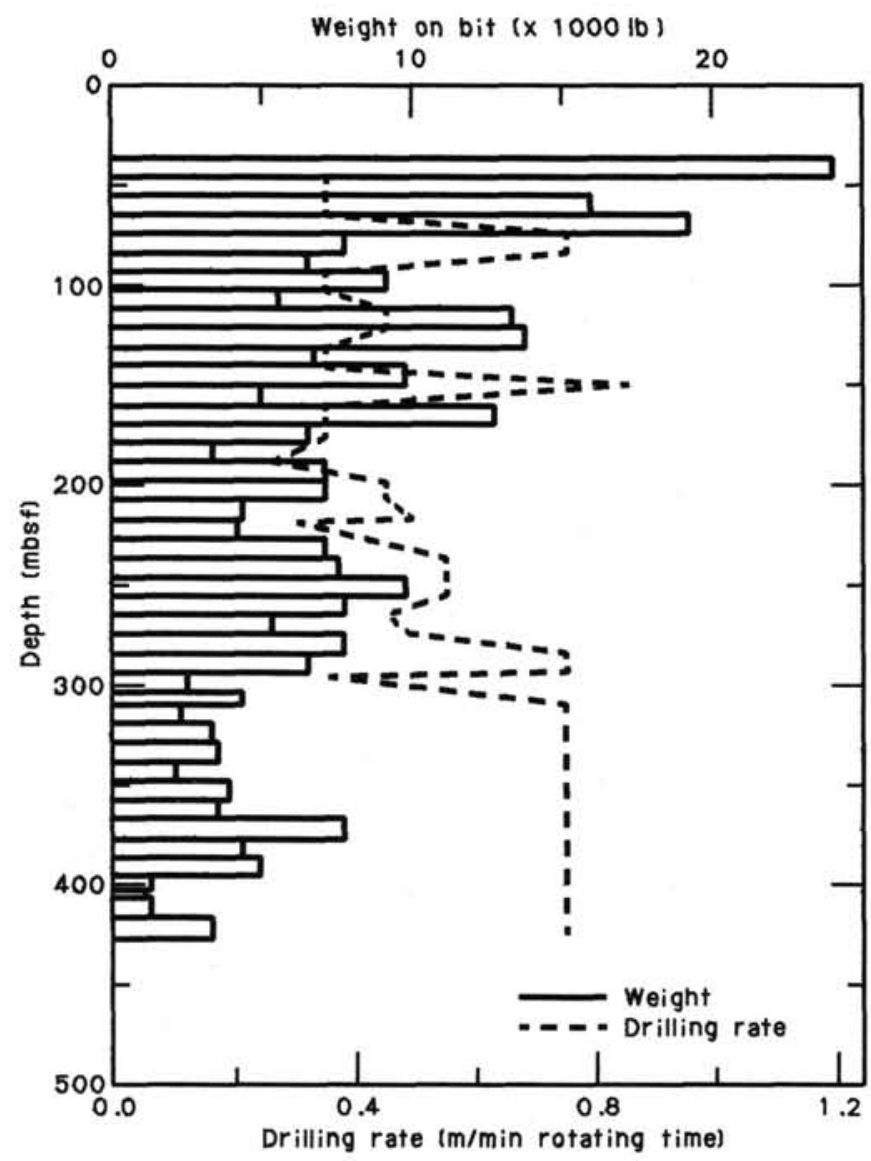

Figure 5. Drilling penetration rates for XCB cores at Site 682. The lithologic boundaries of Units III and IV are based in part on significant decreases in the average penetration rate near 300 and 400 mbsf. The drilling break between Units II and III appears to occur some $15 \mathrm{~m}$ above the lithologic boundary because the bit weight (dashed line) was substantially curtailed just above the interface.

that probably caved in to the bottom of the hole during core retrieval.) Brecciated dolomites at 153, 191, and 285 mbsf experienced an episode of fracture porosity formation and subsequent cement infill.

The contact between lithologic Units I and II corresponds to a potential hiatus in the biostratigraphy. Pliocene sediments apparently overlie the lower part of the upper Miocene (Fig. 3). Unit $\mathrm{I}$ is associated with very high sedimentation rates and abundant evidence of reworked and transported microfossils (see "Biostratigraphy" section, this chapter).

\section{Unit III}

Cores 112-682A-35X-1 through 112-682A-44X, CC; depth, 311-404 mbsf; age, early Oligocene to middle Miocene.

Unit III is generally coarser-grained than Unit II and averages $25 \%$ to $45 \%$ terrigenous components (quartz, feldspar, and rock fragments) and 5\% to $15 \%$ sand. The primary lithology is silty mudstone, dark olive-gray to very dark gray, massive to bioturbated, locally fissile and fractured (Fig. 8). Diatom contents decrease rapidly below the contact with lithologic Unit II and become negligible (trace amounts) below Core 112-682A$36 \mathrm{X}$. Nannofossils are locally abundant and reach $10 \%$ to $30 \%$ in Cores 112-682A-40X and 112-682A-41X. Sand blebs rich in pumiceous volcanic ash with a low refractive index are found in Core 112-682A-35X-3 near 315 mbsf. The distribution of dispersed authigenic carbonate is patchy (Fig. 4) but reaches $25 \%$

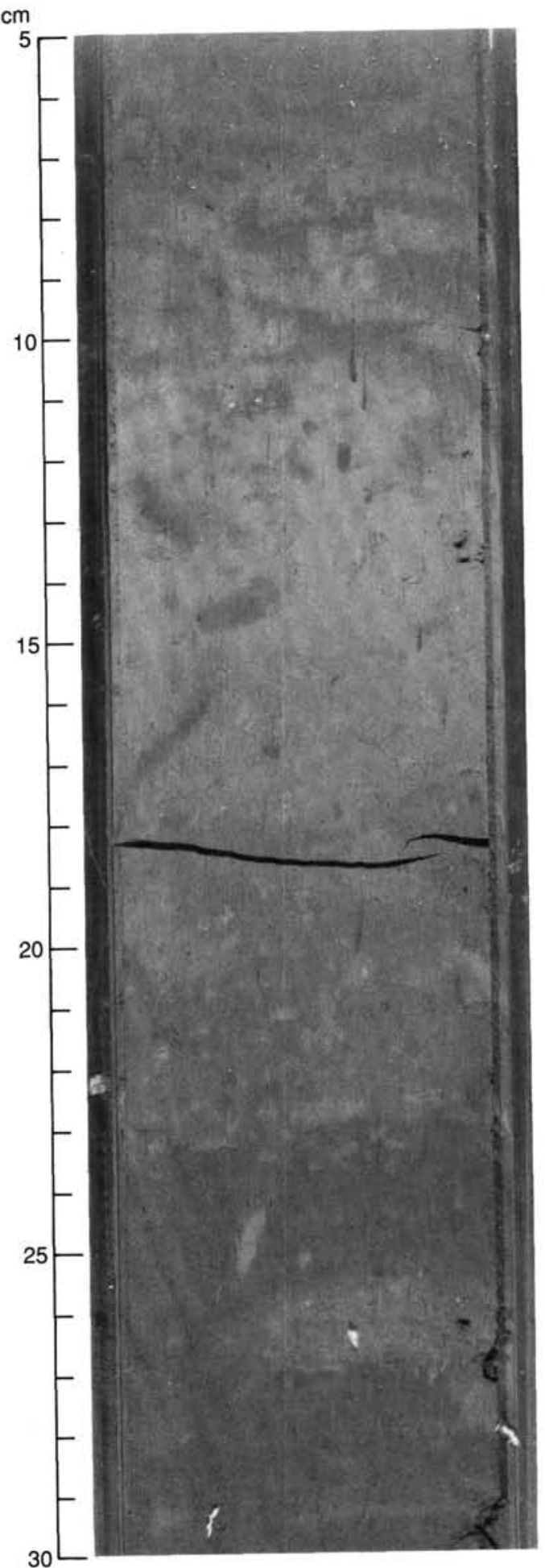

Figure 6. Example of intense bioturbation in the surface diatomaceous muds of Subunit IA (dark) with local interbeds of more calcareous composition (light) (112-682A-1H-6, 5-30 cm).

locally (based on smear-slide analyses), which suggests that cementing fluids tend to follow only a few selected permeability pathways as the sediment becomes more lithified. Dolomicrite zones are found at 315 (brecciated with fracture-fill vein cement), 334, 397 (rock chips include massive and brecciated lithologies and carbonate-cemented mudstones), 398 (brecciated with vein cement), and 404 (drill breccia) mbsf. 

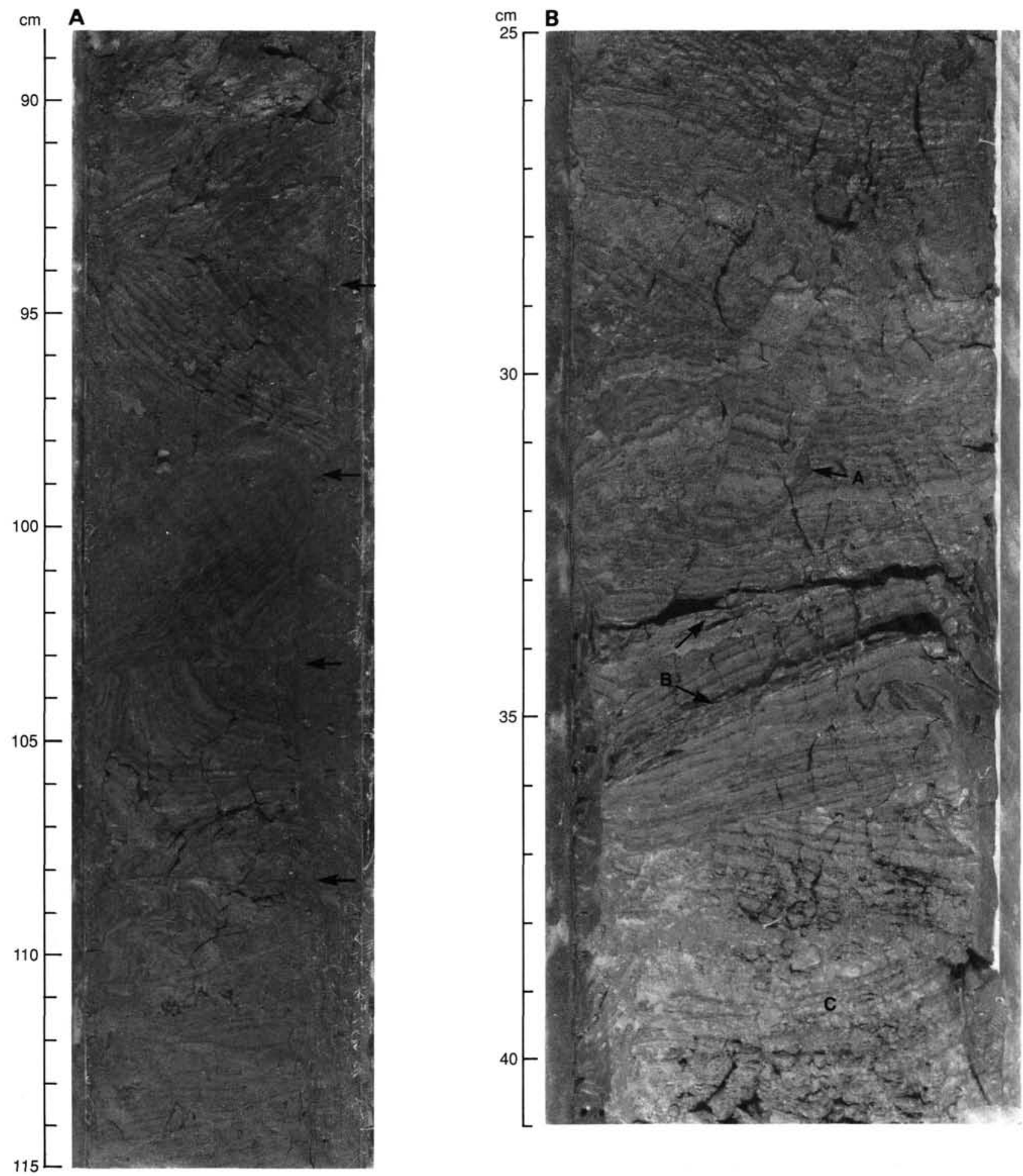

Figure $7 \mathrm{~A})$. (112-682A-12X-2, 88-115 cm); folded and microfaulted, finely laminated strata typical of slump deposits in Unit ID. Arrows indicate breaks between drilling biscuits across which structures have been artificially. B) (112-682A-12X-3, 25-41 cm); finely laminated slump deposits, as above. Note extensional microfaulting (A), fine sand laminae (B), and gradational contact into brittle zone of intense dolomitization (C).

The silty mudstones of lithologic Unit III vary from massive and fissile to extensively fractured and brecciated. Some intervals are obviously fragmented by drilling, although fragmentation may have followed a pre-existing fabric. However, in certain instances a primary breccia fabric may be established where matrix material is clearly distinct from the surrounding drill slurry and where the breccia texture is coherent within well-defined biscuit boundaries (Fig. 9). Such breccias consist of interlocking subangular blocks, which are generally clast-supported and similar in composition to stratigraphically adjacent, nonbrecciated mudstones. The mechanism of brecciation may include tectonic or sedimentary processes (see "Structure" section, this chapter). 


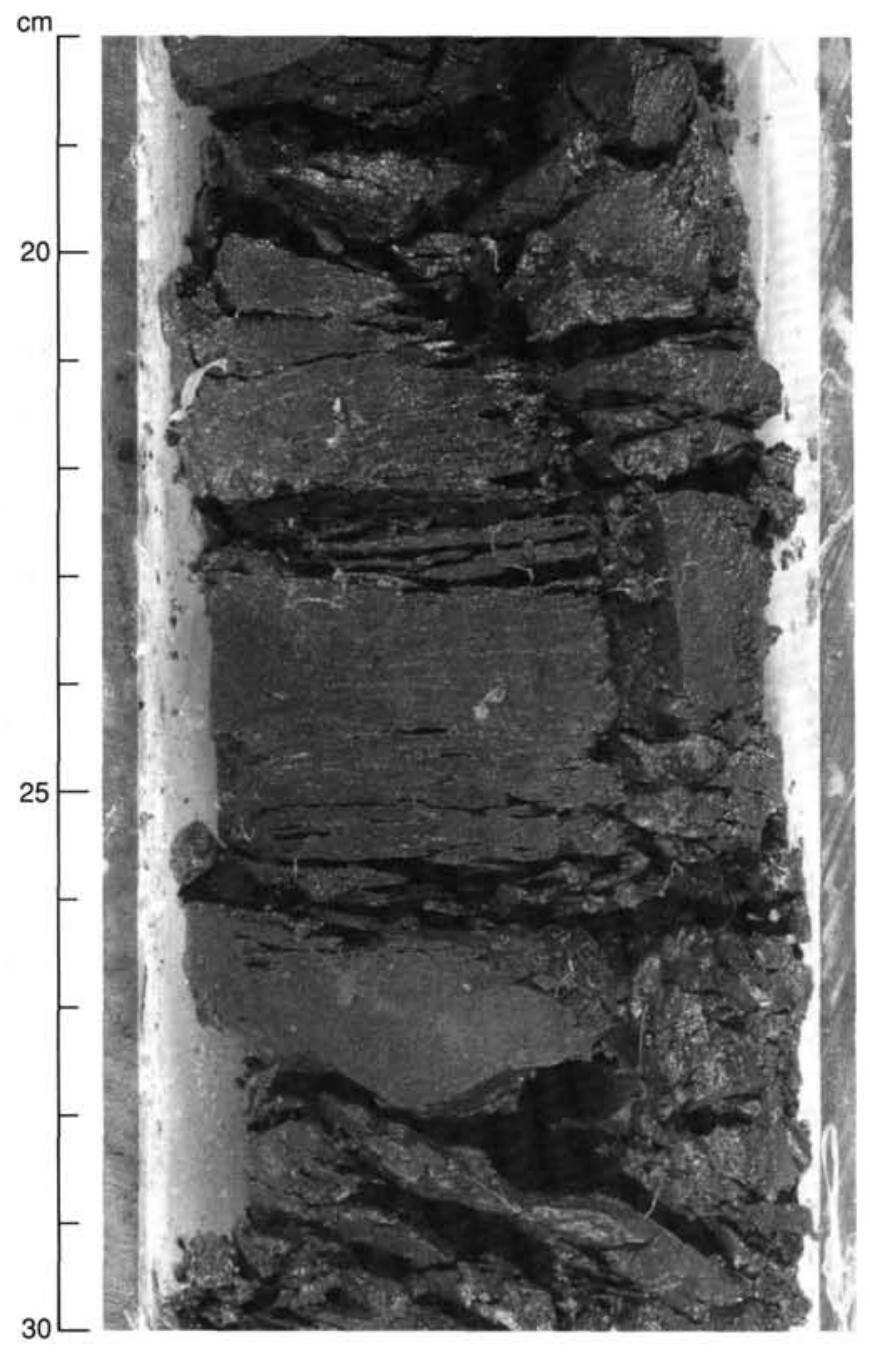

Figure 8. Well-developed fissility in massive mudstones of Unit III (112$682 \mathrm{~A}-38 \mathrm{X}-1,18-30 \mathrm{~cm})$.

The boundary between lithologic Units II and III is located near a major break in the penetration rate of drilling (penetration slows from approximately $0.30 \mathrm{~m} / \mathrm{min}$ in Unit II to 0.15 $\mathrm{m} / \mathrm{min}$ in Unit III; Fig. 5) and a substantial increase in the bulk density of the sediments (from values averaging $1.6 \mathrm{~g} / \mathrm{cm}^{3}$ near the base of Unit II to $2.0 \mathrm{~g} / \mathrm{cm}^{2}$ in Unit III; see "Physical Properties" section, this chapter). The sediments of lithologic Unit III are indurated enough to be classified as mudstones. Biostratigraphic data exhibit a marked decrease in apparent sedimentation rate below this boundary, which may be related in part to increased compaction of the sediment column. The localized occurrence of pervasive scaly fabric in Cores 112-682A$34 \mathrm{X}$ and $112-682 \mathrm{~A}-35 \mathrm{X}$ suggests that a shear zone may have developed along the lithologic interface. In addition, high ethane/ methane ratios near 305 and 320 mbsf suggest that more mature hydrocarbons may be migrating along the interface (see "Organic Geochemistry" section, this chapter).

\section{Unit IV}

Cores 112-682A-45X-1 through 112-682A-48X, CC; depth, 404-437 mbsf; age, middle Eocene.

Unit IV consists of interbedded mudstone (very dark gray to black), siltstone, and lithofeldspathic sandstone (gray) that is bioturbated and pyrite-bearing (Fig. 3; Table 2). Terrigenous components range from $10 \%$ to $60 \%$ and average $30 \%$ in the muds. Authigenic carbonate ranges from $5 \%$ to $30 \%$, which causes pervasive but localized cementation of both the muddy and sandy intervals. We observed a 10 -cm-thick, carbonate-cemented sandstone at 427 mbsf.

Extensive intervals of Unit IV display pervasive scaly fabrics and abundant evidence of plastic and brittle deformation (see "Deformational Structures" section, discussed next). Brecciated zones (primary breccias that were not induced by drilling) contain mudstone blocks that are in turn cut by blocky and scaly fabrics, indicating that deformation predates fragmentation. Sandy lithologies exhibit flow textures and, in places, constitute matrix material. This suggests that the early phases of deformation occurred before cementation at relatively shallow burial depths.

The lithologic discontinuity between Units III and IV corresponds to a biostratigraphic hiatus that encompasses much of late Eocene time (Fig. 3) at the projected depth of a high-amplitude, low-frequency seismic reflector. In addition, a significant break in the drilling penetration rate occurs at 397 mbsf near the lithologic boundary (Fig. 5). We recovered silicified benthic foraminifers of Eocene age from Core 112-682A-44X (see "Biostratigraphy" section, this chapter), which suggests that Unit IV is reworked in the base of overlying Unit III. A laminated, silicified, mudstone clast (the only thing recovered from Core 112$682 \mathrm{~A}-43 \mathrm{X}$ ) contains microfossil molds that are filled in with quartz and chalcedony and that may also represent reworked Eocene material from Unit IV. Anomalous ethane/methane ratios were found near $408 \mathrm{mbsf}$, possibly indicating hydrocarbon migration along the lithologic interface.

\section{Diagenesis}

\section{Phosphates}

With the exception of two thin layers of sand containing foraminifer tests and a few phosphate peloids (Section 112-682A$1 \mathrm{H}-1$ ), no phosphate minerals were identified at Site 682, which lies below the present-day oxygen-minimum zone. While the reasons for this lack of phosphates (for example, compared with their abundance at Sites 679,680 , and 681) remain unclear at this time, we speculate that persistent burrowing at Site 682 prevented the accumulation of dissolved phosphates in these nearsurface sediments and thereby prevented the precipitation of apatite.

\section{Glauconite}

Glauconite occurs as fine-to-medium, sand-sized peloids in trace amounts in all four lithologic units at Site 682. It is most abundant in Subunit IC, where some thin layers contain as much as $40 \%$ glauconite (e.g., Sample $112-682 \mathrm{~A}-6 \mathrm{H}-4,30 \mathrm{~cm}$ ) and appear to record concentrations from current deposition. However, glauconite more typically is present in amounts of $1 \%$ or less as dispersed peloids in diatomaceous muds. The depth of Site $682(3789 \mathrm{~m})$ is well below the outer-shelf/upper-slope depths (about 50 to $500 \mathrm{~m}$ ) considered optimal for the genesis of glauconite (Odin and Matter, 1981). Either glauconite forms at greater depths than previously thought, Site 682 has subsided since the glauconite formed at these outer-shelf/upper-slope depths, or the glauconite was redeposited from shallower water. The last possibility seems the most likely and is in accord with the large numbers of reworked, shallow-water benthic foraminifers found in the sediments at Site 682 (see "Biostratigraphy" section, this chapter).

\section{Authigenic Carbonates}

Precipitation of both authigenic calcite and dolomite has occurred in the sediment column at Site 682, and the distribution of these phases in relation to the pore-water chemistry suggests an interesting and complex pattern of diagenetic development. 

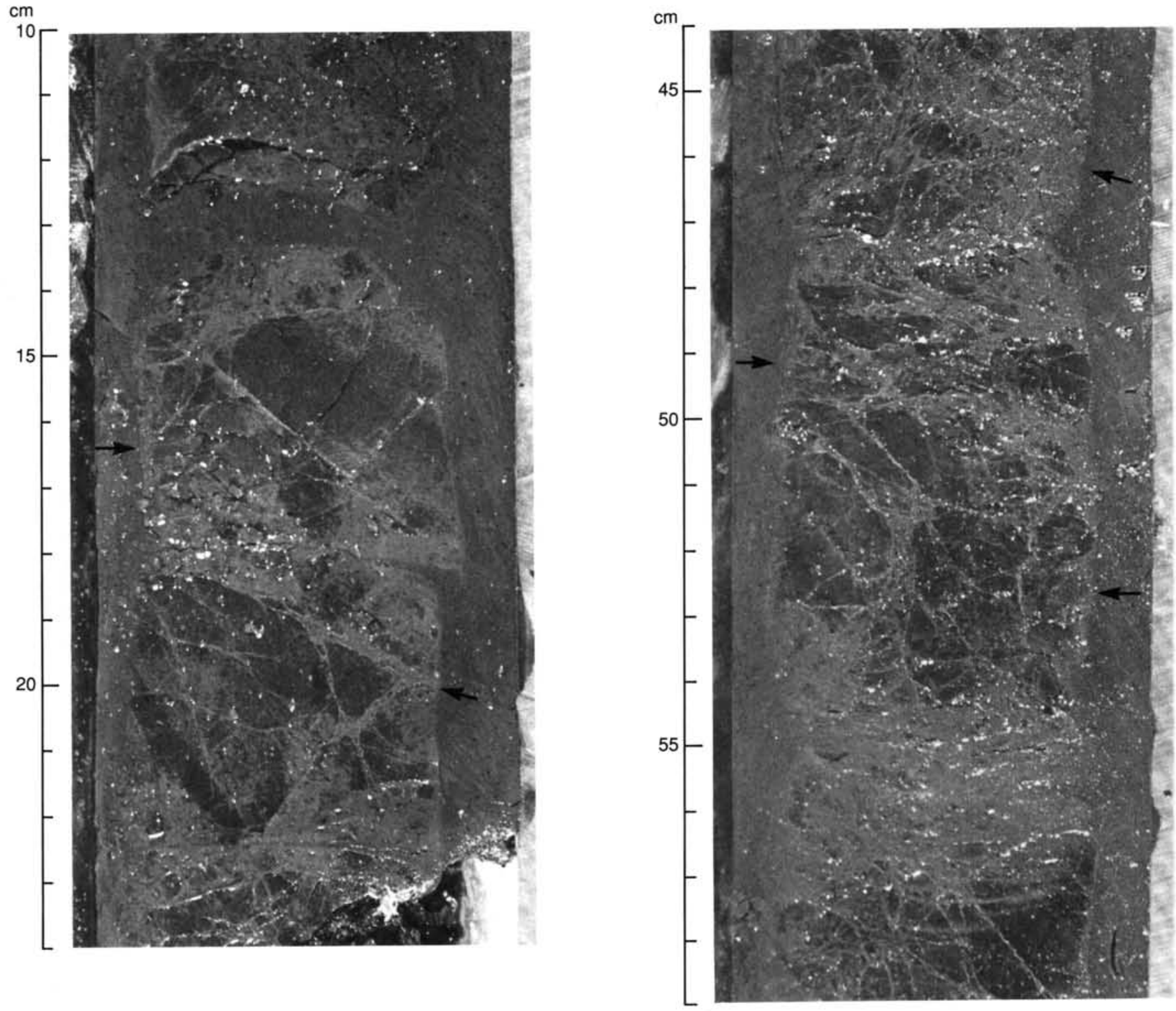

Figure 9. Examples of "primary" breccia fabric cut by randomly oriented fractures (Samples $112-682 \mathrm{~A}-38 \mathrm{X}-3,10-24 \mathrm{~cm}$ and $-38 \mathrm{X}-3,44-59 \mathrm{~cm}$ ). Arrows denote biscuit boundaries within which authentic structure is preserved and matrix material is distinct from drill slurry.

The sediments at Site 682 can be subdivided into three distinct zones on the basis of type and degree of carbonate diagenesis.

Carbonate diagenetic zone 1 extends from the seafloor to about 27 mbsf (Sections 112-682A-1H-1 to 112-682A-3H-5) and encompasses Subunits IA and IB. Total carbonate values in this zone fluctuate widely, ranging from $1 \%$ to $30 \%$ and averaging about $15 \%$ (see Fig. 4, Table 3). Carbonate diagenesis begins virtually at the sediment/water interface, where Sample 112$682 \mathrm{~A}-1 \mathrm{H}-1,0-1 \mathrm{~cm}$, contains $2 \%$ to $3 \%$ authigenic carbonate, including a few euhedral dolomite rhombs. Authigenic carbonate reaches a maximum value (estimated from smear slides) of $25 \%$ in Sample 112-682A-1H-6, $14 \mathrm{~cm}$. Most of this carbonate consists of clay to fine, silt-sized anhedral crystals (probably calcite) with a few euhedral dolomite rhombs invariably present. $\mathrm{X}$-ray diffraction confirms the predominance of calcite in these samples (Fig. 10). As discussed next, pore-water analyses in diagenetic zone 1 show a marked decrease in calcium concentration with depth and an increase in the $\mathrm{Mg}^{2+} / \mathrm{Ca}^{2+}$ ratio, a pattern compatible with the precipitation mainly of calcite.

Carbonate diagenetic zone 2 lies between about 27 and 127 mbsf (Cores 112-682A-4H through 112-682A-14X, CC), includes
Subunits IC and ID, and grades into the uppermost several meters of lithologic Unit II. Beds or nodules of lithified, light brown dolomite and interbedded carbonate-poor diatomaceous mud characterize this zone. Since much of the dolomite was recovered as drilling-breccia fragments and cavings in the tops of core samples, the stratigraphic frequency of dolomite beds remains uncertain. In-situ dolomite beds vary from 2 to $14 \mathrm{~cm}$ thick. The first hard dolomite bed occurs at about $108 \mathrm{mbsf}$ (Sample 112-682A-12X-3, 38-52 cm). We noted unlithified layers rich in authigenic carbonate in several places; for example, core-catcher Samples 112-682A-11X, $17 \mathrm{~cm}$ (60\% micritic carbonate and $10 \%$ dolomite rhombs), $112-682 \mathrm{~A}-12 \mathrm{X}-3,34 \mathrm{~cm}$ ( $25 \%$ dolomite rhombs), and 112-682A-12X, $15 \mathrm{~cm}(80 \%$ dolomite rhombs). Total carbonate values in the diatomaceous muds of zone 2 range between $0 \%$ and $3.75 \%$ (Fig. 4). The calcium in pore waters increases progressively with depth in diagenetic zone 2, while the $\mathrm{Mg}^{2+} / \mathrm{Ca}^{2+}$ ratio decreases, a trend that suggests replacement of calcite by dolomite.

Carbonate diagenetic zone 3 lies between 127 and $436.6 \mathrm{mbsf}$, the total depth of the hole (Sections 112-682A-15X, CC through 112-682A-48X, CC), which encompasses lithologic Units II, III, 


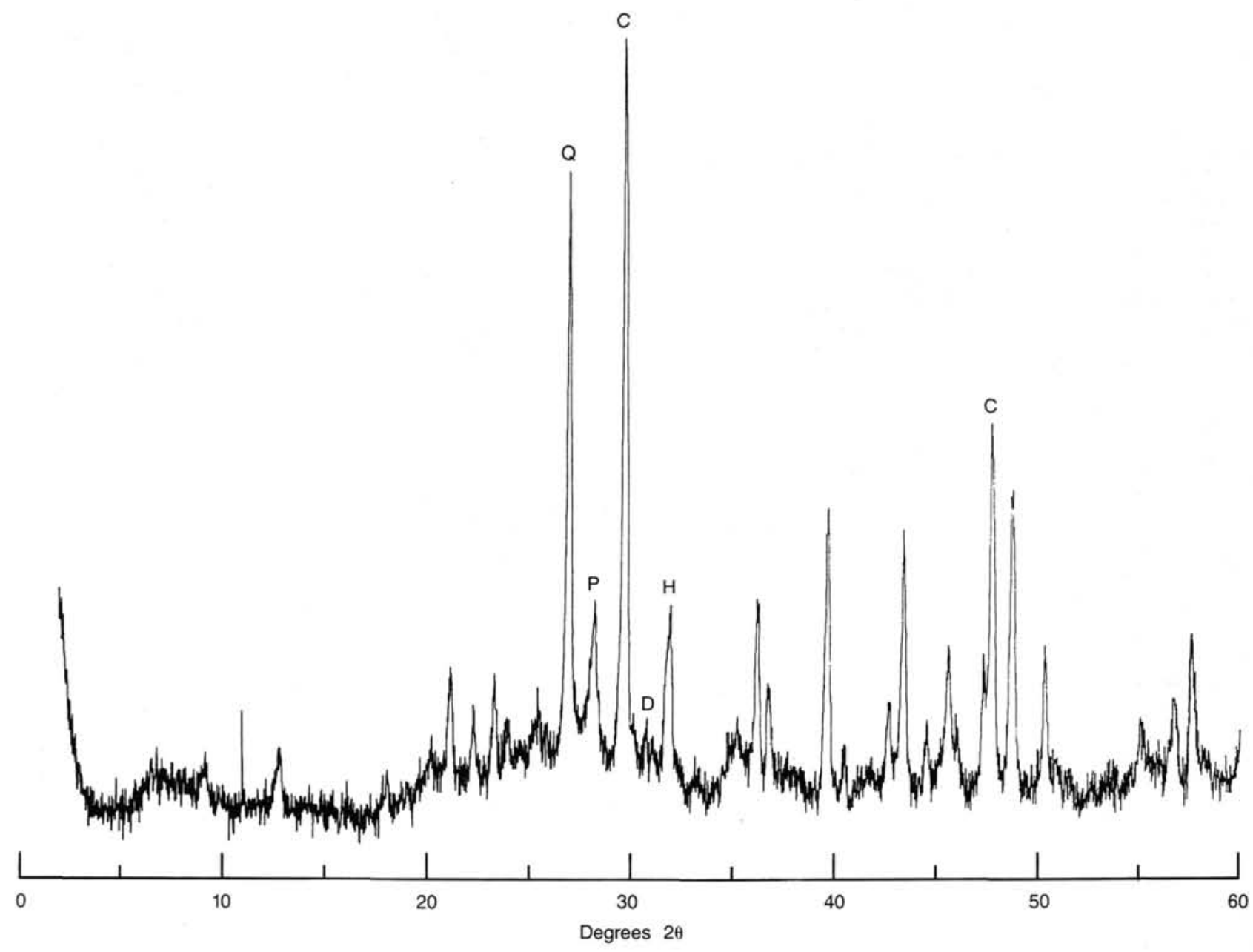

Figure 10. X-ray diffractogram of Sample 112-682A-2H-4, $76 \mathrm{~cm}$, from carbonate diagenetic zone 1. Note the abundance of calcite (peak C), most of which is authigenic. Other peaks are quartz $(\mathrm{Q})$, plagioclase $(\mathrm{P})$, dolomite $(\mathrm{D})$, and halite $(\mathrm{H})$, an artifact.

and IV. Relatively large amounts of both authigenic calcite and dolomite typify this zone, even though the pattern of their development appears erratic and poor core recovery precludes more precise characterization. However, lithified dolomite beds or nodules seemed fairly common and were recovered in Cores $112-682 \mathrm{~A}-15 \mathrm{X}$ through $112-682 \mathrm{~A}-17 \mathrm{X}, 112-682 \mathrm{~A}-19 \mathrm{X}$ through $112-682 \mathrm{~A}-21 \mathrm{X}, 112-682 \mathrm{~A}-26 \mathrm{X}, 112-682 \mathrm{~A}-28 \mathrm{X}$ through $112-$ $682 \mathrm{~A}-35 \mathrm{X}, 112-682 \mathrm{~A}-37 \mathrm{X}$, and 112-682A-39X through 112 $682 \mathrm{~A}-44 \mathrm{X}$.

Several of the dolomite samples in carbonate diagenetic zone 3 have fracture porosity infilled with white cement. Some lithified dolomites fizz gently in dilute $\mathrm{HCl}$ and show a mixture of anhedral crystals and euhedral rhombs in smear slides, suggesting that both calcite and dolomite are present. Carbonate measurements from randomly selected unlithified sediments in zone 3 show carbonate in amounts varying between $3 \%$ and $8 \%$ (Fig. 4). Smear slides of unlithified sediments generally show a mixture of anhedral crystals (probably calcite) and euhedral rhombs (presumably dolomite). A few unlithified beds in the bottom part of diagenetic zone 3 have up to $50 \%$ authigenic carbonate minerals (e.g., Sample 112-682A-46X-1, $135 \mathrm{~cm}$ ), which appear to be a mixture of calcite and dolomite; one unlithified mud has $90 \%$ of what appears to be authigenic calcite (Sample 112$682 \mathrm{~A}-38 \mathrm{X}, \mathrm{CC}[17 \mathrm{~cm}])$. Several samples of these unlithified dolomitic muds show unaltered nannofossils co-existing with dolomite rhombs (e.g., Sample 112-682A-35X, CC [23 cm]), sug- gesting that the calcite content of the primary sediment may localize the genesis of authigenic carbonates.

Pore waters in diagenetic zone 3 generally show increasing amounts of calcium with depth and decreasing $\mathrm{Mg}^{2+} / \mathrm{Ca}^{2+} \mathrm{ra}-$ tios, which suggests that dolomite is the major authigenic phase (see "Inorganic Geochemistry" section, this chapter). A reversal in these trends between 163 and 192 mbsf may indicate the predominance of calcite precipitation, although smear slides from this interval show both authigenic calcite and dolomite.

In summary, carbonate diagenesis at Site 682 shows variable patterns, probably controlled mainly by primary sediment compositions (i.e., abundance of calcareous microfossils) and evolving pore-water chemistries. Compared to Sites 679,680 , and 681 , dolomite forms later and in lesser amounts, but authigenic calcite is much more abundant.

\section{Pyrite}

Pyrite is common in the sediments at Site 682 and occurs in nearly every sample, starting from the interface between these sediments and water (Sample 112-682A-1H-1, 0-1 cm). The most common form of pyrite is framboidal, but it can also be observed replacing the shell walls of microfossils and detrital grains, particularly devitrified volcanic glass. Pyrite is especially conspicuous in lithologic Units III and IV (Cores 112-682A-36X through $112-682 \mathrm{~A}-48 \mathrm{X})$, where it commonly forms $5 \%$ to $15 \%$ of the 
sediment. Authigenic pyrite crystals several millimeters in diameter were found in Sample 112-682A-45X, CC $(8 \mathrm{~cm})$.

\section{Silica and Silicate Diagenesis}

Increasing consolidation of the sediment in the lower part of Hole 682A (beginning with Core 112-682A-35X) corresponds to the absence of diatoms and the alteration of the clay-rich matrix to mudstone having an apparent recrystallization texture. Initially, we suspected the conversion of opal-A diatom frustules to opal-CT, but the X-ray diffractogram of a sample from this interval shows no opal-CT (Fig. 11). However, the diffratogram does suggest the presence of clinoptilolite, a possibility that should be investigated further during shore-based studies.

\section{Structure}

Identification and interpretation of deformational features at Site 682 was handicapped by poor recovery at depth and intense, drilling-related deformation in the XCB cores. Nevertheless, we observed several significant "primary" structures.

\section{Drilling-Induced Structures}

Drilling disturbance was minimal in the APC cores, but with the change to XCB at Core 112-682A-7X, the quality of recovery and of core preservation was substantially reduced. Biscuiting first occurred in the semiconsolidated muds of Section 112$682 \mathrm{~A}-10 \mathrm{X}, \mathrm{CC}$, and was pervasive from this point to total depth. Massive mudstones (encountered in the lower part of the hole) are fractured extensively, usually by high-angle, conjugate fracture systems that resemble those produced in experimental rock- deformation apparatus (see Core 112-682A-37X). Occasionally, these rocks were reduced completely to drilling breccia.

The evolution of the biscuiting process can be reconstructed from the various states of biscuit preservation observed at Site 682. A drilling slurry of disaggregated sediment and circulating water formed around the circumference of the core liner. Initially, the sediment formed partings perpendicular to the core axis at typical spacings of 3 to $10 \mathrm{~cm}$. These partings were invaded progressively by drilling slurry. Both the length and radius of the biscuits were reduced until, depending on the lithology of the material and its degree of consolidation, a drilling slurry of disaggregated, fluid sediment or chips of more indurated material in a slurry matrix was produced. Similar features resulting from rotary coring were described from DSDP Leg 66 cores (Leggett, 1982).

Drilling-induced disaggregation of cores posed particular problems where primary deformation produced a "clast in matrix" or breccia fabric. Drilling slurry invaded the biscuits from the core margins along lines of weakness between clasts, and the matrix became progressively fluid and homogenized with the infiltrating slurry. At this stage of disaggregation, it was difficult to distinguish an original breccia texture from its drilling-induced counterpart.

\section{Deformational Structures}

\section{Slump-Related Structures}

Internal structures related to soft-sediment deformation are especially well developed in lithologic Subunit ID (Sections 112 $682 \mathrm{~A}-12 \mathrm{X}-2$ to $112-682 \mathrm{~A}-12 \mathrm{X}$, CC; Fig. 3) and well preserved

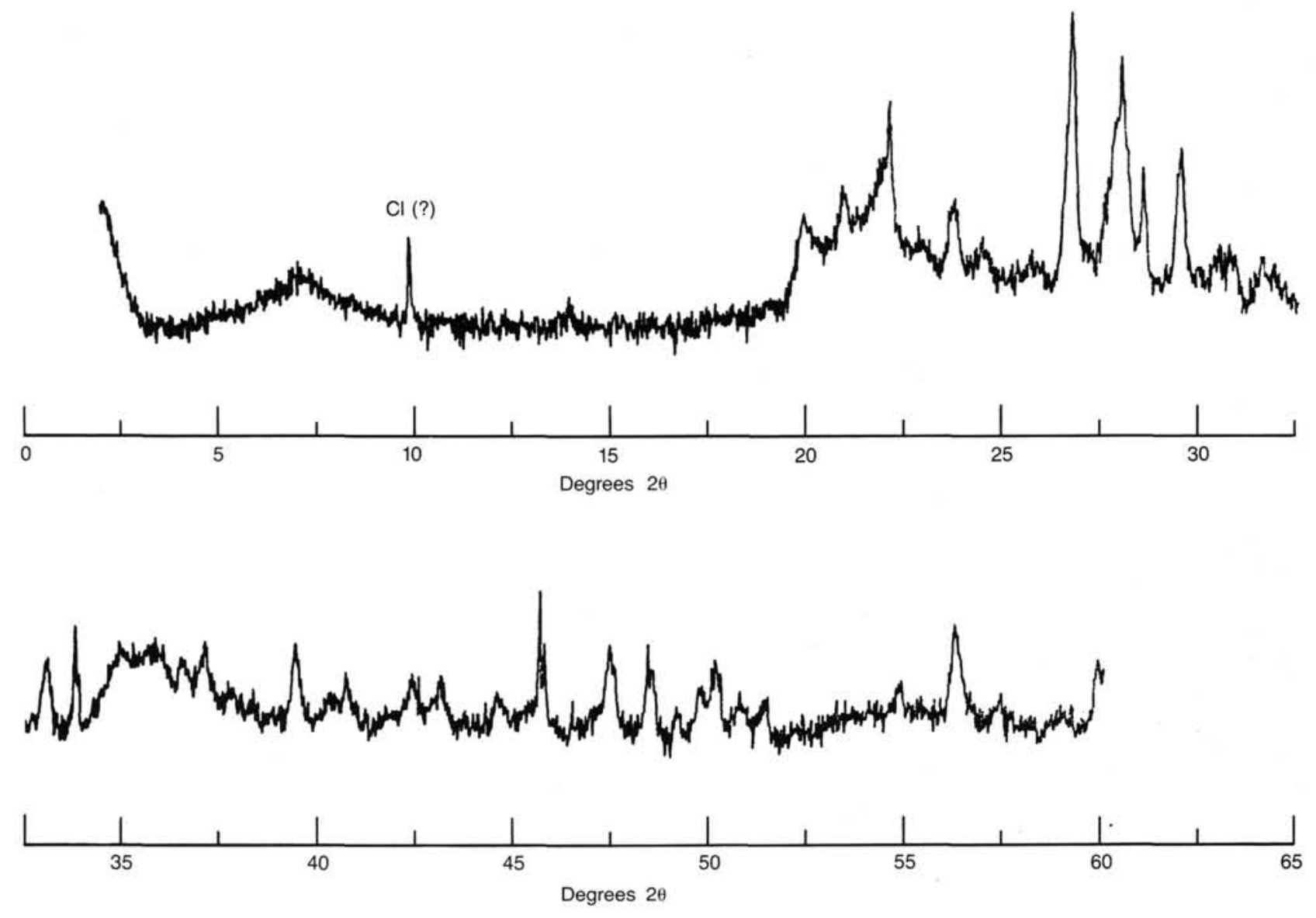

Figure 11. X-ray diffractogram of Sample $112-682 \mathrm{~A}-37 \mathrm{X}-2,54 \mathrm{~cm}$. The presence of clinoptilolite is suggested by the peak at about $10^{\circ} 2 \theta$. 
because of the finely laminated nature of the original lithology. The slump unit is cut by internal discontinuity surfaces; it exhibits tight to isoclinal folding (which is locally complex) and pervasive microfaulting (Figs. 7 and 12). The microfaults are generally extensional, although compressional faults are occasionally associated with fold hinges and discontinuity surfaces (Fig. 12). The association of discontinuity surfaces with compressional microfaults and dissected fold hinges suggests that they originated as thrust surfaces during remobilization. The lack of internal disaggregation suggests that the sediments were partially consolidated at the time of slumping.

Lithologic Unit I. No tectonic structures were observed in the the first five cores of Unit I. An incipient scaly fabric developed in diatomaceous muds beginning with Sample 112-682A$6 \mathrm{X}-3,65 \mathrm{~cm}$, at about $54 \mathrm{mbsf}$. Typically, the anastomosing fabric surfaces are spaced at maximum intervals of 2 to $4 \mathrm{~mm}$. Locally, the fabric surfaces underwent dilation involving simple shear and acted as movement planes to offset burrows.

Detection of microfaults and related deformational features was hampered by the homogeneous, uniform sediment textures present throughout much of Unit I. Excluding the slump-related deformation of Subunit ID, microfaulting was generally absent.

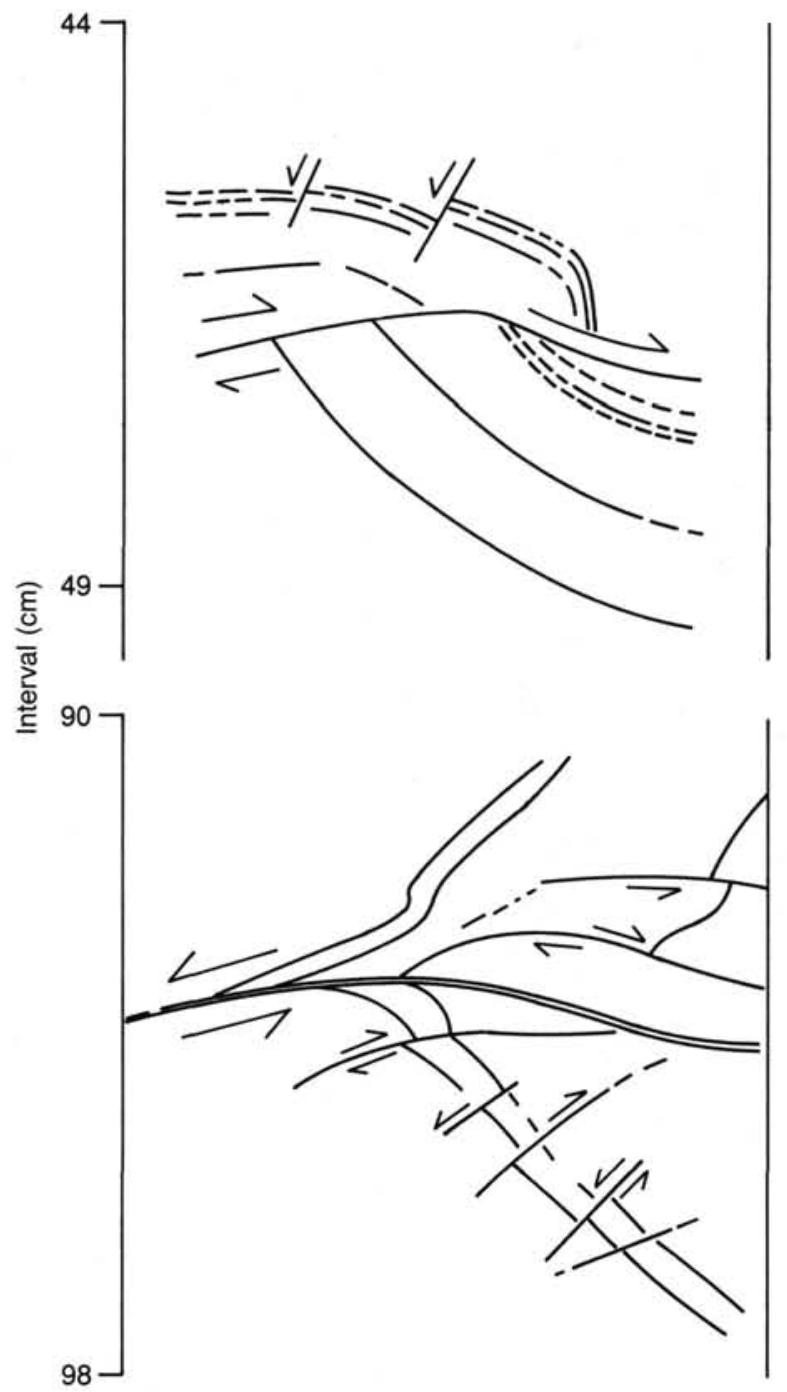

Figure 12. Line drawings of extensional and compressional microfaults associated with folds and movement planes in the slump unit of lithologic Subunit ID, Section 112-682A-12X-2.
Lithologic Unit II. As with Unit I lithologies, the recognition of small-scale deformation features was hampered by the massive nature of the Unit II muds. A scaly fabric (having the form of a jagged parting with no discernable infill) is prominent in Cores 112-682A-21X, 112-682A-22X, and 112-682A-24X. A blocky, uneven, fissility occurs in the massive muds of Cores $112-682 \mathrm{~A}-27 \mathrm{X}$ and $112-682 \mathrm{~A}-28 \mathrm{X}$. With increasing induration in the lower parts of the unit, extensive fracturing becomes common and often pervasive. However, we are not sure whether much of the fracturing observed in lithologic Unit II is a direct result of drilling, or whether drilling has simply exaggerated a pre-existing fabric.

Lithologic Unit III. In Cores 112-682A-34X and 112-682A$35 \mathrm{X}$, much of the sediment within the drilling biscuits displayed chaotic breccia fabrics. Either these biscuits consist of subangular to rounded, silty mudstone clasts in matrix support, or they grade into areas of angular to subangular, interlocking clasts in framework support. Dimensions of the clasts vary in scale from millimeters to centimeters. The breccia fabrics terminate at clearly defined biscuit boundaries, and the matrix is distinct from the drilling slurry in both color and consistency, thereby supporting a primary origin.

A scaly fabric of moderate intensity has developed within the muddy matrix, and some clasts have experienced microboudinage. Bioturbation is relatively common, and some of the "clasts" may result from dissection of burrow infill by movement along fabric surfaces (Fig. 13). Several clasts preserve their original color banding or lamination, and some show internal deformation structures (e.g., extensional microfaults) that do not penetrate the matrix. In some intervals, material from both clasts and matrix appears smeared along movement planes related to the scaly fabric, suggesting that the sediment was relatively unconsolidated when deformed (Fig. 14). Elsewhere, deformation is more brittle and may have affected mudstones at a more advanced state of induration (e.g., Cores 112-682A-35X and 112-682A-38X; Fig. 9).

The breccia fabrics suggest in-situ fragmentation and may be related to fault zones or deep-seated detachment surfaces that are associated with slope failure. The general lack of diverse clast types and of sufficient matrix material necessary for grain support during transport casts doubt on a debris-flow origin.

In the massive mudstones of Cores 112-682A-36X to 112 $682 \mathrm{~A}-39 \mathrm{X}$, a millimeter-sized, anastomosing fissility was ob-

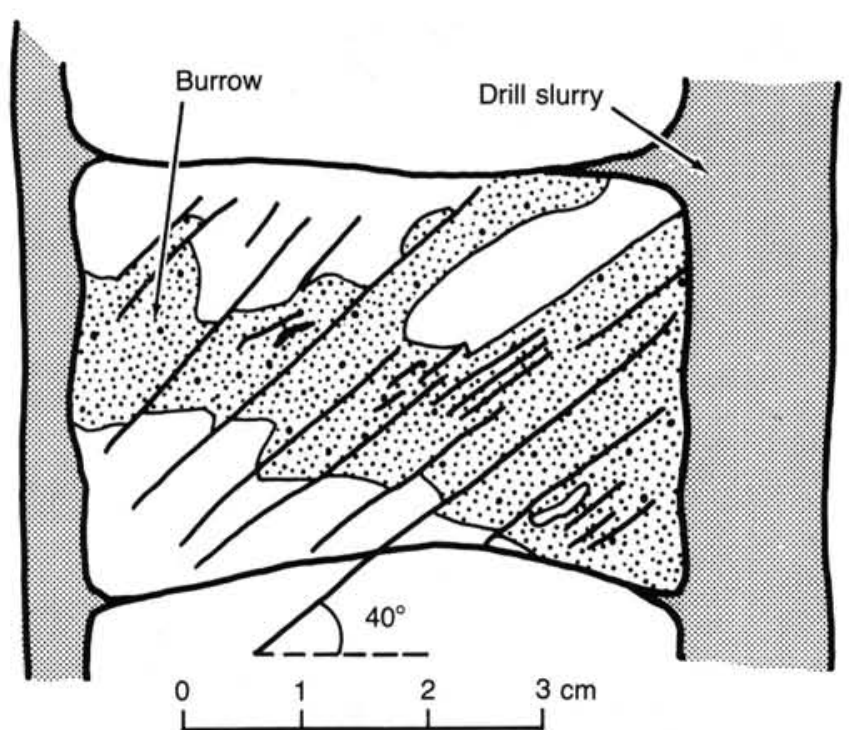

Figure 13. Diagram of a burrow dissected by scaly fabric near $305 \mathrm{mbsf}$ in Section 112-682A-34X-1. 


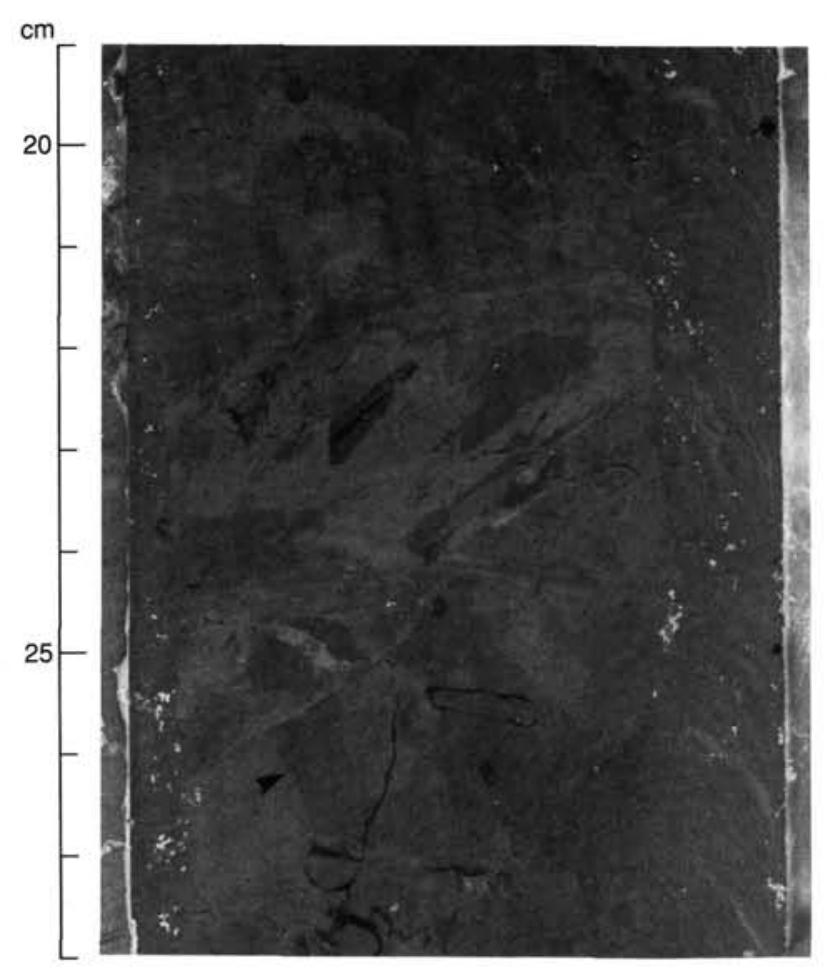

Figure 14. Deformation near $310 \mathrm{mbsf}$ showing dissection of burrow (arrow) by movement surfaces and smearing out of clast material into matrix (Sample 112-682A-34X-4, 19-28 cm).

served (Fig. 8). Drilling slurry pervades some partings, and clearly the fissility was exploited during the biscuiting process. Localized, high-angle, conjugate fractures that are symmetrical about the core axis also developed in this interval and appear to be drilling-induced. Alternatively, such a fabric could be produced within a tensional stress regime.

Lithologic Unit IV. Cores 112-682A-45X to $112-682 \mathrm{~A}-48 \mathrm{X}$ constituted the most indurated sediment recovered at Site 682 , excluding the isolated chert pebble of Core 112-682A-43X and the cemented dolomite zones. This interval contains extended and boudinaged siltstone and mudstone layers in a muddy matrix. A strong, pervasive scaly fabric that wraps around clasts is present throughout. The fabric is partly defined by a subparallel alignment of the long axes of elongate clasts, many of which originate from the extension of siltstone and mudstone layers. Most of these clasts have elongated tails trailing off into the adjacent matrix and have apparently undergone boudinage by extreme necking. This suggests an early origin for much of the stretching when little ductility contrast still existed between the various components.

The sandy lithologies generally occur as smeared-out blebs and pockets distributed in the matrix. Features such as this and much of the boudinage observed suggest deformation early in the post-depositional period beneath a relatively thin overburden. However, some extended thin beds of dark gray siltstone are barrel-shaped and show internal brittle fractures, which suggests that they were partly lithified or cemented at the time of deformation (Fig. 15).

Preliminary shipboard examination of this fabric using the scanning electron microscope shows that this spacing is from 0.4 to $1 \mathrm{~mm}$ (Fig. 16). However, a penetrative fabric is not present within the cleavage domains. The lack of a penetrative fabric and the apparent absence of recrystallization supports a "flow" origin for the fabric; i.e., it is a classical movement-related scaly cleavage.

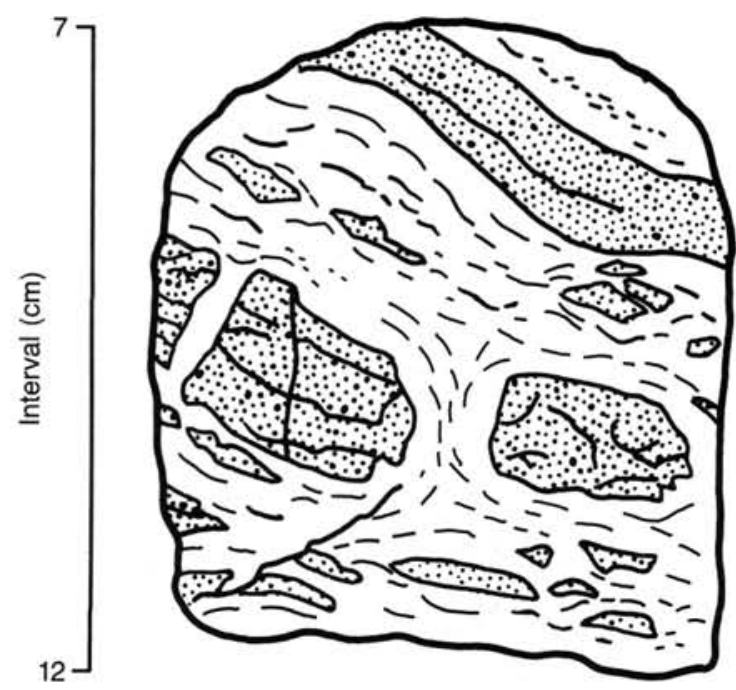

Figure 15. Detail of extensional fabric in Sample 112-682A-46X-CC, 7$12 \mathrm{~cm}$, near $410 \mathrm{mbsf}$, showing boudinage by both extreme necking and early brittle failure (barrel shapes).

Development of a microscopically nonpenetrative scaly fabric such as this requires some component of simple shear as well as extension during deformation. The geometry and pervasive nature of the fabric suggest the presence of significant overburden during deformation. Currently, we cannot determine whether these fabrics resulted from deformation within compressional or extensional regimes or from deep-seated gravitational processes acting on slope sediments.

\section{BIOSTRATIGRAPHY}

A single hole was drilled at Site 682 in mostly hemipelagic slope deposits of Quaternary to Eocene age. The hole was terminated at 436.7 mbsf in middle Eocene mudstones. With the exception of diatoms, microfossils were not abundant throughout the Holocene to lower Miocene section recovered. However, the variety of fossil groups increased in the lower Miocene, while diatoms decreased.

Preliminary information about occurrences, diversity, and abundance of fossil groups is contained in the individual microfossil subchapters. Their occurrences are summarized in Figure 17.

The sedimentation rate is approximately $25 \mathrm{~m} / \mathrm{m}$.y. in the upper part of the hole to Core 112-682A-27X (in the middle Miocene to Holocene interval). In the lower part of the middle Miocene and in the lower Miocene the sedimentation rate decreases to $10 \mathrm{~m} / \mathrm{m}$.y. We noted a further decline in the Eocene but cannot evaluate it because of sparse data.

\section{Diatoms}

Diatoms are abundant and generally well preserved in Cores $112-682 \mathrm{~A}-1 \mathrm{H}$ through $112-682 \mathrm{~A}-34 \mathrm{X}$. The location of this site seaward of the nearshore coastal upwelling areas permitted invasion of temperate and equatorial oceanic floral elements during much of the Cenozoic. Despite the distant offshore location, the diatom floras at this site still record the distal trail of the coastal upwelling phenomenon. The presence of equatorial and temperate elements allowed us to recognize some of Barron's (1985) diatom zones, which were defined during DSDP Leg 85 and which were directly correlated to the paleomagnetic reversal stratigraphy. Rare diatom assemblages having poor preservation occurred in Sections 112-682A-35X, CC through 112682A-38X, CC. The absence of Rhaphidodiscus marylandicus 


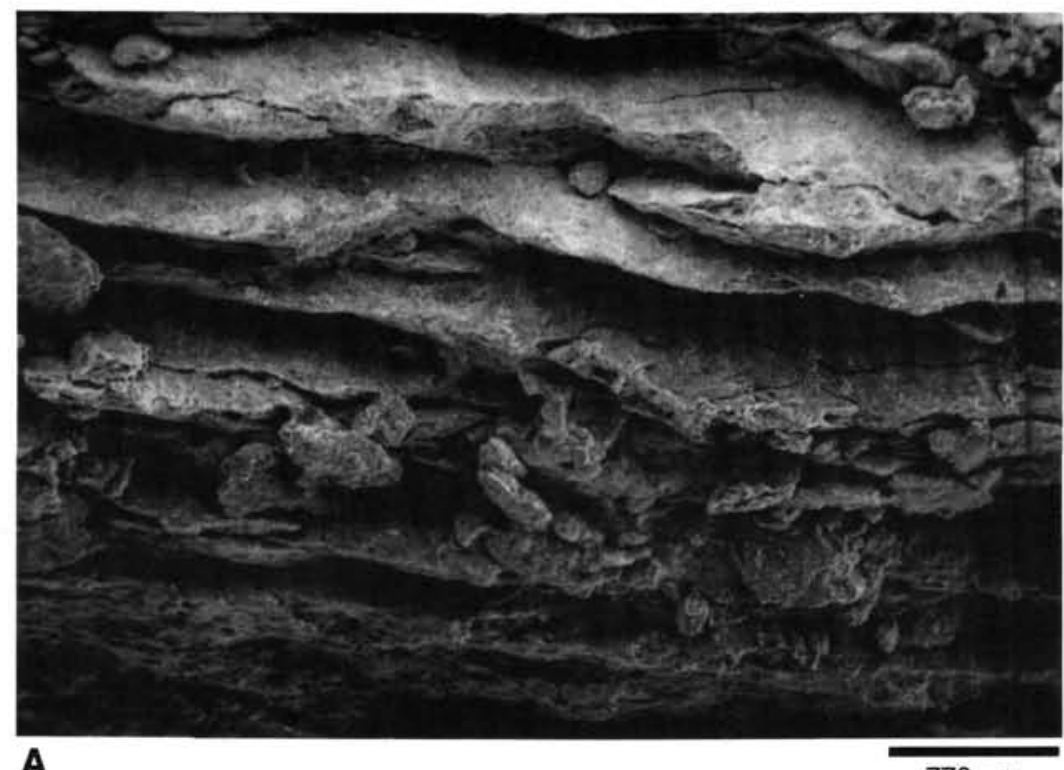

A

$770 \mu \mathrm{m}$

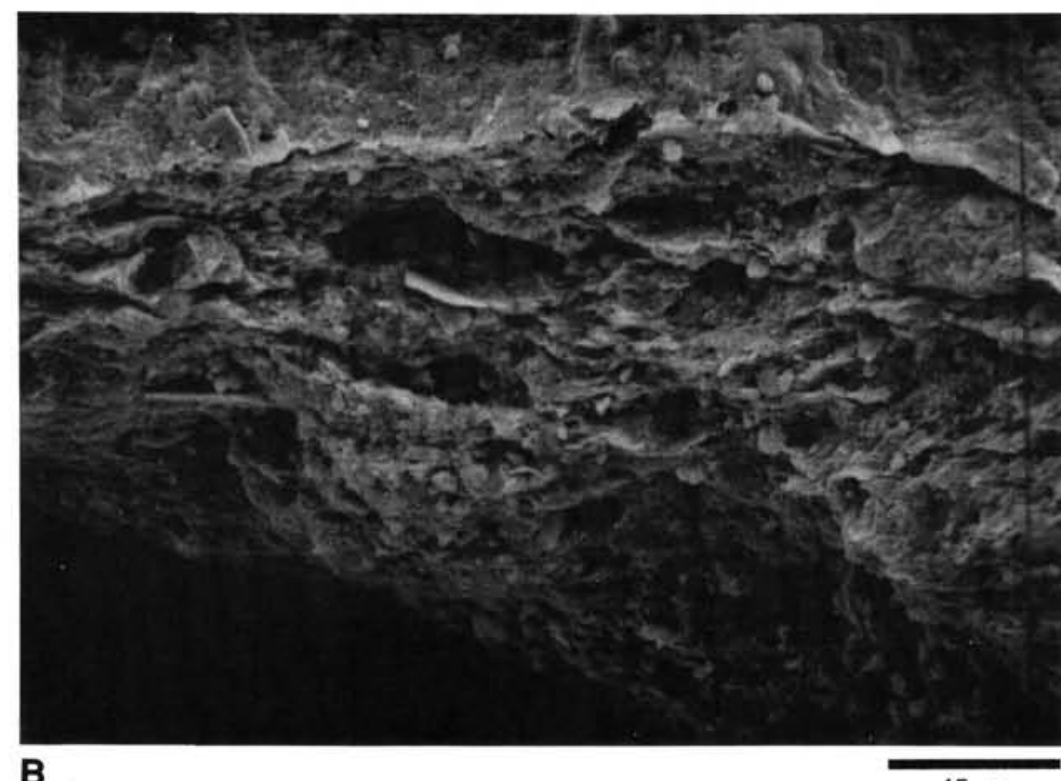

B

$45 \mu \mathrm{m}$

Figure 16. SEM photos of scaly fabric in Sample 112-682A-46X-1, $119 \mathrm{~cm}$ near $409 \mathrm{mbsf}$ in Unit IV. (A) General morphology of scaly fabric. (B) Detail of broken cleavage surface (top-middle-right of upper photo) showing fabric to be microscopically nonpenetrative.

in Section 112-682A-36X, CC places this sample in the uppermost Oligocene. Despite poor diatom preservation, the middle portions containing Rhaphidodiscus marylandicus should have been preserved and would be recognized if present.

Sponge spicules, silicoflagellates, freshwater diatoms, displaced shallow-water benthic diatoms, ebridians, and phytoliths did occur occasionally throughout the section, even though no interval in particular was enriched in these siliceous remnants. Replacement of opaline diatom structures with pyrite (which adversely affects opal preservation) was obvious in Section 112682A-32X, CC.

The sample obtained from acid leaching of dolomite in Section 112-682A-37, CC represented drilling contamination from the Denticulopsis nicobarica Zones recovered in Section 112682A-34X, CC.

Disturbance of upper Miocene sections occurred at this site over the identical time interval as at Hole 679A. Some of the well-established, well-dated late Miocene zones of the equatorial Pacific (Barron, 1985) were missing and were replaced by middle Miocene and/or late Miocene zones. This disturbance falls into the time span of the Messinian Event (Hsü et al., 1977) and coincides with a worldwide decrease in sea levels during the latest Miocene.

We recognized several intervals of colder-water diatom assemblages. The most pronounced one (between 13 and $14.2 \mathrm{Ma}$; Fig. 17) was also recognized by Barron (1985), Woodruff et al. 


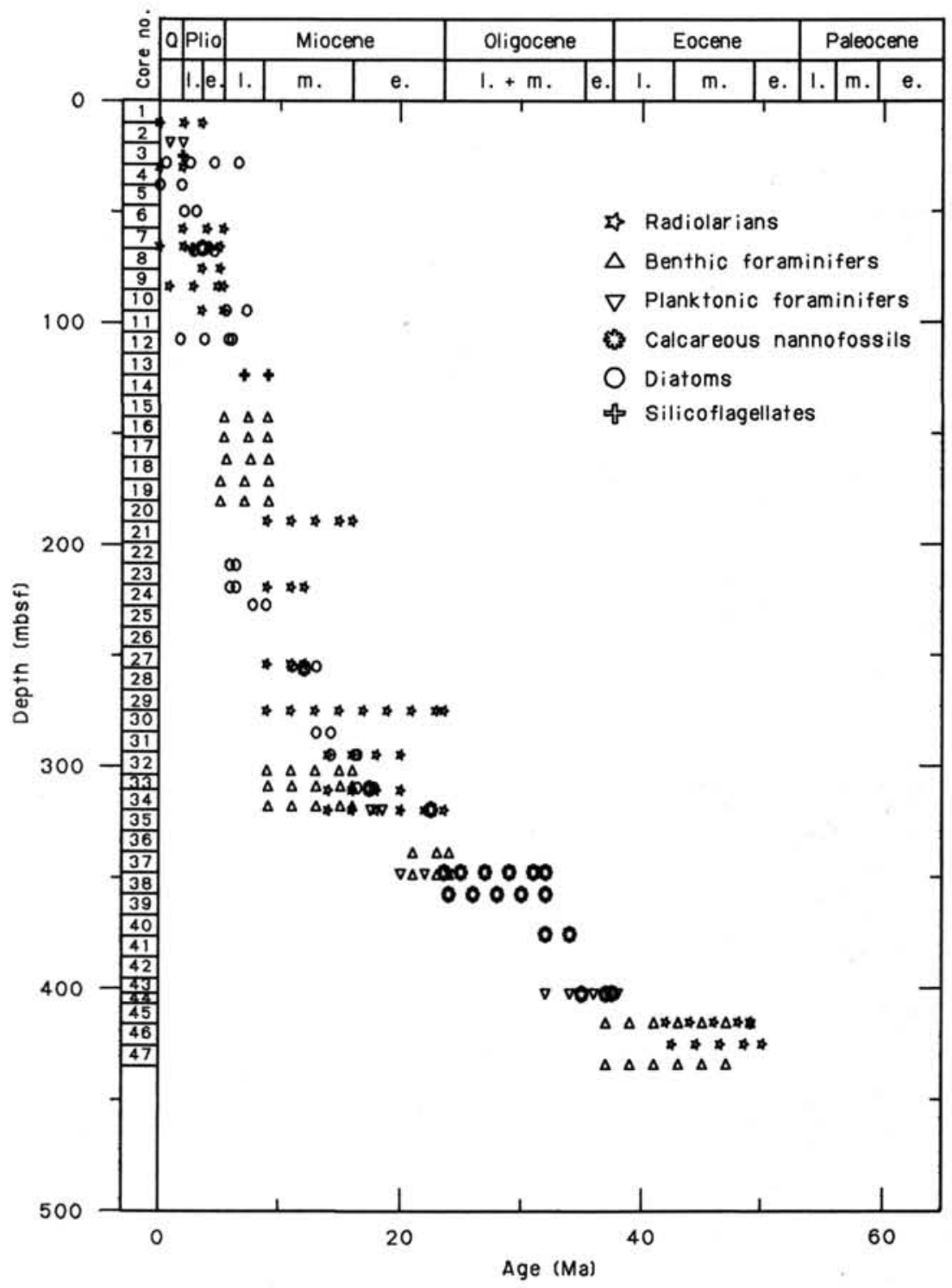

Figure 17. Occurrences and ranges of microfossils at Site 682.

(1981), and Keller and Barron (1983) in equatorial and North Pacific sections. This middle Miocene cooling was reflected at Site 682 by abundant Coscinodiscus marginatus. It is related to the massive formation of an Antarctic ice sheet (Shackleton and Kennett, 1975).

High primary production of opal started at Site 682 during the early Miocene around $18 \mathrm{Ma}$ and continued through the Holocene. This production was preceded by a time span of around $6 \mathrm{~m} . \mathrm{y}$. when opal production and preservation were limited. Short-term variations did occur, but the general aspect of the diatom flora did not change significantly (Fig. 17). Thalassionema nitzschioides, Thalassiothrix longissima, Delphineis spp., Chaetoceros spores, Thalassiosira spp., and their fossil counterparts form the major floral components.

We identified the following diatom zones on the basis of the presence of primary zonal markers and/or secondary markers, including Pacific-wide acme zones:

1. The Pseudoeunotia doliolus Zone occurred in Cores 112 $682 \mathrm{~A}-1 \mathrm{H}$ through $112-682 \mathrm{~A}-4 \mathrm{H}$. Mesocena quadrangula occurred in this zone in Section 112-682A-3H, CC; reworking was common in this interval.

2. The Rhizosolenia praebergonii Zone was found in Sections 112-682A-5X, CC through 112-682A-6H, CC. Sections $112-682 \mathrm{~A}-7 \mathrm{X}, \mathrm{CC}$ through 112-682A-9X, CC could not be assigned to any existing zonal schemes.

3. The Thalassiosira convexa Zone was found in Section 112-682A-10X, CC.

4. The last common occurrence of Denticula hustedtii was recognized in Section 112-682A-11X, CC. Thalassiosira antiqua occurred only in Sample 112-682A-12X-2, 10-46 cm. The acme zone of Rouxia californica occurred in Section 112-682A-14X, $\mathrm{CC}$, while the last occurrence of Rhizosolenia miocenica was detected in Section 112-682A-17X, CC. The last occurrence of Thalassiosira praeconvexa was noted in Section 112-682A-23X, CC, and the last occurrence of Thalassiosira yabei was found in Section 112-682A-25X, CC.

5. The Coscinodiscus gigas var. diorama Zone occurred in Sections 112-682A-27X, CC through 112-682A-28X, CC.

6. The Coscinodiscus lewisianus Zone occurred in Section 112-682A-30X, CC. 
7. The Cestodiscus peplum Zone, here tentatively defined by the presence of Nitzschia maleinterpretaria, was present in Section 112-682A-31X, CC. Denticula hustedtii also first occurred in this sample.

8. The Denticulopsis nicobarica Zone occurred in Section 112-682A-34X, CC.

The sedimentation-rate curve (Fig. 18) is based on the above zonal assignments along with direct correlation to the magnetic reversal record (Barron, 1985); sedimentation rates vary from 26 $\mathrm{m} / \mathrm{m}$.y. over the interval 0 to $60 \mathrm{mbsf}$ to $22 \mathrm{~m} / \mathrm{m}$.y. over the interval 60 to $120 \mathrm{mbsf}$ to $10 \mathrm{~m} / \mathrm{m}$.y. over the interval 220 to 310 mbsf. Two short hiatuses may exist at $120 \mathrm{mbsf}(\mathrm{H}-1)$ and at 240 mbsf (H-2) and may confine the late Miocene slump deposits between 6 and $9 \mathrm{Ma}$. We assigned no date to the "chaotic" interval between 120 to 220 mbsf.

\section{Silicoflagellates}

All core-catcher and some additional samples were studied for silicoflagellates. Preliminary data showed that silicoflagellates are present from the top of the hole down to Core 112-682A-37X, covering the whole Neogene and Quaternary, although they seldom occur in the lowest Miocene because of the low opal content of the sediments.

The silicoflagellate zonation of the Southwest Pacific (Locker and Martini, 1986) was used for this site with only minor changes in the late Miocene. These changes were necessary because neither the Neonaviculopsis group nor Mesocena circulus or Mesocena diodon were found, which were used to assign silicoflagellate zonations in this interval elsewhere.

The lowest occurrence of Distephanus bioctonarius bioctonarius was found in Sample 112-682A-3H-3, 69-70 cm. Mesocena quadrangula is present in Core 112-682A-3H and in Section 112-682A-4H-4. In Sections 112-682A-4H, CC, and 112-682A$7 \mathrm{H}, \mathrm{CC}$, Distephanus boliviensis is present, which indicates an interval in the middle Pliocene in accordance with calcareousnannoplankton data at this level and also a hiatus in the lowest part of Core 112-682A-4H. The change from frequent Dictyocha messanensis stapedia (with vertical apical bar) to frequent Dictyocha varia (with horizontal apical bar), which we found

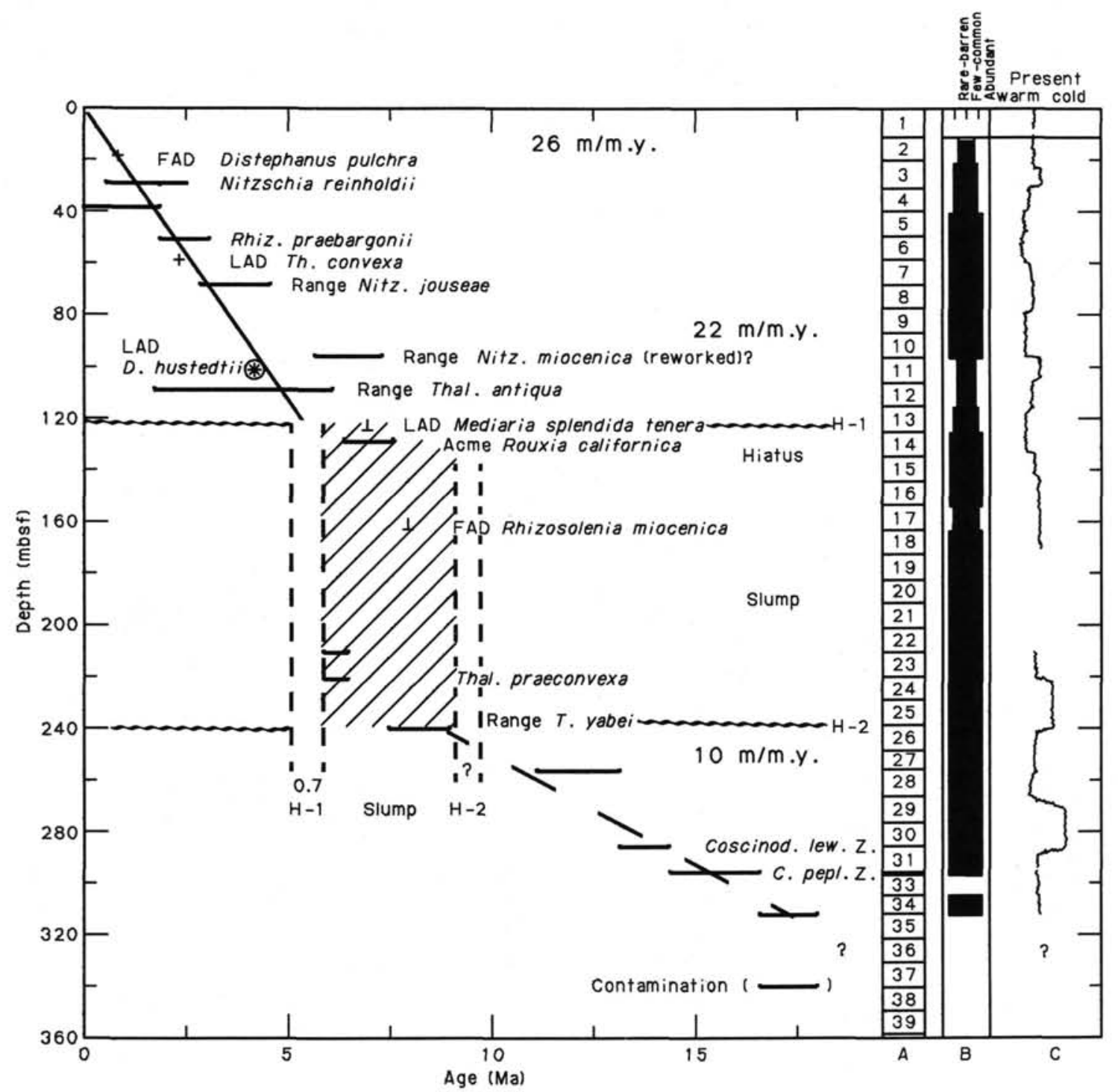

Figure 18. Sedimentation rates based on diatom LAD and FAD. Abundance of diatoms in Rare, Few, Common, Abundant are indicated in Column B. Column C indicates generalized climatic curve during warm-cold changes. Two hiatuses ( $\mathrm{H}-1$ and $\mathrm{H}-2)$ separate a late Miocene slump deposit from the rest of the section. 
was a useful datum already in early stratigraphical studies of silicoflagellates (Martini, 1971: frequency change " $D$. fibula/D. rhombica") and which occurs in the lower part of the late Miocene calcareous-nannoplankton Zone NN11 (Martini, 1976) was noted in Core 112-682A-13X. The base of the Dictyocha varia Zone is placed in Core 112-682A-28X, where the last occurrence of Corbisema triacantha was found. In Core 112-682A-31X the Distephanus stauracanthus stauracanthus Zone was identified. The base of the Corbisema triacantha Zone occurs between Cores 112-682A-34X and 112-682A-35X because we encountered rare Naviculopsis biapiculata in Sample 112-682A-35X-1, 21-22 cm. It has its last occurrence in the early Miocene.

The silicoflagellates are associated with common to abundant diatoms, rare to few sponge spicules and, occasionally, with actiniscidians and ebridians. These include Actiniscus pentasterias, A.(?) elongatus as well as Parathranium clathratum and Ammodochium serotinum found in low numbers throughout the early Miocene to Quaternary of Hole 682A. Below Core $112-682 \mathrm{~A}-37 \mathrm{X}$, samples contain none of these siliceous microfossils.

\section{Calcareous Nannoplankton}

In Hole 682A Quaternary calcareous nannoplankton wasfound in monotonous assemblages from Cores 112-682A-1H to 112-682A-3H. Species identified include Emiliania huxleyi in Sample 112-682A-1H-2, 95-96 cm, which indicates the presence of nannoplankton Zone NN21 (Emiliania huxleyi Zone) in the upper part of Core 112-682A-1H. The nannoplankton assemblages of the remaining part of this interval are dominated by Gephyrocapsa oceanica and Gephyrocapsa aperta as well as Cyclococcolithus leptoporus (Sample 112-682A-2H-6, 62-63 cm), whereas Helicosphaera carteri and Coccolithus pelagicus are rare. Because Pseudoemiliania lacunosa is extremely rare or missing in this area, the above interval is a combined Zone NN19b/ Zone NN20 (upper part of Pseudoemiliania lacunosa Zone and Gephyrocapsa oceanica Zone), based on cross-correlation with silicoflagellates.

Cores $112-682 \mathrm{~A}-4 \mathrm{H}, 112-682 \mathrm{~A}-5 \mathrm{X}$ and $112-682 \mathrm{~A}-6 \mathrm{H}, 112-$ $682 \mathrm{~A}-9 \mathrm{X}$ to $112-682 \mathrm{~A}-14 \mathrm{X}$, and $112-682 \mathrm{~A}-16 \mathrm{X}$ have no calcareous nannoplankton.

In Section 112-682A-7X, CC we noted several Discoaster brouweri in an otherwise undiagnostic nannoplankton assemblage, and because of the unknown occurrence of index species in the late Pliocene of this region, the sample is placed into the combined interval between Zones NN16 (Discoaster surculus Zone) to NN18 (Discoster brouweri Zone), above the last occurrence of Reticulofenestra pseudoumbilica. This species together with Sphenolithus abies and others are present in Sample 112$682 \mathrm{~A}-8 \mathrm{X}-1,44-45 \mathrm{~cm}$, which we placed in the early Pliocene nannoplankton Zone NN15 (Reticulofenestra pseudoumbilica Zone).

The nannoplankton assemblages of Cores 112-682A-15X, $112-682 \mathrm{~A}-17 \mathrm{X}$ to $112-682 \mathrm{~A}-20 \mathrm{X}$, and $112-682 \mathrm{~A}-22 \mathrm{X}$ to 112 682A-26X were not assigned ages. These include Discoaster variabilis in most samples with Discoaster brouweri and Discoaster exilis present at some levels. These samples seem to represent the upper part of the middle Miocene, but cannot be assigned definitely to certain nannoplankton zones because of low diversity and lack of index species. In many samples we noted dolomite rhombs in varying abundance. We believe that the growth of authigenic dolomite diminishes the calcareous-nannoplankton tests during diagenesis if the total carbonate content in the sediments is low. This "scavenging" of carbonate could lead to an impoverished assemblage having poor preservation or even result in a total loss of calcareous nannoplankton. The occurrence of Discoaster kugleri in Core 112-682A-27X places it into the middle Miocene nannoplankton Zone NN7 (Discoaster kugleri
Zone). The underlying Cores 112-682A-28X and 112-682A-29X represent nannoplankton Zone NN6 (Discoaster exilis Zone), since we did not find Sphenolithus heteromorphus, but did find Cyclococcolithus floridanus in samples from these cores. In Cores 112-682A-30X and 112-682A-31X we recovered only gravel. No calcareous-nannoplankton data were available. Sphenolithus heteromorphus was present in Core 112-682A-32X (bottom), and the interval between this sample and just above Section 112-682A-34X, CC, containing Helicosphaera ampliaperta, was placed in nannoplankton Zone NN5 (Sphenolithus heteromorphus Zone).

The lower Miocene sequence seemed complete, and calcareous-nannoplankton Zones NN4 (Helicosphaera ampliaperta Zone) to NN1 (Triquetrorhabdulus carinatus Zone) were identified in Cores 112-682A-34X to 112-682A-36X despite the absence of Sphenolithus belemnos. Triquetrorhabdulus carinatus is present in well-preserved specimens, and we also noted rare Discoaster druggii. Because the abundance of siliceous components declines greatly during the early Miocene at this site, sedimentation rates are low and the lower Miocene sequence seems to be somewhat less thick when compared with those of the middle and upper Miocene.

The Oligocene is represented by Cores $112-682 \mathrm{~A}-37 \mathrm{X}$ to 112 $682 \mathrm{~A}-44 \mathrm{X}$ but is difficult to subdivide because sphenoliths are not preserved or are missing in the poorly preserved nannoplankton assemblages in the middle and late Oligocene. On the basis of the presence of Coccolithus abisectus, which has its first occurrence near the base of nannoplankton Zone NP24 (Sphenolithus distentus Zone), and Dictyococcites dictyodus, which ranges across the Oligocene/Miocene boundary, Cores $112-682 \mathrm{~A}-38 \mathrm{X}$ and $112-682 \mathrm{~A}-39 \mathrm{X}$ were placed in the combined Zone NP24/25 (Sphenolithus distentus/S. ciperoensis Zone). Cores 112-682A-40X, 112-682A-42X, and 112-682A-43X are barren of calcareous nannoplankton, but we noted a rather meager nannoplankton assemblage in Core 112-682A-41X. It contains rare Coccolithus abisectus and Triquetrornabolulus cf. carinatus. We tentatively assigned this assemblage to the late Oligocene nannoplankton Zones NP24/25. The assemblage may represent downhole contamination. In Core $112-682 \mathrm{~A}-44$, a moderately preserved nannoplankton assemblage with frequent Reticulofenestra umbilica, Isthmolithus recurvus, and Cyclococcolithus formosus was found, indicating the presence of the early Oligocene nannoplankton Zone NP21 (Ericsonia subdisticha Zone) at this level.

The remaining sequence from Core $112-682 \mathrm{~A}-45 \mathrm{X}$ down to the terminal Core $112-682 \mathrm{~A}-48 \mathrm{X}$ at $436.7 \mathrm{mbsf}$ are of middle Eocene age. Discoaster saipanensis, which has its first occurrence near the top of Zone NP16 (Chiasmolithus solitus Zone), is found throughout Cores $112-682 \mathrm{~A}-45 \mathrm{X}$ to $-48 \mathrm{X}$ together with rare Chiasmolithus solitus indicating the upper part of Zone NP16. A sequence from the uppermost Eocene was not recovered, and we believe there is a hiatus between the early Oligocene and middle Eocene.

The occurrence of the "nearshore" and "shallow-water" genera Braarudosphaera and Discolithina in the lower Oligocene Core $112-682 \mathrm{~A}-44 \mathrm{X}$ and in the middle Eocene Cores 112-682A$45 \mathrm{X}$ through 112-682A-48X (also associated with representatives of the genus Micrantholithus in this core) indicates a shallower paleodepth for Site 682 during the early Oligocene and late middle Eocene than that from the late Oligocene to Holocene (Cores $112-682 \mathrm{~A}-1 \mathrm{H}$ to $112-682 \mathrm{~A}-41 \mathrm{X}$ to $112-682 \mathrm{~A}-1 \mathrm{H}$ ).

We observed reworked calcareous nannoplankton at two intervals. The most obvious reworking took place in the early Oligocene because Upper Cretaceous species occur frequently in samples from Core 112-682A-44X. These species include Watznaueria barnesae, Cretarhabdus crenulatus, and Tetralithus trifidus, with the latter occurring only in the upper Campanian and lower Maestrichtian. The other interval includes at least 
Cores 112-682A-15X through 112-682A-23X, where lower Miocene species such as Helicosphaera ampliaperta and Discoaster deflandrei occurred sporadically in late middle Miocene to early upper Miocene nannoplankton assemblages.

\section{Radiolarians}

\section{Hole $682 A$}

All core-catcher samples from this hole were studied for radiolarians. These are often absent or have poor preservation except in a few samples. When present, their preservation is generally good in Quaternary to Miocene samples but poor from the lower Miocene to the base of the hole ( $436.7 \mathrm{mbsf})$.

Cycladophora davisiana, Euchitonia sp., Dictyocoryne profunda, Pterocanium trilobum, Spongocore puella, Botryostrobus auritus australis, Saturnalus circularis, Lophospyris pentagona, Pterocorys zancleus, Tetrapyle octacantha, Stichopylium bicorne, Eucyrtidium acuminatum, and Giraffospyris angulata were found in Sections 112-682A-1H, CC through 112-682A$5 \mathrm{X}, \mathrm{CC}$. These indicate a Pliocene to Quaternary age. The presence of Didymocyrtis tetrathalamus in Section 112-682A-1H, $\mathrm{CC}$ restricts the age of this sample to upper Pliocene to Quaternary. The presence of Lamprocyrtis nigrinae in Section 112$682 \mathrm{~A}-3 \mathrm{H}, \mathrm{CC}$ places this sample in the Quaternary.

Saturnalus circularis, Euchitonia sp., Cycladophora davisiana, Pterocanium, hirundo, Botryostrobus auritus australis, Anthocyrtidium ophirense, and Theocorythium vetulum were found in Section 112-682A-6H, CC. Theocorythium vetulum has its last appearance datum (LAD) in the Anthocyrtidium angulare Zone. Thus, this assemblage is of Pliocene age or older.

Cyrtopera languncula, Cycladophora davisiana, Spongocore puella, Botryostrobus aquilonaris, B. auritus australis, Pterocanium praetextum, Euchitonia furcata, Siphocampe lineata, and Theocalyptra bicornis were found in Section 112-682A-7X, CC. This assemblage is indicative of Pliocene or Quaternary age.

Tholospyris scaphipes, Spongocore puella, Anthocyrtium zanguebaricum, Stylodictya validispina, Botryostrobus auritus australis, Cycladophora davisiana, Pterocanium trilobum, Lamprocyrtis neoheteroporos, Lyriospyris toxarium, and Lychnocanium audax were found in Section 112-682A-8X, CC. These identify the Spongaster pentas Zone, which is of early Pliocene age.

Saturnalus circularis, Stichocorys sp., Pterocanium prismatium, Stylotractus universus, Dendrospyris sp., Xiphosphaera circularis, Dictyophimus cf. craticula, Cycladophora davisiana, Botryostrobus aquilonaris and B. austris australis were found in Section 112-682A-9X, CC. This assemblage indicates a Pliocene age. One specimen of Lamprocyrtis nigriniae was also found. This species first occurs near the base of the Anthocyrtidium angulare Zone, which belongs to the Quaternary. If the presence of this species is confirmed later, we will have to consider this species a contamination (downhole?, during preparation?) or to extend its stratigraphic range downward (diachronous range in Peruvian continental margin?).

Botryostrobus aquilonaris, B. austris australis, Tholospyris scaphipes, and Theocorythium vetulum were found in Section 112-682A-10X, CC. These indicate a Pliocene to early Quaternary age. Based on results from Section 112-682A-8X, CC, this assemblage is placed in the early Pliocene.

Tholospyris scaphipes and Spirocyrtis subscalaris were found in Section 112-682A-18X, CC. The first appearance datum (FAD) of $S$. subscalaris falls within the Calocycletta costata Zone (early Miocene). Thus, this sample is younger than the early Miocene.

Tholospyris scaphipes, Phorticium pylonium, Antarctissa deflandrei, Stichocorys delmontensis, ?Botryostrobus bramlettei,
Stylochlamidium asteriscus, and Didymocyrtis mammifera were found in Section 112-682A-20X, CC. This assemblage indicates a time span from the upper $C$. costata Zone to the lowest Diartus pettersoni Zone, which corresponds to the middle Miocene.

Stichocorys delmontensis, Antarctissa strelkovi, Hymeniastrum sp., Stylodictya validispina, and Carpocanopsis favosa were found in Section 112-682A-21X, CC. This assemblage ranges from the Calocycletta costata Zone to the Didymocyrtis penultima Zone, which represents a time span from middle to late Miocene.

Siphostichoartus corona, Didymocyrtis mammifera, D. laticonus, Phorticium polycladum, Cyrtocapsella tetrapera, C. japonica, Cornutella profunda, Phormocyrtis stabilis, and Calocycletta caepa were found in Section 112-682A-23X, CC. This assemblage indicates the base of the $D$. pettersoni Zone, which is late middle Miocene in age.

Didymocyrtis laticonus was found in Section 112-682A-27X, CC. It ranges from the base of the $D$. pettersoni Zone to the uppermost $D$. alata Zone, which is still of late middle Miocene age.

Stylochlamidium asteriscus, Cycladophora davisiana cornutoides, Phorticium pylonium, P. polyedra, Cyrtocapsa tetrapera, Lithelius sp., Phormostichoartus fistula, and Stylodictya validispina were found in Section 112-682A-29X, CC. This assemblage ranges from the $C$. tetrapera Zone to the base of the $D$. pettersoni Zone, which represents an early to middle Miocene age.

Cycladophora davisiana cornutoides, Hexacontium sp., Stichocorys wolffi, Didymocyrtis mammifera, and D. violina were found in Section 112-682A-32X, CC. This assemblage ranges from the $C$. costata Zone to the base of the Dorcadospyris alata Zone, which indicates a period from a late early to early middle Miocene age.

Stichocorys wolffi, Calocycletta costata, Stichocorys delmontensis, Cyrtocapsella tetrapera, Didymocyrtis mammifera, D. violina, Calocycletta serrata, Tholospyris kantiana, T. anthopora, T. scaphipes and Liriospyris mutuaria were found in Section 112-682A-34X, CC. This assemblage indicates a range from the Calocycletta costata Zone to the base of the D. alata Zone, which indicates a late lower Miocene to early middle Miocene age.

Stichocorys delmontensis, Didymocyrtis violina, Cyrtocapsella tetrapera, Calocycletta virginis, Eucyrtidium cienkowskii, Phormostichoartus marylandicus, Phorticium polynium, Tholospyris scaphipes, Cycladophora davisiana, Cornutella sp., and Dendrospyris pododendros were found in Section 112-682A-35X, CC. This assemblage ranges from the middle part of the $C$. tetrapera Zone to the lower part of the $D$. alata Zone, which is of early lower Miocene to early middle Miocene age.

The following species were identified despite poor preservation in Section 112-682A-46X, CC: Eusyringium fistulegerum, Dictyoprora mongolfieri, "D. sp. aff. amphora" (Nigrini, 1977), D. mongolfieri, and Lychnocanoma cf. bellum, which occur in the middle Eocene (Riedel and Sanfilippo, 1978; Kling, 1978).

The state of preservation declines further in Section 112682A-47X, CC, and the only identifiable specimens were: Dictyoprora amphora, D. amphora? or mongolfieri?, "D. sp. aff. mongolfieri" (Nigrini, 1977), and Lamptonium fabaeforme fabaeforme. The time span of this assemblage is late early Eocene to middle Eocene.

Preservation in Section 112-682A-48X, CC is very poor: only Dictyoprora amphora, and Eusyringium fistuligerum were identified. One form is tentatively identified as Eusyringium lagena. The age of this assemblage is middle middle Eocene to middle late Eocene. If the presence of E. lagena is confirmed, the time span is restricted to the middle middle Eocene. 
All the other samples were barren (Sections 112-682A-11X, $\mathrm{CC}$ to $112-682 \mathrm{~A}-17 \mathrm{X}, \mathrm{CC}, 112-682 \mathrm{~A}-22 \mathrm{X}, \mathrm{CC}, 112-682 \mathrm{~A}-24 \mathrm{X}$, $\mathrm{CC}$ to $112-682 \mathrm{~A}-26 \mathrm{X}, \mathrm{CC}, 112-682 \mathrm{~A}-28 \mathrm{X}, \mathrm{CC}, 112-682 \mathrm{~A}-30 \mathrm{X}$, $\mathrm{CC}$ and $112-682 \mathrm{~A}-31 \mathrm{X}, \mathrm{CC}, 112-682 \mathrm{~A}-36 \mathrm{X}, \mathrm{CC}$ to $112-682 \mathrm{~A}-$ $45 \mathrm{X}, \mathrm{CC})$.

\section{Planktonic Foraminifers}

\section{Hole $682 A$}

All core-catcher samples were examined for planktonic foraminifers. A few well-preserved species occurred in Sections 112682A-1H, CC and 112-682A-2H, CC. Age-diagnostic forms are present in Sections 112-682A-35X, CC, 112-682A-38X, CC, 112 $682 \mathrm{~A}-44 \mathrm{X}, \mathrm{CC}, 112-682 \mathrm{~A}-46 \mathrm{X}, \mathrm{CC}$, and 112-682a-48X, CC. The other samples were barren or contained very rare specimens. The uppermost cores can be placed in the Pleistocene, and those lower in the hole are placed in the early Miocene, Oligocene, and middle Eocene.

Globigerina bulloides, G. falconensis, G. quinqueloba, Globigerinoides ruber, Globorotaloides hexagona, Neogloboquadrina humerosa, and N. pachyderma were found in Section 112$682 \mathrm{~A}-1 \mathrm{H}, \mathrm{CC}$. The cool-water species predominated in this sample.

Globigerina bulloides, Globigerinita glutinata, Orbulina universa, Globorotalia obesa, G. menardii, G. scitula scitula, G. tumida tumida, Neogloboquadrina blowi, N. dutertrei, N. eggeri, $N$. humerosa, N. pachyderma, Pulleniatina obliquiloculata, and Sphaeroidinella dehiscens were found in Section 112$628 \mathrm{~A}-2 \mathrm{H}, \mathrm{CC}$. These species indicate a mixed assemblage of cool- and warm-water regions. Sphaeroidinella dehiscens is restricted to tropical regions (Bé,1977). The above assemblage indicates a Pleistocene (N22) age, based on the range of Neogloboquadrina dutertrei, $N$. humerosa, and dextral-coiling Pulleniatina obliquiloculata.

The following planktonic foraminifers (which are not age-diagnostic) occur in Sections 112-682H-3H, CC, 112-682A-6H, $\mathrm{CC}, 112-682 \mathrm{~A}-17 \mathrm{X}, \mathrm{CC}, 112-682 \mathrm{~A}-18 \mathrm{X}, \mathrm{CC}$, and 112-682A19X, CC: Globigerina falconensis, Globigerinita glutinata, $G$. uvula, Globorotalia hexagona, Globorotalia minutissima, and G. obesa.

Globigerina falconensis, G. praebulloides, G. woodi, Globorotaloides hexagona, Globorotalia acrostoma, G. birnageae, $G$. obesa, G. siakensis, and Catapsydrax stainforthi were found in Section 112-682H-35X, CC. The range of Catapsydrax stainforthi is from Zone N4 to the basal part of Zone N7 (Blow, 1969; Berggren, 1977a). The FAD of Globorotalia birnageae is Zone N6 (Poore, 1979). Based on planktonic foraminifers, this sample is placed in Zone N6/N7, of early Miocene age.

Globigerina euapertura, Globoquadrina dehiscens, G. praedehiscens, Globorotalia acrostoma, G. birnageae, G. siakensis, G. suteri, Catapsydrax stainforthi, C. unicava, and Cassigerinella chipolensis were found in Section 112-682A-38X, CC. The range of Globorotalia birnageae is from Zone N7 to N8. On the basis of the above planktonic foraminifers, this sample is placed in Zone N7, of early Miocene age.

Rare specimens of Chiloguembelina cubensis and Pseudohastigerina barbadoensis were recognized in Section 112-682A$44 \mathrm{X}, \mathrm{CC}$. Chiloguembelina cubensis ranges from Zone P13 to Zone P22 (Berggren, 1977a), while the range of Pseudohastigerina barbadoensis is from Zone P16 to Zone P19 (Blow, 1969; Berggren, 1977b). For this reason, we placed this sample in the interval of Zones P16 to P19, of late Eocene to Oligocene age.

Acarinina topilensis, A pseudotopilensis, A. spinuloinflata, Globigerina inaequispira, G. linaperta and Catapsydrox unicava were found in Section 112-682A-46X, CC. Both Acarinina topilensis and Acarinina spinuloinflata range from Zones P9 to P14 (Berggren, 1977b). The range of C. unicava is from Zones P14 to N6. Based on planktonic foraminifers, this sample was placed in Zone P14, of middle Eocene age. Rare species of Acarinina broedermanni and $A$. pentacamerata were recognized in Section $112-682 \mathrm{~A}-48 \mathrm{X}, \mathrm{CC}$. This sample is of the same early Eocene age as Section 112-682A-46X, CC.

\section{Benthic Foraminifers}

\section{Hole $682 A$}

Benthic foraminifers fluctuated between none and many in various parts of the drilled sequence. Seven assemblages were sampled; transported tests occurred in most samples and dominated samples in certain intervals.

The characteristics and occurrences of the assemblages are as follows:

\section{Uvigerina senticosa Assemblage}

Benthic foraminifers are common and well preserved in this assemblage in Section 112-682A-1H, CC (9.7 mbsf). A number of species were few to rare with poor preservation in Sections 112-682A-5X, CC and 112-682A-6X, CC (39.8 and $55.5 \mathrm{mbsf}$ ). In addition to the nominal species, Oridorsalis umbonatus is abundant and Cassidulina depressa, Gyroidina turgida, and Pullenia bulloides are common. This assemblage occurs at lower bathyal depths in the modern ocean.

\section{Epistominella exigua Assemblage}

Foraminifers are common and well preserved in this assemblage, which occurs in Section 112-682A-2H, CC (18.8 mbsf). In addition to the nominal species, Astrononion schwageri, Cassidulina depressa, and Uvigerina auberiana are common or abundant. This assemblage occurs in lower bathyal depths in the modern ocean.

\section{Bolivina granti Assemblage}

Foraminifers are abundant and well preserved in this assemblage from Section 112-682A-15X, CC (134.7 mbsf). In addition to the nominal species, Epistominella subperuviana is abundant, and Bolivina seminuda var. (small), and Cassidella are common. An upper middle bathyal environment is indicated for the assemblage, which resembles assemblages described from the late Miocene (Mohnian) of California (Kleinpell, 1938).

\section{Epistominella thalmanni Assemblage}

Foraminifers are abundant and well preserved in this assemblage, which occurs in Sections 112-682A-16X, CC through 112682A-9X, CC (143.1-171.9 mbsf). Associated with the nominal species are Buliminella subfusiformis, Gyroidina multilocula, Bolivina seminuda var. (small), and Epistominella smithi. Bolivina ecuadorana occurs in Sections 112-682A-18X, CC and 112682A-19X, CC; Valvulineria cf. depressa occurs in Section 112 $682 \mathrm{~A}-19 \mathrm{X}, \mathrm{CC}$. These species occur in outer-shelf to middlebathyal environments.

\section{Uvigerina rustica-U. gallowayi Assemblage}

Foraminifers are common and moderately well preserved in this assemblage occurring in Sections 112-682A-33X, CC and 112-682A-34X, CC (295.3-209.5 mbsf) and rare, with poor preservation in Section 112-682A-35X, CC (315.2 mbsf). Uvigerina mantaensis is most abundant in the assemblage, and Gyroidina altiformis also occurs. This assemblage of the upper-middle bathyal environment resembles that of middle Miocene strata off the Agua Salada Group of Venezuela (Renz, 1948).

\section{Melonis pompilioides-Bulimina alazanensis Assemblage}

Foraminifers of this assemblage are abundant and moderately well preserved in Section 112-682A-38X, CC (344.4 mbsf) 
and rare, with poor preservation in Section 112-682A-37X, CC (333.5 mbsf). Bathysiphon sp., Bolivina multicostata, Gyroidina altiformis, and Oridorsalis umbonatus are common. These species signify a lower-bathyal habitat. Twenty-three (almost all) of the species found in the sample occur in Oligocene-Miocene ("Aquitanian") strata of the Goajira Peninsula, Colombia (Becker and Dusenbury, 1958).

\section{Bulimina chirana Assemblage}

Foraminifers of this assemblage are common and moderately well preserved in Section 112-682A-46X, CC (409.9 mbsf) and few and moderately well preserved in Section 112-682A-48X, CC (427.6 mbsf). Twelve of the 17 species found also occur in the Chira Formation of late Eocene age in northwestern Peru (Cushman and Stone, 1947). This biofacies also has been recovered from the Peru margin (Kulm et al., 1986), where it was middle Eocene in age. Although most of the species of this assemblage, including the abundant forms, are extinct, the prevalence of buliminids of the Bulimina microcostata morphology and the presence of Bolivina basisenta indicate an upper bathyal to upper-middle bathyal environment (Ingle, 1980) for this assemblage, which occurs at the base of the cored sequence.

Evidence of transportation of specimens (mainly Buliminella elegantissima) from shelf depths to the various bathyal environments was found, particularly in the interval between Sections 112-682A-19X, CC and 112-682A-29X, CC (171.9 and 266.9 mbsf). Nothing was recovered below this interval (in Cores 112682A-30X through 112-682A-33X).

Evidence of reworked fossil material was found in Section 112-682A-44X, CC (397.1 mbsf). It contained silicified specimens from the Bulimina chirana biofacies below, as well as the shelf forms Buliminella elegantissima and Nonionella sp., in which the original shell material was preserved. These latter forms could have been transported from shallow water, or alternatively, they may have accompanied shallow, transgressive deposition after a hiatus. Section 112-682A-8X, CC (67.3 mbsf) contains the late Miocene-early Pliocene species Bolivina girardensis and $B$. californica, along with other species having a more modern lower-bathyal aspect. In this case, reworking is also suspected.

Samples from Sections 112-682A-3H, CC, 112-682A-4H, CC, and $112-682 \mathrm{~A}-10 \mathrm{X}, \mathrm{CC}$ through $112-682 \mathrm{~A}-13 \mathrm{X}, \mathrm{CC}$, as well as $112-682 \mathrm{~A}-47 \mathrm{X}, \mathrm{CC}$ were barren of foraminifers.

\section{Correlation of Eocene Strata Based on Foraminifers}

This section covers the micropaleontological analysis of samples from Sections 112-682A-46X, CC, 112-682A-47X, CC, and $112-682 \mathrm{~A}-48 \mathrm{X}, \mathrm{CC}$. The foraminifer species of the planktonic and benthic groups identified in these samples, we believe, represent index assemblages of the uppermost Eocene sediments, as defined in the Talara, Progreso, and Sechura basins of northwestern Peru. They have also been used to establish the correlation of the sedimentary strata of similar age encountered in drilled wells in the Pisco and Salaverry basins.

Following are the main foraminiferal species identified:

1. Benthic forms include Uvigerina chirana, U. mantaensis, Anomalina chirana, Vulvulina chirana, Epistomina eocenica, Bulimina cf. ovata, Cyclammina simiensis, Plectofrondicularia sp., Haplophragmoides sp. (Zone P10), Cibicides cf. martinezensis, $C$. perlucidus, and Bathysiphon eocenicus.

2. Planktonic forms include Clavigerinella eocenica, Catapsydrax dissimilis, $C$. stainforthi, and $C$. unicavus. We believe these forms are the most significant for age identification. With the above listed foraminifers, the sampled interval was placed in the earliest Eocene.
In the offshore well Delfin 20-X-1, the metamorphic basement was reached at $2602 \mathrm{~m}$ and was encountered below the Chira Formation. In the Pisco Basin as well as in the Bayovar areas, the basement was recognized below the upper Eocene Chira-Verdun sequence.

The age assigned to the Chira Formation onshore is based on the planktonic assemblage containing Hantkenina alabamensis, Chiloguembelina cubensis, Clavigerinella eocenica, and C. jarvisi (Cruzado, 1985).

In the Peruvian coastal basins, it is important to note the evolutionary trend of the genus Clavigerinella to define the middle/upper Eocene boundary. This genus appeared for the first time in the middle Eocene Chacra Formation under the clavaeshaped form named Clavigerinella colombiana and Clavigerinella akersi. The extinction of these two forms, giving way to the finger-shaped Clavigerinella eocenica was selected as the boundary between the middle and upper Eocene in this area (Stainforth et al., 1975).

\section{ORGANIC GEOCHEMISTRY}

Sediments sampled in Hole 682A were from the lower slope of the continental margin of Peru. These hemipelagic slope sediments were examined for hydrocarbon gases and organic carbon. Because this site was well within the zone of gas-hydrate stability, hydrocarbon gas concentrations and compositions were monitored closely. Methods and procedures are discussed more completely in the "Organic Geochemistry" section, Site 679 chapter (this volume). Instruments used are described in the "Explanatory Notes" (this volume).

\section{Hydrocarbon Gases}

Three different procedures were used to collect and measure gases at this site. Gases were extracted from sediments using the headspace and canned-gas procedure (see "Organic Geochemistry" section, Site 679 chapter for details). In addition, because gas pockets formed in the core liners starting with Core 112682A-12X (about $106 \mathrm{mbsf}$ ), vacutainer samples were collected from this depth to the bottom of the hole.

\section{Vacutainer Gases}

Vacutainers from the manufacturer were prepared by using the vacuum of the laboratory freeze dryer to remove contaminants and to establish a vacuum of about $25 \mathrm{in} . \mathrm{Hg}$, following the method of Kvenvolden and McDonald (1986). Gases within the core liners were recovered directly by means of a hollow punch equipped with a valve. After the punch penetrated the core liner, gas was vented through the valve into a $20-\mathrm{mL}$ vacutainer. The gases were analyzed by gas chromatography (HachCarle Gas Chromatograph), and the results are listed in Table 4. $\mathrm{C}_{1}$ concentrations range from $14.7 \%$ to $89.4 \%, \mathrm{C}_{2}$ concentrations generally are between 100 and $400 \mathrm{ppm}$, whereas $C_{3}$ concentrations usually are between 10 and $40 \mathrm{ppm}$.

The vacutainer gas sample from Core 112-682A-46X (409.2 mbsf) had anomalously high concentrations of $\mathrm{C}_{2}$ and $\mathrm{C}_{3}$. This unusual sample was recovered about $68 \mathrm{~cm}$ from the core catcher, the contents of which had a peculiar odor similar to that noticed at the bottom of Hole 679E. In addition to the $1100 \mathrm{ppm}$ of $\mathrm{C}_{2}$, this gas mixture also contained about $790 \mathrm{ppm}$ of ethene $\left(C_{2: 1}\right)$, a compound not detected in any other vacutainer sample collected at this site. We believe that the natural in-situ gas mixture obtained at this depth was contaminated with thermal-decomposition products resulting from overheating of organic substances associated with drilling. The sudden appearance of this anomalous gas mixture and, in particular, its unusual content of $\mathrm{C}_{2: 1}$, suggest that it represents a drilling artifact. In contrast, the gas in the following core, Core 112-682A- 
Table 4. Vacutainer gases at Hole $682 \mathrm{~A}$.

\begin{tabular}{|c|c|c|c|c|c|}
\hline $\begin{array}{l}\text { Core-section } \\
\text { interval }(\mathrm{cm})\end{array}$ & $\begin{array}{l}\text { Depth } \\
\text { (mbsf) }\end{array}$ & $\begin{array}{l}C_{1} \\
(\%)\end{array}$ & $\underset{(\mathrm{ppm})}{\mathrm{C}_{2}}$ & $\begin{array}{c}\mathrm{C}_{3} \\
(\mathrm{ppm})\end{array}$ & $C_{1} / C_{2}$ \\
\hline $112-682 A-12 X-2$ (17) & 106.5 & 61.4 & 140 & 26 & 4300 \\
\hline $12 X-3(4)$ & 107.8 & 50.5 & 120 & 22 & 4300 \\
\hline $13 \mathrm{X}-1(56)$ & 114.9 & 72.1 & 170 & 30 & 4200 \\
\hline $14 X-2(15)$ & 125.5 & 74.3 & 190 & 34 & 3400 \\
\hline $15 X-1(32)$ & 133.6 & 70.7 & 170 & 33 & 4100 \\
\hline $17 X-1(43)$ & 152.7 & 38.1 & 110 & 20 & 3500 \\
\hline $18 \mathrm{X}-1(58)$ & 162.4 & 78.3 & 250 & 40 & 3200 \\
\hline $20 \mathrm{X}-2(22)$ & 182.5 & 75.5 & 190 & 29 & 4000 \\
\hline $21 X-1(60)$ & 190.9 & 67.3 & 180 & 28 & 3700 \\
\hline $22 \mathrm{X}-2(25)$ & 201.6 & 89.4 & 260 & 36 & 3400 \\
\hline $23 \mathrm{X}-1(79)$ & 210.1 & 72.3 & 230 & 29 & 3200 \\
\hline $24 X-1(102)$ & 219.8 & 71.2 & 250 & 36 & 2800 \\
\hline $25 \mathrm{X}-1(32)$ & 228.6 & 70.9 & 260 & 38 & 2800 \\
\hline $26 \mathrm{X}-1(65)$ & 238.5 & 68.6 & 200 & 27 & 3500 \\
\hline $27 X-1(74)$ & 248.0 & 73.7 & 230 & 30 & 3200 \\
\hline $34 X-1(142)$ & 306.0 & 74.7 & 430 & 44 & 1800 \\
\hline $36 X-1(82)$ & 321.5 & 46.3 & 240 & 27 & 1900 \\
\hline $37 X-3(12)$ & 333.3 & 68.0 & 260 & 32 & 2600 \\
\hline $38 X-3$ (26) & 343.0 & 83.0 & 300 & 35 & 2800 \\
\hline $39 X-2$ (98) & 351.8 & 84.9 & 240 & 34 & 3600 \\
\hline $40 X-3(83)$ & 362.5 & 88.4 & 250 & 31 & 3500 \\
\hline $45 X-1(25)$ & 404.0 & 14.7 & 48 & 5 & 3100 \\
\hline $46 X-1(104)$ & 409.2 & 86.9 & 1100 & 520 & 770 \\
\hline $47 X-3(30)$ & 421.0 & 83.8 & 260 & 14 & 3200 \\
\hline
\end{tabular}

Note: Units of $\%$ and ppm are in volume of gas component per volume of gas mixture. All measurements were made on the HachCarle Gas Chromatograph.

47X (421.0 mbsf), was normal in composition, thus amplifying the observation that the previous core contained an anomalous gas mixture.

The $\mathrm{C}_{1} / \mathrm{C}_{2}$ ratios measured on vacutainer gases are listed in Table 4 and shown in Figure 19. There is a slow overall decrease

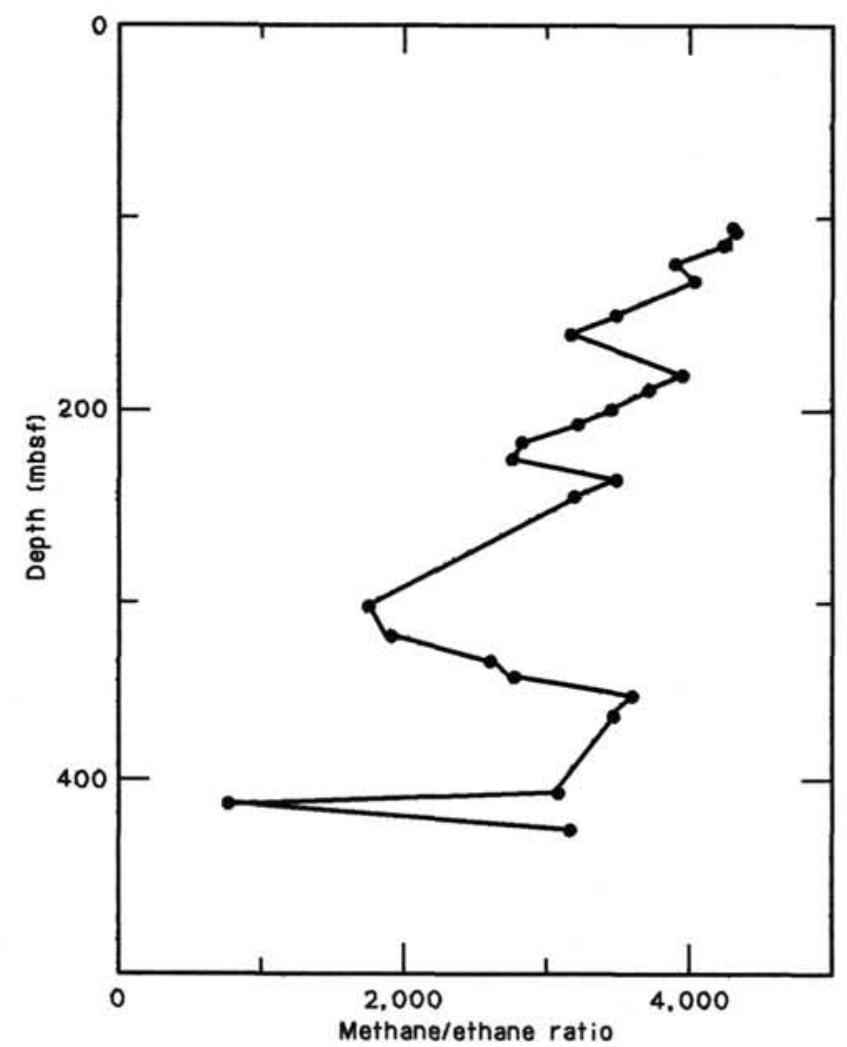

Figure 19. Methane/ethane ratios in gas collected by means of vacutainers from Hole $682 \mathrm{~A}$. in this ratio with depth due to early diagenetic formation of $\mathrm{C}_{2}$ from the low-temperature thermal decomposition of organic matter. Rice and Claypool (1981) suggested that the amount of $C_{2}$ appears to be proportional to both the temperature and the age of the sediment, and Claypool and Kvenvolden (1983) pointed out that an exponential increase in $\mathrm{C}_{2}$ with depth is commonly observed in oceanic sedimentary columns. At this site, although $C_{2}$ increases with depth, the increase is not exponential, which suggests that the thermal gradient here is very low or that the sediments are relatively young.

Figure 20 compares the $C_{1} / C_{2}$ ratios of the vacutainer gases with the drilling rates. There is a crude correlation between the overall trends in the $C_{2}$ contents and the drilling rates. Even though this correlation is probably coincidental, we observed an apparently causal relationship between the two parameters during three intervals of extremely slow rates of drilling (see Fig. 20). We concluded that below some "threshold" rate of drilling ( $\mathrm{m} / \mathrm{min})$, the drill bit begins to heat up and thermally alters sediment organic matter or drilling substance, producing excess $\mathrm{C}_{2}$ as one product. In the extreme case at about 410 mbsf, $C_{2: 1}$ was also produced as discussed above. This apparent relationship between hydrocarbon generation and extremely slow drilling rates will be tested at future sites.

\section{Extracted Gases}

Hydrocarbon gas concentrations resulting from the headspace and canned-gas procedures are shown in Tables 5 and 6 , respectively, and the abundances of $C_{1}$ extracted from the sediments by both procedures are presented in Figure 21. The headspace data provided a high-resolution record of gas concentra-

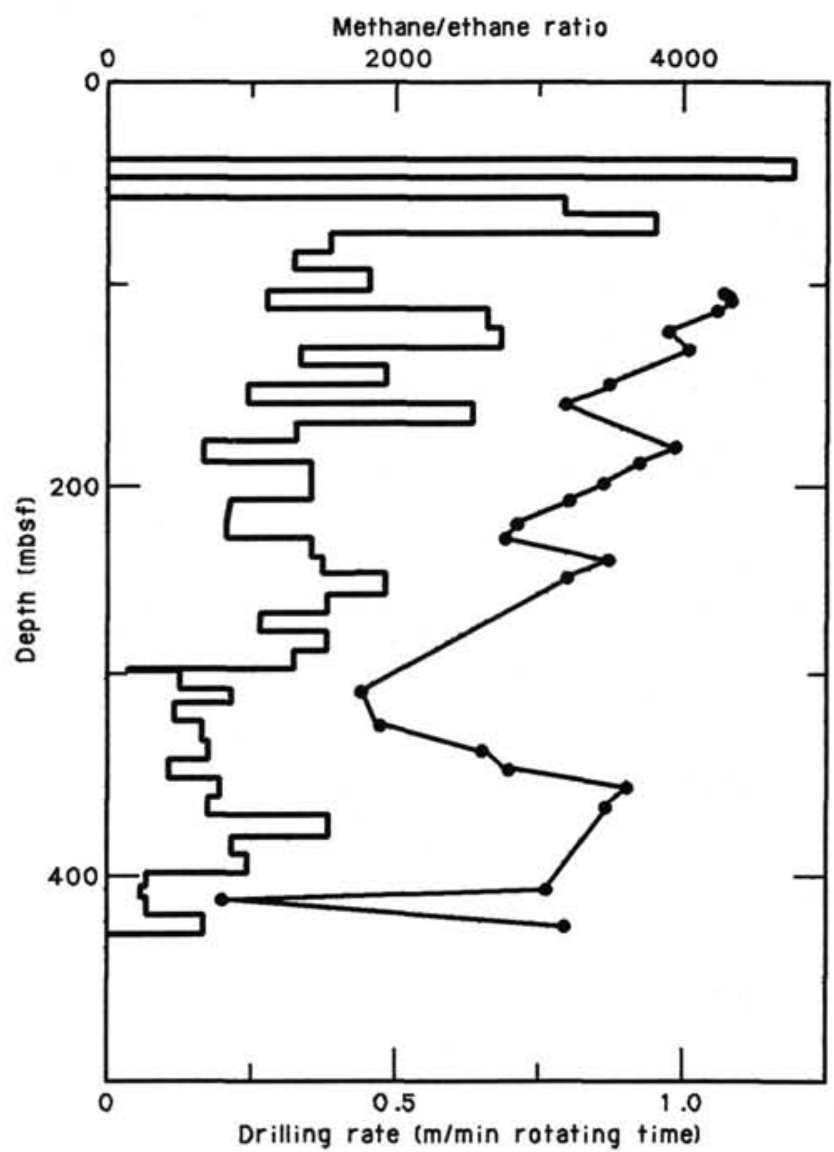

Figure 20. Comparison of methane/ethane ratios (Figure 19) and drilling rates $(\mathrm{m} / \mathrm{min}$ rotating time) at Hole $682 \mathrm{~A}$. Three intervals are shown where extremely slow rates of drilling appear to correlate with the generation of hydrocarbons such as $\mathrm{C}_{2}$. 
Table 5. Hydrocarbons determined by headspace procedure at Hole $682 \mathrm{~A}$.

\begin{tabular}{|c|c|c|c|c|c|}
\hline $\begin{array}{l}\text { Core-section } \\
\text { interval }(\mathrm{cm})\end{array}$ & $\begin{array}{l}\text { Depth } \\
\text { (mbsf) }\end{array}$ & $\begin{array}{c}\mathrm{C}_{1} \\
(\mu \mathrm{L} / \mathrm{L})\end{array}$ & $\begin{array}{c}\mathrm{C}_{2} \\
(\mu \mathrm{L} / \mathrm{L})\end{array}$ & $\begin{array}{c}\mathrm{C}_{3} \\
(\mu \mathrm{L} / \mathrm{L})\end{array}$ & $C_{1} / C_{2}$ \\
\hline $112-682 \mathrm{~A}-1 \mathrm{H}-3(139-140)$ & 4.4 & 73 & & & \\
\hline $3 \mathrm{H}-4(0-1)$ & 28.3 & 230 & 11 & & 21 \\
\hline $6 \mathrm{H}-4(0-1)$ & 52.3 & 57,000 & 32 & 8.5 & 1800 \\
\hline $7 X-1(149-150)$ & 58.8 & 120,000 & 32 & 2.3 & 3800 \\
\hline $9 X-1(100-101)$ & 77.3 & 21,000 & 24 & 13 & 880 \\
\hline $10 X-1(113-114)$ & 86.9 & 76,000 & 25 & 11 & 2400 \\
\hline $11 X-1(0-1)$ & 95.3 & 88,000 & 40 & 20 & 2200 \\
\hline $12 X-2(124-125)$ & 107.6 & 56,000 & 22 & 12 & 2000 \\
\hline $13 X-3(149-150)$ & 118.8 & 31,000 & 34 & 27 & 910 \\
\hline $14 X-2(0-1)$ & 126.8 & 100,000 & 48 & 28 & 2100 \\
\hline $15 X-1(128-129)$ & 134.6 & 40,000 & 47 & 40 & 850 \\
\hline $16 X-1(29-30)$ & 143.1 & 20,000 & 33 & 36 & 610 \\
\hline $17 X-1(149-150)$ & 153.8 & 33,000 & 66 & 51 & 500 \\
\hline $18 X-2(0-1)$ & 163.3 & 27,000 & 47 & 33 & 580 \\
\hline $20 X-2(0-1)$ & 182.3 & 85,000 & 100 & 89 & 860 \\
\hline $21 X-1(124-125)$ & 191.6 & 20,000 & 45 & 41 & 440 \\
\hline $22 \mathrm{X}-1(124-125)$ & 201.0 & 90,000 & 110 & 73 & 870 \\
\hline $23 X-1(111-112)$ & 210.4 & 20,000 & 53 & 50 & 370 \\
\hline $25 X-1(68-69)$ & 229.0 & 18,000 & 69 & 64 & 260 \\
\hline $26 \mathrm{X}-1(88-89)$ & 238.7 & 20,000 & 80 & 68 & 240 \\
\hline $27 X-1(118-119)$ & 248.5 & 7700 & 49 & 53 & 150 \\
\hline $28 \mathrm{X}-1(34-35)$ & 257.1 & 13,000 & 41 & 32 & 320 \\
\hline $34 X-3(0-1)$ & 307.6 & 20,000 & 95 & 59 & 210 \\
\hline $35 X-2(149-150)$ & 313.2 & 27,000 & 100 & 63 & 270 \\
\hline $36 \mathrm{X}-1(139-140)$ & 322.0 & 4000 & 65 & 60 & 60 \\
\hline $37 \mathrm{X}-\mathrm{CC}(10-11)$ & 339.7 & 56,000 & 120 & 81 & 480 \\
\hline $38 X-3(0-1)$ & 342.7 & 5400 & 59 & 49 & 92 \\
\hline $38 \mathrm{X}-\mathrm{CC}(0-1)$ & 349.3 & 22,000 & 86 & 82 & 250 \\
\hline $39 \mathrm{X}-2(97-98)$ & 351.8 & 11,000 & 100 & 87 & 100 \\
\hline $40 X-2(149-150)$ & 361.7 & 43,000 & 180 & 110 & 240 \\
\hline $42 X-C C(11-12)$ & 377.8 & 200,000 & 320 & 240 & 630 \\
\hline $44 X-C C(7-8)$ & 403.7 & 11,000 & 46 & 31 & 240 \\
\hline $45 X-1(59-60)$ & 404.3 & 31,000 & 68 & 27 & 450 \\
\hline $46 \mathrm{X}-\mathrm{CC}(0-1)$ & 417.7 & 230,000 & 110 & 31 & 2200 \\
\hline $47 X-2(149-150)$ & 420.7 & 6400 & 37 & 6 & 170 \\
\hline
\end{tabular}

Note: Units are in microliters $(\mu \mathrm{L})$ of gas component per liter $(\mathrm{L})$ of wet sediment. All measurements were made on the Hach-Carle Gas Chromatograph.

Table 6. Hydrocarbon values determined by canned-gas procedure at Hole 682A.

\begin{tabular}{crrrrr}
\hline $\begin{array}{c}\text { Core-section } \\
\text { interval (cm) }\end{array}$ & $\begin{array}{c}\text { Depth } \\
\text { (mbsf) }\end{array}$ & $\begin{array}{c}\mathrm{C}_{1} \\
(\mu \mathrm{L} / \mathrm{L})\end{array}$ & $\begin{array}{c}\mathrm{C}_{2} \\
(\mu \mathrm{L} / \mathrm{L})\end{array}$ & $\begin{array}{c}\mathrm{C}_{3} \\
(\mu \mathrm{L} / \mathrm{L})\end{array}$ & $\mathrm{C}_{1} / \mathrm{C}_{2}$ \\
\hline $112-682 \mathrm{~A}-1 \mathrm{H}-3$ (140-145) & 4.4 & 29 & 0.7 & & \\
3H-3 (135-140) & 23.7 & 180 & 4.7 & & \\
9X-1 (101-106) & 77.3 & 95,000 & 45 & 16 & 2100 \\
15X-1 (129-134) & 134.6 & 19,000 & 18 & 15 & 1000 \\
21X-1 (125-130) & 191.6 & 35,000 & 64 & 39 & 530 \\
23X-1 (112-117) & 210.4 & 21,000 & 53 & 38 & 440 \\
34X-2 (135-140) & 307.5 & 29,000 & 123 & 45 & 230 \\
38X-2 (145-150) & 342.7 & 24,000 & 48 & 25 & 500 \\
46X-1 (135-140) & 409.6 & 41,000 & 160 & 140 & 260 \\
\hline
\end{tabular}

Note: Units are in microliters $(\mu \mathrm{L})$ of gas component per liter $(\mathrm{L})$ of wet sediment. All measurements were made on the Hach-Carle Gas Chromatograph.

tions with depth, as did the vacutainer results, whereas the canned-gas data yielded a low-resolution record because of the limited number of samples. Nevertheless, the overall profiles of headspace and canned-gas concentrations with depth (Fig. 21) show similar trends. Below about $28 \mathrm{mbsf}$, the amount of $\mathrm{C}_{1}$ in the sediment increases rapidly so that by about $60 \mathrm{mbsf}, \mathrm{C}_{1}$ concentrations reach a maximum of about $100,000 \mu \mathrm{L} / \mathrm{L}$ of wet sediment. The concentrations of $\mathrm{C}_{1}$ then decrease slightly and generally remain between 10,000 and $100,000 \mu \mathrm{L} / \mathrm{L}$ to the bottom of the hole. The limit to the amount of residual $\mathrm{C}_{1}$ that can be recovered by the headspace and canned-gas procedures appears to be about $100,000 \mu \mathrm{L} / \mathrm{L}$, with some exceptions. This limit probably depends on the solubility of $\mathrm{C}_{1}$ in water and the

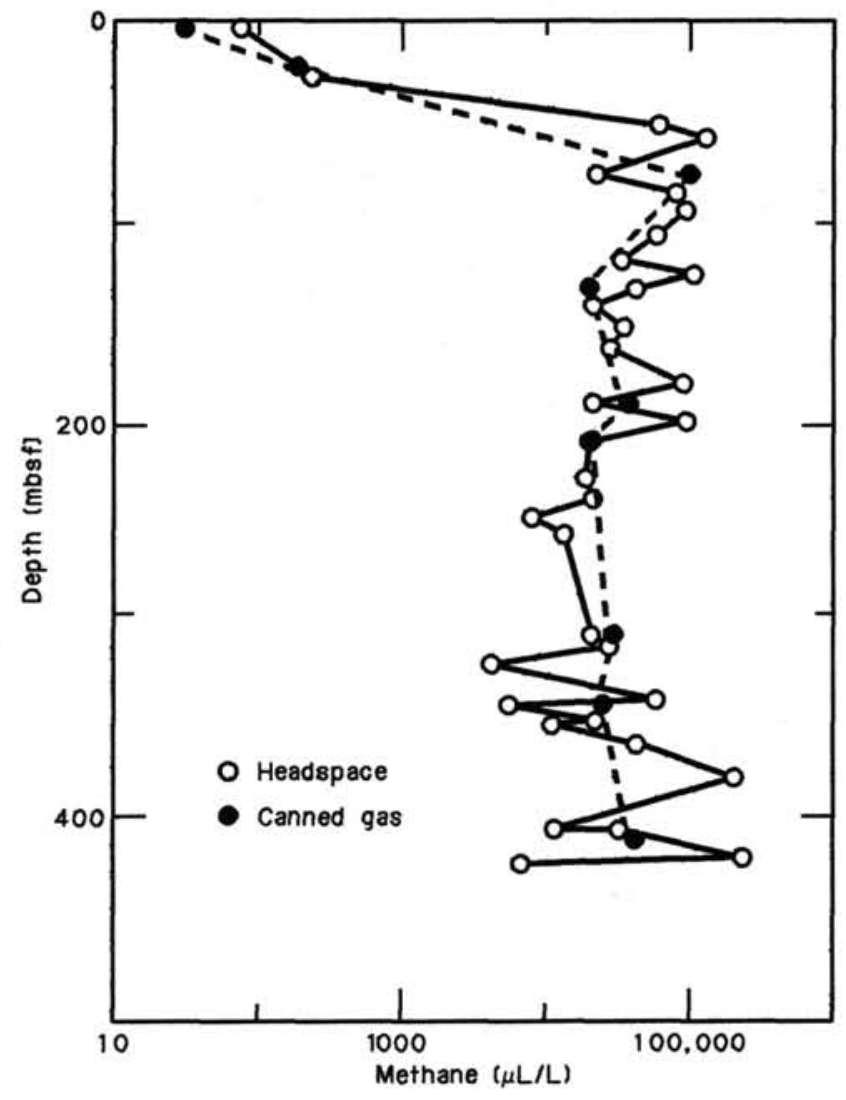

Figure 21. Comparison of methane concentrations with depth as obtained through headspace and canned-gas procedures at Site 682.

ability of the sediment to retain free $\mathrm{C}_{1}$. Headspace data from Cores 112-682A-42X and 112-682A-46X and canned-gas data from Core 112-682A-46X show anomalously high amounts of $\mathrm{C}_{1}, \mathrm{C}_{2}$, and $\mathrm{C}_{3}$. We believe that these gas mixtures have been affected by drilling.

The increase in $\mathrm{C}_{1}$ concentrations from the surface to about $60 \mathrm{mbsf}$ correlates well with the increase in organic carbon with depth (compare Figs. 21 and 22). This increase in $C_{1}$ correlates inversely with sulfate concentrations, which decrease from 28 $\mathrm{mmol} / \mathrm{L}$ at the surface to about $3 \mathrm{mmol} / \mathrm{L}$ at about $60 \mathrm{mbsf}$ and remain at this low level to the bottom of the hole (see "Inorganic Geochemistry" section, this chapter). These correlations affirm the biogenic nature of the $C_{1}$ at this site.

\section{Gas Hydrates}

Hole $682 \mathrm{~A}$ was drilled well within the pressure-temperature stability field for marine gas hydrates (Kvenvolden and McMenamin, 1980). The high concentrations of $C_{1}$ encountered at this site are comparable to those found in continental margin sediments where gas hydrates have been identified (Kvenvolden, 1985). For example, the minimum amount of $C_{1}$ observed where gas hydrates occur appears to be between 10,000 and 100,000 $\mu \mathrm{L} / \mathrm{L}$ wet sediment. The residual $\mathrm{C}_{1}$ concentrations in sediments from Hole $682 \mathrm{~A}$ are generally within this range. However, gas hydrates were not observed at this site. This failure to recover these substances was probably due to the poor core recovery that occurred here; the gas hydrates probably were destroyed during drilling.

Ancillary evidence for the presence of gas hydrates can be found in the pore-water chemistry (see "Inorganic Geochemistry" section, this chapter). Wherever gas hydrates have been observed in continental margin sediments, salinity and chloride 


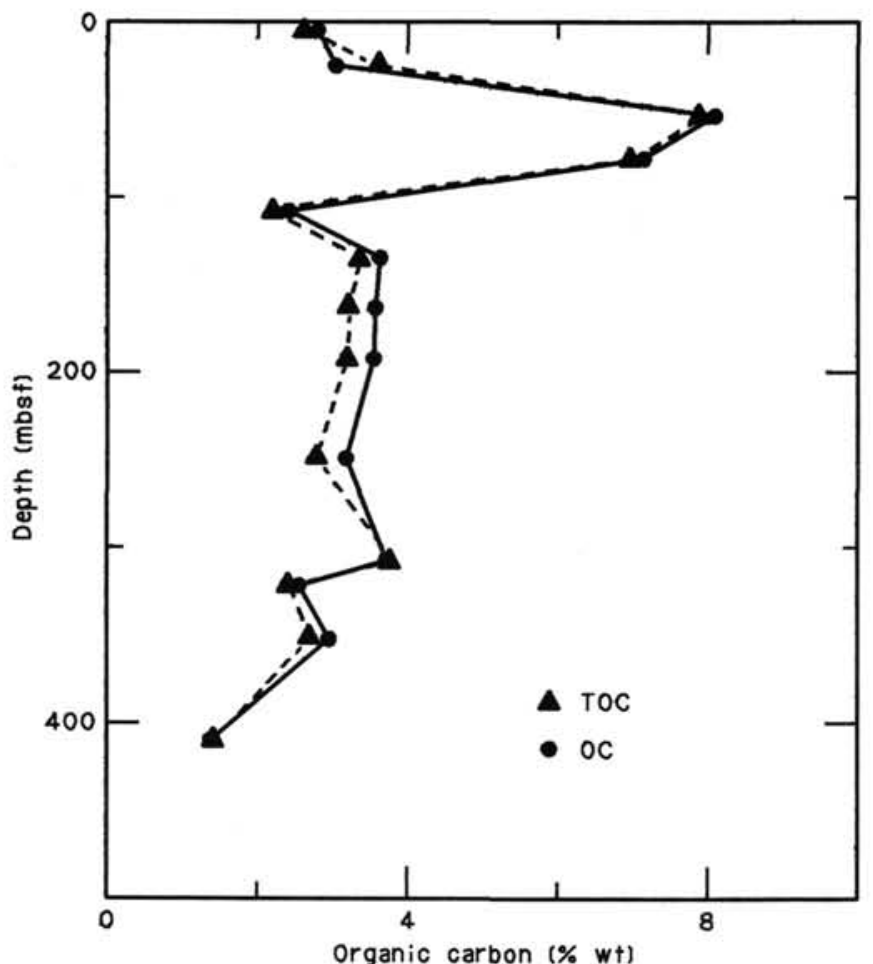

Figure 22. Comparison of organic carbon $(\mathrm{OC})$ by difference and total organic carbon (TOC) by pyrolysis with depth at Site 682 .

contents decrease with depth (Harrison et al., 1982: Kvenvolden and Barnard, 1983; Kvenvolden and McDonald, 1985). The sediments at Hole 682A are no exception; salinity decreases with depth from 34.0 to $30.2 \mathrm{~g} / \mathrm{kg}$ and chloride content from 559 to $512 \mathrm{mmol} / \mathrm{L}$ (see "Inorganic Geochemistry" section, this chapter).

On a seismic-reflection profile through this site, a well-developed bottom-simulating reflector (BSR) was observed at $0.58 \mathrm{~s}$ (two-way traveltime) about $8 \mathrm{~km}$ seaward of Site 682 . We believe that this BSR corresponds to the base of the zone where gas hydrates occur. If one assumes a seismic velocity of $1645 \mathrm{~m} / \mathrm{s}$, the BSR is located at a depth of 477 mbsf (see "Geophysics" section, this chapter). Using the temperature-pressure phase boundary for pure methane hydrate and the methods of Shipley et al. (1979), we calculated that the temperature at the BSR is about $25.5^{\circ} \mathrm{C}$. Thus, the geothermal gradient for the uppermost sediments at Site 682 is $49^{\circ} \mathrm{C} / \mathrm{km}$. This gradient appears to be high in relation to the observed slow increase in the concentrations of $\mathrm{C}_{2}$ with depth.

\section{Carbon}

Part of each of 13 sediment "squeeze-cakes" from the porewater chemistry studies was analyzed for total carbon, carbonate carbon, and organic carbon. The results are given in Table 7. These results indicate greater than $1.5 \%$ carbonate carbon only in the upper part of Hole 682A (Cores 112-682A-1H and 112$682 \mathrm{~A}-3 \mathrm{H}$ ). Organic-carbon values are high (greater than $2 \%$ ) for all samples except the deepest ones at $409.7 \mathrm{mbsf}$. The highest amounts occur in sediments between 52.3 and $77.5 \mathrm{mbsf}$ (Fig. 22). Apparently, oceanographic conditions were such that high concentrations of organic matter were deposited and preserved in this area during the Pliocene. Figure 22 also shows the total organic carbon (TOC), as measured by Rock-Eval pyrolysis. Agreement between the two methods is excellent.

Rock-Eval results are given in Table 8 . The organic matter in sediments at this site can be classified as immature and organic-
Table 7. Organic carbon and carbonate carbon for Hole $682 \mathrm{~A}$.

\begin{tabular}{crcccc}
\hline $\begin{array}{c}\text { Core-section } \\
\text { interval }(\mathrm{cm})\end{array}$ & $\begin{array}{c}\text { Depth } \\
\text { (mbsf) }\end{array}$ & $\begin{array}{c}\text { Total } \\
\text { carbon } \\
(\%)\end{array}$ & $\begin{array}{c}\text { Inorganic } \\
\text { carbon } \\
(\%)\end{array}$ & $\begin{array}{c}\text { Organic } \\
\text { carbon } \\
(\%)\end{array}$ & $\begin{array}{c}\text { TOC } \\
(\%)\end{array}$ \\
\hline $112-682 \mathrm{~A}-1 \mathrm{H}-3(145-150)$ & 4.5 & 4.67 & 1.86 & 2.81 & 2.69 \\
3H-3 (140-150) & 23.8 & 6.24 & 3.17 & 3.07 & 3.55 \\
6H-3 (140-150) & 52.3 & 8.98 & 0.88 & 8.10 & 7.96 \\
$9 \mathrm{X}-1(106-116)$ & 77.5 & 7.39 & 0.25 & 7.14 & 7.04 \\
$12 \mathrm{X}-1(140-150)$ & 106.3 & 2.65 & 0.20 & 2.45 & 2.28 \\
$15 \mathrm{X}-1(134-139)$ & 134.7 & 4.19 & 0.54 & 3.65 & 3.38 \\
$18 \mathrm{X}-1(145-150)$ & 163.3 & 4.34 & 0.75 & 3.59 & 3.24 \\
$21 \mathrm{X}-1(130-135)$ & 191.7 & 4.09 & 0.53 & 3.56 & 3.21 \\
$27 \mathrm{X}-1(106-111)$ & 248.4 & 3.81 & 0.62 & 3.19 & 2.80 \\
$34 \mathrm{X}-2(140-150)$ & 307.6 & 4.97 & 1.25 & 3.72 & 3.80 \\
$36 \mathrm{X}-1(140-150)$ & 322.2 & 3.02 & 0.44 & 2.58 & 2.45 \\
$39 \mathrm{X}-2(131-141)$ & 352.2 & 3.84 & 0.87 & 2.97 & 2.71 \\
$46 \mathrm{X}-1(140-150)$ & 409.7 & 2.36 & 0.97 & 1.39 & 1.44 \\
\end{tabular}

Note: TOC $=$ total organic carbon from Rock-Eval pyrolysis

rich. The Hydrogen Index (HI) and Oxygen Index (OI) values, when plotted on an HI/OI (Fig. 23), fall between the fields for type II and type III kerogen (Tissot and Welte, 1984), with the sediment containing the highest amounts of organic carbon plotting nearer the type II field. These results suggest that much of the carbon in the organic-rich sediments derived from mainly marine sources. The low OI values indicate that little oxidation has affected the organic matter.

\section{INORGANIC GEOCHEMISTRY}

\section{Introduction and Operations}

Only one hole was cored using the advanced piston APC) and extended-core barrel (XCB) corers at Site 682. A total of 15 (eight $10-\mathrm{cm}$ and five $5-\mathrm{cm}$ whole-round and two in-situ) interstitial-water samples were obtained for inorganic-geochemical analyses. These samples were analyzed for $\mathrm{pH}$, salinity, chlorinity, alkalinity, sulfate, phosphate, ammonia, silica, calcium, and magnesium. For whole-round samples, the routine interstitialwater sampling procedure was followed, i.e., samples were taken in Cores $112-682 \mathrm{~A}-1 \mathrm{H}, 112-682 \mathrm{~A}-3 \mathrm{H}$, and subsequently at every third core. Some 5-cm samples were taken from Core 112-682A$1 \mathrm{H}$ and also from four deeper cores (112-682A-15X, 112-682A$18 \mathrm{X}, 112-682 \mathrm{~A}-21 \mathrm{X}$, and 112-682A-27X) because poor sediment recovery precluded our taking $10-\mathrm{cm}$ samples.

The interstitial-water profiles at Site 682 show systematic variations downhole with distinct minima and maxima. The most pronounced of these downhole variations are decreases in salinity, $\mathrm{Cl}^{-}, \mathrm{SO}_{4}^{2-}, \mathrm{Mg}^{2+}$, and $\mathrm{Mg}^{2+} / \mathrm{Ca}^{2+}$ as opposed to increases in alkalinity, $\mathrm{NH}_{4}^{+}$, and $\mathrm{Ca}^{2+}$ (Figs. 24 to 28). Similar downhole variations, particularly of salinity and chloride, were observed during DSDP Leg 57 at Sites 438 and 439 near the Japan Trench (Moore and Gieskes, 1980), and during Legs 67 and 84 at Sites 497, 498 (also Site 496), and Sites 565, 568, and 570, respectively, from the slope of the Middle America Trench (Harrison et al., 1982; Hesse, et al., 1985). During Leg 57, the systematic downhole decreases in salinity and $\mathrm{Cl}^{-}$were interpreted to indicate fossil fresh water from a previously formed nearby subaerial area (Moore and Gieskes, 1980). At this time, gas hydrates had not yet been recovered by DSDP. Gas hydrates were subsequently recovered during DSDP Leg 67 at Sites 496 and 497. At Site 570 (DSDP Leg 84 ), a solid 1-m core of pure gas hydrate was recovered. After this find, the concentration gradients of salinity and $\mathrm{Cl}^{-}$at these latter sites were attributed to the decomposition of gas hydrates and the accompanied release of water. This produces a progressive dilution "artifact" in the interstitial waters from squeezed sediment samples; water in the gas hydrate lattice is pure $\mathrm{H}_{2} \mathrm{O}$. 
Table 8. Summary of Rock-Eval pyrolysis for Hole 682A.

\begin{tabular}{|c|c|c|c|c|c|c|c|c|c|c|}
\hline $\begin{array}{l}\text { Core/section } \\
\text { interval }(\mathrm{cm})\end{array}$ & $\begin{array}{l}\text { Depth } \\
\text { (mbsf) }\end{array}$ & $\begin{array}{l}\text { Temp. } \\
\left({ }^{\circ} \mathrm{C}\right)\end{array}$ & $S_{1}$ & $\mathrm{~S}_{2}$ & $\mathrm{~S}_{3}$ & PI & PC & $\begin{array}{l}\text { TOC } \\
(\%)\end{array}$ & $\mathrm{HI}$ & OI \\
\hline $112-682 \mathrm{~A}-1 \mathrm{H}-3$ (145-150) & 4.5 & 418 & 1.33 & 6.49 & 3.46 & 0.17 & 0.65 & 2.69 & 241 & 128 \\
\hline $3 \mathrm{H}-3$ (140-150) & 23.8 & 409 & 1.51 & 9.64 & 3.52 & 0.14 & 0.92 & 3.55 & 271 & 99 \\
\hline $6 \mathrm{H}-3(140-150)$ & 52.3 & 401 & 4.48 & 34.18 & 5.21 & 0.12 & 3.22 & 7.96 & 429 & 65 \\
\hline $9 X-1(106-116)$ & 77.5 & 402 & 3.60 & 29.95 & 4.01 & 0.11 & 2.79 & 7.04 & 425 & 56 \\
\hline $12 X-1(140-150)$ & 106.3 & 395 & 1.10 & 7.32 & 1.40 & 0.13 & 0.70 & 2.28 & 321 & 61 \\
\hline $15 X-1(134-139)$ & 134.7 & 413 & 1.63 & 13.93 & 2.40 & 0.10 & 1.29 & 3.38 & 412 & 71 \\
\hline $18 X-1(145-150)$ & 163.3 & 403 & 1.72 & 14.84 & 2.53 & 0.10 & 1.38 & 3.24 & 458 & 78 \\
\hline $21 X-1(130-135)$ & 191.7 & 403 & 2.06 & 14.50 & 2.43 & 0.12 & 1.38 & 3.21 & 451 & 75 \\
\hline $27 X-1(106-111)$ & 248.4 & 404 & 2.04 & 13.41 & 2.57 & 0.13 & 1.28 & 2.80 & 478 & 91 \\
\hline $34 X-2(140-150)$ & 307.6 & 420 & 0.65 & 11.91 & 2.40 & 0.05 & 1.04 & 3.80 & 313 & 63 \\
\hline $36 \mathrm{X}-1(140-150)$ & 322.2 & 415 & 0.44 & 7.30 & 2.14 & 0.06 & 0.64 & 2.45 & 297 & 87 \\
\hline $39 X-2(131-141)$ & 352.2 & 410 & 0.70 & 10.27 & 1.92 & 0.06 & 0.91 & 2.71 & 378 & 70 \\
\hline $46 \mathrm{X}-1(140-150)$ & 409.7 & 419 & 0.23 & 4.35 & 1.81 & 0.05 & 0.38 & 1.44 & 302 & 125 \\
\hline
\end{tabular}

Note: Rock-Eval parameters are defined in "Organic Geochemistry" section, Site 679 chapter, and in the "Explanatory Notes."

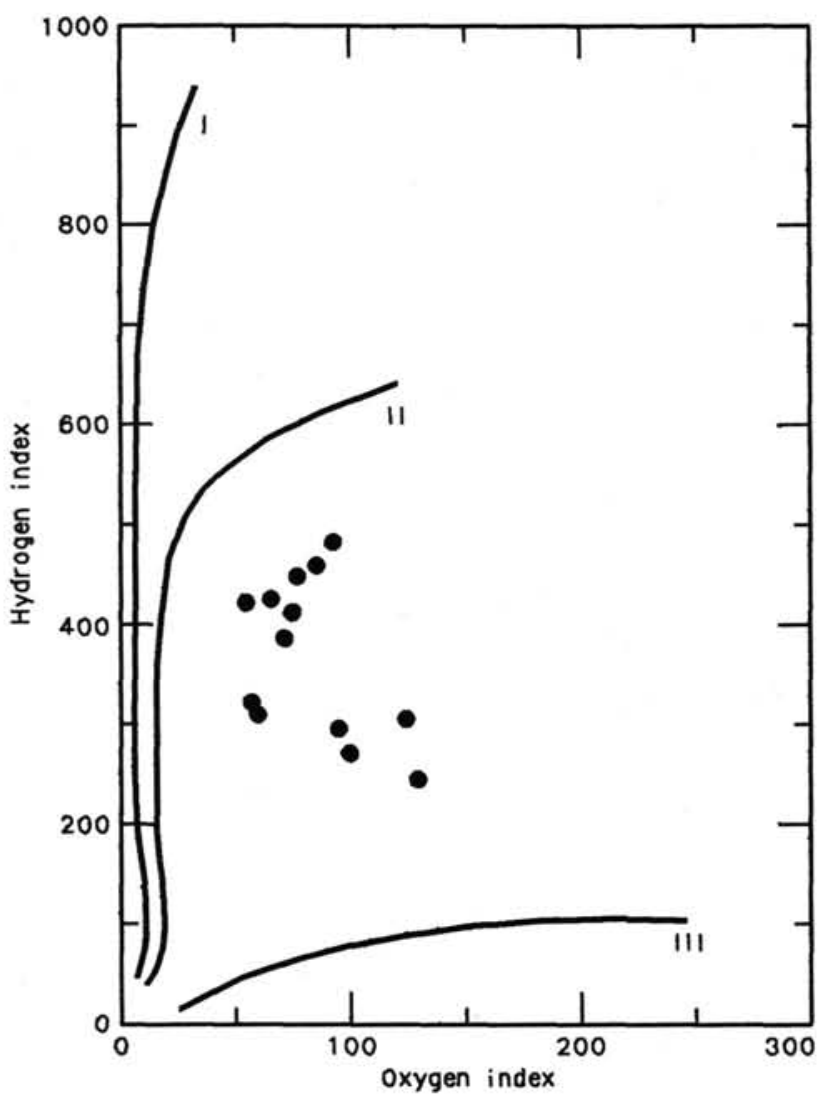

Figure 23. Hydrogen and oxygen indices ( $\mathrm{HI}$ and $\mathrm{OI}$ ) obtained from Rock-Eval analyses of samples from Hole 682A (Table 8) and plotted on a van Krevelen-like diagram.

\section{Chloride and Salinity (Fig. 24 and Table 9)}

Chloride and salinity decrease generally over the depth of the hole with some small but important anomalies near the sediment-water interface.

The following two observations about chloride and salinity distributions were recorded for the first time at Site 682 (Fig. 25). These are closely linked to gas-hydrate formation and dissociation as follows:

1. A chlorinity maximum close to the top of the section, i.e., between about 20 and $55 \mathrm{mbsf}$ of $\sim 560 \mathrm{mmol} / \mathrm{L} \mathrm{Cl}^{-}$, is present, and

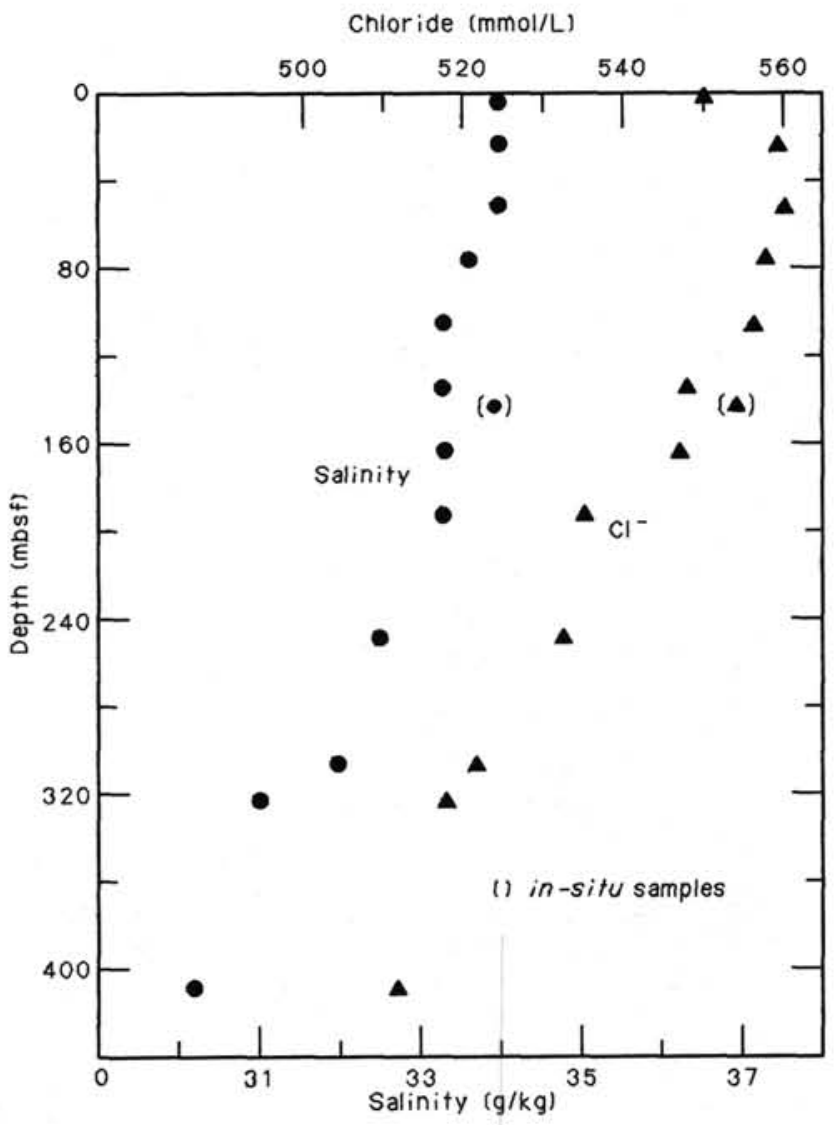

Figure 24. Salinity and chloride profiles for Hole 682A.

2. The in-situ sample 1 , at $142.8 \mathrm{mbsf}$, has higher salinity and chlorinity values than the nearby squeezed-sediment water samples:

\begin{tabular}{|c|c|c|c|}
\hline $\begin{array}{l}\text { Sample } \\
\text { (cm) }\end{array}$ & $\begin{array}{l}\text { Depth } \\
\text { (mbsf) }\end{array}$ & $\underset{(\mathrm{mmol} / \mathrm{L})}{\mathrm{Cl}^{-}}$ & $\begin{array}{c}\text { Salinity } \\
(\mathrm{g} / \mathrm{kg})\end{array}$ \\
\hline A-5X-1, 135-139 & 134.6 & 548.56 & 33.2 \\
\hline In-s & 142.8 & 554.26 & 33.9 \\
\hline $112-682 \mathrm{~A}-18 \mathrm{X}-1,145-150$ & 163.3 & 547.61 & 33.2 \\
\hline
\end{tabular}

As expected, the in-situ sample was less diluted by decomposing gas hydrates than the water from the squeezed wholeround samples. 


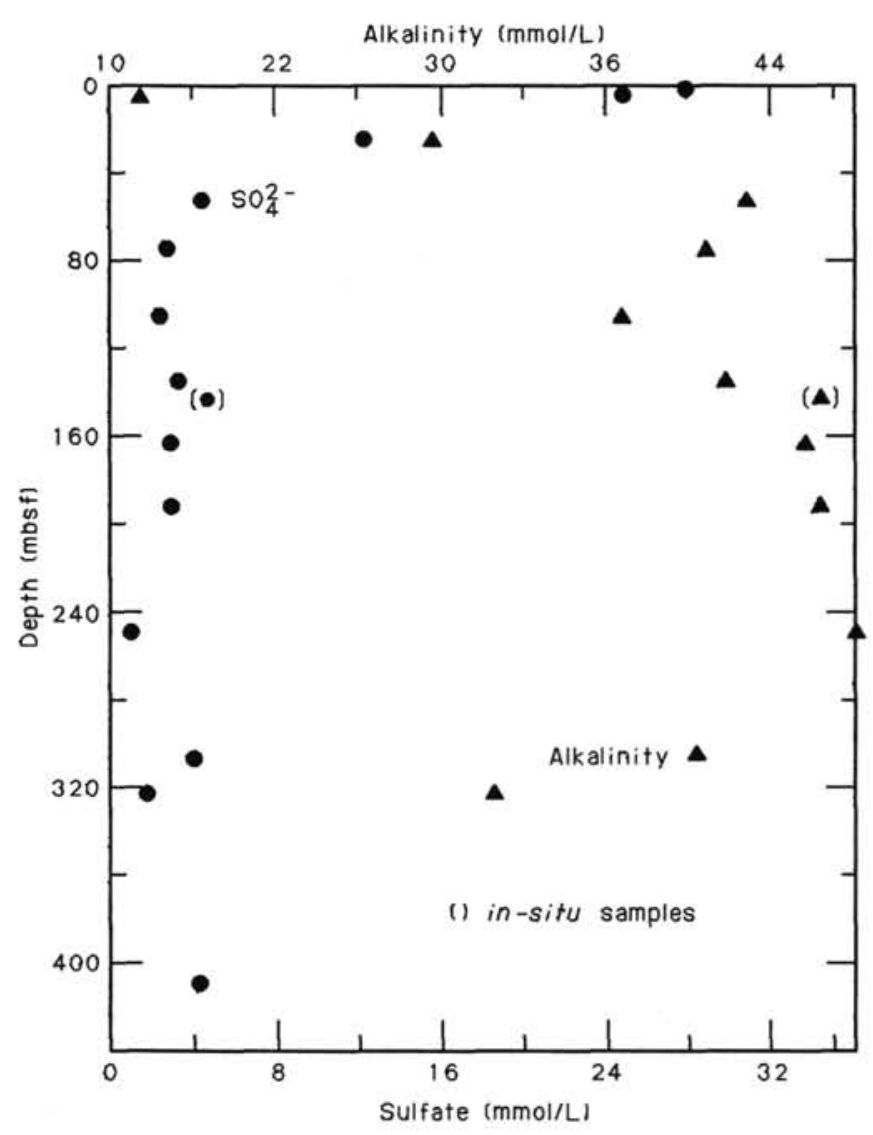

Figure 25 . Sulfate and alkalinity profiles for Hole $682 \mathrm{~A}$.

Between 60 and $\sim 90$ mbsf, salinity and chlorinity values decrease, but between 90 and 220 mbsf, salinity changes are minimal, while chlorinity decreases are significant (from 557 to 535 $\mathrm{mmol} / \mathrm{L}$ ). The small decrease in salinity within this depth interval is related to large alkalinity increases. Below this depth, where alkalinity and ammonia concentrations start to decrease, the observed distinct reduction in salinity from 32.2 to $30.2 \mathrm{~g} /$ $\mathrm{kg}$ is almost entirely controlled by the continuous decreases in $\mathrm{Cl}^{-}$(and primarily $\mathrm{Na}^{+}$).

Thus, we suggest that decomposition of gas hydrates, which provides a progressive dilution "artifact," is primarily responsible for the salinity and chlorinity profiles seen in Fig. 24. Because of this dilution "artifact" at this site, actual decreases in sulfate, phosphate, and magnesium concentrations with depth are less than those observed, and actual increases in alkalinity, ammonia, silica, and calcium are higher than those we observed.

No $\mathrm{Cl}^{-}$enrichments were observed close to the top of the concentration profiles in the waters at Sites 496 and 497 (DSDP Leg 67). Harrison et al. (1982) suggested that the anticipated $\mathrm{Cl}^{-}$enrichment in the residual waters has diminished because of diffusion-advection.

In-situ water samples from the gas-hydrate zone in the Middle America Trench (DSDP Leg 84) also failed to show increases in $\mathrm{Cl}^{-}$concentrations and salinity. Hesse et al. (1985) suggested that the decline in pressure, associated with the in-situ water sampling operation, was large enough to initiate local decomposition of gas hydrates, thus introducing a dilution "artifact" similar to the one we observed in waters from squeezed sediment samples.

\section{Alkalinity and Sulfate (Fig. 25 and Table 9)}

The interstitial-water sulfate profile (Fig. 25) shows rapid sulfate depletion to a rather constant value between 2 and 4

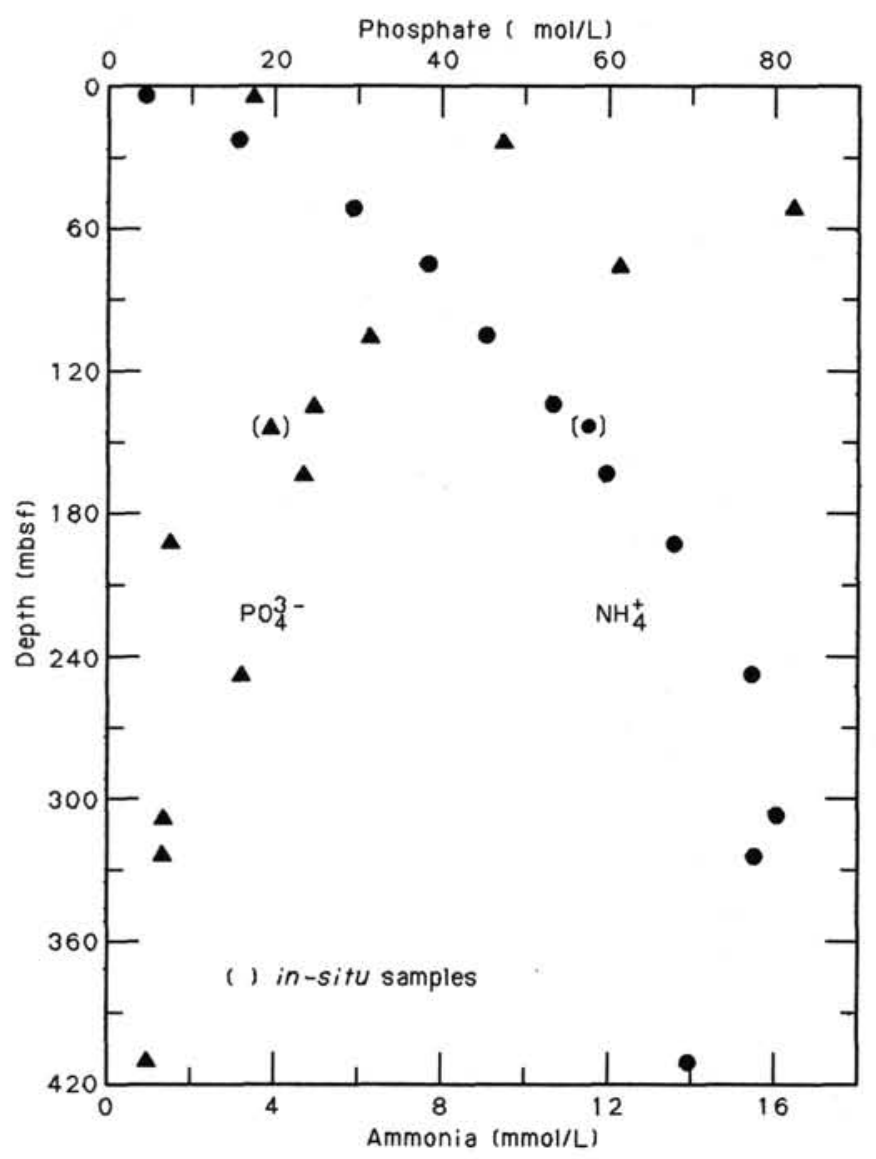

Figure 26. Ammonia and phosphate profiles for Hole 682A.

$\mathrm{mmol} / \mathrm{L}$ from $\sim 70 \mathrm{mbsf}$ to the bottom of the hole. In these somewhat disturbed sediments, slight contamination with drillhole water is probably responsible for the low sulfate values, which never reach zero concentration.

Corresponding to the decreases in sulfate, rapid increases in alkalinity to $48.5 \mathrm{mmol} / \mathrm{L}$ at $248 \mathrm{mbsf}$ are observed. The alkalinity minimum at 105 mbsf is associated with a slumped interval and with minimum amount of $\mathrm{CaCO}_{3}$ of only $1.7 \%$ to $2.1 \%$ (see "Lithostratigraphy" section, this chapter). This alkalinity minimum coincides with a small negative excursion in $\mathrm{Ca}^{2+}$ (see Fig. 28). The observed decrease in alkalinity below $260 \mathrm{mbsf}$ could be related to three simultaneous reactions: carbonate formation, decreasing $\mathrm{NH}_{4}{ }^{+}$concentrations, and $\mathrm{CO}_{2}$ reduction that results in $\mathrm{CH}_{4}$ production. The relative rates of these different reactions vary with depth. As expected, considerable $\mathrm{CH}_{4}$ generation was observed in the low sulfate zone at Site 682.

\section{Ammonia (Fig. 26 and Table 9)}

Ammonia concentrations continuously increase to $310 \mathrm{mbsf}$, where they reach a maximum value of $16 \mathrm{mmol} / \mathrm{L}$. Below this depth, ammonia values decrease. Some of this decline may result from $\mathrm{NH}_{4}^{+}$loss by ion-exchange reactions with silicates, especially with clay minerals, which results in concentration increases in $\mathrm{Mg}^{2+}$ and possibly alkali cations, which we have not as yet analyzed. Much of the $\mathrm{Mg}^{2+}$ maximum seen in Figure 28 may be attributed to this reaction. For example, Gieskes et al. (1982) suggested that the $\mathrm{Mg}^{2+}$ maximum observed at $34 \mathrm{mbsf}$, Site 479 (DSDP Leg 64, Guaymas Basin), was caused by ion exchange with $\mathrm{NH}_{4}^{+}$. As at the previous sites (Sites 679 through 681 ), ammonia peaks at a considerably greater depth than alkalinity and phosphate. 


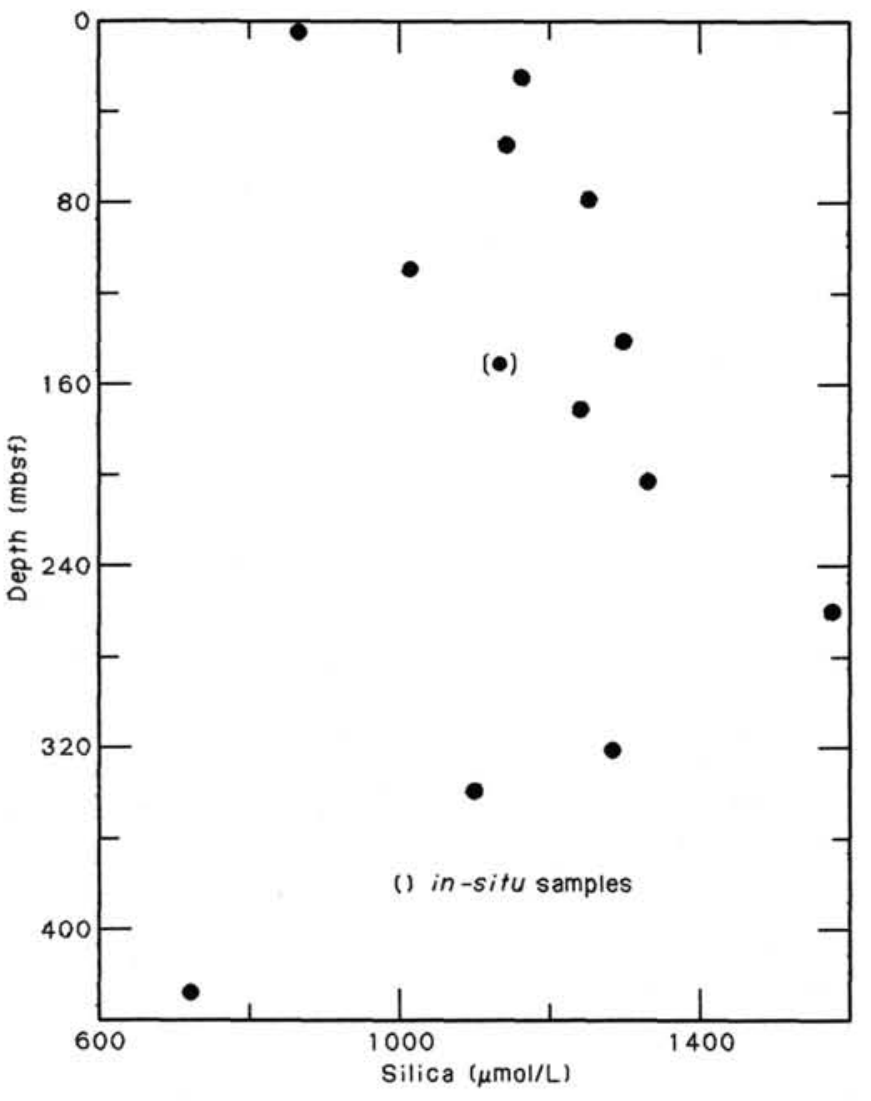

Figure 27. Silica profile for Hole 682A.

\section{Phosphate (Fig. 26 and Table 9)}

Between the sediment/water interface and $52 \mathrm{mbsf}$, rapid increases in phosphate concentrations from 3 to a maximum of $16.5 \mu \mathrm{mol} / \mathrm{L}(2.5 \mu \mathrm{mol} / \mathrm{L} / 10 \mathrm{~m})$ were observed. Below $52 \mathrm{mbsf}$, phosphate concentrations decrease markedly with depth.

Highest phosphate concentrations $(82.15$ and $61.07 \mu \mathrm{mol} / \mathrm{L})$ occur at 52 and 77 mbsf, respectively. This is the exact depth interval where TOC values double from $3.55 \%$ at 24 mbsf to $7.96 \%$ and $7.04 \%$ at 52 and 77 mbsf, respectively (see "Organic Geochemistry" section, this chapter). At these intervals, alkalinity increases to $42.68 \mathrm{mmol} / \mathrm{L}$, and sulfate decreases to 4.4 $\mathrm{mmol} / \mathrm{L}$. Just $30 \mathrm{~m}$ deeper, at $106 \mathrm{mbsf}$, phosphate concentra-

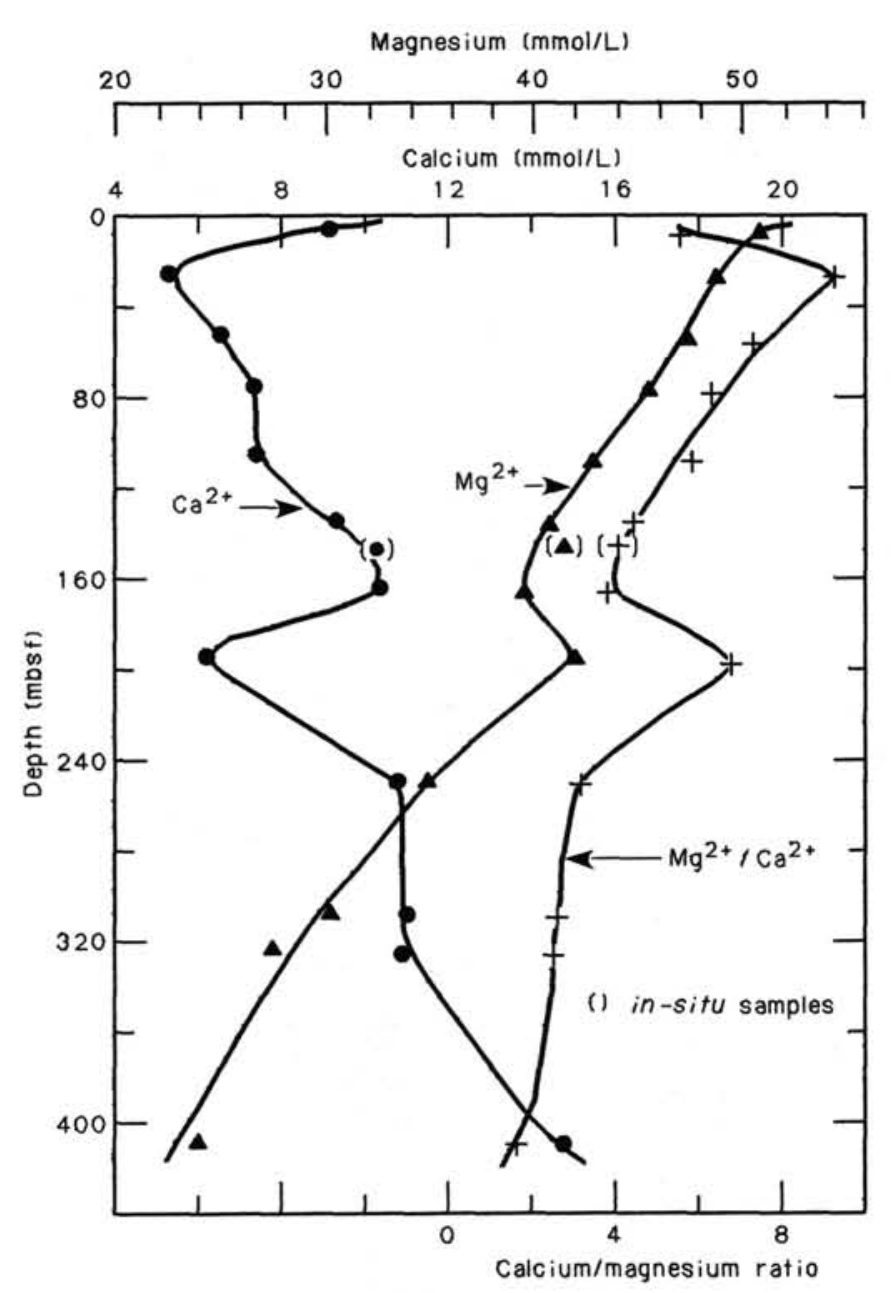

Figure 28. Calcium and magnesium profiles for Hole 682A.

tions and TOC are again considerably lower, $30.85 \mu \mathrm{mol} / \mathrm{L}$ and $2.45 \%$, respectively. Within this depth interval, the age of these sediments is approximately 4.5 to $2.5 \mathrm{~m}$.y. (see "Biostratigraphy" section, this chapter). These sediments were deposited mainly during two considerable higher sea-level stands (Haq et al., 1987). Less dilution with terrigenous matter and/or better preservation of organic matter during high sea-level stands may explain the distinct peaks in TOC and phosphate between about 50 and 80 mbsf.

Table 9. Geochemical data for interstitial water at Site 682 .

\begin{tabular}{|c|c|c|c|c|c|c|c|c|c|c|c|c|}
\hline $\begin{array}{l}\text { Core/section } \\
(\mathrm{cm})\end{array}$ & $\begin{array}{l}\text { Depth } \\
\text { (mbsf) }\end{array}$ & $\mathrm{pH}$ & $\begin{array}{l}\text { Salinity } \\
(\mathrm{g} / \mathrm{kg})\end{array}$ & $\underset{(\mathrm{mmol} / \mathrm{L})}{\mathrm{Cl}^{-}}$ & $\begin{array}{l}\text { Alkalinity } \\
\text { (mmol/L) }\end{array}$ & $\underset{(\mathrm{mmol} / \mathrm{L})}{\mathrm{SO}_{4}^{2-}}$ & $\begin{array}{c}\mathrm{PO}_{4}^{3-} \\
(\mu \mathrm{mol} / \mathrm{L})\end{array}$ & $\begin{array}{c}\mathrm{NH}_{4}^{+} \\
(\mathrm{mmol} / \mathrm{L})\end{array}$ & $\underset{(\mu \mathrm{mol} / \mathrm{L})}{\mathrm{SiO}_{2}}$ & $\underset{(\mathrm{mmol} / \mathrm{L})}{\mathrm{Ca}^{2+}}$ & $\underset{(\mathrm{mmol} / \mathrm{L})}{\mathrm{Mg}^{2+}}$ & $\mathrm{Mg}^{2+} / \mathrm{Ca}^{2+}$ \\
\hline $112-682 \mathrm{~A}-1 \mathrm{H}-3(145-150)$ & 4.5 & 7.7 & 34.0 & 550.46 & 10.60 & 24.7 & 16.80 & 0.81 & 861 & 9.14 & 50.77 & 5.55 \\
\hline $3 \mathrm{H}-3(140-150)$ & 23.7 & 7.3 & 34.0 & 559.95 & 29.60 & 12.2 & 40.69 & 3.03 & 1160 & 5.31 & 48.92 & 9.21 \\
\hline $6 \mathrm{H}-3(140-150)$ & 52.2 & 7.3 & 34.0 & 560.90 & 42.68 & 4.4 & 82.15 & 5.78 & 1137 & 6.45 & 47.54 & 7.37 \\
\hline $9 X-1(106-116)$ & 77.4 & 7.4 & 33.6 & 558.05 & 40.85 & 2.7 & 61.07 & 7.60 & 1252 & 7.18 & 45.46 & 6.33 \\
\hline $12 \mathrm{X}-1(140-150)$ & 105.7 & 7.1 & 33.2 & 557.10 & 36.84 & 2.4 & 30.85 & 8.98 & 1009 & 7.29 & 42.95 & 5.89 \\
\hline $15 X-1(135-139)$ & 134.6 & 6.6 & 33.2 & 548.56 & 41.82 & 3.3 & 24.53 & 10.59 & 1295 & 9.27 & 40.74 & 4.40 \\
\hline In-situ \#1 ${ }^{\circ}$ & 142.8 & $7.1^{\circ}$ & $33.9^{\circ}$ & $554.26^{\circ}$ & $46.42^{\circ}$ & $4.6^{\circ}$ & $18.21^{\circ}$ & $11.45^{\circ}$ & $1130^{\circ}$ & $10.22^{\circ}$ & $41.62^{\circ}$ & 4.07 \\
\hline $112-682 \mathrm{~A}-18 \mathrm{X}-1(145-150)$ & 163.3 & 6.6 & 33.2 & 547.61 & 45.66 & 2.9 & 20.31 & 11.82 & 1237 & 10.30 & 39.79 & 3.86 \\
\hline $21 \mathrm{X}-1(130-135)$ & 191.6 & 7.4 & 33.2 & 535.27 & 46.34 & 2.8 & 6.96 & 13.52 & 1334 & 6.20 & 41.88 & 6.75 \\
\hline In-situ $\# 2^{\circ}$ & 248.0 & $\left(6.8^{\circ}\right)$ & $\left(34.4^{\circ}\right)$ & $\left(549.51^{\circ}\right)$ & $\left(24.50^{\circ}\right)$ & $\left(20.4^{\circ}\right)$ & - & - & - & $\left(12.54^{\circ}\right)$ & $\left(46.97^{\circ}\right)$ & $\left(3.75^{\circ}\right)$ \\
\hline $112-682 \mathrm{~A}-27 \mathrm{X}-1$ (106-111) & 248.4 & 6.7 & 32.5 & 533.38 & 48.41 & 0.5 & 15.40 & 15.37 & 1569 & $10.77^{\prime}$ & 35.08 & 3.23 \\
\hline $34 X-2(140-150)$ & 307.5 & 7.2 & 32.0 & 521.99 & 40.36 & 4.0 & 6.26 & 16.01 & 1288 & 11.01 & 30.13 & 2.74 \\
\hline $36 \mathrm{X}-1(140-150)$ & 322.1 & 7.3 & 31.0 & 518.19 & 32.58 & 1.7 & 6.26 & 15.52 & 1096 & 10.79 & 27.37 & 2.54 \\
\hline $39 \times-2(131-141)$ & 352.1 & 7.3 & $(32.0)$ & (526.73) & $(27.23)$ & (7.3) & - & - & - & (11.68) & (30.49) & $(2.61)$ \\
\hline $46 \mathrm{X}-1(140-150)$ & 409.6 & n.d. & 30.2 & 512.50 & n.d. & 4.2 & 4.15 & 13.89 & 708 & 14.71 & 23.95 & 1.63 \\
\hline
\end{tabular}

Note: ${ }^{*}=$ in-situ water samples; ()$=$ sample contaminated by drill-hole seawater; $\mathrm{n} . \mathrm{d} .=$ not determined because of small sample volume recovered. 
Despite high TOC values $(1.5 \%$ to $7.9 \%)$ and rather slow sedimentation rates, no phosphorites were observed at this site. The more oxygenated bottom water at a depth of $3790 \mathrm{~m}$ and extensive bioturbation may have prevented the formation of francolite at this site. However, if francolite did form, it would be diluted by the high sedimentation rate at this site. The high alkalinity value of $42.68 \mathrm{mmol} / \mathrm{L}$ at the depth of maximum phosphate concentration also may have prevented significant francolite formation. Authigenic calcite and dolomite most probably formed instead.

\section{Silica (Fig. 27 and Table 9)}

As was the case at all previous sites during this leg, silica values rapidly increased with depth. In the uppermost $20 \mathrm{~m}$, silica values reach saturation levels with respect to opal-A solubility. Below this depth, the interstitial waters are even supersaturated with respect to opal-A, and inorganic opal-A may precipitate in these sediments. The observed decrease in silica concentrations, below about $270 \mathrm{mbsf}$, coincides with a lithological change from the more diatomaceous lithologic Units I and II to the more terrigenous Unit III (see "Lithostratigraphy" section, this chapter). Silica and ammonia maxima occur at the same depth (Figs. 27 and 26, respectively). Slightly elevated $\mathrm{pH}$ values associated with higher $\mathrm{NH}_{4}{ }^{+}$(and alkalinity) concentrations could be responsible for the depth coincidence of the $\mathrm{NH}_{4}{ }^{+}$and $\mathrm{SiO}_{2}$ maxima.

\section{Calcium and Magnesium (Fig. 28 and Table 9)}

As at Sites 680 and 681 , the shallowest samples analyzed at 4.5 mbsf have $\mathrm{Ca}^{2+}$ and $\mathrm{Mg}^{2+}$ concentrations lower than seawater, attesting to early diagenesis involving carbonate minerals.

The interstitial water $\mathrm{Ca}^{2+}$ profile shows a systematic increase with depth, with two pronounced minima at $\sim 24$ and at $\sim 192$ mbsf and one more subtle minimum at $106 \mathrm{mbsf}$. The $\mathrm{Mg}^{2+}$ profile shows a systematic decrease with depth, with one significant maximum at $\sim 192$ mbsf. However, this maximum is less pronounced than the corresponding $\mathrm{Ca}^{2+}$ minimum; indeed, the molar $\mathrm{Mg}^{2+} / \mathrm{Ca}^{2+}$ ratio displays a distinct maximum of 6.75 at this depth. At $24 \mathrm{mbsf}$ the $\mathrm{Mg}^{2+} / \mathrm{Ca}^{2+}$ ratio reaches a value of 9.2 , which is common in sabkha environments. The $\mathrm{Mg}^{2+}$ maximum, at $192 \mathrm{mbsf}$, does not exactly coincide with the $\mathrm{NH}_{4}^{+}$maximum. However, it does occur in the zone of high $\mathrm{NH}_{4}^{+}$concentrations, where ammonia concentrations reach $>13.5 \mathrm{mmol} / \mathrm{L}$. Ion-exchange reactions of $\mathrm{NH}_{4}^{+}$for $\mathrm{Mg}^{2+}$ in silicate minerals may be partially responsible for the $\mathrm{Mg}^{2+}$ maximum.

$\mathrm{Ca}^{2+}$ and $\mathrm{Mg}^{2+}$ together with the alkalinity and sulfate profiles suggest a general sequence of carbonate diagenesis as follows:

1. Rapid sulfate reduction and alkalinity production promote rapid calcite precipitation, as indicated by the first $\mathrm{Ca}^{2+}$ minimum (in Fig. 28, $\mathrm{Ca}^{2+}$ minimum at $23.7 \mathrm{mbsf}$ coincides with maximum $\mathrm{CaCO}_{3}$ content of $26.4 \%$ ) and slow formation of dolomite.

2. Consequently, the $\mathrm{Mg}^{2+} / \mathrm{Ca}^{2+}$ ratio increases sharply, dolomite formation is enhanced, and dolomitization of the authigenic (and biogenic) calcite is initiated.

3. This reaction continues and is responsible for the observed concentration increases in $\mathrm{Ca}^{2+}$ and decreases in $\mathrm{Mg}^{2+}$ with depth. A similar sequence of events occurs near $192 \mathrm{mbsf}$. Besides ion exchange with $\mathrm{NH}_{4}^{+}$, the origin of the $\mathrm{Mg}^{2+}$ maximum at this depth is as yet unclear. It may be related partially to volcanic-glass alteration reactions. Dolomitization reactions could continue throughout the depth interval cored. The rate of the reaction should decrease significantly with depth as the $\mathrm{Mg}^{2+} / \mathrm{Ca}^{2+}$ ratio decreases below 2 to 1.63 at $\sim 400$ mbsf.

\section{Contamination of $\mathbf{I n}$-Situ Interstitial-Water Samples}

We suspected admixture of seawater from the drill hole in several in-situ samples. The overflow volume in in-situ sample 2 , at $248.0 \mathrm{mbsf}$, was very high $(\sim 1120 \mathrm{~mL})$. The increase in pressure from the minimum was not steep, but rather gradual at first (see Fig. 29 at $\sim 3000$ s). The data in Table 9 clearly indicate contamination from drill-hole seawater: salinity, $\mathrm{Cl}^{-}, \mathrm{SO}_{4}^{2-}$, $\mathrm{Ca}^{2+}$, and $\mathrm{Mg}^{2+}$ concentrations are considerably higher, while the corresponding alkalinity value is $50 \%$ of the value in interstitial waters from adjacent squeezed whole-round samples. In organic carbon-rich sediments within and below the sulfate-reduction zone, sulfate concentrations become an extremely sensitive indicator for the purity of in-situ and of squeezed interstitial waters. For example, at Site 682 , in-situ sample 2 was deployed in the middle of the sulfate-depleted and methane-generation zones; the sulfate concentration we determined is 20.4 $\mathrm{mmol} / \mathrm{L}$ vs. 0.5 to $2.8 \mathrm{mmol} / \mathrm{L}$ in the immediate vicinity (Table 9). Similarly, alkalinity provides an excellent signal for seawater contamination. Admixed seawater should decrease the alkalinity value of interstitial waters in such organic carbon-rich sediments. Accordingly, the interstitial water squeezed from the sediment at 352.1 mbsf (Sample 112-682A-39X-2, 131-141 cm) is also contaminated but to a lesser degree than in-situ sample 2 . Sulfate concentration is $7.3 \mathrm{mmol} / \mathrm{L}$, compared with the value of $1.7 \mathrm{mmol} / \mathrm{L}$ in the closest sample analyzed (112-682A-36X-1, $140-150 \mathrm{~cm}$ ) at $322.1 \mathrm{mbsf}$. Sample 112-682A-39X-2, 131-141 $\mathrm{cm}$, was composed of a closely knit mixture of small, angular, indurated, hard sediment pieces and drilling slurry. We were unable to separate completely the sediment pieces from the drilling slurry during the sample preparation procedure before the squeezing operation. Subsequently, this sample and in-situ sample 2 were not analyzed for $\mathrm{NH}_{4}^{+}, \mathrm{PO}_{4}^{3-}$, and $\mathrm{SiO}_{2}$.

In-situ water sample 2, which contains admixed drill-hole seawater, shows similar enrichments in salinity and chlorinity relative to adjacent squeezed sediment samples, as in-situ sample 1 .

An unambiguous distinction between (1) pristine residual water from gas-hydrate formation and (2) admixed drill-hole seawater cannot be made on the basis of increased values of chlorinity (and salinity) alone. Similarly, sulfate concentrations should also show an increase in both water types. However, alkalinity and ammonia data should provide the necessary definitive distinctions between these two water types in the sulfate-reduction and methane-production zones. In water type (1), the

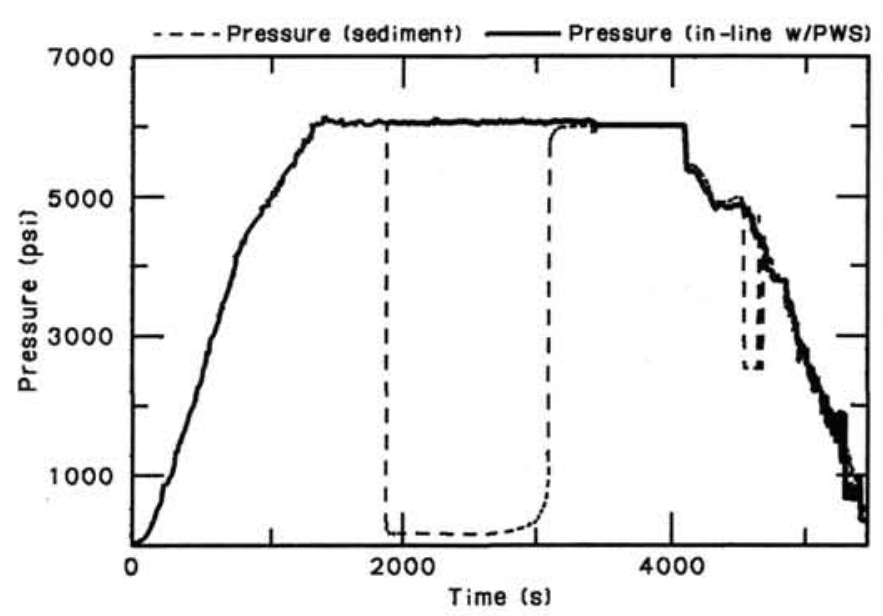

Figure 29. Diagram of pressure vs. time for in-situ water sample 1. 
residual water from gas-hydrate formation and alkalinity and ammonia concentrations should be higher than in adjacent interstitial waters from squeezed sediment samples, as observed in Figures 26 and 27 for in-situ sample 1. In water type (2), the admixture of drill-hole seawater should decrease the alkalinity and ammonia values, as seen in in-situ sample 2 .

At Site 682, two in-situ samples were collected from Hole $682 \mathrm{~A}$ at 230.2 and 363.2 mbsf. Unfortunately, both were contaminated from drill-hole seawater, as shown in Table 10. In this table the data obtained from neighboring interstitial waters from squeezed sediment samples are compared with the data from insitu samples. Values for standard seawater (IAPSO) are shown as well. The in-situ samples have higher salinity, sulfate, chlorinity, $\mathrm{Ca}^{2+}$ and $\mathrm{Mg}^{2+}$, and lower alkalinity values relative to the squeezed waters, as expected from mixing with seawater. Apparently, in more indurated zones at depths greater than about $200 \mathrm{mbsf}$ at this site, the penetration of the probe into the sediments "cracks" the formation, allowing some drill-hole water to penetrate and mix with the in-situ formation waters.

The percentage of contamination by drill-hole seawater can be calculated as follows:

$$
a S W+b I W=\text { measured value. }
$$

Using the conservative anion $\mathrm{Cl}^{-}$in the in-situ sample 1:

$$
559 a+485.7 b=515.12,
$$

where

$$
559=\mathrm{Cl}^{-} \text {concentration in seawater, }
$$

$a=$ proportion of admixed seawater,

$485.7=$ expected $\mathrm{Cl}^{-}$concentration in a pristine in-situ sample at this depth,

$b=$ proportion of interstitial water $\mathrm{Cl}^{-}$, and

$515.12=$ measured $\mathrm{Cl}^{-}$concentration in in-situ sample.

Similarly for $\mathrm{SO}_{4}^{2-}$,

$$
\begin{aligned}
28.9 a+3.54 b=15.70, & \\
a=\frac{15.70-3.54 b}{28.9}= & 0.543-0.1225 b, \\
559(0.543-0.1225 b)+485.7 b & =515.12, \\
303.54-68.47 b+485.7 b & =515.12, \\
417.23 b & =211.58, \\
b & =0.5071, \\
a & =0.4929, \text { and }
\end{aligned}
$$

$0.4929 \times 100=49.3 \%$ contamination by drill-hole water.

For in-situ sample 2:

$$
559 a+373.35 b=508.44\left(\text { for } \mathrm{Cl}^{-}\right),
$$

$$
\begin{aligned}
28.9 a+0.04 b=17.17 \text { (for } & \left.\mathrm{SO}_{4}^{2-}\right), \\
a=0.5941-0.0014 b, & \\
559(0.5941-0.0014 b)+373.35 b & =508.44, \\
373.35 b-0.774 b & =508.44- \\
372.58 b & =176.34, \\
b & =0.4733, \\
a & =0.5267, \text { and }
\end{aligned}
$$

$0.5267 \times 100=52.7 \%$ contamination by drill-hole water.

\section{PALEOMAGNETICS}

\section{Introduction}

At Site 682 the first $86 \mathrm{~m}$ (down to Core 112-682A-10X) had a magnetization strong enough to be measured with the spinner magnetometer on board the Resolution. Poor core recovery below Core 112-682A-6H caused us to abandon sampling at Core $112-682 \mathrm{~A}-10 \mathrm{X}$.

\section{Results}

\section{Hole $682 A$}

Figure 30 shows the declination, inclination, and intensity values vs. depth for the samples measured. With the exception of one sample at around $30 \mathrm{mbsf}$, all of the upper $40 \mathrm{~m}$ of section is normally magnetized. We believe it deposited during the Brunhes Chron. The Brunhes-Matuyama boundary probably occurs somewhere between 40 and 49 mbsf (between Cores 112$682 \mathrm{~A}-5 \mathrm{X}$ and $112-682 \mathrm{~A}-6 \mathrm{H}$ ). Samples from between 40 and 48 mbsf are lacking. We could not assign ages to numerous polarity reversals below 50 mbsf because of the large gaps in core recovery.

\section{PHYSICAL PROPERTIES}

Physical-properties measurements at Site 682 were performed on split cores, generally at an interval of one every two sections $(3 \mathrm{~m})$ in good quality APC cores and, wherever possible, in $\mathrm{XCB}$ cores. The recovery and the quality of the recovered material were poor at this site, particularly in the XCB cores. Therefore, large gaps occur in the physical-properties data, particularly in the lower $200 \mathrm{~m}$ of the hole.

\section{Index Properties}

The index properties measured at Site 682 include water content (presented as a percentage of dry sample weight), porosity, bulk density, and grain density (Table 11). The methods used to measure the index properties at Site 682 were the same as those specified in the "Explanatory Notes" (this volume). We calculated index properties using an assumed salinity of $35 \% 0$.

Figure 31 illustrates the downhole trends in water content and porosity with depth and lithology for this site. Figure 32 shows the bulk-density data obtained from samples from split cores

Table 10. Comparisons between interstitial-water chemical data from squeezed sediment samples and in-situ samples contaminated with drill-hole water at Hole 682A.

\begin{tabular}{lccccccc}
\hline \multicolumn{1}{c}{$\begin{array}{c}\text { Core-section } \\
(\mathrm{cm})\end{array}$} & $\begin{array}{c}\text { Depth } \\
(\mathrm{mbsf})\end{array}$ & $\begin{array}{c}\text { Salinity } \\
(\mathrm{g} / \mathrm{kg})\end{array}$ & $\begin{array}{c}\text { Alkalinity } \\
(\mathrm{mmol} / \mathrm{L})\end{array}$ & $\begin{array}{c}\mathrm{SO}_{4}^{2-} \\
(\mathrm{mmol} / \mathrm{L})\end{array}$ & $\begin{array}{c}\mathrm{Cl}^{-} \\
(\mathrm{mmol} / \mathrm{L})\end{array}$ & $\begin{array}{c}\mathrm{Ca}^{2+} \\
(\mathrm{mmol} / \mathrm{L})\end{array}$ & $\begin{array}{c}\mathrm{Mg}^{2+} \\
(\mathrm{mmol} / \mathrm{L})\end{array}$ \\
\hline $112-682 \mathrm{~A}-24 \mathrm{X}-1(69-74)$ & 211.9 & 32.0 & 68.37 & 4.42 & 488.41 & 7.25 & 33.03 \\
In-situ \#1 & 230.2 & 33.5 & 33.66 & 15.70 & 515.12 & 8.90 & 42.02 \\
$112-682 \mathrm{~A}-27 \mathrm{X}-1(123-128)$ & 240.9 & 31.3 & 57.90 & 3.10 & 483.64 & 7.18 & 29.74 \\
$112-682 \mathrm{~A}-39 \mathrm{X}-2(140-150)$ & 356.6 & 29.4 & 35.50 & 0.0 & 473.15 & 9.19 & 23.16 \\
In-situ \#2 & 363.2 & 32.5 & 18.16 & 17.17 & 508.44 & 12.13 & 39.84 \\
112-682A-43X-2 (140-150) & 393.6 & 28.2 & 26.26 & 0.95 & 474.10 & 10.79 & 21.48 \\
Seawater (IAPSO) & & $\sim 35$ & $\sim 2.5$ & 28.9 & 559 & 10.55 & 53.99 \\
\hline
\end{tabular}




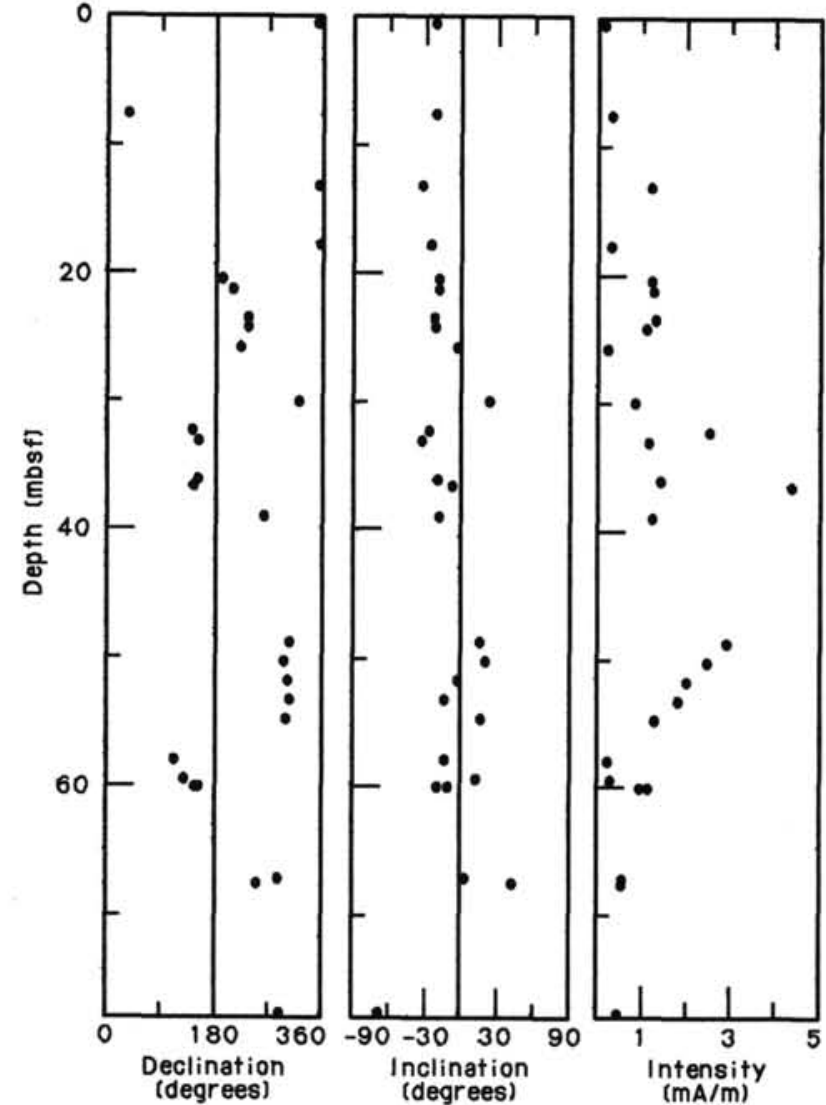

Figure 30. Declination, inclination, and magnetic intensity for Hole 682A. The Brunhes/Matuyama boundary is believed to occur somewhere between Cores 112-682A-5X and 112-682A-6H.

and from the GRAPE plots. Core sections were run through the GRAPE as time allowed, with three or four sections of each core usually completed. Figure 32 shows the excellent correlation between GRAPE data and bulk-density values obtained from index-property samples. The peaks that occur in GRAPE data for APC cores probably result from occasional thin sand layers. In the XCB cores, the values of bulk density obtained using the GRAPE are slightly lower than the values from the samples, i.e., the samples gave values that corresponded to the peak values from GRAPE data. We expected this trend for XCB cores because drilling slurry and sediment disturbance would result in lower bulk densities in the GRAPE data.

The water content values within the upper $100 \mathrm{~m}$ of Hole $682 \mathrm{~A}$ range from low values of $80 \%-85 \%$ to high values of $165 \%-180 \%$. This corresponds to lithologic Subunits IA and IB. The areas of increasing and decreasing water contents in these units have a similar cyclic behavior to values from previous sites (see Site 681 chapter). The porosity and bulk-density data in the upper $100 \mathrm{~m}$ of Hole $682 \mathrm{~A}$ also show this cyclic trend. These porosity values vary from a low of $66 \%$ to a high of $83 \%$ in Subunits IA and IB. Bulk-density values vary from a low of 1.31 to a high of almost $1.8 \mathrm{~g} / \mathrm{cm}^{3}$.

Subunit IC, located at 105 mbsf, lies above a slump zone with a dolomite zone at its base. This unit corresponds with a decline in water content to $72 \%$ and a decrease in porosity to $67 \%$. The bulk density increases to $1.64 \mathrm{~g} / \mathrm{cm}^{3}$, while the dolomite zone was observed as a distinct spike in the GRAPE data, with values of bulk density greater than $2.0 \mathrm{~g} / \mathrm{cm}^{3}$ (Fig. 32).

Few data points occur in litholgic Subunit IA; however, in Subunit IB the index properties appear to follow a more linear trend than in the upper $100 \mathrm{~m}$ of sediment by showing behavior
Table 11. Summary of index properties data at Site 682

\begin{tabular}{|c|c|c|c|c|c|}
\hline $\begin{array}{l}\text { Core/section } \\
\text { interval } \\
\text { (cm) }\end{array}$ & $\begin{array}{l}\text { Depth } \\
\text { (mbsf) }\end{array}$ & $\begin{array}{c}\text { Water } \\
\text { content } \\
\text { (\% dry wt) }\end{array}$ & $\begin{array}{c}\text { Porosity } \\
(\%)\end{array}$ & $\begin{array}{c}\text { Bulk } \\
\text { density } \\
\left(\mathrm{g} / \mathrm{cm}^{3}\right)\end{array}$ & $\begin{array}{c}\text { Grain } \\
\text { density } \\
\left(\mathrm{g} / \mathrm{cm}^{3}\right)\end{array}$ \\
\hline $112-682 \mathrm{~A}-1 \mathrm{H}-1,60$ & 0.60 & 152.61 & 80.77 & 1.37 & 2.55 \\
\hline $1 \mathrm{H}-3,65$ & 3.65 & 80.10 & 69.44 & 1.60 & 2.65 \\
\hline $1 \mathrm{H}-5,78$ & 6.78 & 111.95 & 76.20 & 1.48 & 2.54 \\
\hline $2 \mathrm{H}-2,73$ & 12.03 & 119.40 & 77.31 & 1.46 & 2.55 \\
\hline $2 \mathrm{H}-4,85$ & 15.15 & 84.21 & 68.60 & 1.54 & 2.47 \\
\hline $2 \mathrm{H}-6,76$ & 18.06 & 85.58 & 71.84 & 1.60 & 2.64 \\
\hline $3 \mathrm{H}-2,71$ & 21.51 & 109.06 & 75.71 & 1.49 & 2.47 \\
\hline $3 \mathrm{H}-4,59$ & 24.39 & 101.56 & 74.40 & 1.51 & 2.56 \\
\hline $3 \mathrm{H}-6,47$ & 27.27 & 109.24 & 75.40 & 1.48 & 2.38 \\
\hline $4 \mathrm{H}-2,71$ & 31.01 & 168.02 & 81.83 & 1.34 & 2.16 \\
\hline $4 \mathrm{H}-6,33$ & 36.63 & 162.92 & 80.48 & 1.33 & 2.08 \\
\hline $5 X-1,92$ & 39.22 & 157.29 & 80.82 & 1.35 & 2.33 \\
\hline $6 \mathrm{H}-2,83$ & 50.13 & 105.45 & 72.99 & 1.46 & 2.25 \\
\hline $6 \mathrm{H}-4,64$ & 52.94 & 135.02 & 79.29 & 1.41 & 2.19 \\
\hline $7 X-2,59$ & 59.39 & 102.19 & 75.54 & 1.53 & 2.47 \\
\hline $9 X-1,42$ & 76.72 & 177.34 & 81.49 & 1.31 & 2.12 \\
\hline $10 X-1,80$ & 86.60 & 178.62 & 83.24 & 1.33 & 2.13 \\
\hline $11 X-1,65$ & 95.95 & 139.17 & 78.28 & 1.38 & 2.23 \\
\hline $12 X-1,95$ & 105.75 & 72.38 & 67.09 & 1.64 & 2.47 \\
\hline $12 X-2,74$ & 107.04 & 75.30 & 67.05 & 1.60 & 2.51 \\
\hline $13 \mathrm{X}-1,95$ & 115.25 & 76.12 & 68.48 & 1.62 & 2.49 \\
\hline $13 X-3,36$ & 117.66 & 73.59 & 65.56 & 1.58 & 2.47 \\
\hline $14 X-1,100$ & 124.80 & 115.93 & 73.88 & 1.41 & 2.22 \\
\hline $14 X-2,114$ & 126.44 & 105.76 & 73.40 & 1.46 & 2.31 \\
\hline $18 X-2,24$ & 163.54 & 109.68 & 73.82 & 1.45 & 2.33 \\
\hline $18 \mathrm{X}-1,95$ & 162.75 & 112.23 & 75.22 & 1.46 & 2.40 \\
\hline $20 X-1,68$ & 181.48 & 91.47 & 69.88 & 1.50 & 2.38 \\
\hline $20 X-2,50$ & 182.80 & 118.47 & 75.92 & 1.43 & 2.40 \\
\hline $21 X-1,84$ & 191.14 & 102.19 & 72.12 & 1.46 & 2.24 \\
\hline $22 X-1,66$ & 200.46 & 87.97 & 70.69 & 1.55 & 2.30 \\
\hline $22 X-2,58$ & 201.88 & 94.89 & 72.10 & 1.52 & 2.31 \\
\hline $23 X-1,86$ & 210.16 & 101.10 & 74.66 & 1.52 & 2.44 \\
\hline $24 X-1,62$ & 219.42 & 66.45 & 52.43 & 1.35 & 2.31 \\
\hline $34 \mathrm{X}-1,102$ & 305.62 & 62.68 & 63.22 & 1.68 & 2.51 \\
\hline $34 X-3,47$ & 308.07 & 61.91 & 62.90 & 1.69 & 2.56 \\
\hline $35 X-1,16$ & 311.36 & 58.57 & 61.20 & 1.70 & 0.00 \\
\hline $35 X-3,53$ & 314.73 & 34.82 & 50.73 & 2.01 & 2.60 \\
\hline $36 X-1,67$ & 321.37 & 35.36 & 51.08 & 2.00 & 2.61 \\
\hline $37 X-2,20$ & 331.90 & 43.44 & 54.07 & 1.83 & 2.55 \\
\hline $38 \mathrm{X}-1,56$ & 340.26 & 28.00 & 42.60 & 2.00 & 2.57 \\
\hline $40 X-3,30$ & 362.00 & 28.88 & 43.65 & 2.00 & 2.52 \\
\hline $47 X-1,138$ & 419.08 & 33.14 & 45.89 & 1.89 & 2.53 \\
\hline
\end{tabular}

that would be expected for a normally consolidating sediment. Water-content values decrease slightly, from $118 \%$ at $183 \mathrm{mbsf}$ to $66 \%$ at $220 \mathrm{mbsf}$. The porosities decrease very slightly, and the bulk-density values show an increase of 1.43 to $1.52 \mathrm{~g} / \mathrm{cm}^{3}$ over the same depth interval. The index-property sample taken at 219 mbsf provided much lower values of water content, porosity, and bulk density. A closer look at the lithology at this depth may explain this phenomenon. Alternatively, we can attribute this to a poor sample or error in measurement. The GRAPE data do not reflect this sudden decrease in bulk density.

The limited data in lithologic Unit III show a further decrease with depth of the values of water content and porosity, as would be expected for these more lithified sediments. The bulkdensity values, as calculated from index-properties samples and recorded with the GRAPE, show a marked increase with depth. We obtained only one sample in lithologic Unit IV because core disturbance prevented good quality GRAPE data. However, the values obtained for the index properties of the sample at 419 mbsf are similar to the last samples from lithologic Unit III.

\section{Compressional-Wave Velocity}

We did not use the Hamilton Frame to measure the velocities of the sediments at Site 682. The $P$-wave logger (PWL), which is run in conjunction with the GRAPE, provides more continuous velocity data than the Hamilton Frame for sediments cored using the APC. The Hamilton Frame is used more effectively on 


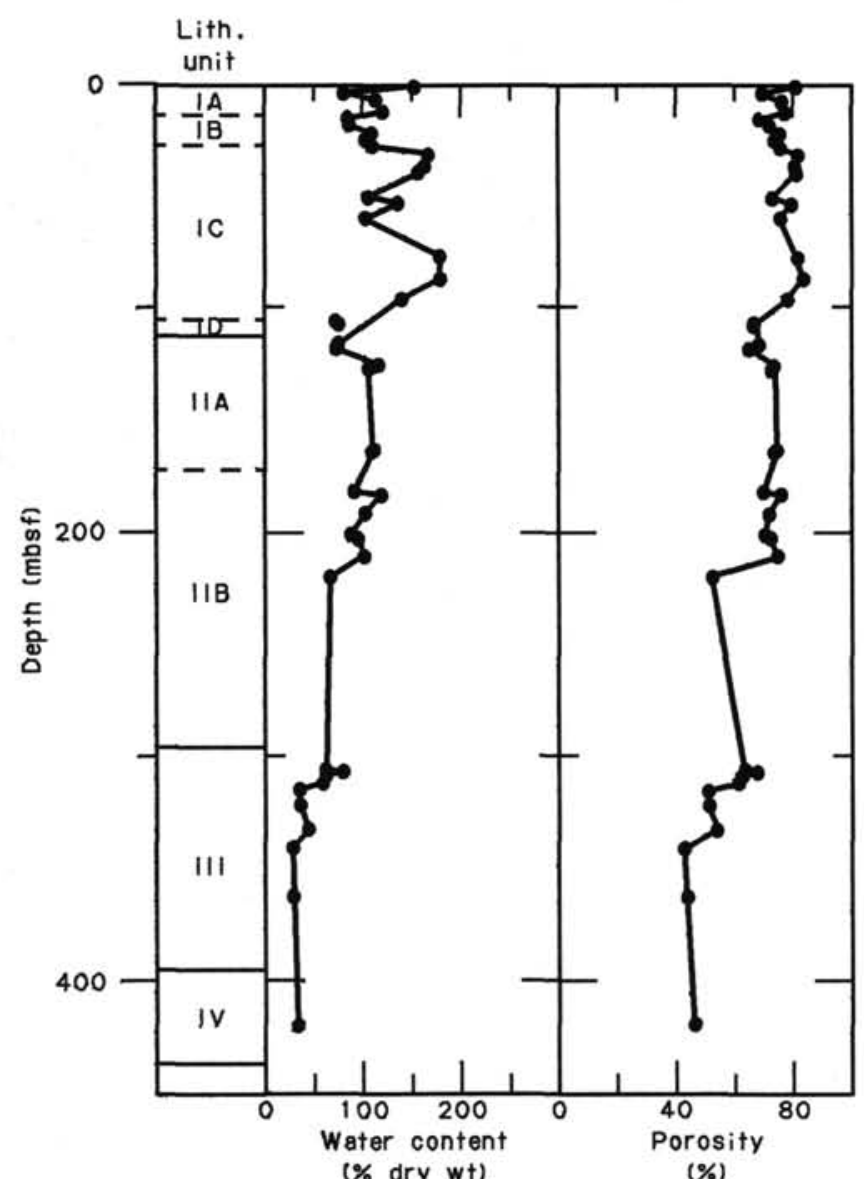

Figure 31. Water content and porosity profiles for Site 682 . Lithologic units are shown schematically.

cubes cut from the XCB "biscuits," where PWL data might not be reliable. However, at this site the XCB material was not intact enough to allow samples to be taken for the Hamilton Frame.

Velocity data from the PWL were reduced manually by selecting reasonable values of velocity from shipboard printouts. The PWL velocity values are shown in Figure 33 . For previous sites of Leg 112, we did not have enough time to reduce the $P$ wave data and velocities to obtain values of signal amplitude during the run. We studied data about signal strength and discovered that the $P$-wave data obtained from XCB cores cold not be considered as indicating velocity through sediments. While watching several of the runs in progress, we observed that values of velocity in excess of $1.6 \mathrm{~km} / \mathrm{s}$ were being plotted even when there were voids inside the core liner. A study of the reduced data showed that the amplitude of the signal through most the sediments in the XCB cores approached zero. Therefore, the velocities we obtained in these cores are derived from noise in the system and could not be used.

Figure 33 shows the $P$-wave-velocity data for the upper 115 $\mathrm{m}$ of the sediment. In general, $P$-wave data followed the trends observed from bulk-density data. We attributed peaks in the data to denser layers of sand. The velocity values generally increase with depth, which indicates a consolidating sequence, but also are considerably scattered in relation to variations of index-property data.

\section{Vane Shear Strength}

The undrained vane shear strength measurements for Site 682 were performed with the Wykham Farrance vane apparatus. Values obtained for peak undrained vane shear strength are pre-

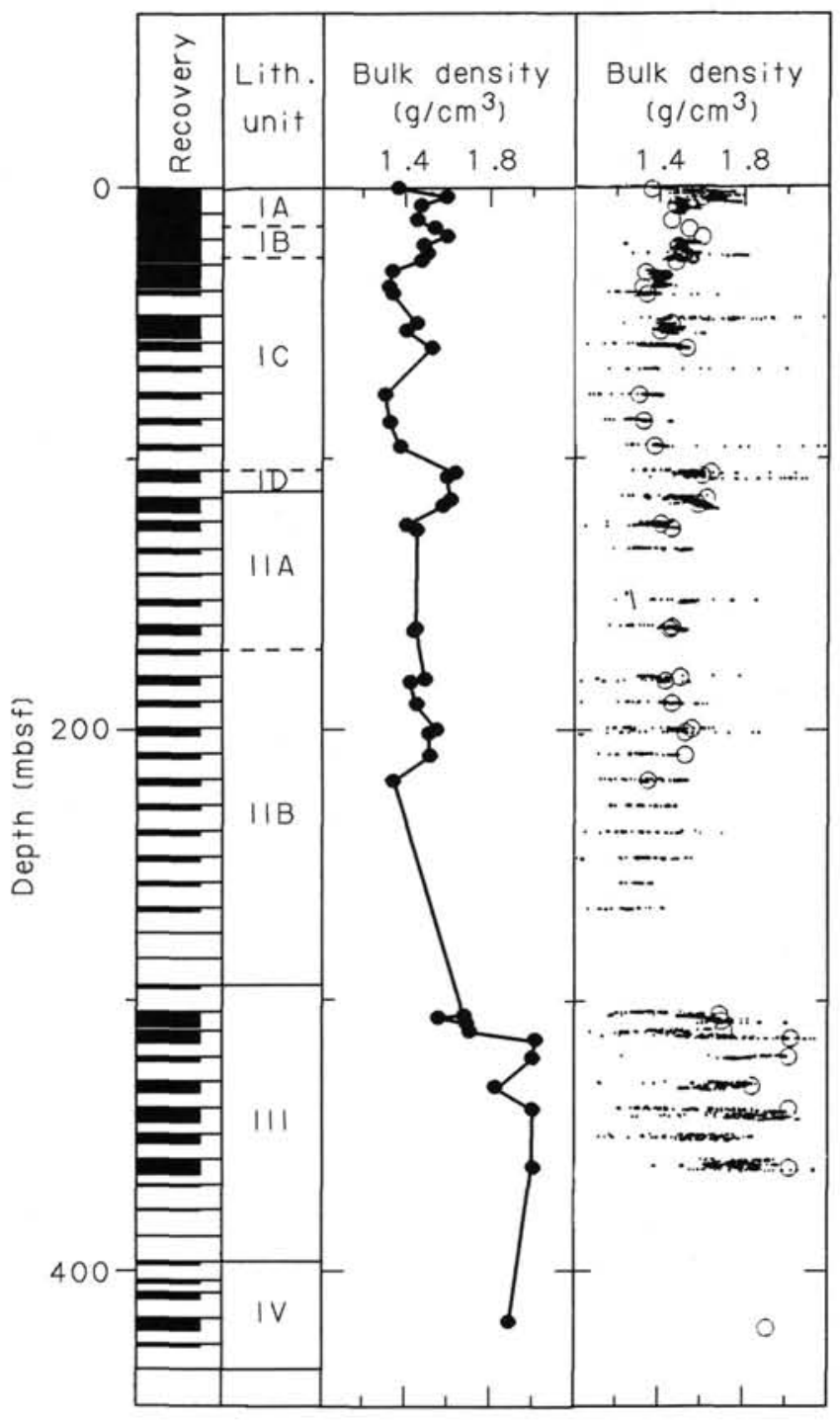

Figure 32. Sample bulk-density measurements and GRAPE bulk-density profile for Site 682 . Core recovery and lithologic units are shown schematically.

sented in Table 12 and are shown vs. depth below seafloor in Figure 34. The strength data of lithologic Subunits IA and IB are considerably scattered, with a minimum peak shear strength of $17.5 \mathrm{kPa}$ at $0.58 \mathrm{mbsf}$ and a maximum of $225 \mathrm{kPa}$ at 53 mbsf. Although this scatter may be attributed to cyclic sedimentation that might have occurred at this site, there is a trend of rapidly increasing strength with depth.

A sharp decrease in peak vane shear strength values (corresponding to the slump zone) occurs in Subunit IC. The values of peak vane shear strength obtained for Subunit II decrease rapidly with depth, from a value of $204 \mathrm{kPa}$ at $118 \mathrm{mbsf}$ to a value of $128 \mathrm{kPa}$ at $163.5 \mathrm{mbsf}$.

A comparison of vane-shear-strength and water-content profiles showed that in many cases high water contents correspond to high vane shear strengths. In normally consolidating sediments, water contents decrease and shear strengths increase with increasing depth below seafloor. However, at Site 682, the water contents and shear strengths show several, often parallel, highs and lows. This anomaly probably is owing to the fabric of these diatom-rich sediments. The interlocking diatom framework apparently results in the high vane shear strengths observed. 


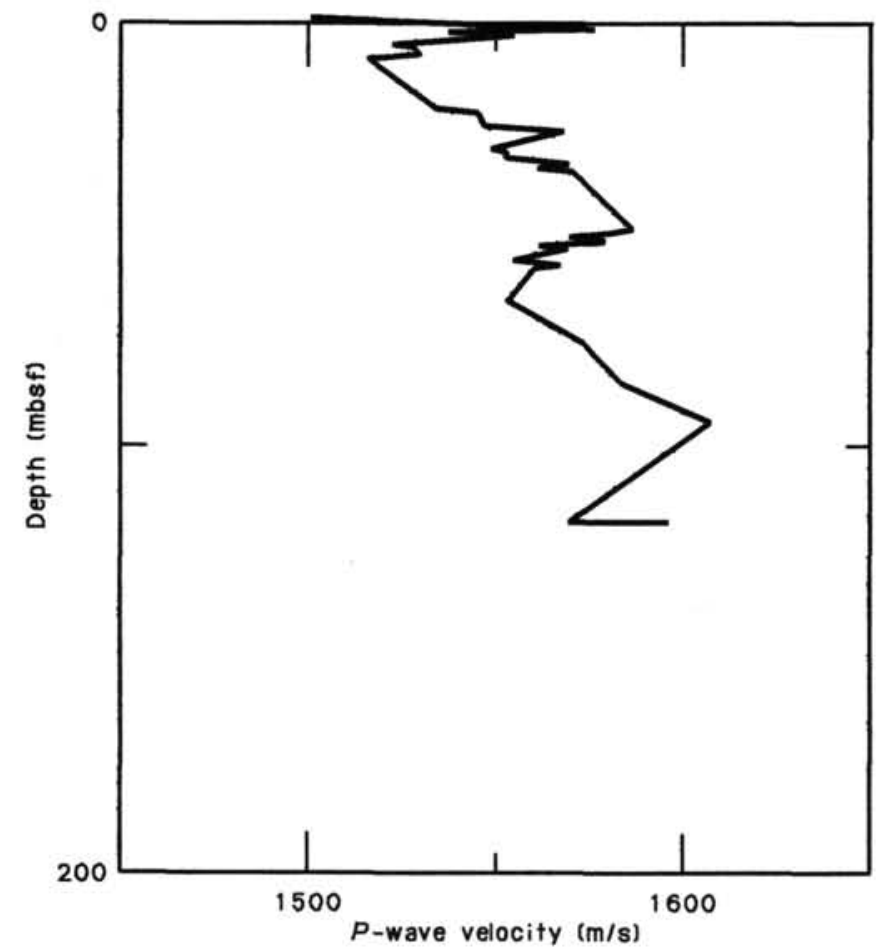

Figure 33. Compressional-wave velocity profile for Site 682 .

Table 12. Summary of vane shear strength data at Site 682 .

\begin{tabular}{crr}
\hline $\begin{array}{c}\text { Core/section } \\
\text { interval }(\mathrm{cm})\end{array}$ & $\begin{array}{r}\text { Depth } \\
\text { (mbsf) }\end{array}$ & $\begin{array}{c}\text { Peak velocity } \\
\text { (kPa) }\end{array}$ \\
\hline $112-682 \mathrm{~A}-1 \mathrm{H}-1,58$ & 0.58 & 17.53 \\
$1 \mathrm{H}-3,63$ & 3.63 & 35.52 \\
$1 \mathrm{H}-5,75$ & 6.75 & 43.37 \\
$2 \mathrm{H}-2,78$ & 12.08 & 80.28 \\
$2 \mathrm{H}-4,82$ & 15.12 & 66.90 \\
$2 \mathrm{H}-6,73$ & 18.03 & 64.59 \\
$3 \mathrm{H}-2,77$ & 21.57 & 64.59 \\
$3 \mathrm{H}-4,64$ & 24.44 & 77.05 \\
$3 \mathrm{H}-6,52$ & 27.32 & 125.49 \\
$4 \mathrm{H}-2,77$ & 31.07 & 88.09 \\
$4 \mathrm{H}-4,74$ & 34.04 & 212.02 \\
$4 \mathrm{H}-6,31$ & 36.61 & 163.50 \\
$5 \mathrm{X}-1,88$ & 39.18 & 63.46 \\
$6 \mathrm{H}-2,83$ & 50.13 & 192.61 \\
$6 \mathrm{H}-4,65$ & 52.95 & 224.72 \\
$7 \mathrm{X}-2,59$ & 59.39 & 111.98 \\
$12 \mathrm{X}-1,96$ & 105.76 & 89.59 \\
$12 \mathrm{X}-2,74$ & 107.04 & 100.04 \\
$13 \mathrm{X}-1,96$ & 115.26 & 101.53 \\
$13 \mathrm{X}-3,37$ & 117.67 & 203.81 \\
$15 \mathrm{X}-1,89$ & 134.19 & 188.13 \\
$17 \mathrm{X}-1,115$ & 153.45 & 153.93 \\
$18 \mathrm{X}-2,24$ & 163.54 & 128.27 \\
\hline
\end{tabular}

Note: $\mathrm{H}=$ hydraulic piston; $\mathrm{X}=$ extended-core barrel.

\section{Thermal Conductivity}

Thermal conductivity was measured by the needle-probe method on every section down to $191 \mathrm{mbsf}$, except in apparently disturbed cores. Below this depth, the samples were too disturbed by drilling for reliable measurements.

The values obtained are presented in Table 13 and Figure 35. Data is greatly scattered in lithologic Unit I. This seems to caused mainly by the cyclic behavior of the index properties be-

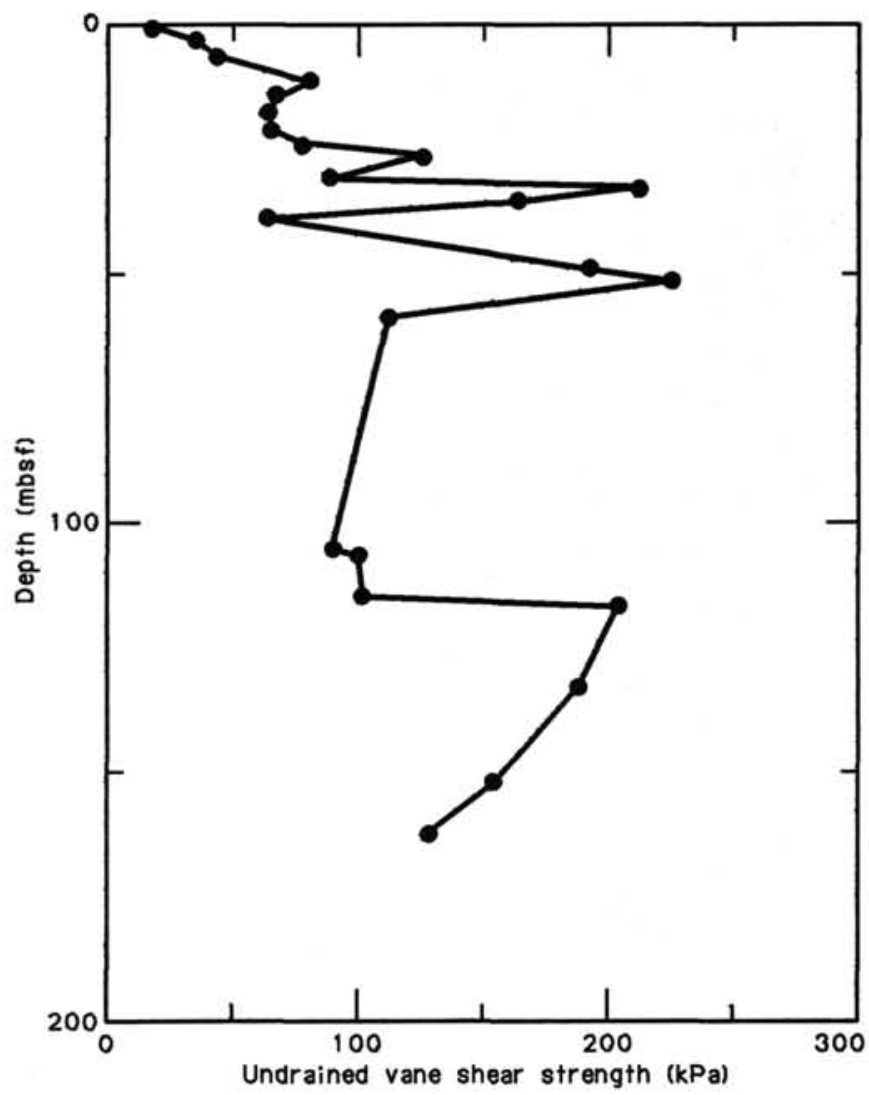

Figure 34. Peak undrained vane shear strength profile for Site 682.

Table 13. Results of thermal conductivity measurements using two different methods.

\begin{tabular}{rcc}
\hline & \multicolumn{2}{c}{$\begin{array}{c}\text { Thermal conductivity } \\
(\mathrm{W} / \mathrm{m} \cdot \mathrm{K})\end{array}$} \\
Core/section & normal method & end method \\
\hline $112-682 \mathrm{~A}-3 \mathrm{H}-4$ & 0.983 & 0.977 \\
$4 \mathrm{H}-2$ & 0.762 & 0.765 \\
$4 \mathrm{H}-3$ & 0.805 & 0.847 \\
$4 \mathrm{H}-4$ & 0.816 & 0.731 \\
$4 \mathrm{H}-5$ & 0.779 & 0.746 \\
$6 \mathrm{H}-2$ & 0.806 & 0.869 \\
$6 \mathrm{H}-3$ & 0.867 & 0.774 \\
$6 \mathrm{H}-4$ & 0.809 & 0.765 \\
$6 \mathrm{H}-5$ & 0.907 & 0.901 \\
\hline
\end{tabular}

cause the variation of thermal conductivity correlates well with the variation of water content and bulk density (Figs. 31 and 32). For example, the low values around 80 mbsf can be explained by the high water content. The high values near 20 mbsf may correspond to the high carbonate content.

Thermal conductivity is relatively uniform in lithologic Unit II, about $0.85 \mathrm{~W} / \mathrm{m} \cdot \mathrm{K}$. The low values between 180 and 200 mbsf are questionable because cores were more or less disturbed. This hypothesis may be supported by the observation that the GRAPE bulk density is lower than the bulk density of the samples.

We compared two different measurement methods on Site 682 samples: (1) "the normal method" where the needle probes are inserted perpendicular to the core axis before splitting, and (2) the probes are inserted from the ends of the split sections parallel to the core axis. The latter method is called "the end method" in the following discussion. The needle-probe tech- 


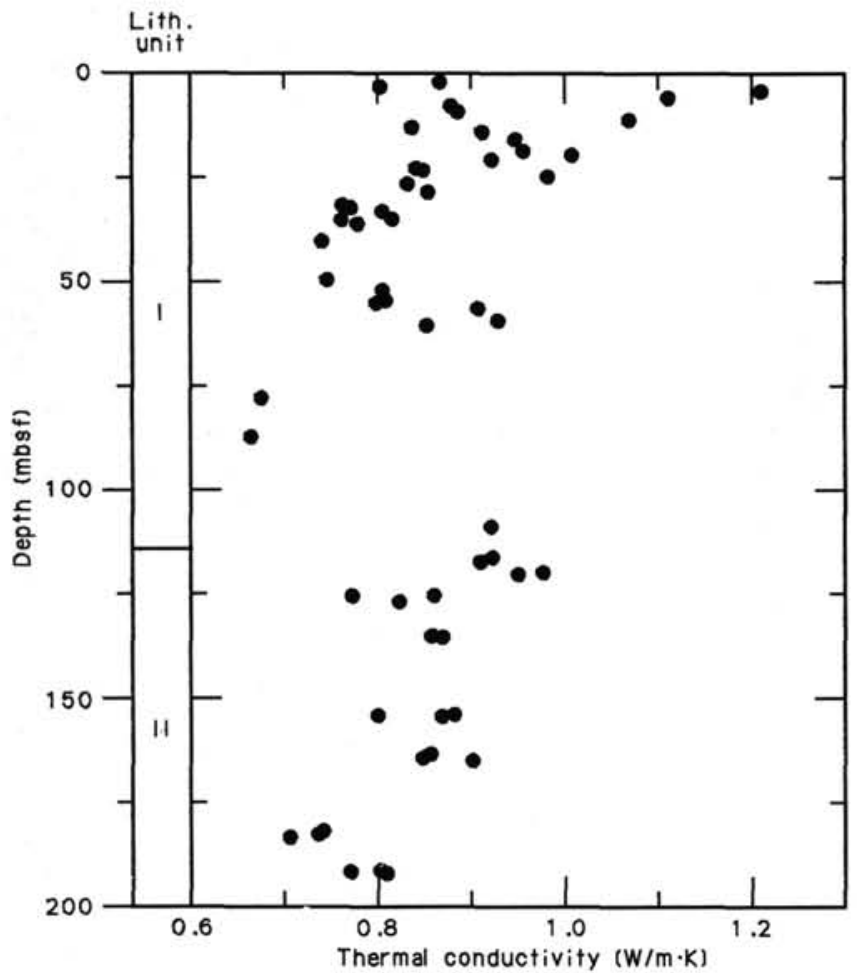

Figure 35 . Thermal conductivity vs. depth below seafloor for Hole $682 \mathrm{~A}$.

nique assumes that the sample is an infinite medium. Because the available volume of the sample was smaller using the the end method, the sample was heated and measured for $3 \mathrm{~min}$, while it was measured for 6 min with the normal method.

We compared the two methods using 11 data points. Two data points were eliminated because significant core disturbance was found after splitting the cores. Our results are shown in Table 14 and Figure 36 . The broken line in Figure 36 represents the case where the two methods agree precisely. The difference between the values by the two methods is smaller than 0.05 $\mathrm{W} / \mathrm{m} \cdot \mathrm{K}$ in most cases and smaller than $0.1 \mathrm{~W} / \mathrm{m} \cdot \mathrm{K}$ for all the data. This suggests that the end method will work to an acceptable level of precision.

However, some limitations exist when using the end method. The end part of the sample may experience disturbance when cut. Water may be added to the sample during splitting with a saw, and the thermal conductivity of sediment is significantly affected by water content. On the other hand, some water may be lost after splitting while waiting for the thermal equilibrium. Considering these problems, we believe that measurements with the end method should be conducted only when the core must be opened as soon as possible.

\section{Discussion}

The physical-property data for the upper $100 \mathrm{~m}$ of sediment indicate the oscillatory behavior that we observed at previous sites. Cycles of sediment deposition under different sea-level conditions could account for these variations in index-property and vane-shear-strength data. The high water contents and porosities reflect the high diatom content, almost $40 \%$ over most of the upper $100 \mathrm{~m}$ of sediment. The generally low velocities result from the high water contents of the sediment.

Lithologic Subunit IC, described as a slump zone, is marked by a decrease in values of water content, porosity, and vane shear strength. The bulk-density values increase in this area. The
Table 14. Thermal conductivity profile for Site 682.

\begin{tabular}{|c|c|c|}
\hline $\begin{array}{l}\text { Core/section } \\
\text { interval }(\mathrm{cm})\end{array}$ & $\begin{array}{l}\text { Depth } \\
\text { (mbsf) }\end{array}$ & $\begin{array}{c}\text { Thermal conductivity } \\
(\mathrm{W} / \mathrm{m} \cdot \mathrm{K})\end{array}$ \\
\hline $112-682 \mathrm{~A}-1 \mathrm{H}-1,70$ & 0.70 & 0.867 \\
\hline $1 \mathrm{H}-2,70$ & 2.20 & 0.803 \\
\hline $1 \mathrm{H}-3,70$ & 3.70 & 1.209 \\
\hline $1 \mathrm{H}-4,70$ & 5.20 & 1.110 \\
\hline $1 \mathrm{H}-5,70$ & 6.70 & 0.878 \\
\hline $1 \mathrm{H}-6,70$ & 8.20 & 0.886 \\
\hline $2 \mathrm{H}-1,70$ & 10.50 & 1.069 \\
\hline $2 \mathrm{H}-2,70$ & 12.00 & 0.837 \\
\hline $2 \mathrm{H}-3,70$ & 13.50 & 0.911 \\
\hline $2 \mathrm{H}-4,70$ & 15.00 & 0.946 \\
\hline $2 \mathrm{H}-6,40$ & 17.70 & 0.956 \\
\hline $2 \mathrm{H}-6,120$ & 18.50 & 1.008 \\
\hline $3 \mathrm{H}-1,70$ & 20.00 & 0.922 \\
\hline $3 \mathrm{H}-2,70$ & 21.50 & 0.842 \\
\hline $3 \mathrm{H}-3,70$ & 22.00 & 0.848 \\
\hline $3 \mathrm{H}-4,10$ & 23.90 & 0.983 \\
\hline $3 \mathrm{H}-5,10$ & 25.40 & 0.832 \\
\hline $3 \mathrm{H}-6,10$ & 26.90 & 0.854 \\
\hline $4 \mathrm{H}-2,10$ & 30.40 & 0.762 \\
\hline $4 \mathrm{H}-2,70$ & 31.00 & 0.772 \\
\hline $4 \mathrm{H}-3,10$ & 31.90 & 0.805 \\
\hline $4 \mathrm{H}-4,10$ & 33.40 & 0.816 \\
\hline $4 \mathrm{H}-4,70$ & 34.00 & 0.762 \\
\hline $4 \mathrm{H}-5,10$ & 34.90 & 0.779 \\
\hline $5 X-1,70$ & 39.00 & 0.740 \\
\hline $6 \mathrm{H}-1,52$ & 48.32 & 0.746 \\
\hline $6 \mathrm{H}-2,138$ & 50.68 & 0.806 \\
\hline $6 \mathrm{H}-4,70$ & 53.00 & 0.809 \\
\hline $6 \mathrm{H}-4,140$ & 53.70 & 0.799 \\
\hline $6 \mathrm{H}-5,138$ & 55.18 & 0.907 \\
\hline $7 X-1,70$ & 58.00 & 0.928 \\
\hline $7 X-2,40$ & 59.20 & 0.852 \\
\hline $9 X-1,50$ & 76.80 & 0.676 \\
\hline $10 X-1,70$ & 86.50 & 0.664 \\
\hline $12 X-3,20$ & 108.00 & 0.921 \\
\hline $13 \mathrm{X}-1,118$ & 115.48 & 0.923 \\
\hline $13 X-2,53$ & 116.33 & 0.910 \\
\hline $13 X-4,20$ & 119.00 & 0.977 \\
\hline $13 X-4,60$ & 119.40 & 0.950 \\
\hline $14 X-1,40$ & 124.20 & 0.860 \\
\hline $14 \mathrm{X}-1,120$ & 125.00 & 0.773 \\
\hline $14 X-2,60$ & 125.90 & 0.823 \\
\hline $15 X-1,70$ & 134.00 & 0.858 \\
\hline $15 X-1,110$ & 134.40 & 0.869 \\
\hline $17 X-1,80$ & 153.10 & 0.881 \\
\hline $17 \mathrm{X}-1,105$ & 153.35 & 0.862 \\
\hline $17 X-1,130$ & 153.60 & 0.868 \\
\hline $18 \mathrm{X}-1,100$ & 162.80 & 0.856 \\
\hline $18 X-2,30$ & 163.60 & 0.848 \\
\hline $18 X-2,80$ & 164.10 & 0.901 \\
\hline $20 \mathrm{X}-1,34$ & 181.14 & 0.742 \\
\hline $20 \mathrm{X}-1,118$ & 181.98 & 0.736 \\
\hline $20 X-2,54$ & 182.74 & 0.706 \\
\hline $21 X-1,35$ & 190.65 & 0.803 \\
\hline $21 X-1,72$ & 191.02 & 0.771 \\
\hline $21 X-1,111$ & 191.41 & 0.810 \\
\hline
\end{tabular}

physical-property data in lithologic Units II and III indicate a normally consolidating sequence, with decreasing water contents and porosities and increasing bulk densities and shear strengths.

\section{GEOPHYSICS}

\section{Seismic Records}

Site 682 was selected to sample the age and nature of the basement at the front of the Peruvian margin. In the primary seismic record on which the selection was made, basement appeared to be covered by only a thin sequence of sediment, thus providing an opportunity to recover basement lithology with a minimum of drilling. However, before we drilled we noted that the reflections of relatively higher amplitude $(0.4 \mathrm{~s}$ below seafloor), thought to represent basement, were underlain by a thin 


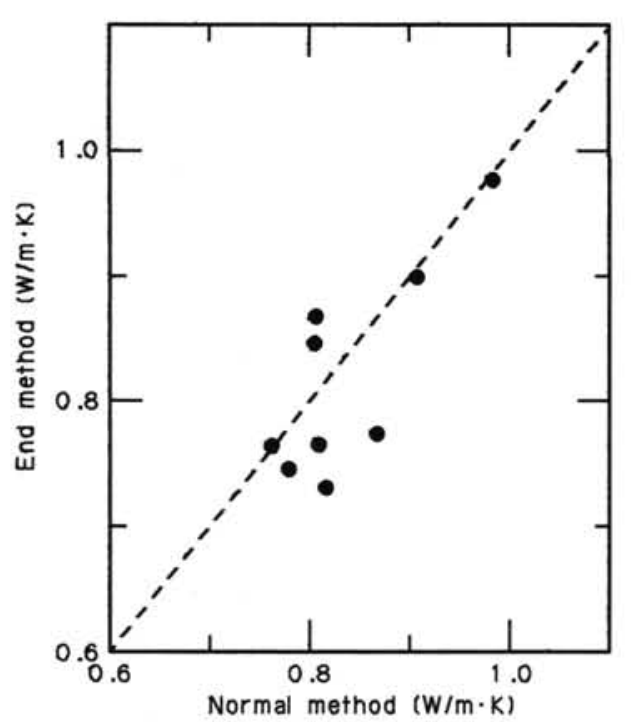

Figure 36. Comparison of the two different methods for measuring thermal conductivity; for details see text.

zone containing reflections of lower amplitude, perhaps from a poorly reflective sediment sequence ( 0.4 to $0.6 \mathrm{~s}$ below seafloor) (Fig. 37). Drilling proved this to be correct, and we discovered that rather than $400 \mathrm{~m}$, some $650 \mathrm{~m}$ of sediment covered the basement. Because Hole $682 \mathrm{~A}$ was not completed to basement, a key tie point between lithology and seismic reflections remained unrecovered. We needed such a tie point to refine our few sonic velocity measurements and to provide precise correlation between lithostratigraphy and seismic stratigraphy. Our experience at this site demonstrates the folly of selecting a site using obscured seismic data. In reprocessed data, basement targets were clearly imaged at depths equivalent to those verified by our unsuccessful drilling.

Site 682 was located on record 13, a migrated 24-fold CDP line paralleling the dip of the slope (Fig. 37). At about $1600 \mathrm{~m}$ upslope, this site intersected by record 18 , an unmigrated 24 fold CDP line paralleling the strike of the slope. Although record 13 contains no obvious coherent reflections across the site, it does show some broken reflections of increased amplitude about $0.4 \mathrm{~s}$ below the seafloor (Fig. 37). Seismic images with broken and diffracted reflections suggest intense tectonic deformation. This interpretation seemed to conflict with the lithologies of the upper $250 \mathrm{~m}$ of core, where relatively few deformed, massive, undisrupted beds were observed. By carefully tracing phases across adjacent traces of the seismic record, a series of low-amplitude reflections were discerned. These are shown in a line drawing (Fig. 37). By tracing each reflection this way, we took care to avoid the uncollapsed diffractions that obscured the record locally. By similar examination, the main reflections in record 13 were located in record 18 (not shown here). By increasing in the scaling parameters (amplitude, swing, bias) during processing of the records, we should improve the display.

Two reflective horizons are noted in the line drawing (Fig. 37): (A) the base of an upper sequence with fair continuity and amplitude (at $0.15 \mathrm{~s}$ ) and (B) the top of the sequence assumed to be basement (at $0.4 \mathrm{~s}$ ). A sonic velocity of $1540 \mathrm{~m} / \mathrm{s}$ (see "Physical Properties" section, this chapter) places A at $115 \mathrm{~m}$ or about $10 \mathrm{~m}$ below the Miocene/Pliocene contact (see "Biostratigrphy" section, this chapter) and at a massive slump (see "Lithostratigraphy" section, this chapter). Assuming a sonic velocity of 1650 $\mathrm{m} / \mathrm{s}$ for the interval between A and B yields a depth of about $360 \mathrm{~m}$ for B, which is within reasonable limits to correlate this horizon with the interval of poor recovery thought to contain gravel. The gravel corresponds to a hiatus in which the Oligocene is missing. The lithologic character of such a boundary is consistent with that of the seismic feature.

In the area of Site 682, the structure in the seismic record of the upper sediment sequence is typical of a slope deposit, as is the corresponding lithology of the section drilled (see "Lithostratigraphy" section, this chapter). At this site, the top of the basement was not imaged, although about $5 \mathrm{~km}$ upslope a basement surface was observed. This basement surface can be followed in seismic record 13 across the Lima Basin to beneath the shelf. In records adjacent to 13 , the basement is visible across much of the lower slope where the site is located. Sections of records Peru 1 and Shell 1017 show that the slope deposits continue across the lower slope to within $10-15 \mathrm{~km}$ of the trench axis. The basement seen beneath the shelf appears continuous to the lower slope as well. The structure seen in these adjacent lines is probably also present in record 13 .

\section{Heat Flow}

\section{Temperature Measurements}

We did not attempt temperature measurements during APC coring at Site 682 because APC coring was possible only to Core $112-682 \mathrm{~A}-4 \mathrm{H}$ and in $112-682 \mathrm{~A}-6 \mathrm{H}$ due to very stiff sediments. We deployed the APC tool twice with the pore-water sampler after Cores 112-682A-15X (142.8 mbsf) and 112-682A26X (247.3 mbsf), when we measured pore water and pressure. We did not use the T-probe for these measurements because the temperature sensor and the pressure sensor could not be incorporated in the pore-water sampler at the same time.

Figures 38 and 39 show the temperature records conducted with the APC tool. These are typical examples of the temperature records that resulted when the APC tool was attached to the pore-water sampler. From these records, we observed that the lower limits of the true formation temperature are $5.0^{\circ} \mathrm{C}$ in both cases.

\section{Discussion}

We estimated that the bottom-water temperature at Site 682 was $1.7^{\circ} \mathrm{C}$ from the oceanographic data. When combined with the temperature data obtained by the other method, the temperature recorded by the APC tool should be corrected to $0.2 \mathrm{~K}$ (see "Explanatory Notes," this volume). Therefore, the minimum temperature at $142.8 \mathrm{mbsf}$ is $4.8^{\circ} \mathrm{C}$, and the minimum temperature gradient between the seafloor and $142.8 \mathrm{mbsf}$ is $22 \times 10^{-3} \mathrm{~K} / \mathrm{m}$.

Thermal-conductivity measurements were performed to 191 mbsf at Site 682. After correcting the obtained values for the temperature and pressure effects, the thermal resistance between the seafloor and $142.8 \mathrm{mbsf}$ was calculated to be $182.6 \mathrm{~m}^{2} \cdot \mathrm{K} /$ W. As the minimum temperature difference for this depth range is $3.1^{\circ} \mathrm{C}$, the minimum heat flow was about $17 \mathrm{~mW} / \mathrm{m}^{2}$.

This value can be compared with two other observations. One is the result of surface heat-flow measurements during the site-survey cruise for Leg 112 (Yamano, 1986). Heat flow measured about $20 \mathrm{~km}$ northwest of Site 682 was $49 \mathrm{~mW} / \mathrm{m}^{2}$. This station is probably located at an equivalent position to Site 682 on the trench slope. Thus, we expected that heat flow values at Site 682 would not be much different from $49 \mathrm{~mW} / \mathrm{m}^{2}$.

The other observation is the heat flow values estimated from the gas-hydrate bottom simulating reflector (BSR). A prominent BSR was seen in the vicinity of Site 682 on a multichannel seismic reflection line (record 13). Heat flow can be estimated from the depth of such BSRs using the phase diagram of gas hydrates and the inferred density and thermal conductivity of sediments (Yamano et al., 1982). The subbottom depth of the BSR nearest Site 682 (about $8 \mathrm{~km}$ away) is $0.58 \mathrm{~s}$ in two-way traveltime. As- 

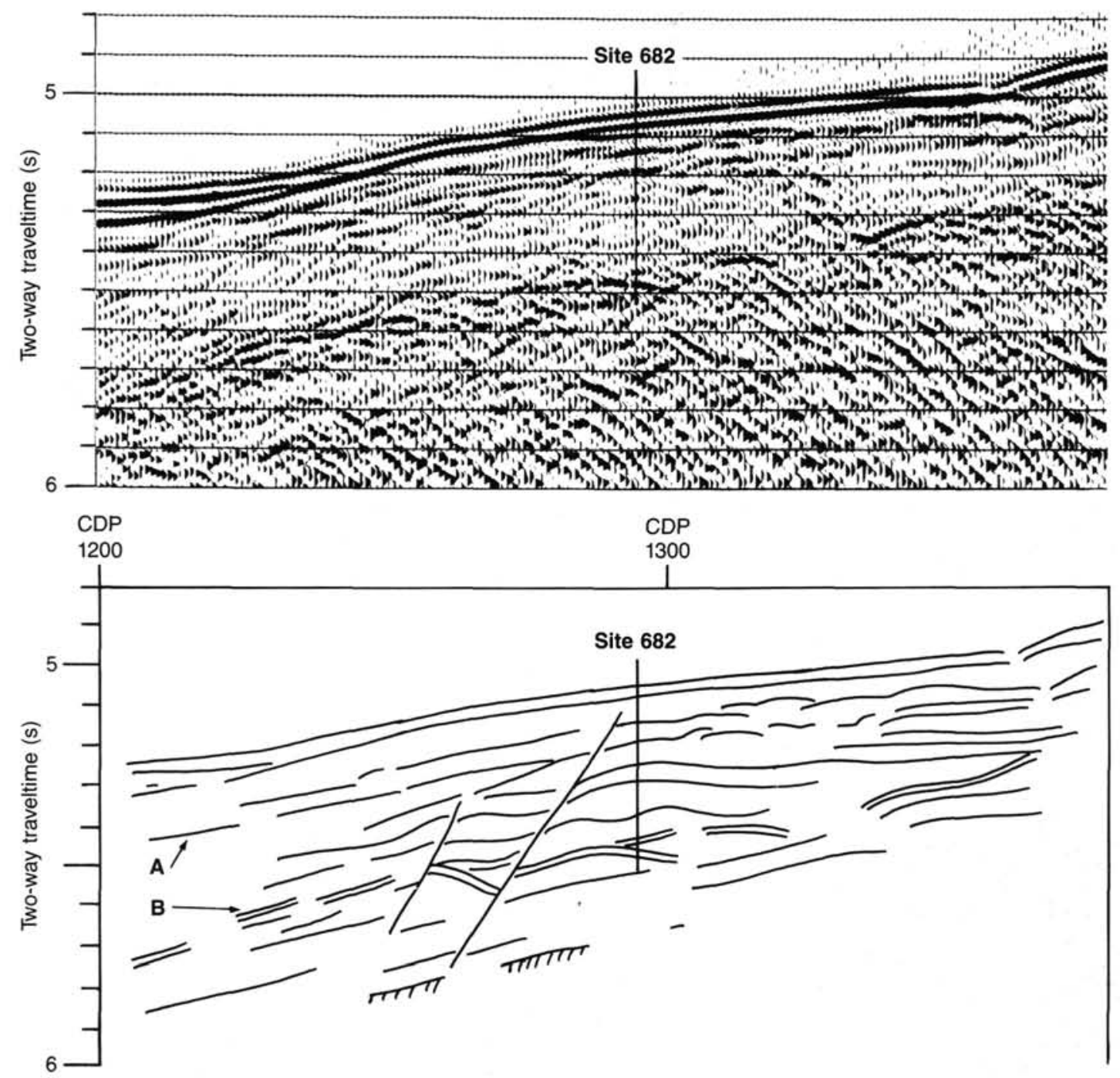

Figure 37. A part of multichannel seismic record 13 showing location of Site 682 (above), line drawing interpretation (below) indicates general structure. Reflection $\mathrm{A}$ is an unconformity below the near-surface reflections of high amplitude; $\mathrm{B}$ is a broken series of reflections of high amplitude penetrated by drilling at this site.

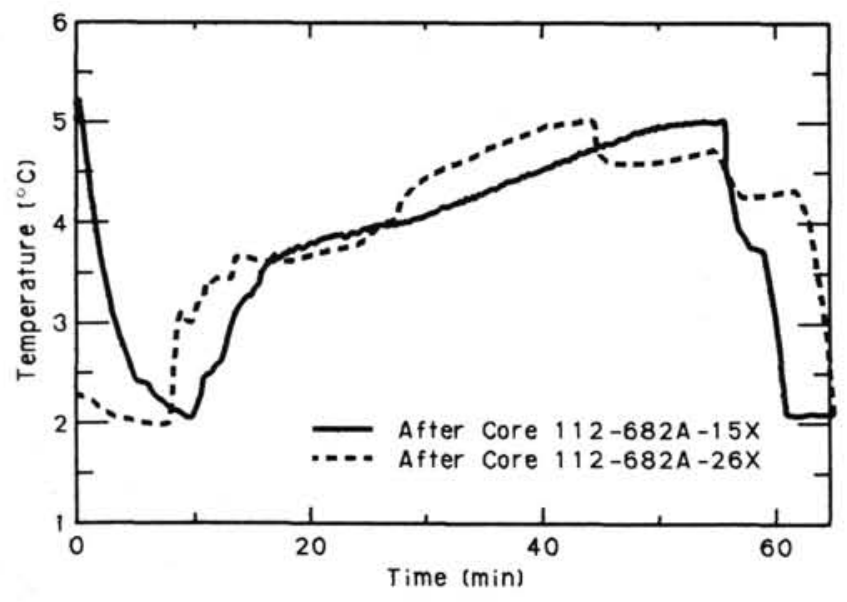

Figure 38. Temperature vs. time records with the APC tool, after Cores 112-682A-15X (solid line) and 112-682A-26X (broken line). suming that the velocity structure of the sediment layer is close to the generalized velocity/depth function for Leg 112 (see "Geophysics" section, Site 685 chapter, this volume), the estimated heat flow is about $50 \mathrm{~mW} / \mathrm{m}^{2}$. This is consistent with the surface measurement, although the possibility exists that this BSR does not represent the phase boundary (see "Organic Geochemistry" section, this chapter).

The surface measurement and the depth of the BSR indicate that the heat flow is much higher than the minimum heat flow obtained at Site 682 . Thus, the temperature measured with the APC tool attached to the pore-water sampler is probably far from the true formation temperature.

\section{SUMMARY AND CONCLUSIONS}

Tectonic studies resulting from the Nazca Plate Project indicated that the continental crust of Peru extended at least to the upper slope. This was indicated by observation of a continental velocity structure across most of the margin on seismic-refraction transects (Hussong et al., 1985) and by a reflection from the upper surface of crystalline crust near the shore that can be 


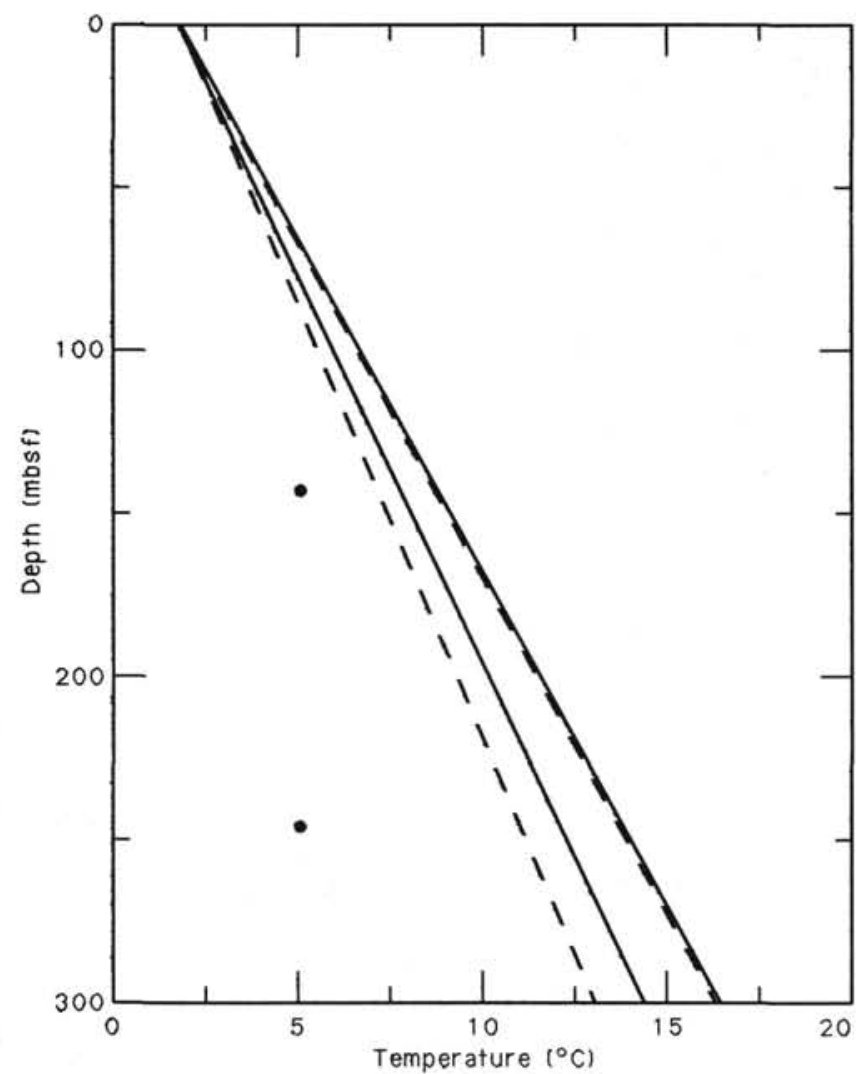

Figure 39. Temperature vs. depth plot for Hole 682A. Dots are the lower limit of the formation temperature determined by the APC tool. Solid lines show the temperature profiles estimated from the BSR, assuming that the sound velocity of sediment is 1.6 and $1.9 \mathrm{~km} / \mathrm{s}$. Broken lines show the profiles estimated from the surface heat-flow measurement assuming that the thermal conductivity of sediment is 1.0 and $1.3 \mathrm{~W} / \mathrm{m} \cdot \mathrm{K}$.

followed in multichannel seismic-reflection records to the lower slope (Hussong and Wipperman, 1981). Crystalline continental basement samples were recovered from the lower slope area by dredging (Kulm et al., 1986). The recovery of basement from a drill hole near the front of the margin could definitively have established the hypotheses of several authors. Although the basement was not penetrated at Site 682 , the overlying section displays continental affinities. Cores showed that the lower slope, by receiving terrigenous sediment since Eocene time, was probably part of the continental margin. Thus, the underlying crust was part of the Peruvian margin before the Andean orogeny, rather than an element accreted during that tectonic episode.

The lithostratigraphy and biostratigraphy of the $437 \mathrm{~m}$ penetrated at Site 682 is divided into three sequences that represent different tectonic environments. The first sequence represents the period of diatomaceous sedimentation that began in the middle Miocene and is recorded in the sediment from about 267 mbsf to the surface. The sediment sequence records a typical hemipelagic continental slope environment consisting of mud and biogenic components derived from the coastal upwelling regime upslope. The Quaternary and Pliocene sediments consist of poorly laminated diatomaceous mud mixed with terrigenous sand and interbeds of foraminifer- and nannofossil-bearing diatomaceous mud. Toward the bottom of the interval, the terrigenous components increase. These sediments contain all the diagenetic products associated with upwelling sediment that were noted in previous Leg 112 sites, except for phosphorites. The benthic-foraminifer assemblages lived at or near the present water depths; rare reworked microfossils were recovered. Paleonto- logical evidence indicates a relatively brief hiatus at the Miocene/Pliocene contact (114 mbsf) associated with a spectacular zone of slump folds and probably a change in the reflectivity of seismic horizons. The sediment consists of a finely laminated suboxic/anoxic facies associated with centers of coastal upwelling but not with transported material. The underlying upper Miocene diatomaceous mudstone becomes more consolidated and fractures readily. Micritic dolomite layers and authigenic calcite crystals appear in the upper Miocene. The benthic-foraminifer assemblages lived at middle, rather than lower, bathyal depths. Approximately $30 \mathrm{~m}$ below the hiatus, sediments are composed of materials eroded from upslope, as seen in the displacement of lower Miocene nannofossils, benthic foraminifers, and a mixed assemblage of diatoms. These transported components were noted through part of the upper and upper-middle Miocene to about 275 mbsf. A zone of poor recovery yielding only gravel marks an abrupt increase in consolidation of the sediment. The second sequence (320-387 mbsf) is a section of lower to middle Miocene mudstones that are texturally coarser, more terrigenous, and less diatomaceous than those above. Other general lithological differences include local volcanic ash and an apparent reduced rate of sedimentation partly due to compaction and tectonic effects. The very inhomogeneous lithologies indicate a varied environment on the continental slope. The recovered benthic-foraminifer assemblages have middle bathyal affinities, although a single lower bathyal assemblage with Oligocene-Miocene components was observed.

A major hiatus that probably includes most of the upper Eocene and lower Oligocene separates the second and third sediment sequences. Recovery across the hiatus was poor, and the rocks were badly brecciated. Rare clasts indicate proximity to continental basement, while the recovery of only gravel corresponds in character to the higher-than-background noise amplitude and broken reflections observed in seismic records. These reflections were followed at least $10 \mathrm{~km}$ across the dip of the slope and this extension, as well as the 15 m.y. time span represented in the missing rock, indicate an important unconformity. The middle and lower Eocene rocks below this hiatus are silty mudstones and sandstones locally cemented by authigenic carbonate. These rocks exhibit local blocky and pervasive scaly fractures as well as deformation in a semilithified state. Thus, in addition to deformation from downslope remobilization, there is also an imprint of deformation from deeper faults into shallow stratigraphic levels. Transported elements include Cretaceous nannofossils. The in-situ benthic-foraminifer assemblages lived at upper to upper-middle bathyal water depths.

These sediments showed most of the reaction pathways and products of early diagenetic processes, as previously seen in the upwelling sediments of the upper slope and shelf (Sites 679 through 681). They also indicated some characteristic differences. Carbonate mineral diagenesis was most prominent and included products from a sequence of reactions starting with sulfate reduction, calcite precipitation, pyritization, replacement by dolomite, and carbonate reduction by methanogens. Diagnostic changes in the interstitial-water and gas chemistries and the occurrence of micritic dolomite layers and authigenic calcite crystals, which appear in upper Miocene sediments, support the proposed reaction sequence. Phosphorites were conspicuously absent.

Diagenesis of sediments at Site 682 was not affected by the subsurface brine, as was the case at the upper-slope and shelf sites, nor was the mean rate of sedimentation at Site 682 as slow as that estimated for Sites 679 and 680 . These two factors led to rapid exhaustion of interstitial sulfate at Site 682 so that methanogenesis dominated the diagenetic environment on the lower slope. We expected that the diagenetic dolomite lithologies found here would record this characteristic environment in their stable carbon isotope composition. Formation of gas hydrates was an- 
other consequence of the high biogenic methane contents generated here. Characteristic dissolved chloride profiles in interstitial waters signal the presence of methane hydrates, although none were observed visually. A small but significant chloride maximum around $50 \mathrm{mbsf}$ is the first evidence ever recorded for the salt exclusion during the formation of gas hydrates. This maximum appears to advance above the gas hydrate front by diffusion. A gradual overall chloride decrease below was attributed to fresh-water dilution from dissociation of gas hydrates.

The hydrocarbon gases showed an overall decrease in the methane/ethane ratio in a manner normal for deep-sea sediments; however, we encountered three isolated, abrupt decreases in the ratio. We concluded that below some threshold drilling rate, heat from friction at the drill bit thermally alters the sediment organic matter and thereby artificially produces higher order hydrocarbons, one of which (ethene) is not normally present in a natural environment. Rock-Eval results indicated immature, organic-rich materials derived mainly from marine sources.

The abundance of diatoms in the upper $150 \mathrm{~m}$ of sediment was reflected in the physical-properties measurements. The cyclic signal noted in Quaternary sediments from sites on the shelf was also noted in plots of index properties that are a function of the water content. The intensity of magnetism showed a similar cyclicity. Below the zone of abundant diatomaceous material, the consolidation characteristics of the sediment became more like those of oceanic sediments.

Shipboard studies of sediments from Site 682 indicated a fundamental trend from coarse clastic material at the bottom of the hole to fine material of a distal character at the top. When related to the regional geology, a tectonic history spanning uplift of the present Andean mountain range was revealed. The Eocene rocks reflect an upper-slope environment where materials from the adjacent shelf and hemipelagic muds were deposited. This was followed by erosion and perhaps nondeposition during a $15-\mathrm{m} . \mathrm{y}$. period and by subsidence to middle bathyal depth. The pronounced late Eocene lowering of sea levels and the beginning of volcanism in the Cordillera Occidental occurred in the period from 42 to $30 \mathrm{Ma}$, for which sediments are missing at Site 682. A better linkage of these events might possibly have been made with better core recovery. The lower and lower-middle Miocene sediments indicate a more distal environment than the Eocene ones, with a change in clastic sediment sources and more biogenic material deposited in the Miocene. The local carbonate-rich intervals of the earlier period gave way to silica-rich diatomaceous intervals in the later period, perhaps recording the incipient stage of the present upwelling conditions. Occurring at the same time as the diatomaceous sediments was the first northward incursion of Antarctic bottom waters. By the upper-middle Miocene, the sediments were flooded with diatoms and other products from coastal upwelling upslope. These sediments also contained the material eroded from the midslope area, which is missing from the upper-slope stratigraphy observed at Site 679. The reprocessed seismic data clearly image not only the profound erosion from which the transported material was derived, but also the uneroded remnants of the section farther down the slope. Erosion ended in the latest Miocene, leading to a Pliocene and Quaternary period in which the present depositional environments developed.

\section{REFERENCES}

Barron, J., 1985. Late Eocene to Holocene diatom biostratigraphy of the equatorial Pacific Ocean, Deep Sea Drilling Project Leg 85. In Mayer, L., Theyer, F., Thomas, E., et al., Init. Repts. DSDP, 85: Washington (U.S. Govt. Printing Office), 413-456.

Bé, A.W.H., 1977. An ecological, zoogeographic and taxonomic review of Recent planktonic foraminifera. In Ramsay, A.T.S (Ed.), Oceanic Micropaleontol. 1:1-100.
Becker, L., and Dusenbury, A., 1958. Mio-Oligocene (Aquitanian) foraminifera from the Goajira Peninsula, Colombia. Cushman Found. Foram. Res. Spec. Publ., 4:1-48.

Berggren, W. A., 1977a. Late Neogene planktonic foraminiferal biostratigraphy of Site 357 (Rio Grande Rise). In Supko, P. R., Perch-Nielsen, K., et al., Init. Repts. DSDP, 39: Washington (U.S. Govt.Printing Office), 591-614.

1977b. Atlas of Palaeogene planktonic foraminifera. Some species of the genera, Subbotina, Planorotalites, Morozovella, Acarinina and Truncorotaloides. In Ramsay, A.T.S. (Ed.), Oceanic Micropaleontol., 1:205-300.

Blow, W. H., 1969. Late middle Eocene to Recent planktonic foraminiferal biostratigraphy. In Bronnimann, P., and Renz, H. H. (Eds.), Proc. First Intl. Conf. Plank. Microfossil, 1:199-421.

Claypool, G. E., and Kvenvolden, K. A., 1983. Methane and other hydrocarbon gases in marine sediment. Annu. Rev. Earth Planet. Sci. 1983, 11:299-327.

Cruzado, J., 1985. Foraminiferos planktonicos del Noroeste Peruano. Bolet. Soc. Geolog. Peru, 74:1-15.

Cushman, J., and Stone, B., 1947. An Eocene foraminiferal fauna from the Chira Shale of Peru. Cushman Lab. Foram. Res., Spec. Publ., 20:1-27.

Gieskes, J. M., Elderfield, H., Lawrence, J. R., Johnson, J., Meyers, B., and Campbell, A., 1982. Geochemistry of interstitial waters and sediments, Leg 64, Gulf of California. In Curray, J. R., Moore, D. G., et al., Init. Repts. DSDP, 64: Washington (U.S. Govt. Printing Office), 675-694.

Harrison, W. E., Hesse, R., and Gieskes, J. M., 1982. Relationship between sedimentary facies and interstitial water chemistry of slope, trench, and Cocos plate sites from the Middle America Trench transect, active margins off Guatemala, Deep Sea Drilling Project Leg 67. In Aubouin, J., von Huene, R., et al., Init. Repts. DSDP, 67: Washington (U.S. Govt. Printing Office), 603-613.

Haq, B. U., Hardenbol, J., and Vail, P. R., 1987. Chronology of fluctuating sea levels since the Triassic ( 250 million years ago to present). Science, 235:1150-1167.

Hesse, R., Lebel, J., and Gieskes, J. M., 1985. Interstitial water chemistry of gas-hydrate-bearing sections on the Middle America Trench slope, Deep Sea Drilling Project, Leg 84. In von Huene, R., Aubouin, J., et al., Init. Repts. DSDP, 84: Washington (U.S. Govt. Printing Office), 727-737.

Hsü, K. J., et al., 1977. History of the Mediterranean salinity crisis. $\mathrm{Na}$ ture, 267:399-403.

Hussong, D. M., and Wipperman, C. K., 1981. Vertical movement and tectonic erosion of the continental wall of the Peru-Chile Trench near $11^{\circ} 30^{\prime}$ S latitude. In Kulm, L, D., Dymond, J., Dasch, E. J., and Hussong, D. M. (Eds.), Nazca Plate: Crustal Formation and Adean Convergence. Geol. Soc. Am. Mem., 154:509-524.

Hussong, D. M., Dang, S. P., Kulm, L. D., Couch, R. W., and Hilde, T.W.C. (Eds.), 1985. Atlas of the Ocean Margin Drilling Program, Regional Atlas Series, Atlas 9: Woods Hole (Marine Science International).

Ingle, J., 1980. Cenozoic paleobathymetry and depositional history of selected sequences within the Southern California Continental Borderland. Cushman Found. Foram. Res., Spec. Publ. 19:163-195.

Jones, P. R., 1981. Crustal structure of the Peru continental margin and adjacent Nazca Plate, $9^{\circ} \mathrm{S}$ latitude. In Kulm, L. D., Dymond, J., Dasch, E. J., and Hussong, D. M. (Eds.), Nazca Plate: Crustal Formation and Andean Convergence. Geol. Soc. Am. Mem., 154:423443.

Keller, G., and Barron, J. A., 1983. Paleoceanographic implications of Miocene deep-sea hiatuses. Geol. Soc. Am. Bull., 94:590-613.

Kleinpell, R., 1938. Miocene Stratigraphy of California. AAPG Publ., $1-450$.

Kling, S. A., 1978. Radiolaria. In Haq, B. H., and Boersma, A. (Eds.), Introduction to Marine Micropaleontology: New York, Amsterdam, Oxford (Elsevier Publishing Co.), 203-244.

Kulm, L. D., Thornburg, T., and Resig, J., in press. Final report of conduct of the Peru-Chile site survey.

Kulm, L. D., Schrader, H., Resig, J. M., Thornburg, T. M., Masias, A., and Johnson, L., 1981. Late Cenozoic carbonates on the Peru continental margin: lithostratigraphy, biostratigraphy, and tectonic history. In Kulm, L. D., Dymond, J., Dasch, E. J., and Hussong, D. 
M. (Eds.), Nazca Plate: Crustal Formation and Andean Convergence. Geol. Soc. Am. Mem., 154:469-508.

Kvenvolden, K. A., 1985. Comparison of marine gas hydrates in sediments of an active and passive margin. Mar. Petrol. Geol., 2:65-71.

Kvenvolden, K. A., and Barnard, L. A., 1983. Gas hydrates of the Blake Outer Ridge, Site 533, Deep Sea Drilling Project Leg 76. In Sheridan, R. E., Gradstein, F. M., et al., Init. Repts. DSDP, 76: Washington (U.S. Govt. Printing Office), 353-365.

Kvenvolden, K. A., and McDonald, T. J., 1985. Gas hydrates of the Middle America Trench-Deep Sea Drilling Project Leg 84. In von Huene, R., Aubouin, J., et al., Init. Repts. DSDP, 84: Washington (U.S. Govt. Printing Office), 667-682.

1986. Organic geochemistry on the JOIDES Resolution-an assay. Ocean Drilling Program Technical Note 6.

Kvenvolden, K. A., and McMenamin, M. A., 1980. Hydrates of natural gas: a review of their geologic occurrence. U.S. Geol. Surv. Cir. 825.

Leggett, J. K., 1982. Drilling induced structures in Leg 66 cores. In Watkins, J. S., Moore, J. C., et al., Init. Repts. DSDP, 66: Washington (U.S. Govt. Printing Office), 531-538.

Locker, S., and Martini, E., 1986. Silicoflagellates and some sponge spicules from the southwest Pacific, Deep Sea Drilling Project, Leg 90. In Kennett, J. P., von der Borch, C. C., et al., Init. Repts. DSDP, 90: Washington (U.S. Govt. Printing Office), 887-924.

Martini, E., 1971. Neogene silicoflagellates from the equatorial Pacific. In Winterer, E. L., Riedel, W. R., et al., Init. Repts. DSDP, 7 (Pt.2): Washington (U.S. Govt. Printing Office), 1695-1708.

Martini, E., 1976. Neogene and Quaternary silicoflagellates from the central Pacific Ocean (DSDP Leg 33). In Schlanger, S. O., Jackson, E. D., et al., Init. Repts. DSDP, 33: Washington (U.S. Govt. Printing Office), 439-449.

Moore, G. W., and Gieskes, J. M., 1980. Interaction between sediment and interstitial water near the Japan Trench, Leg 57, Deep Sea Drilling Project. In Scientific Party, Init. Repts. DSDP, 56, 57 (Pt. 2): Washington (U.S. Govt. Printing Office), 1269-1275.

Nigrini, C., 1977. Tropical Cenozoic Artostrobiidae (Radiolaria). Micropaleontology, 23(3):241-269.

Odin, G. S., and Matter, A., 1981. De glauconiarium origine. Sedimentology, 28:611-641.

Poore, R. Z., 1979. Oligocene through Quaternary planktonic foraminiferal biostratigraphy of the North Atlantic: DSDP Leg 49. In Luy- endyk, B. P., Cann, J. R., et al., Init. Repts. DSDP, 49: Washington (U.S. Govt. Printing Office), 447-517.

Renz, H., 1948. Stratigraphy and fauna of the Agua Salada Group, State of Falcon, Venezuela. Geol. Soc. Am. Mem., 32:1-219.

Rice, D. D., and Claypool, G. E., 1981. Generation, accumulation, and resource potential of biogenic gas. AAPG Bull., 65:5-25.

Riedel, W. R., and Sanfilippo, A., 1978. Stratigraphy and evolution of tropical Cenozoic radiolarians. Micropaleontology, 24:61-96.

Shackleton, N. J., and Kennett, J. P., 1975. Paleotemperature history of the Cenozoic and the initiation of Antarctic glaciation: oxygen and carbon isotope analysis in DSDP Sites 277,279 , and 281 . In Kennett, J. P., Houtz, R. E., et al., Init. Repts. DSDP., 29: Washington (U.S. Govt. Printing Office), 743-755.

Shipley, T. H., Houston, M. H., Buffler, R. T., Shaub, F. J., McMillan, K. J., Ladd, J. W., and Worzel, J. L., 1979. Seismic evidence for widespread possible gas hydrate horizons on continental slopes and rises. AAPG Bull., 63:2204-2213.

Stainforth, R. M., et al. 1975. Cenozoic planktonic foraminiferal zonation and characteristics of index forms, Appendix. Univ. Kansas Paleontol. Contr., 62:163-425.

Suess, E., Kulm, L. D., and Killingley, J. S., 1987. Coastal upwelling and a history of organic-rich mudstone deposition off Peru. In Brooks, J., and Fleet, A. J. (Eds.), Marine Petroleum Source Rocks. Geol. Soc. Am. Spec. Publ., 24:181-197.

Tissot, B. P., and Welte, D. H., 1984. Petroleum Formation and Occurrence (2nd Ed.): Berlin-Heidelberg (Springer-Verlag).

von Huene, R., Kulm, L. C., and Miller, J., 1985. Structure of the frontal part of the Andean convergent margin. J. Geophys. Res., 90(B7): 5429-5442.

Woodruff, F., Savin, S. M., Douglas, R. G., 1981. Miocene stable isotope record: a detailed deep Pacific Ocean study and its paleoclimatic implications. Science, 212:665-668.

Yamano, M., 1986. Heat flow studies of the circum-Pacific subduction zones [D.Sc. dissert.]. Tokyo (University of Tokyo).

Yamano, M., Uyeda, S., Aoki, Y., and Shipley, T. H., 1982. Estimates of heat flow derived from gas hydrates. Geology, 10:339-343.

\section{Ms 112A-113}



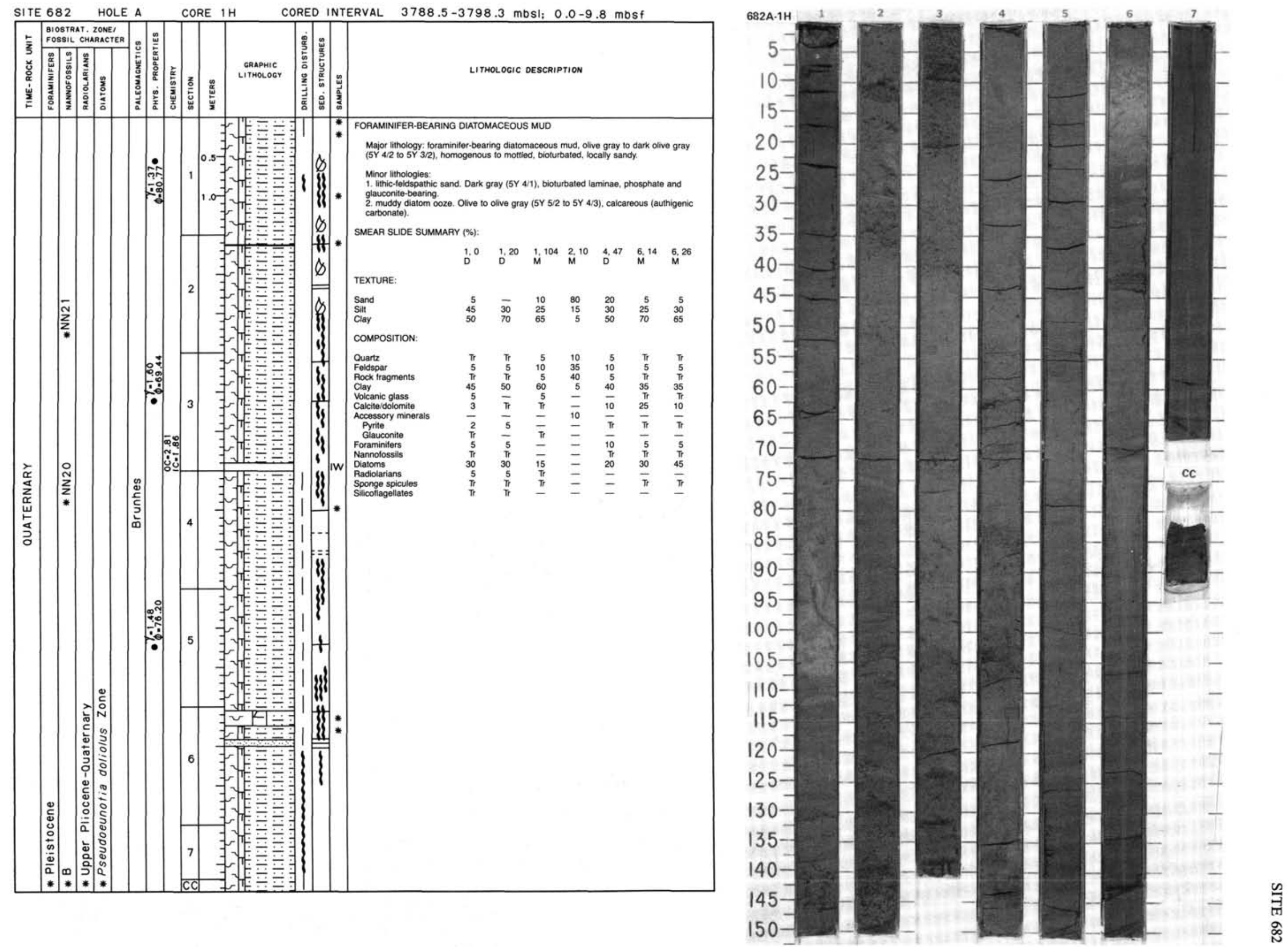

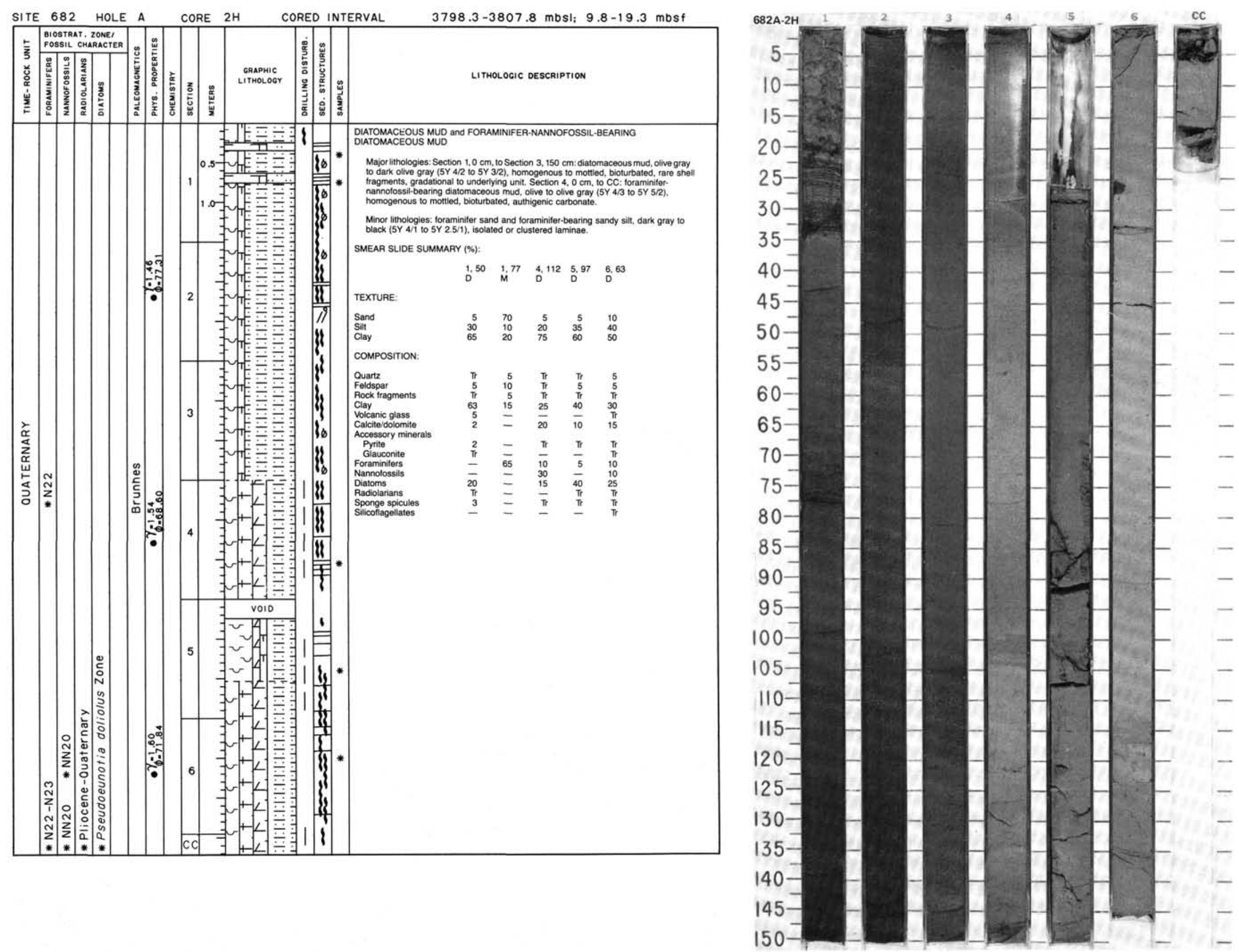


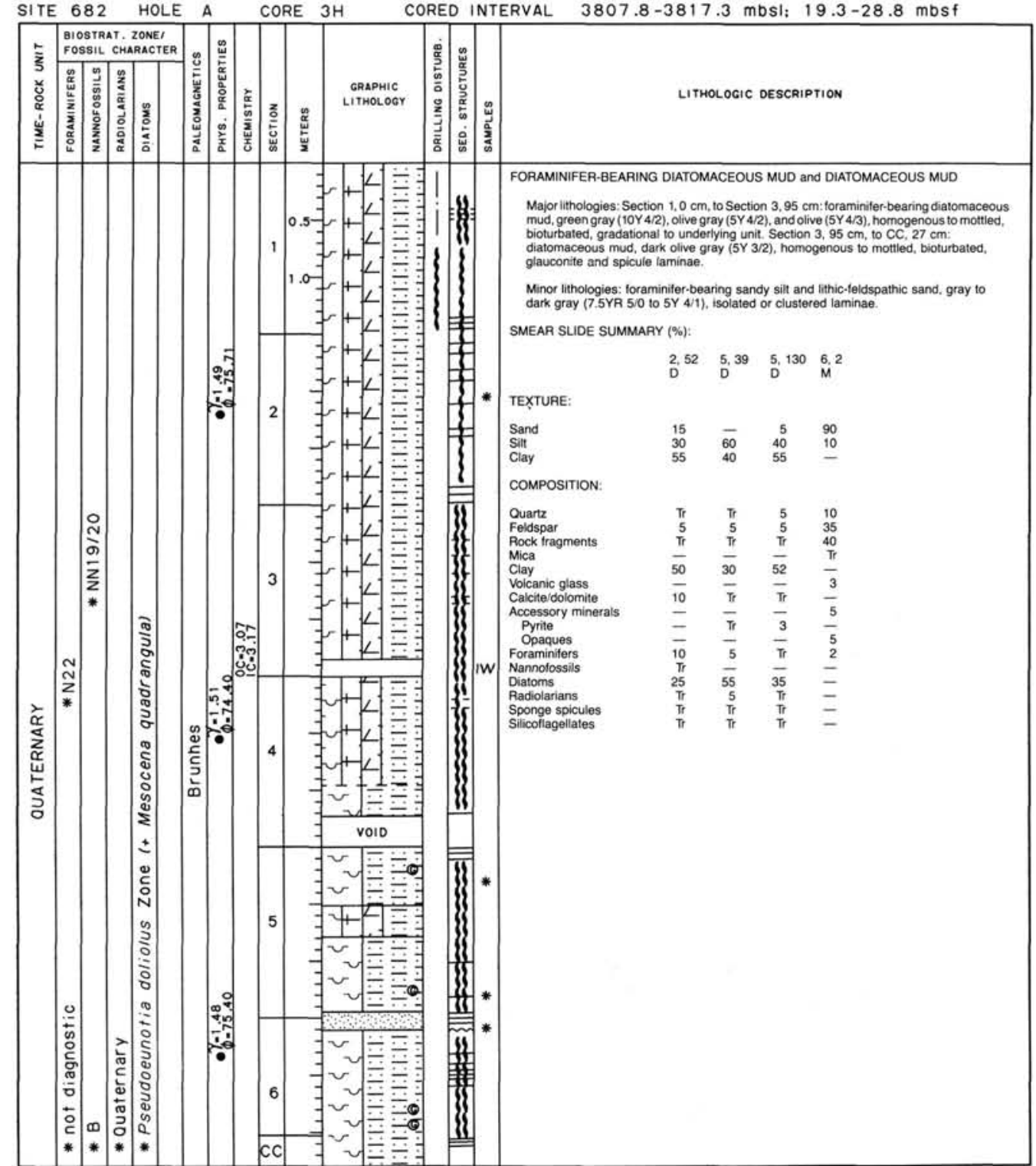

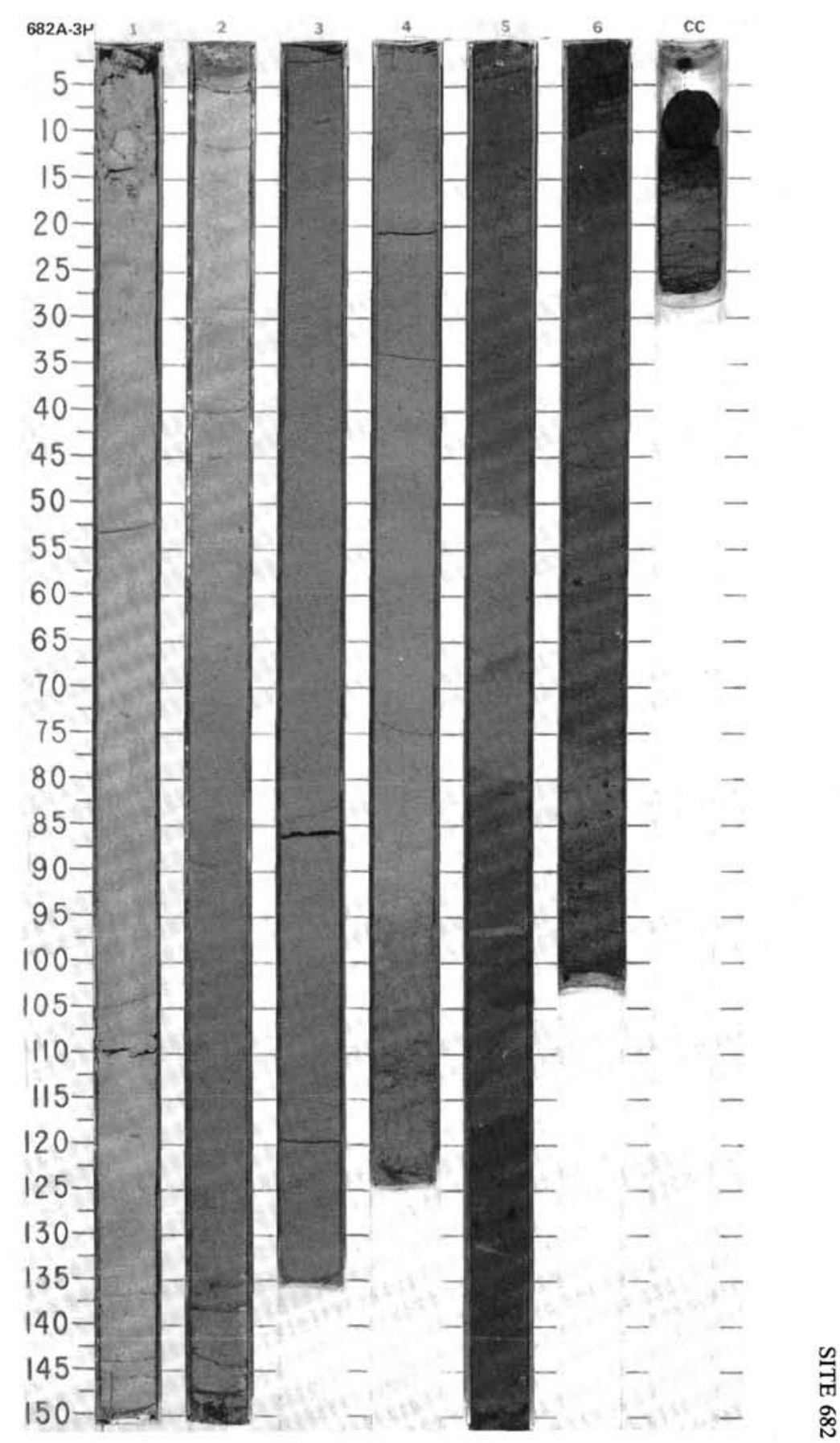



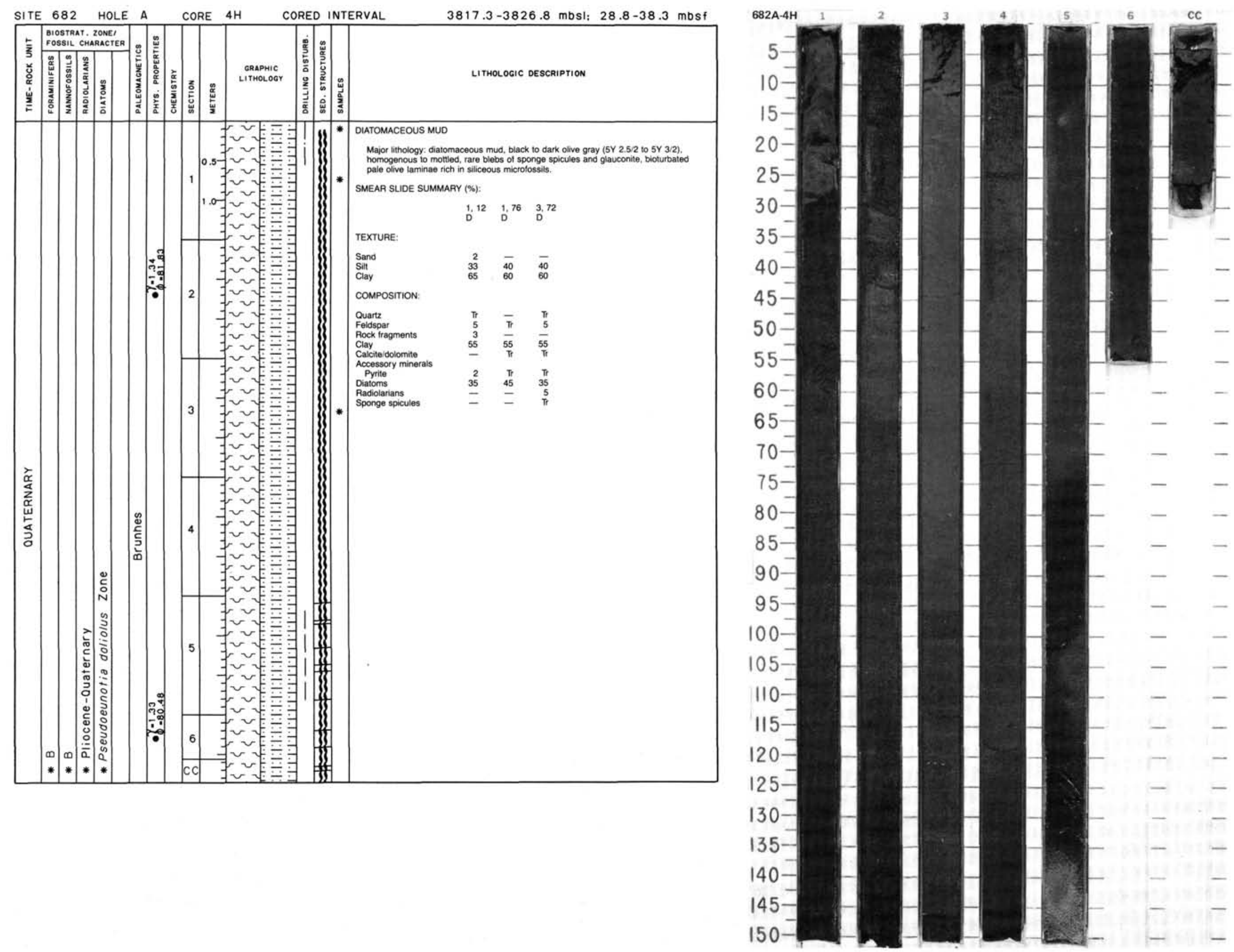


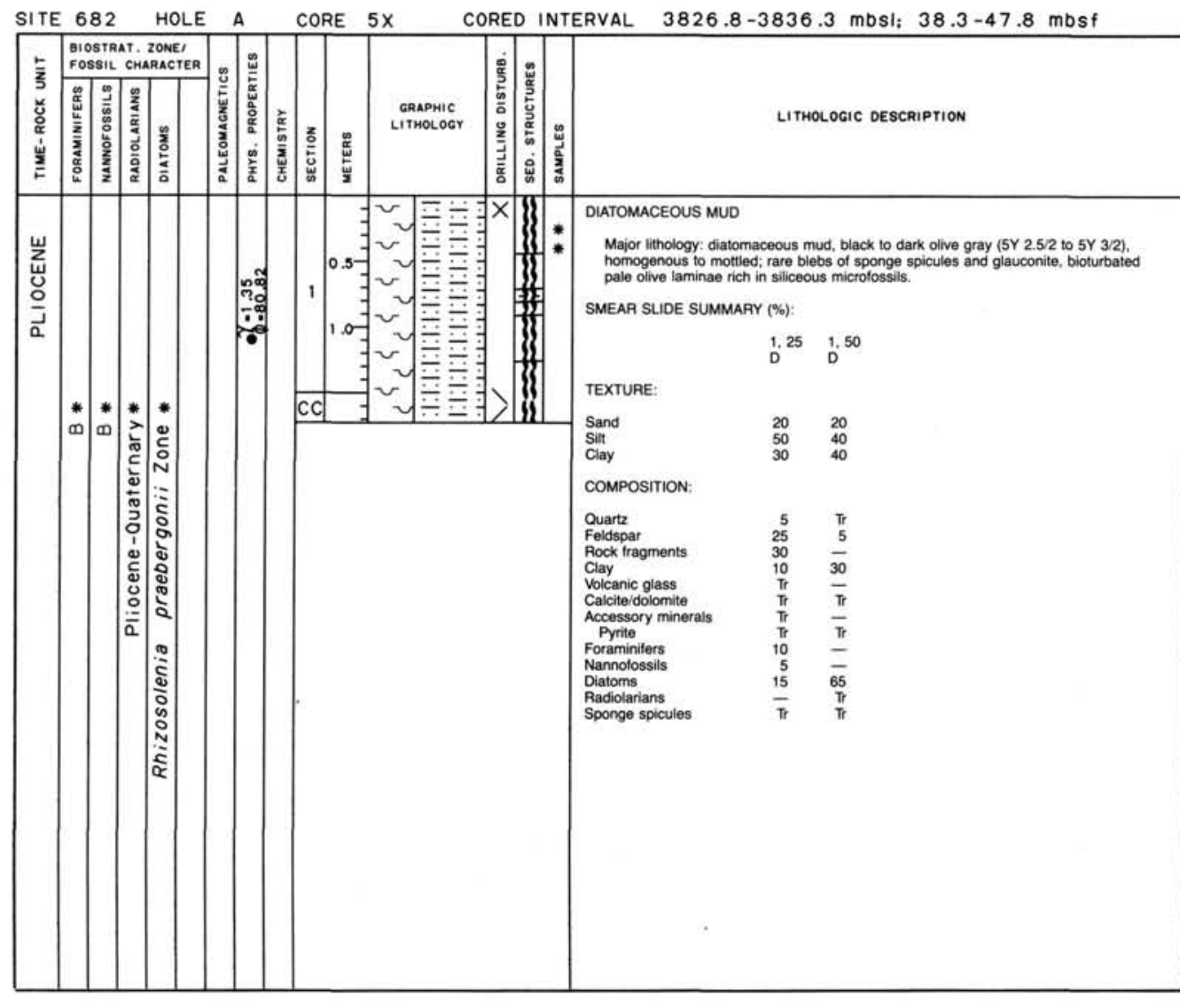

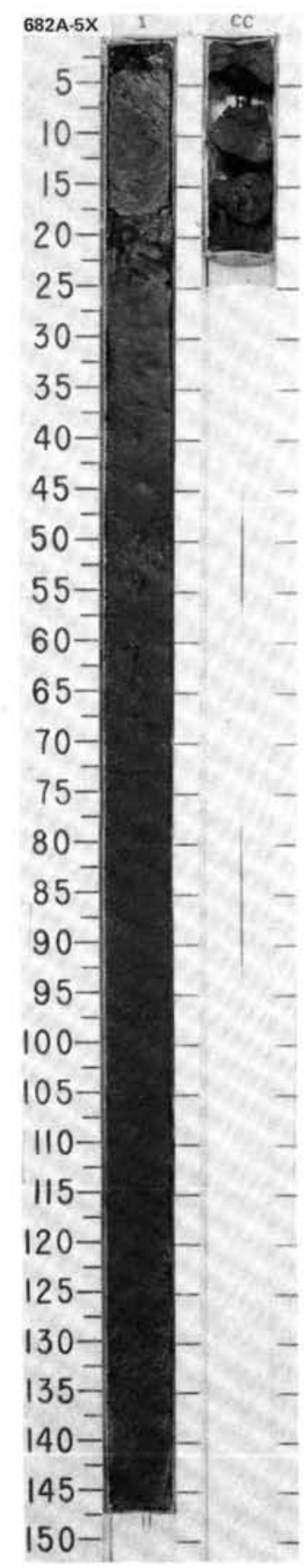



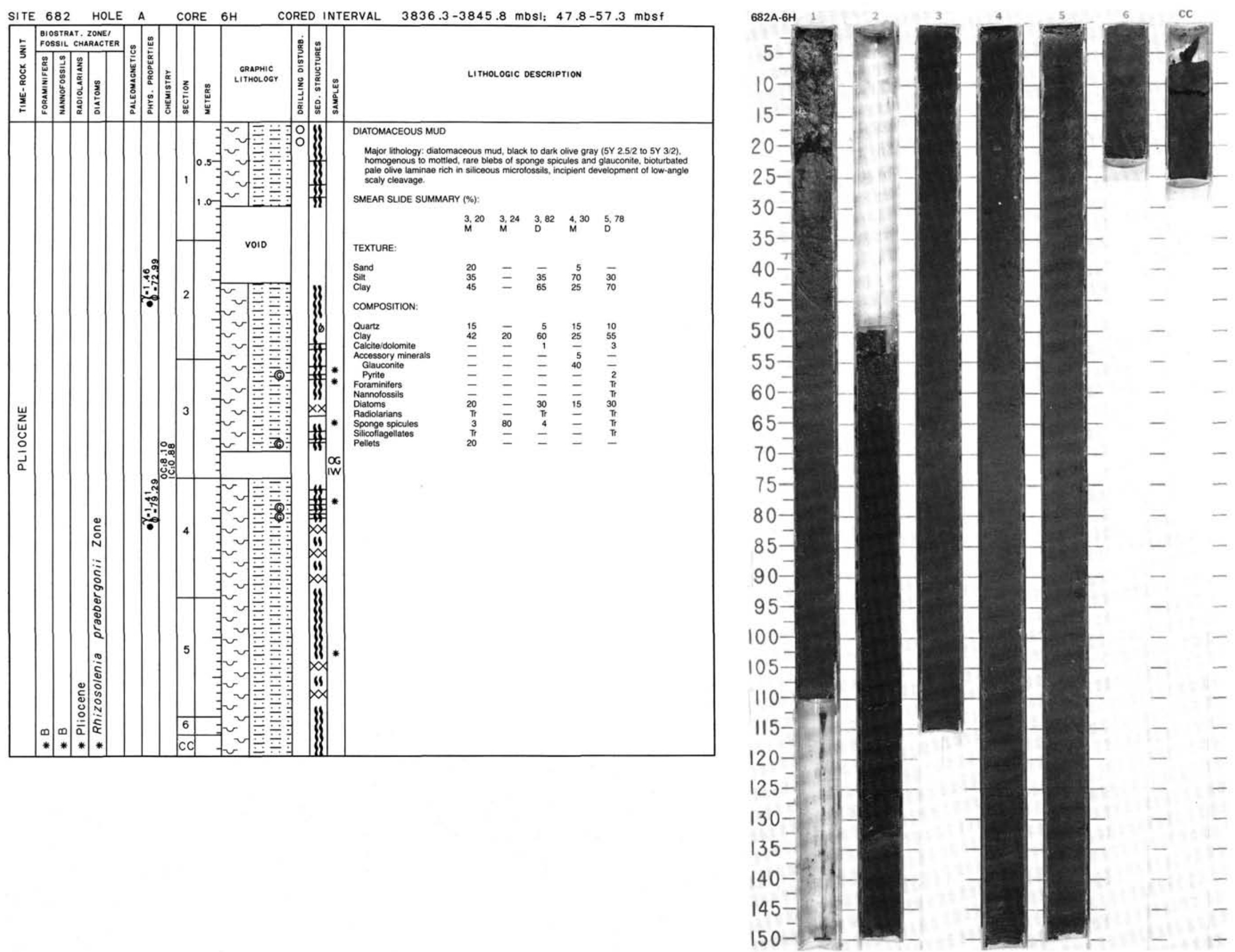

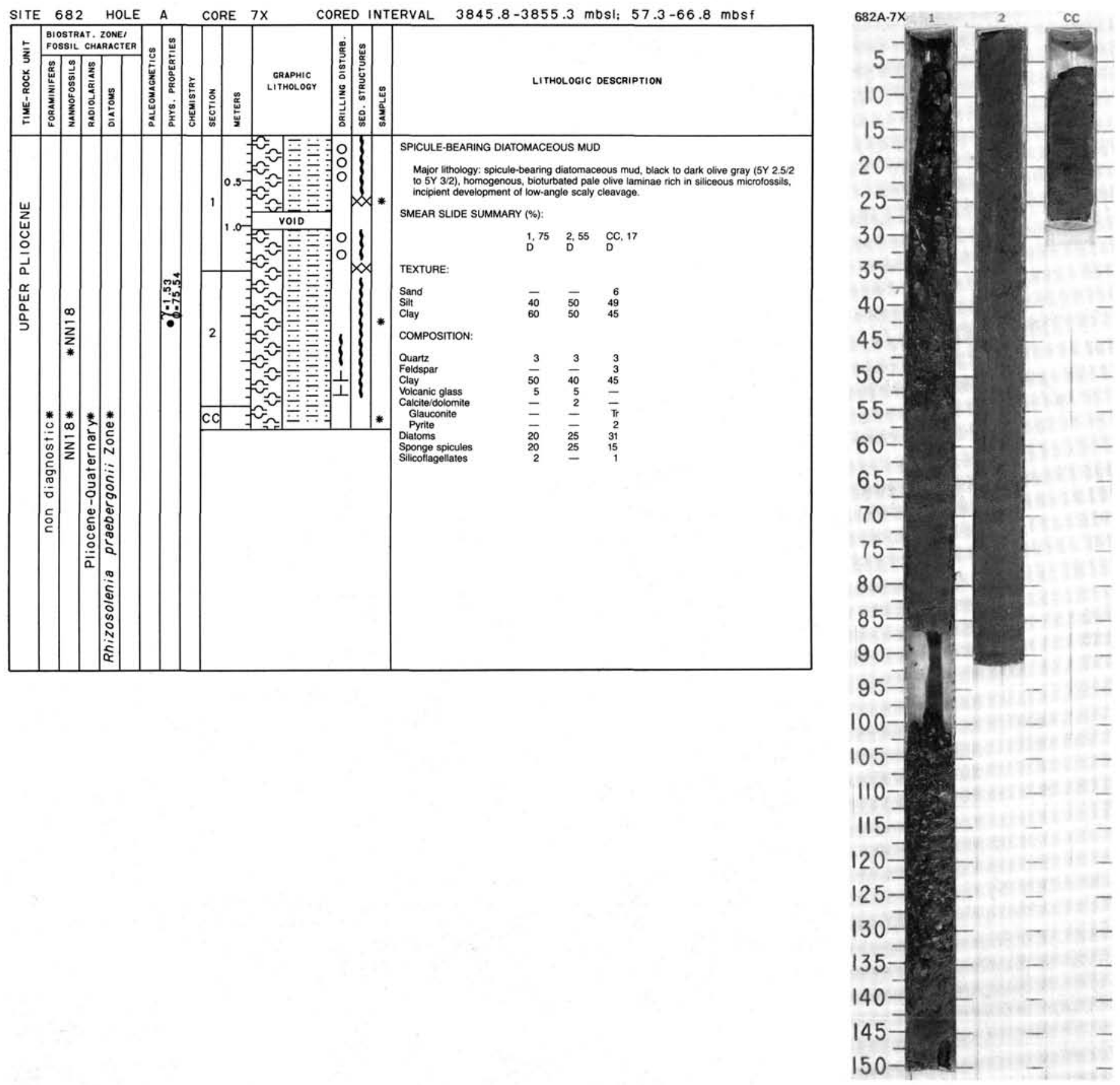

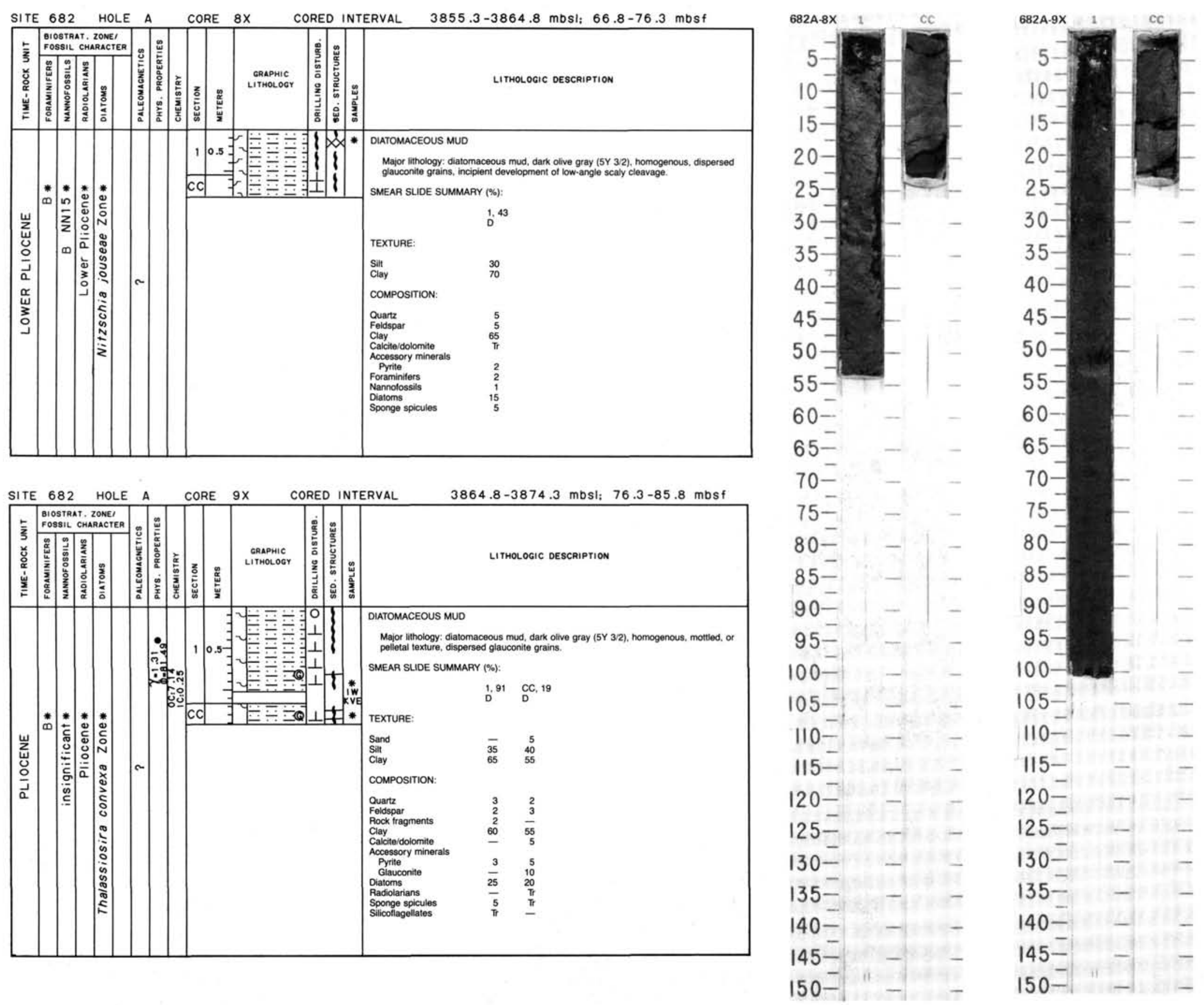

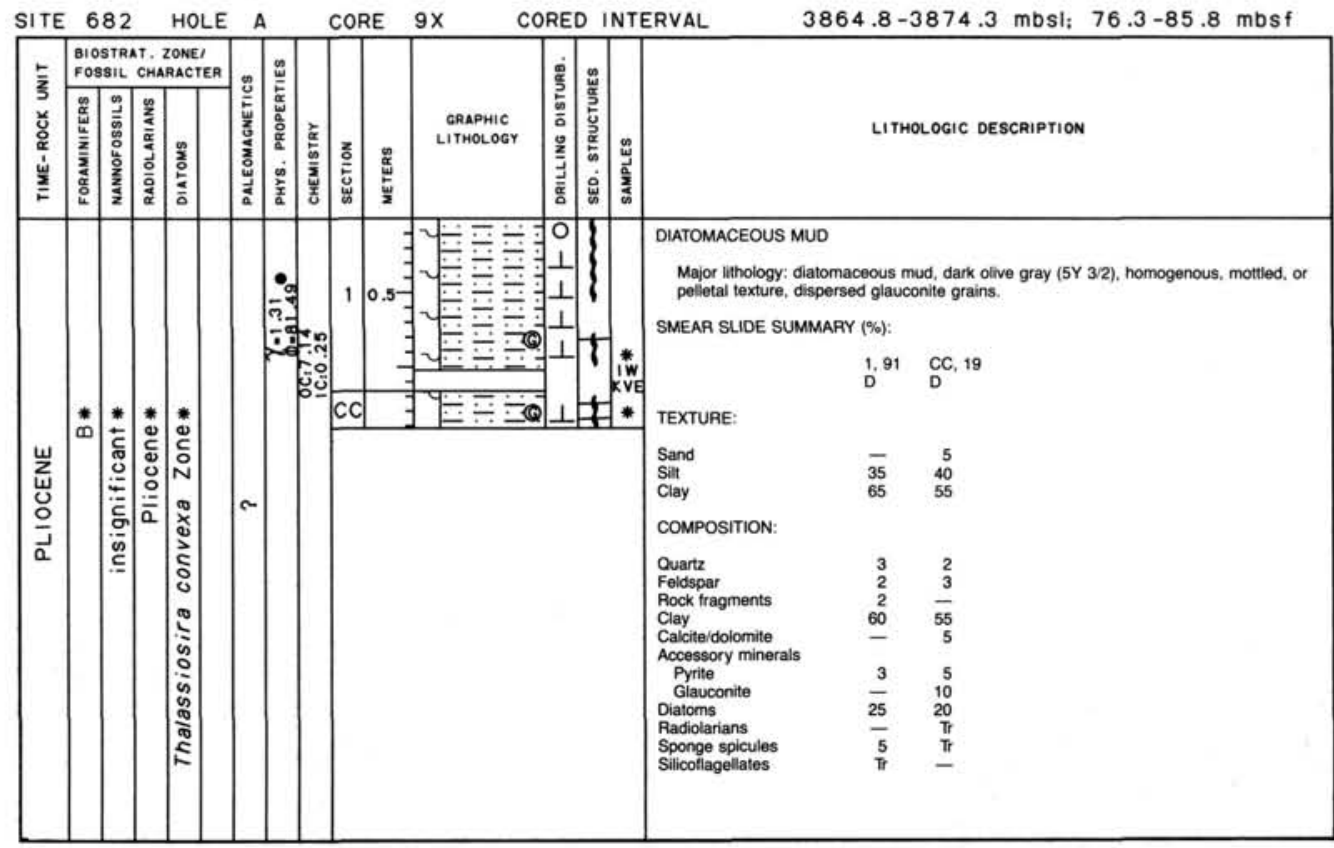



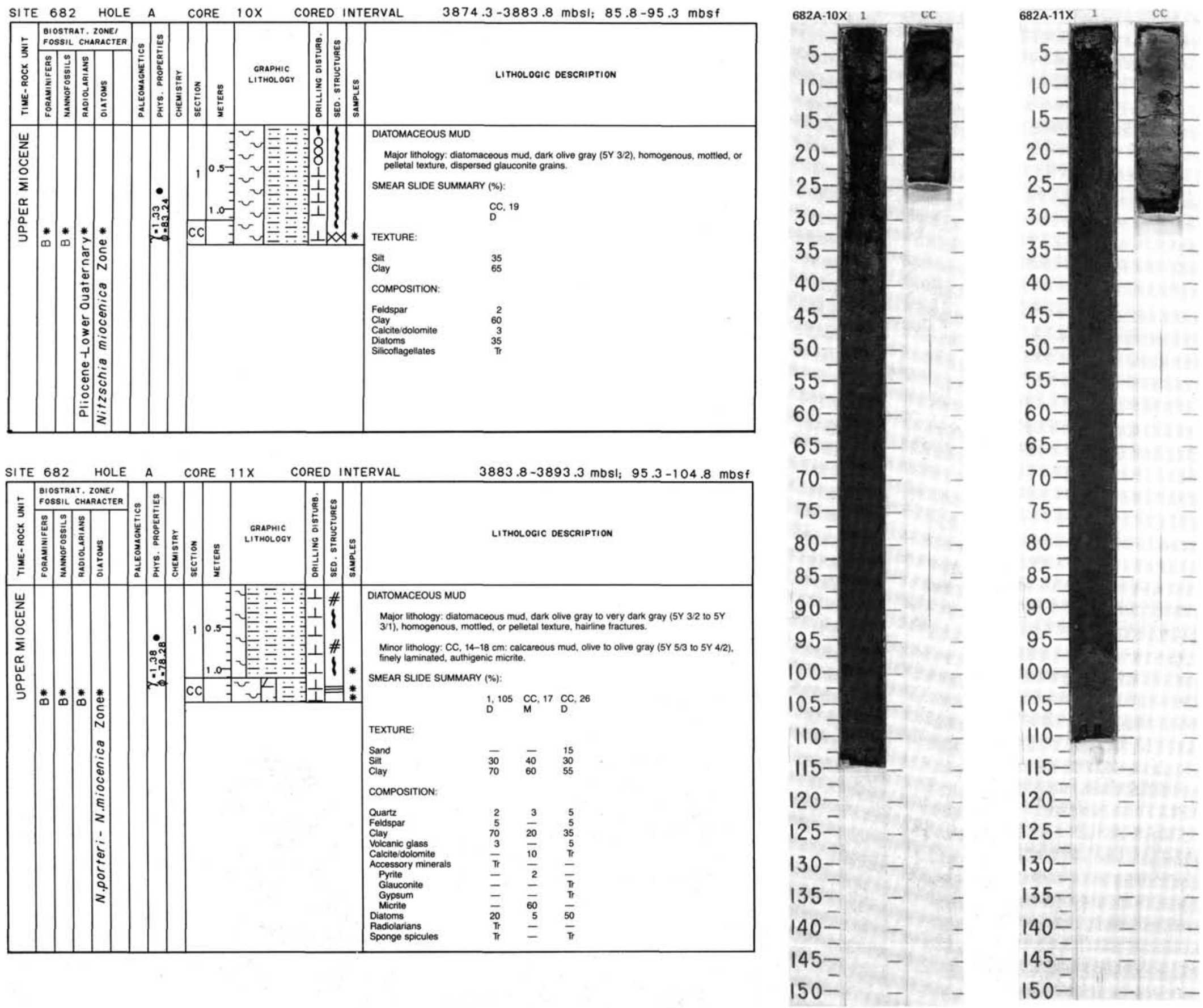

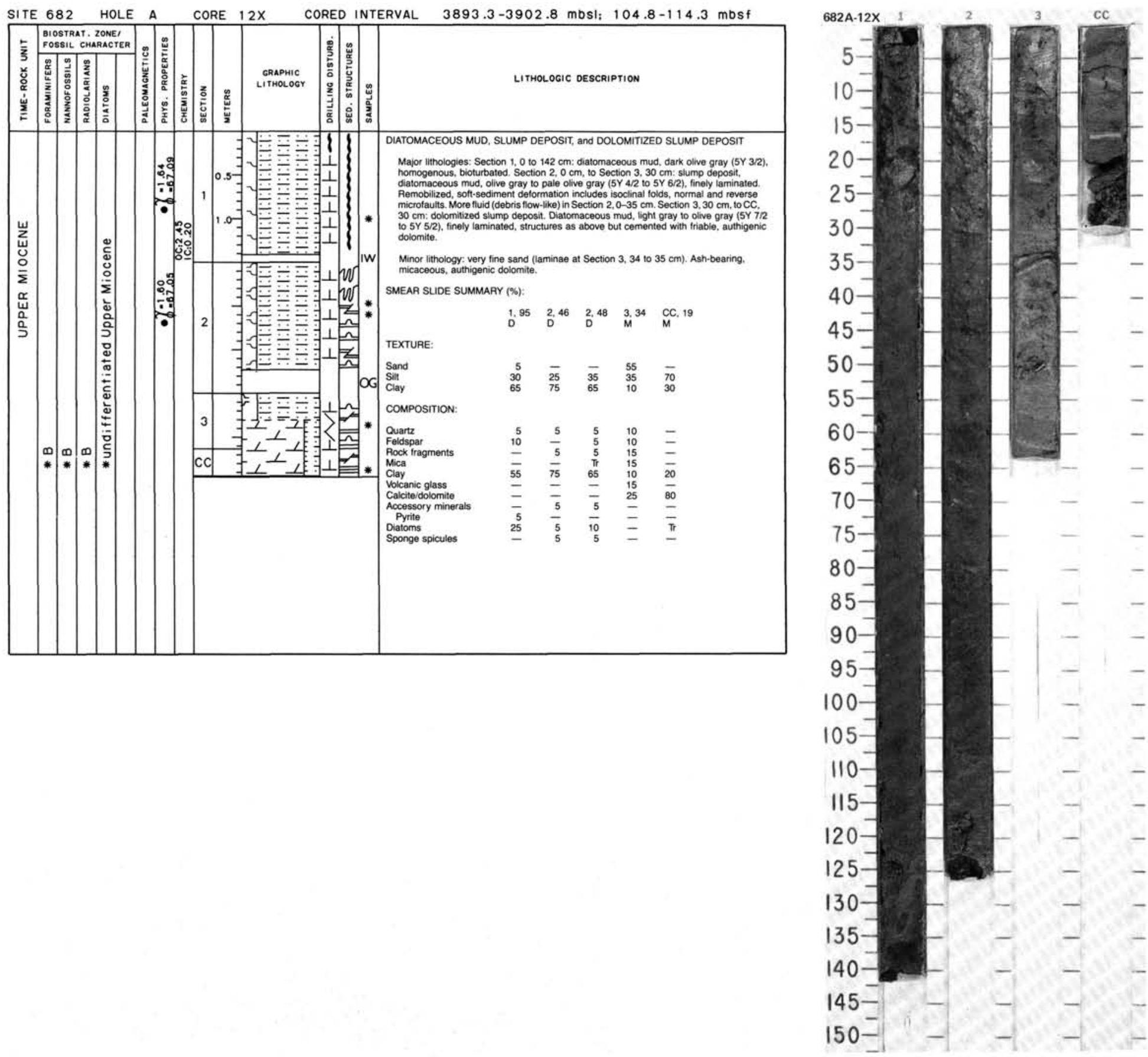


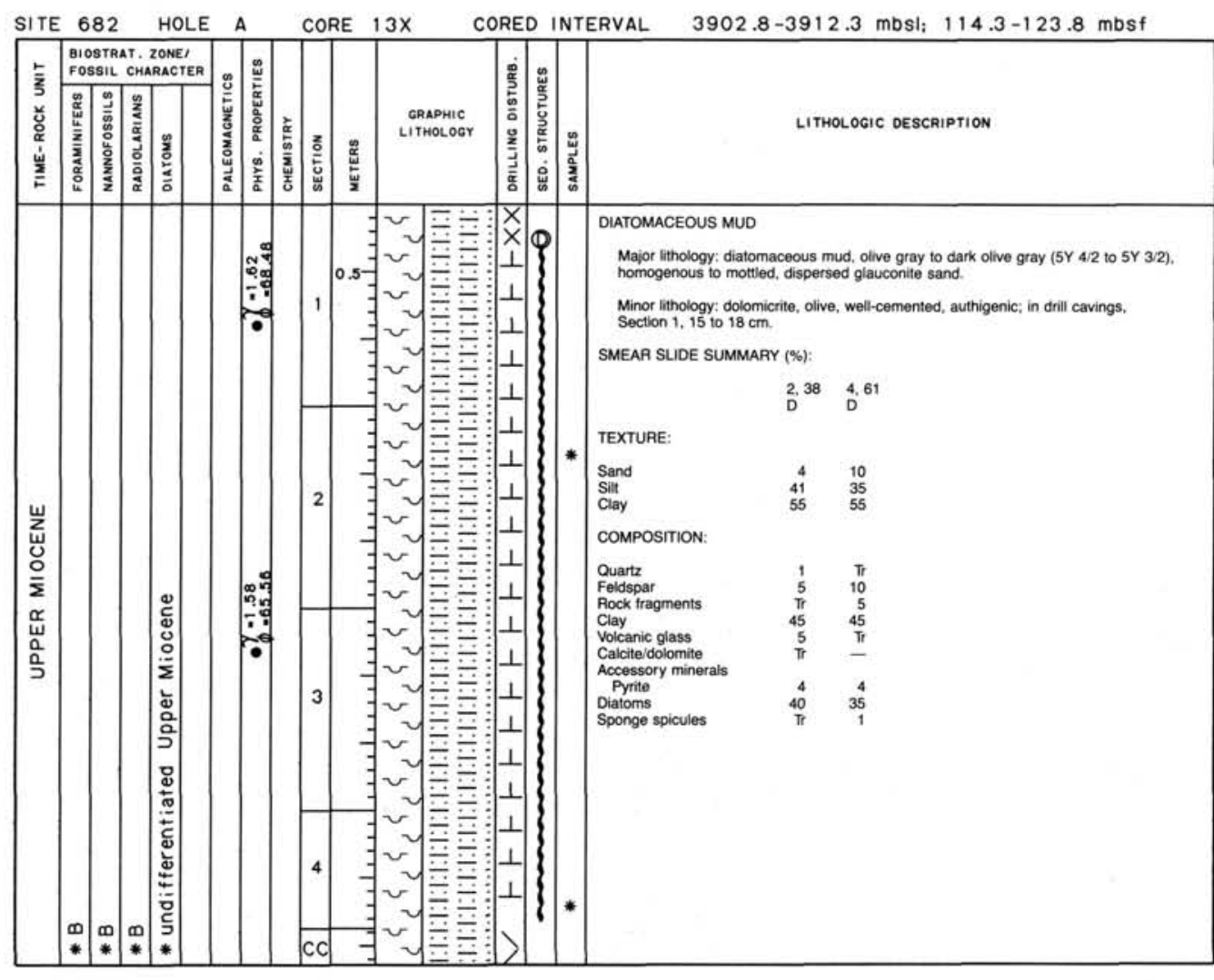

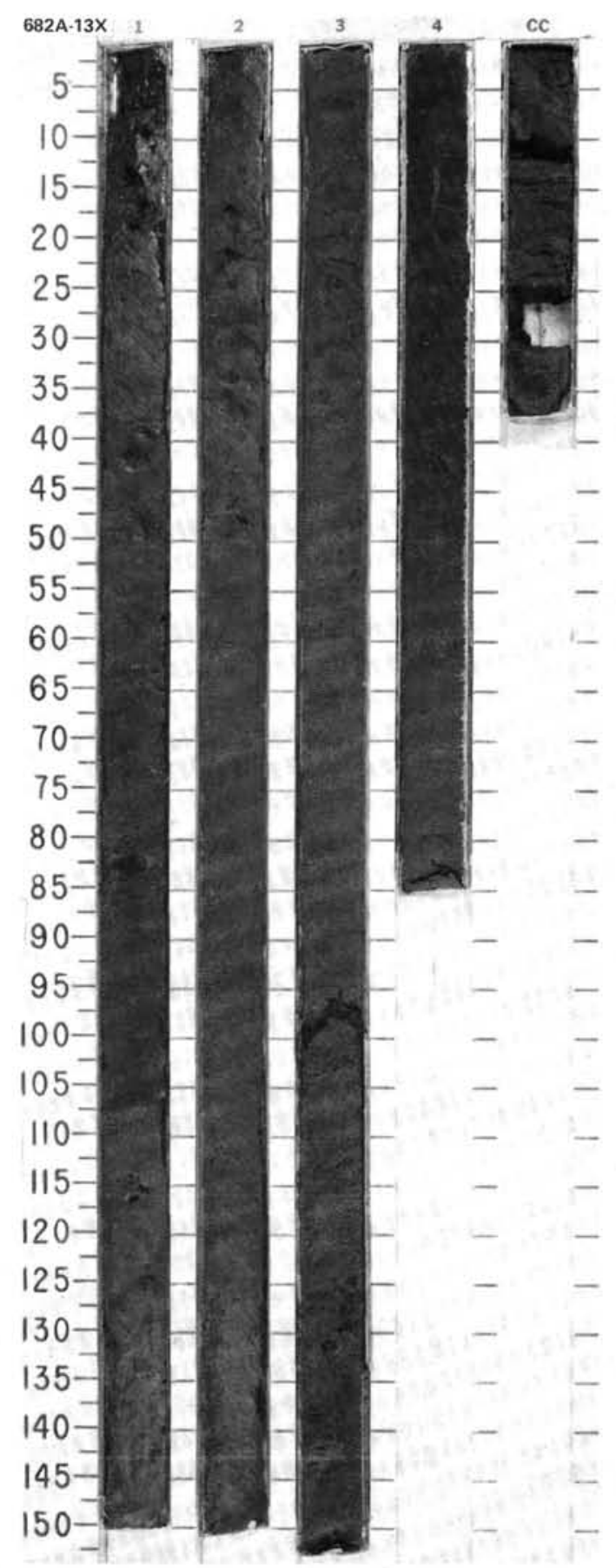




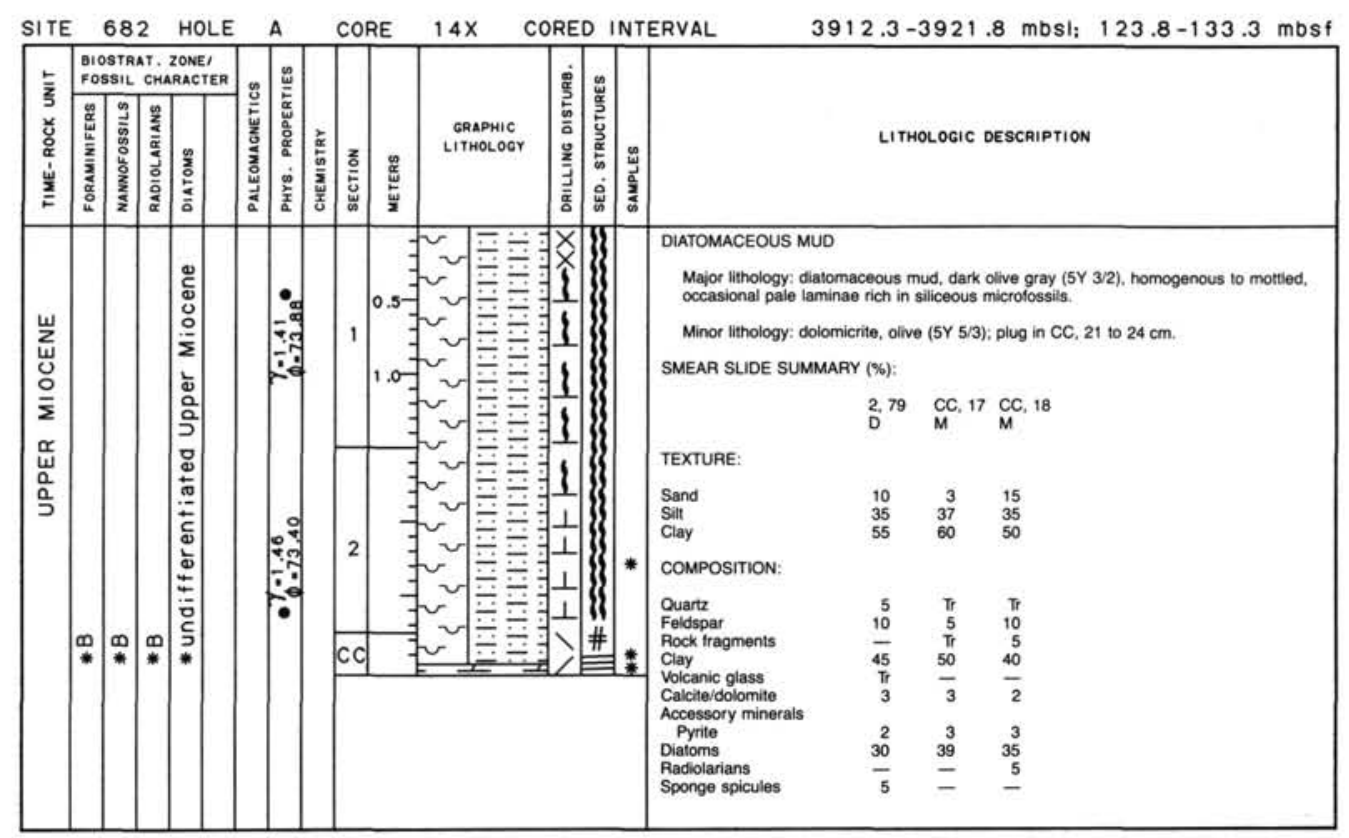

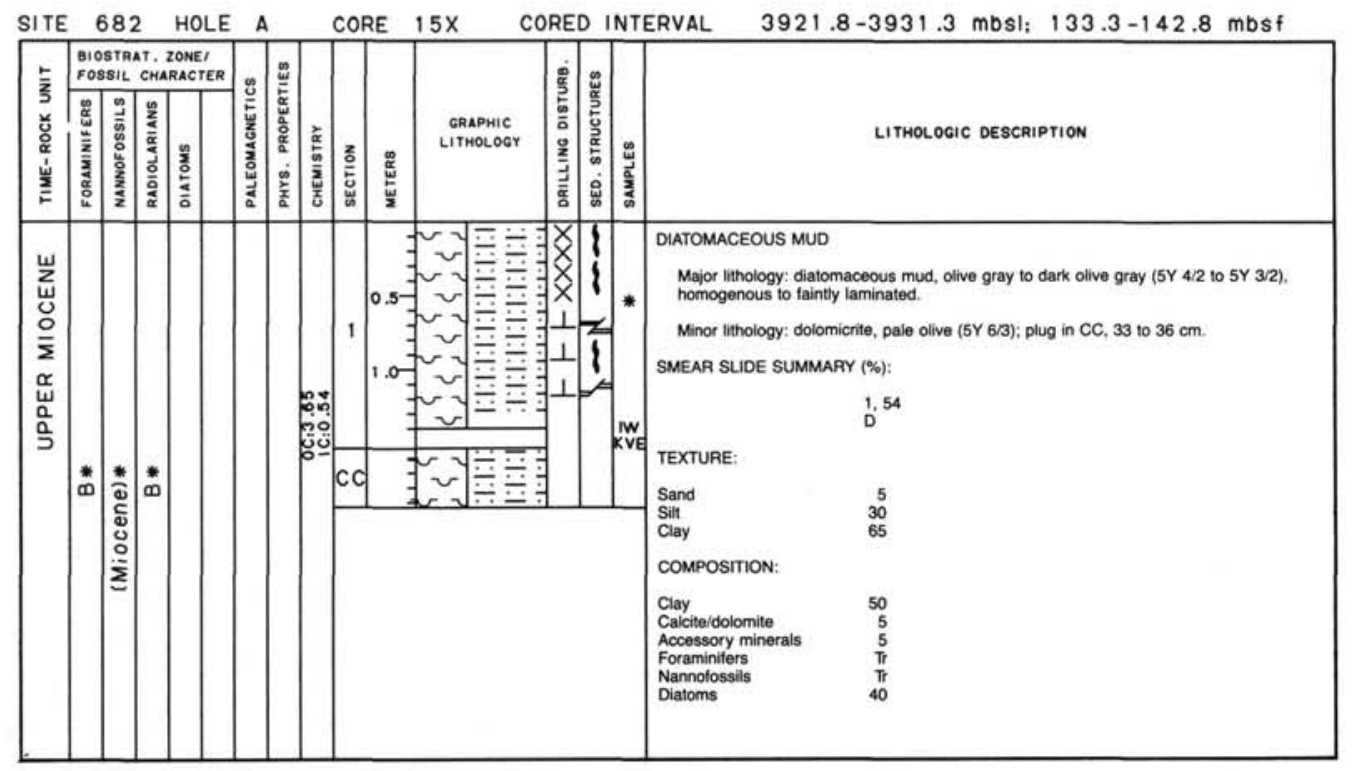
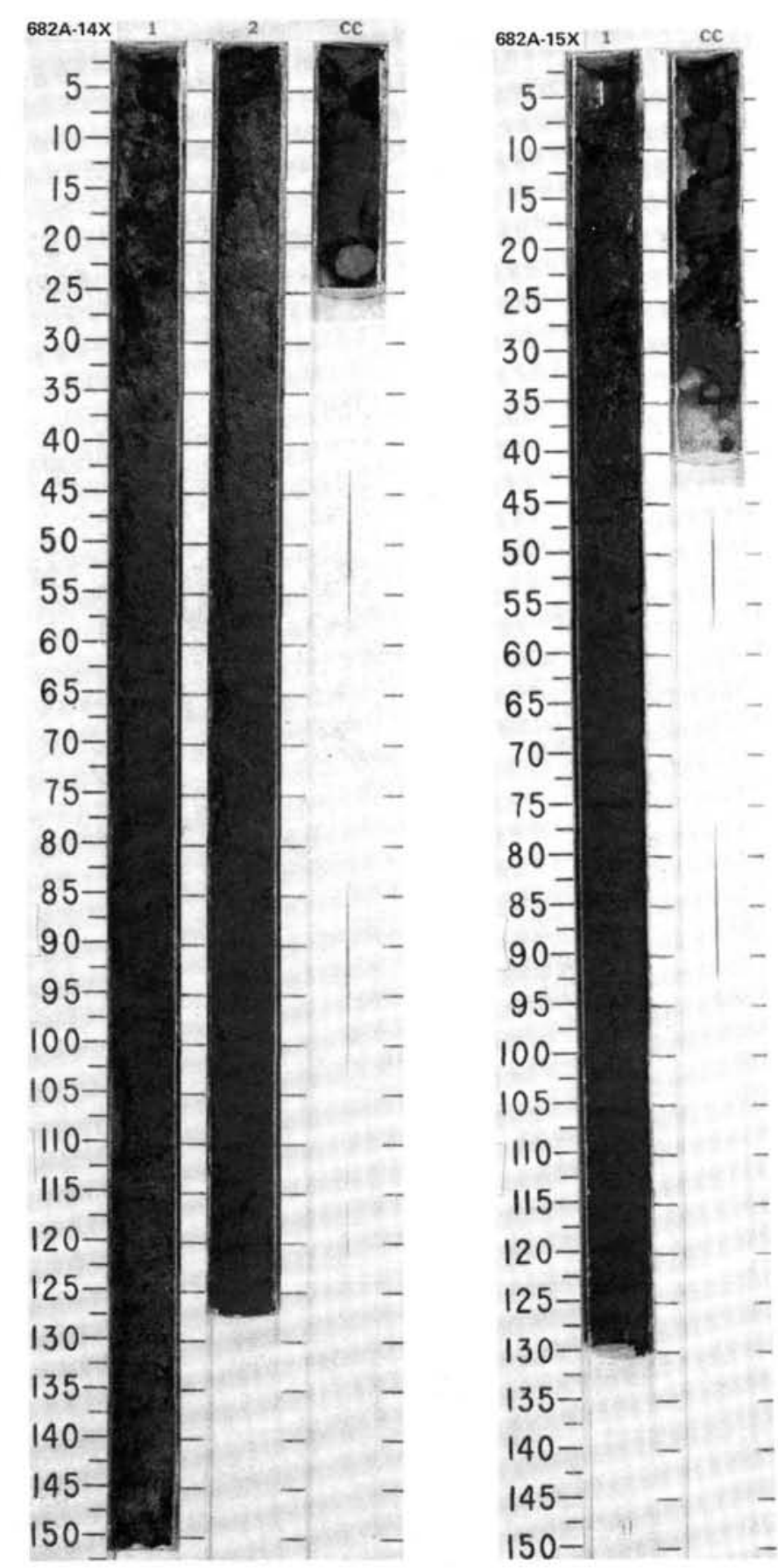

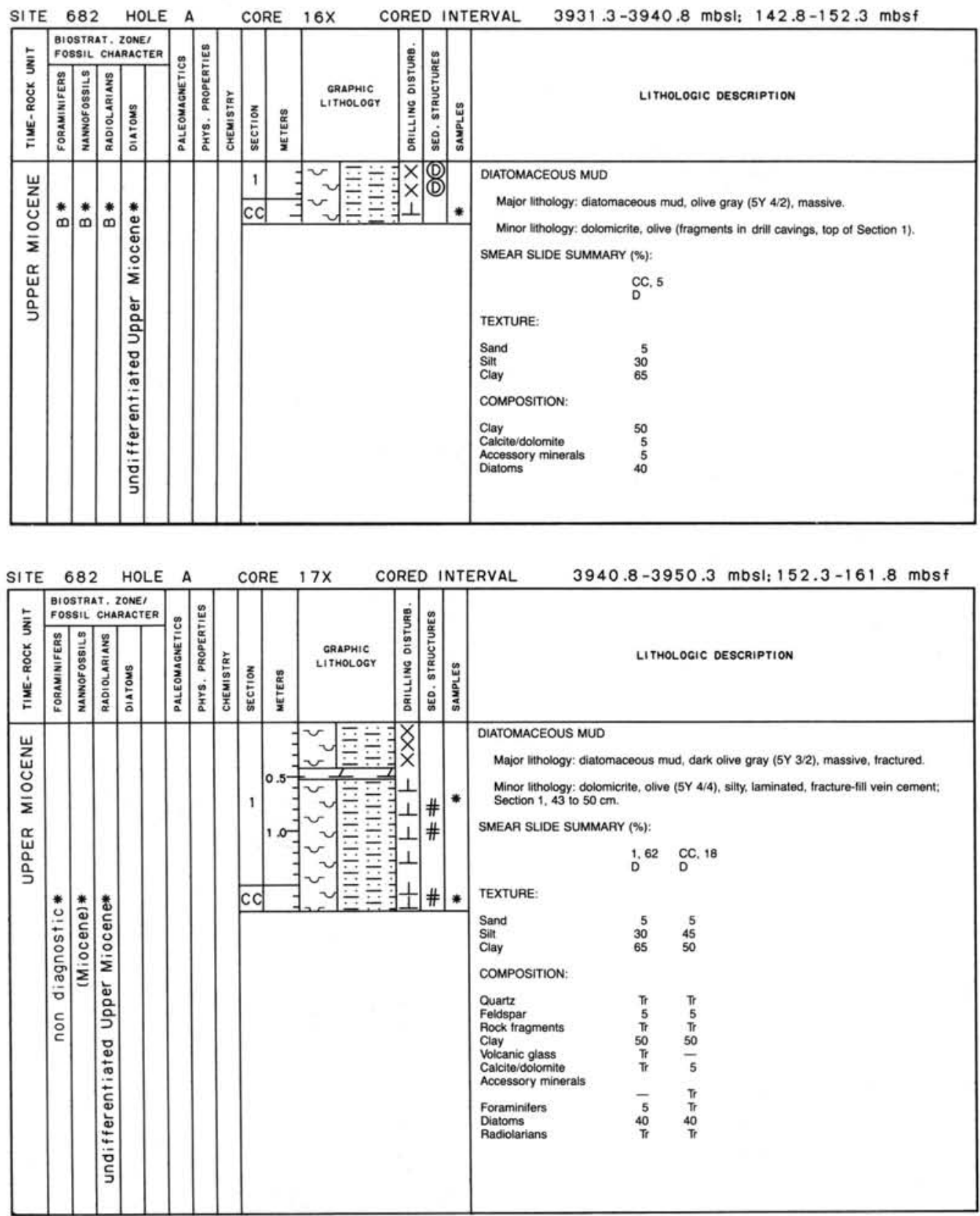

t

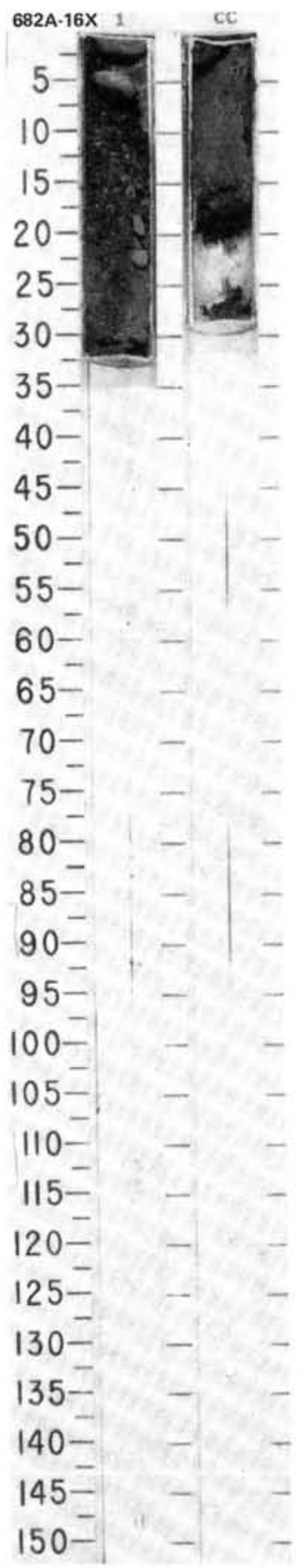

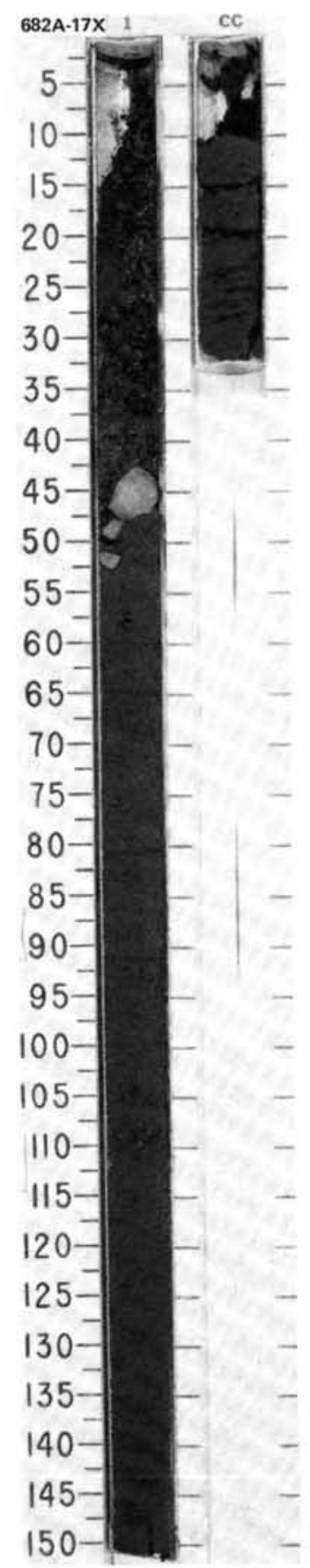



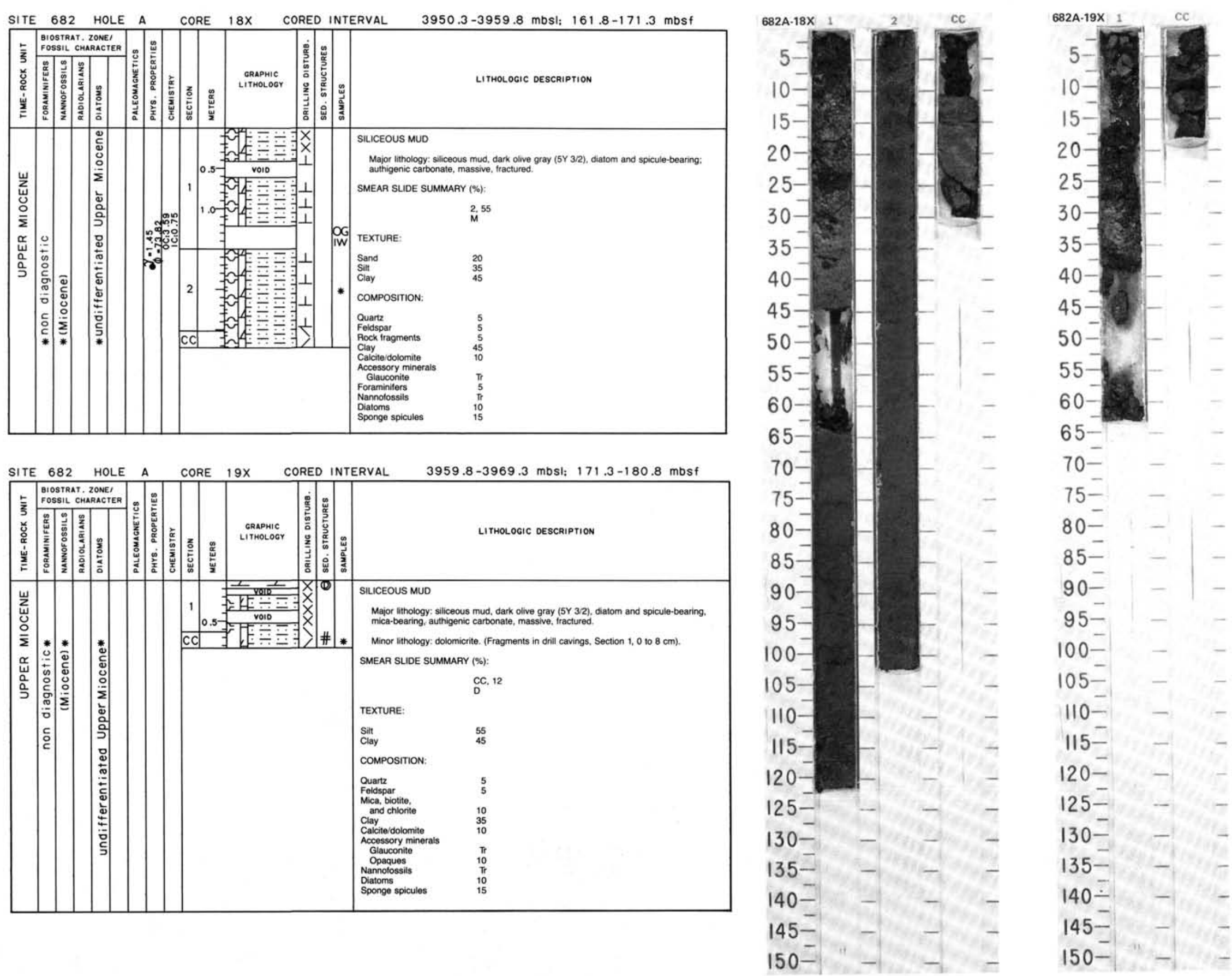

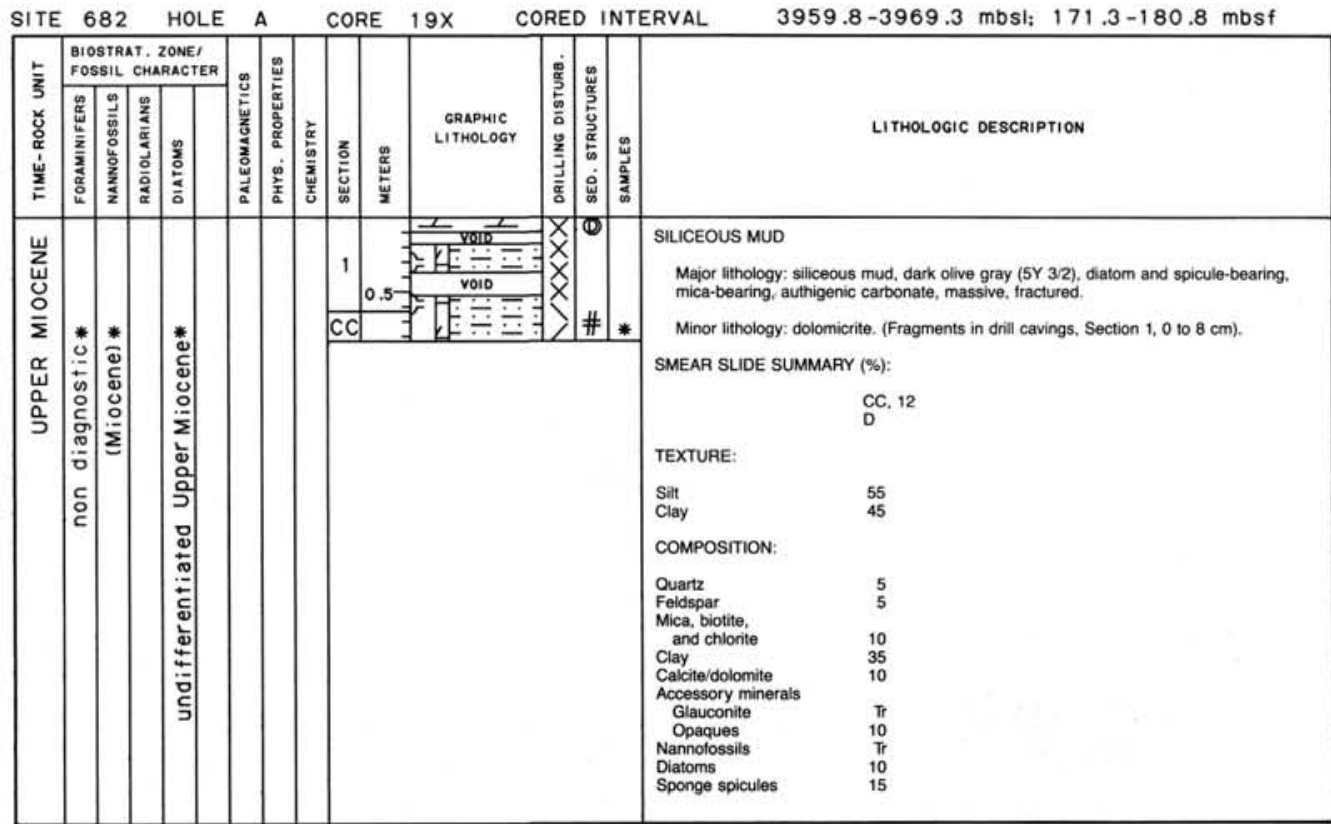



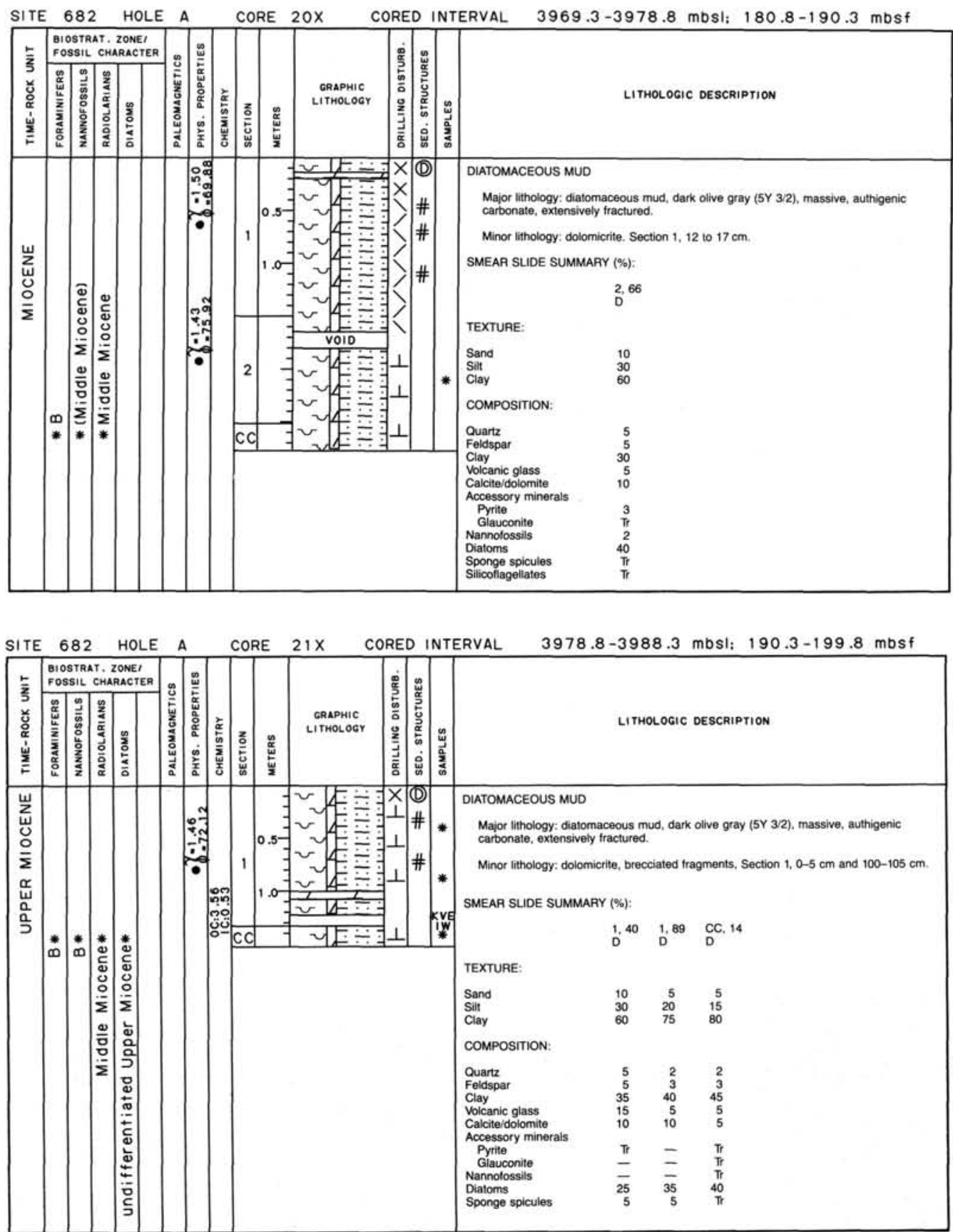

E

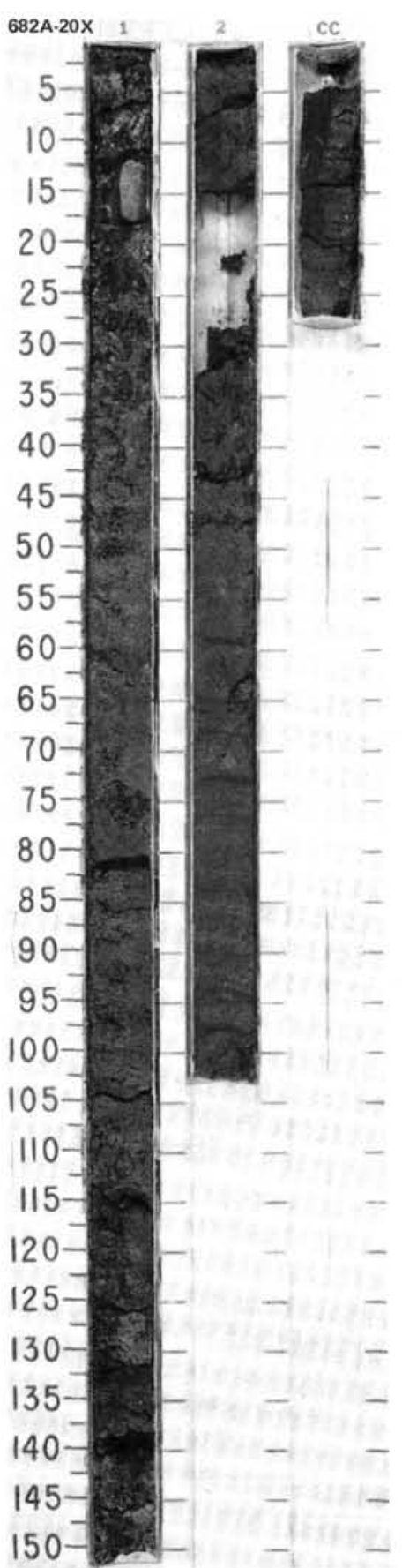

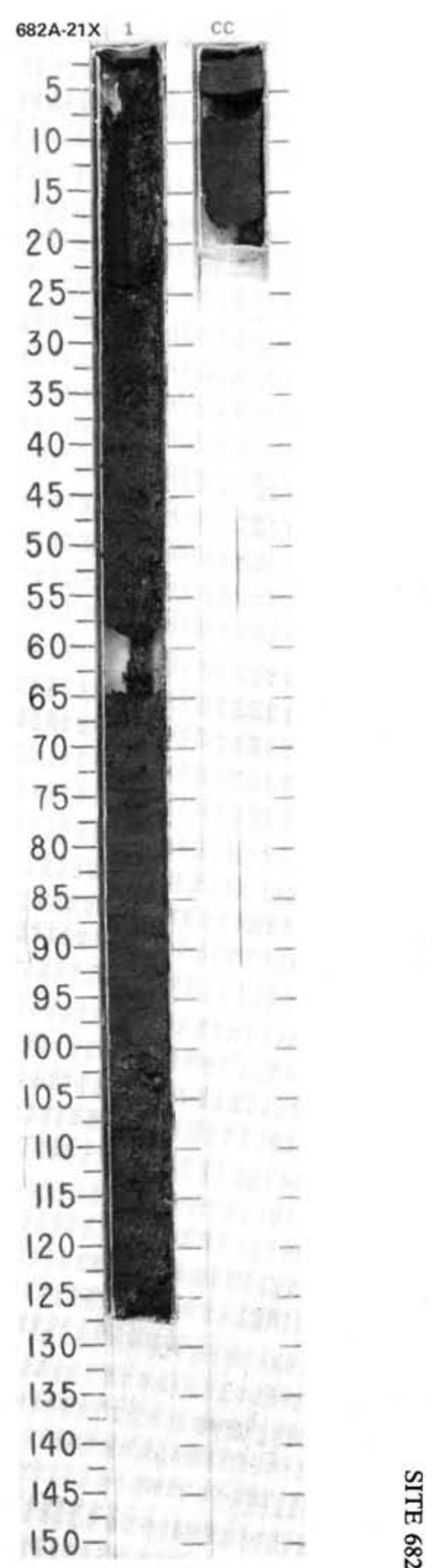



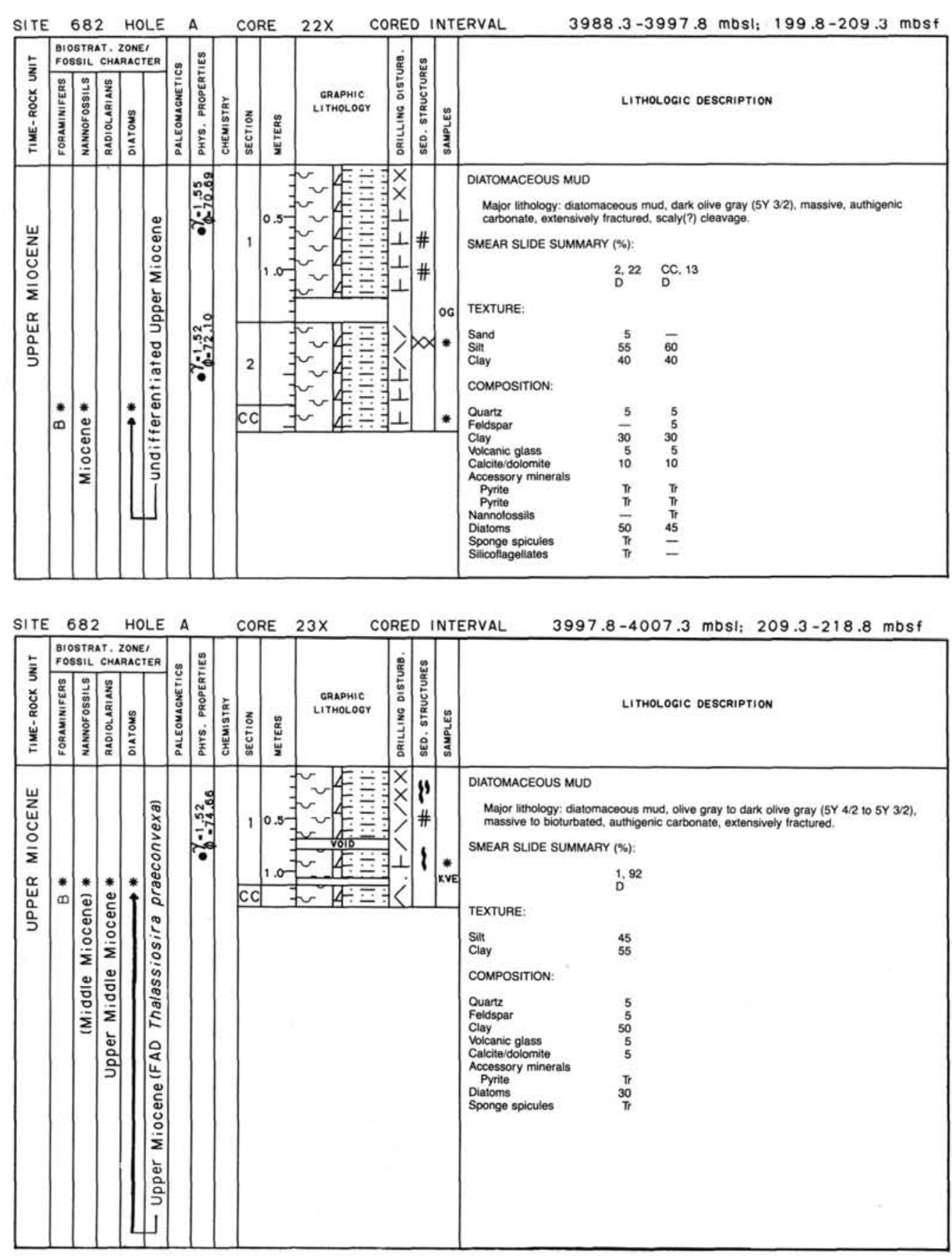

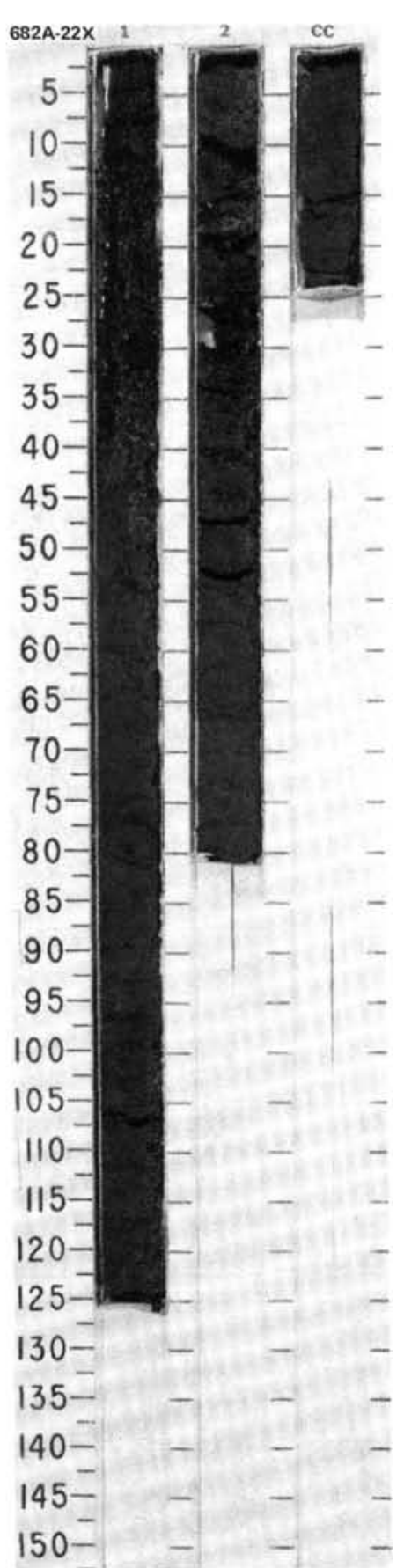



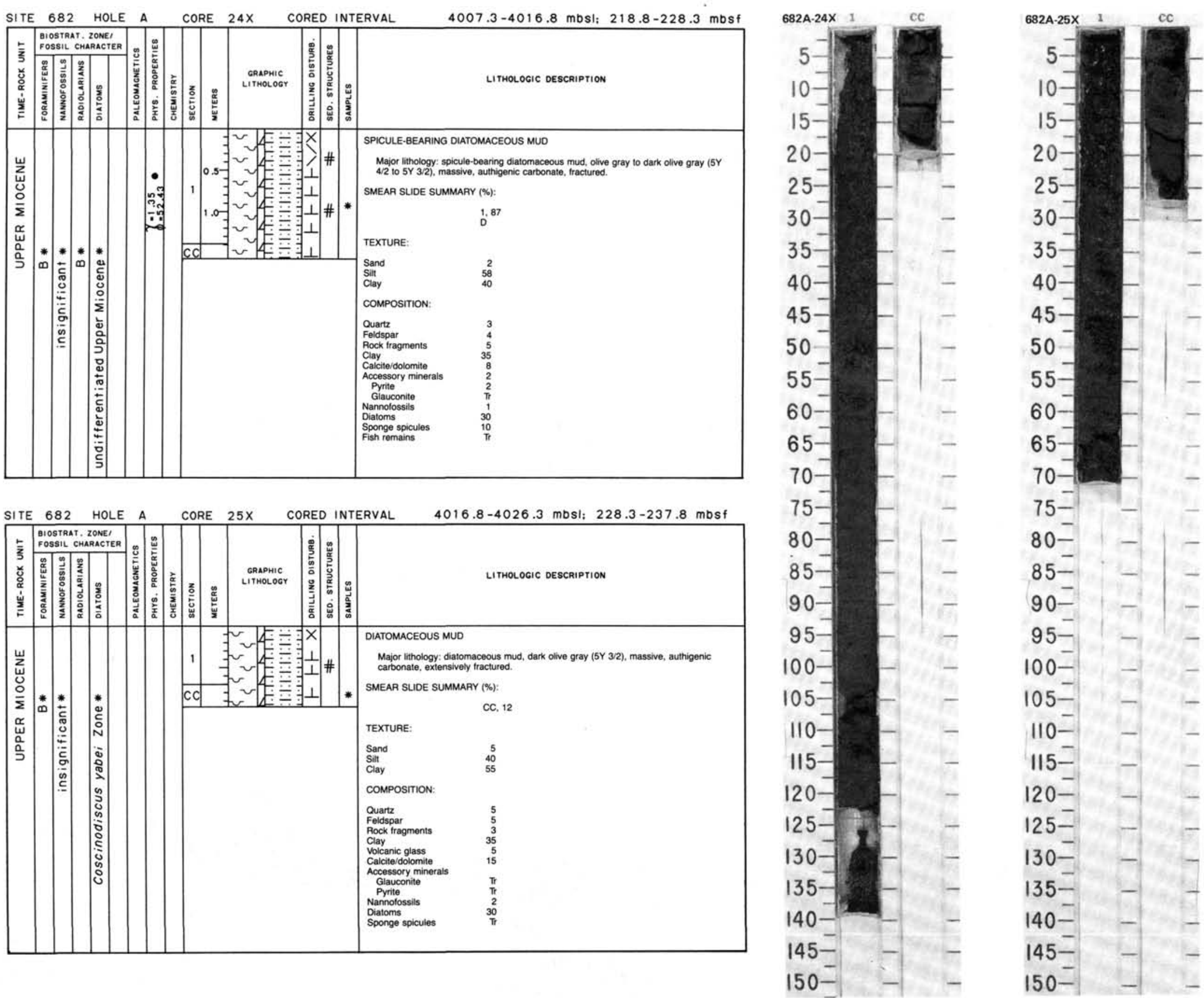

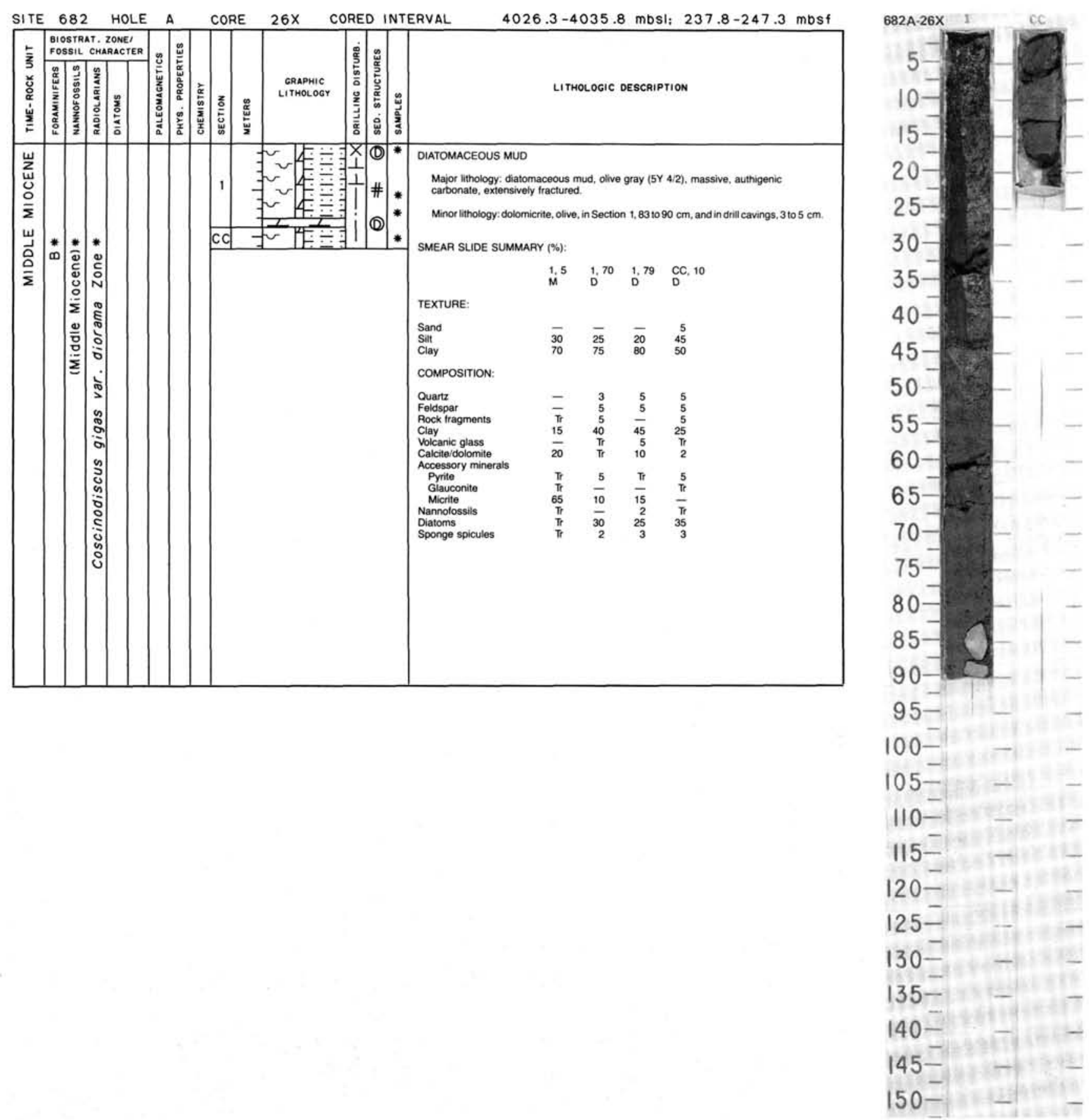


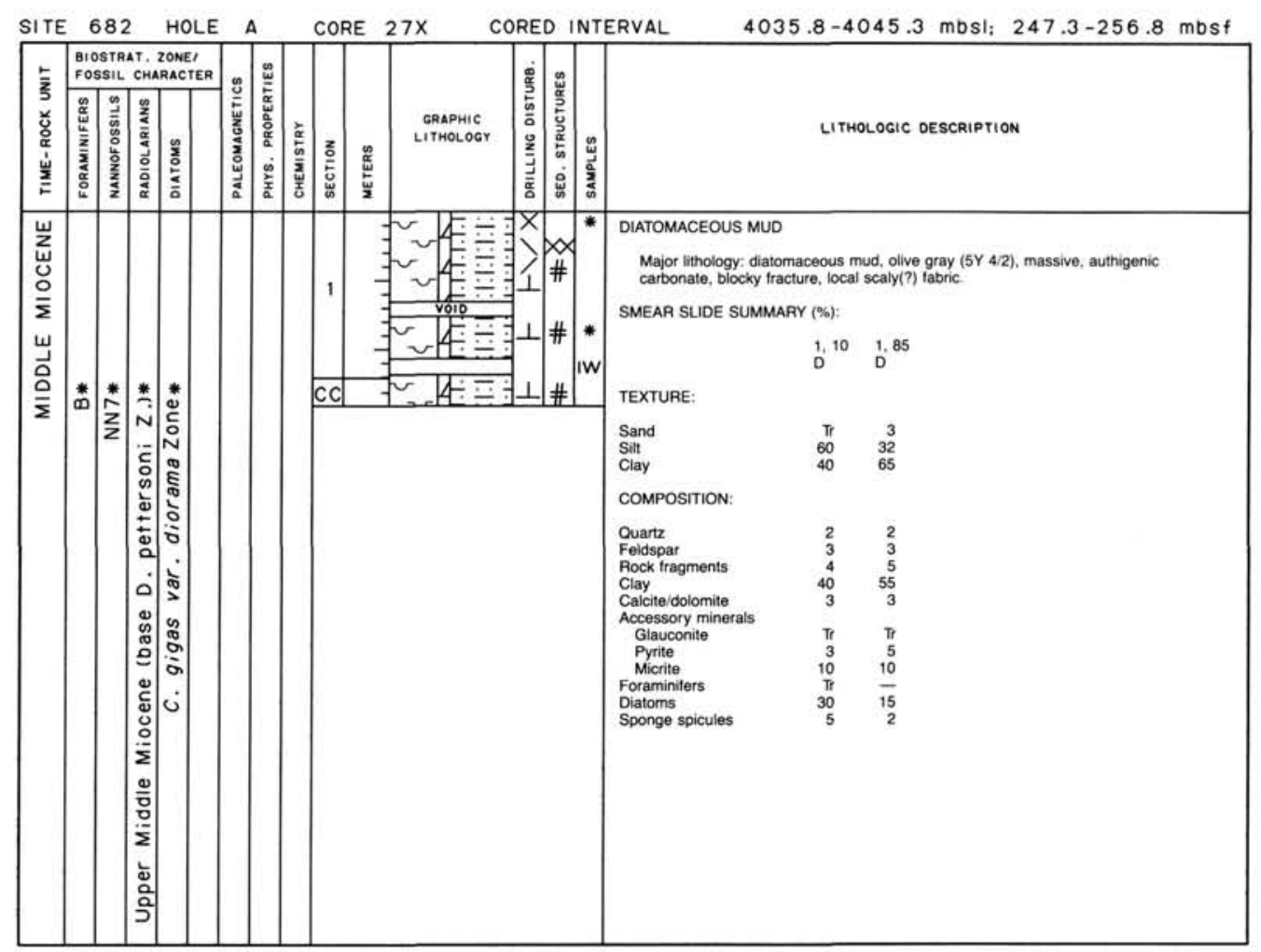

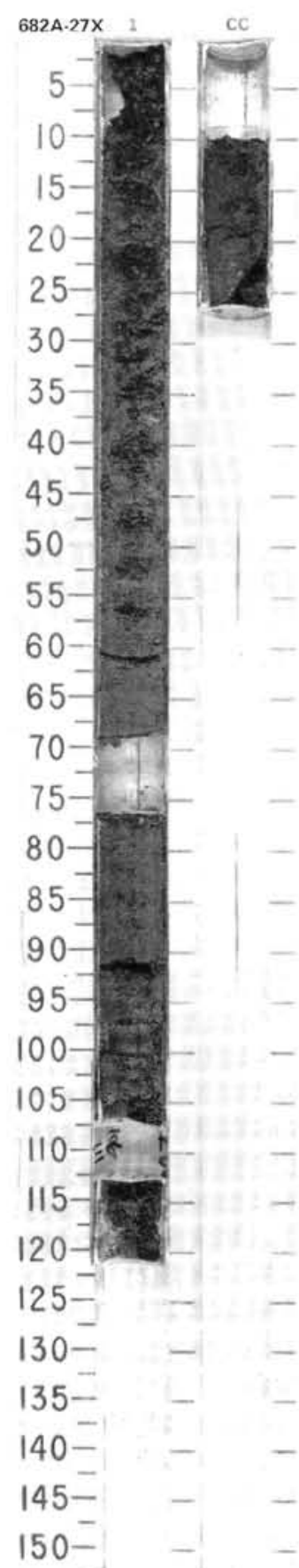



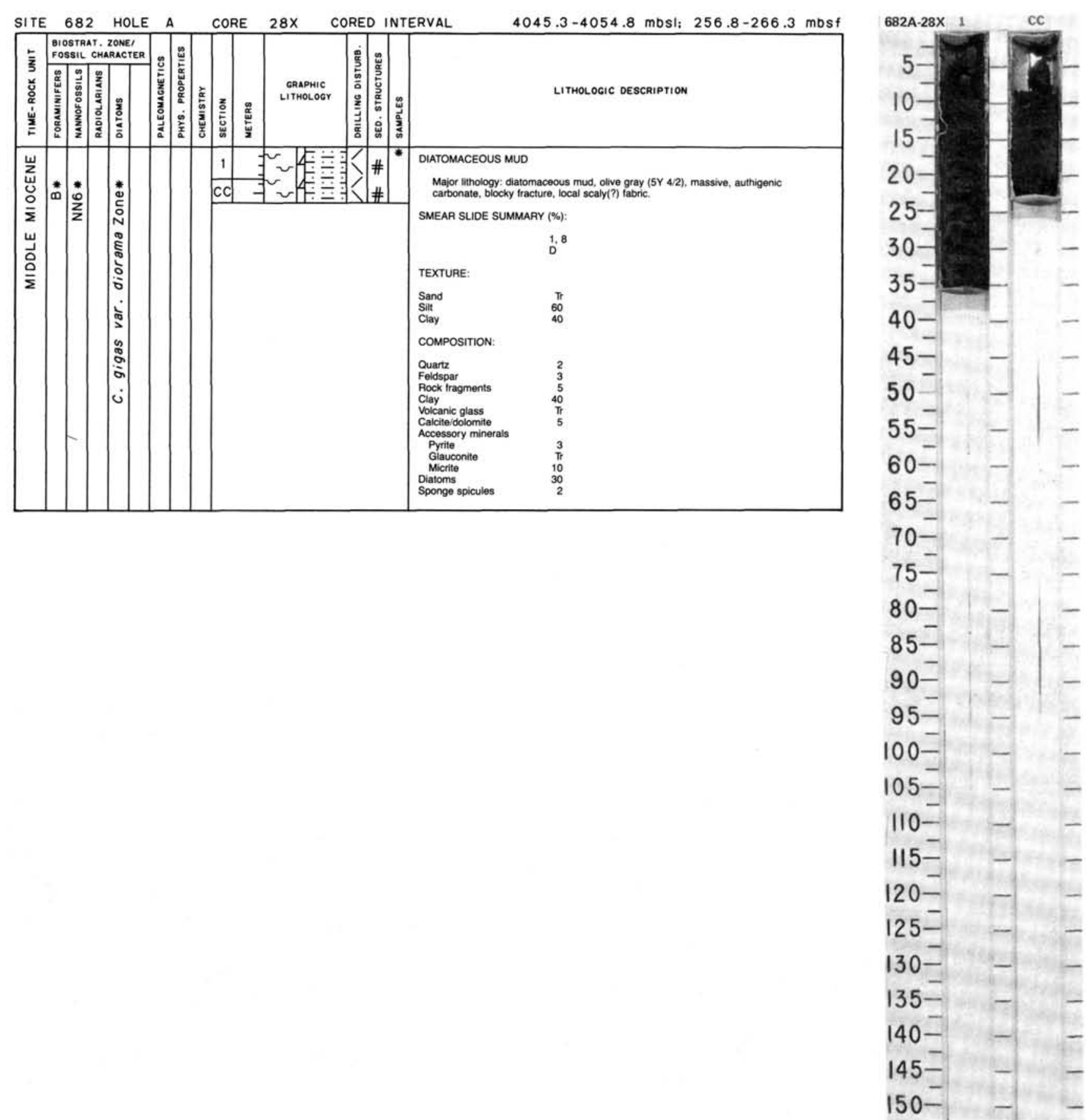


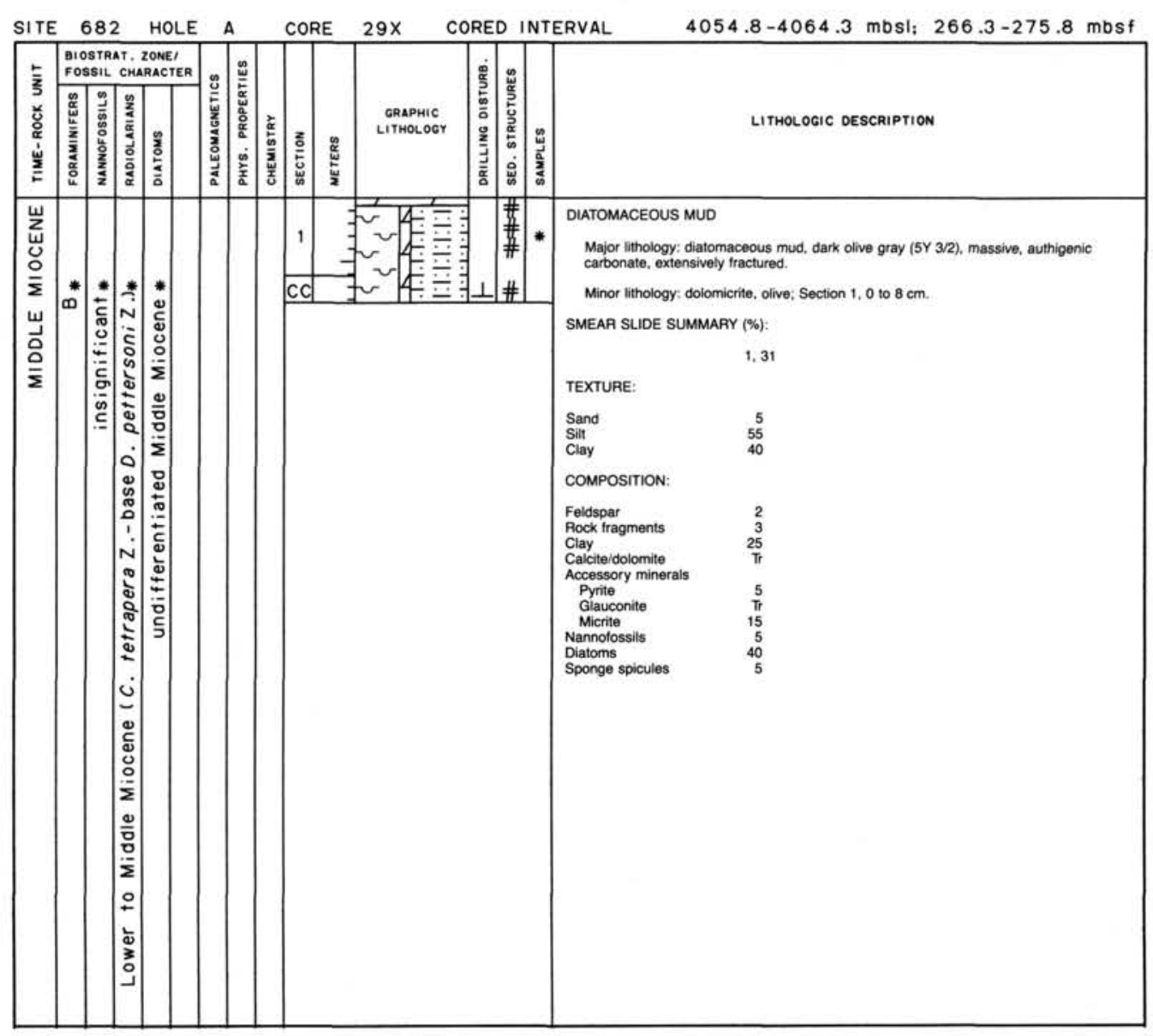

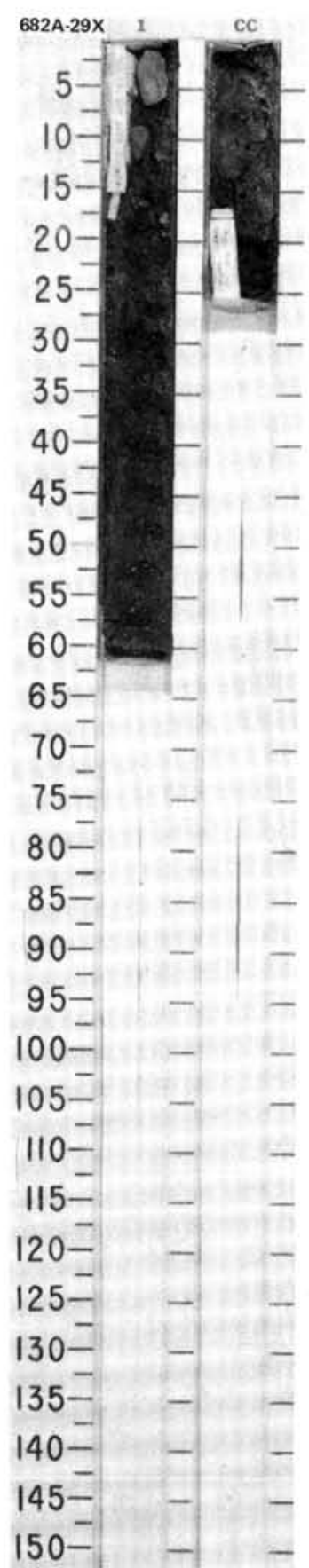



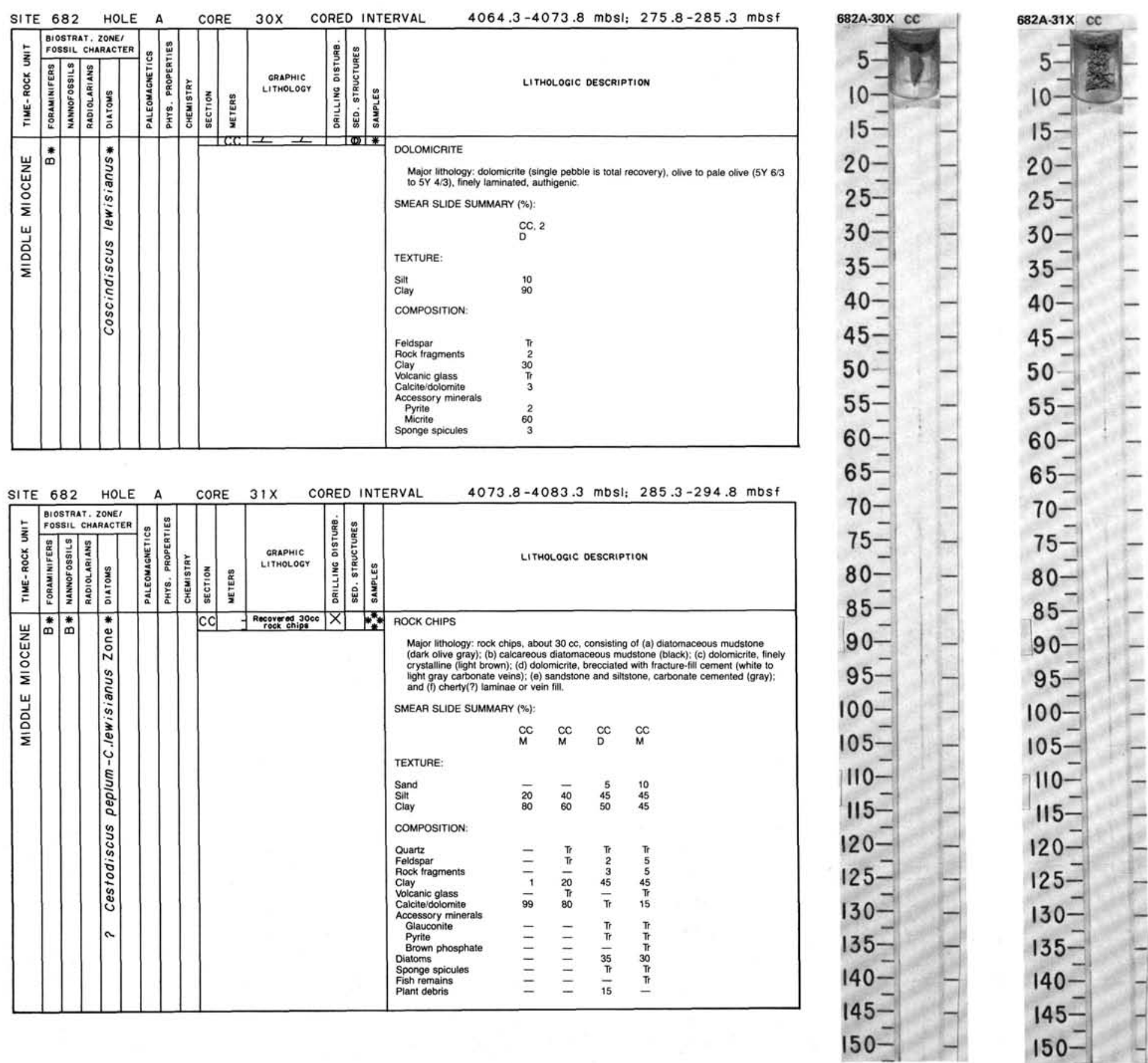

$150=$ 


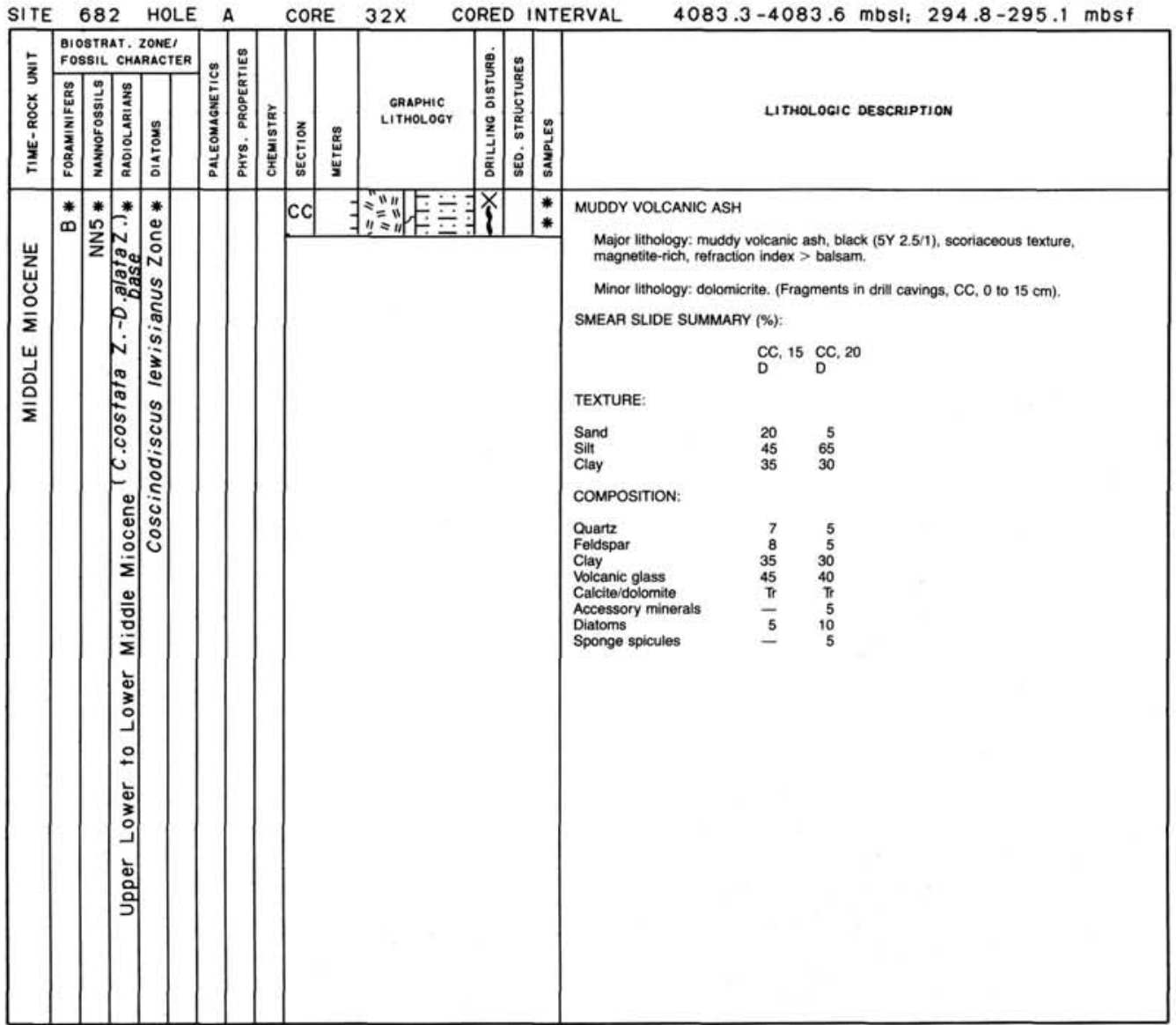

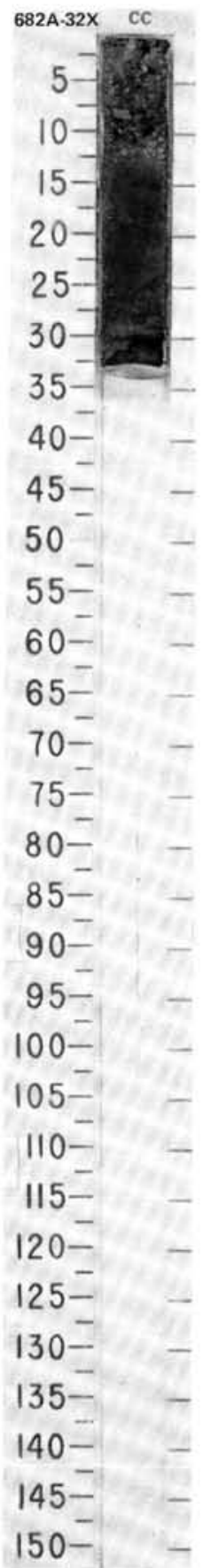




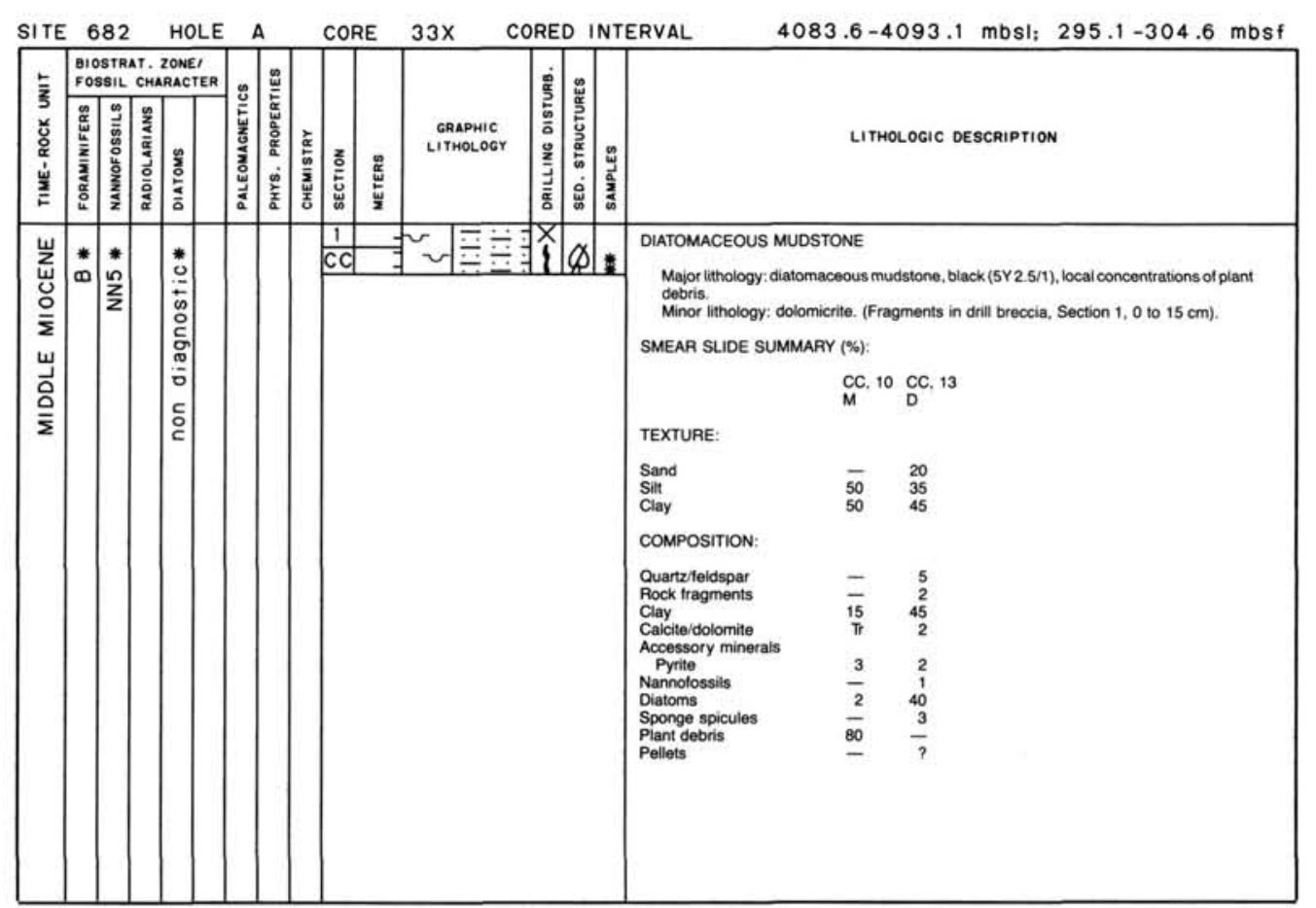

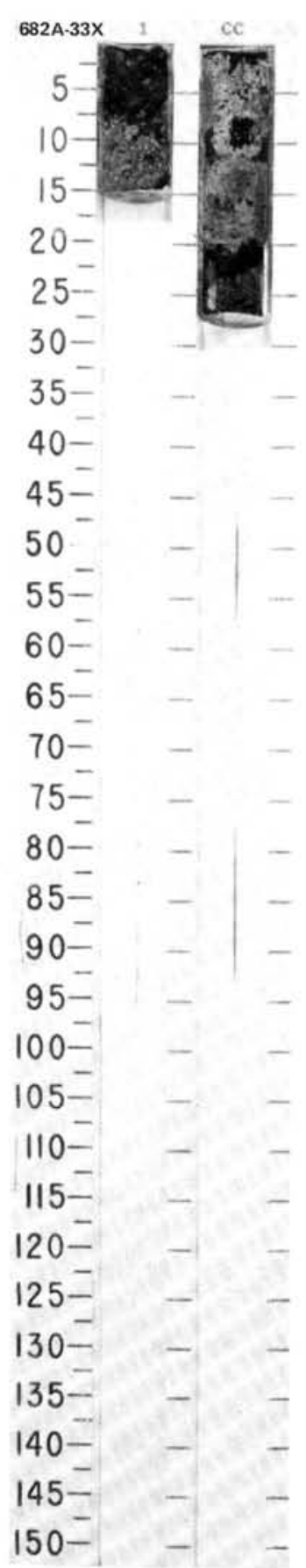




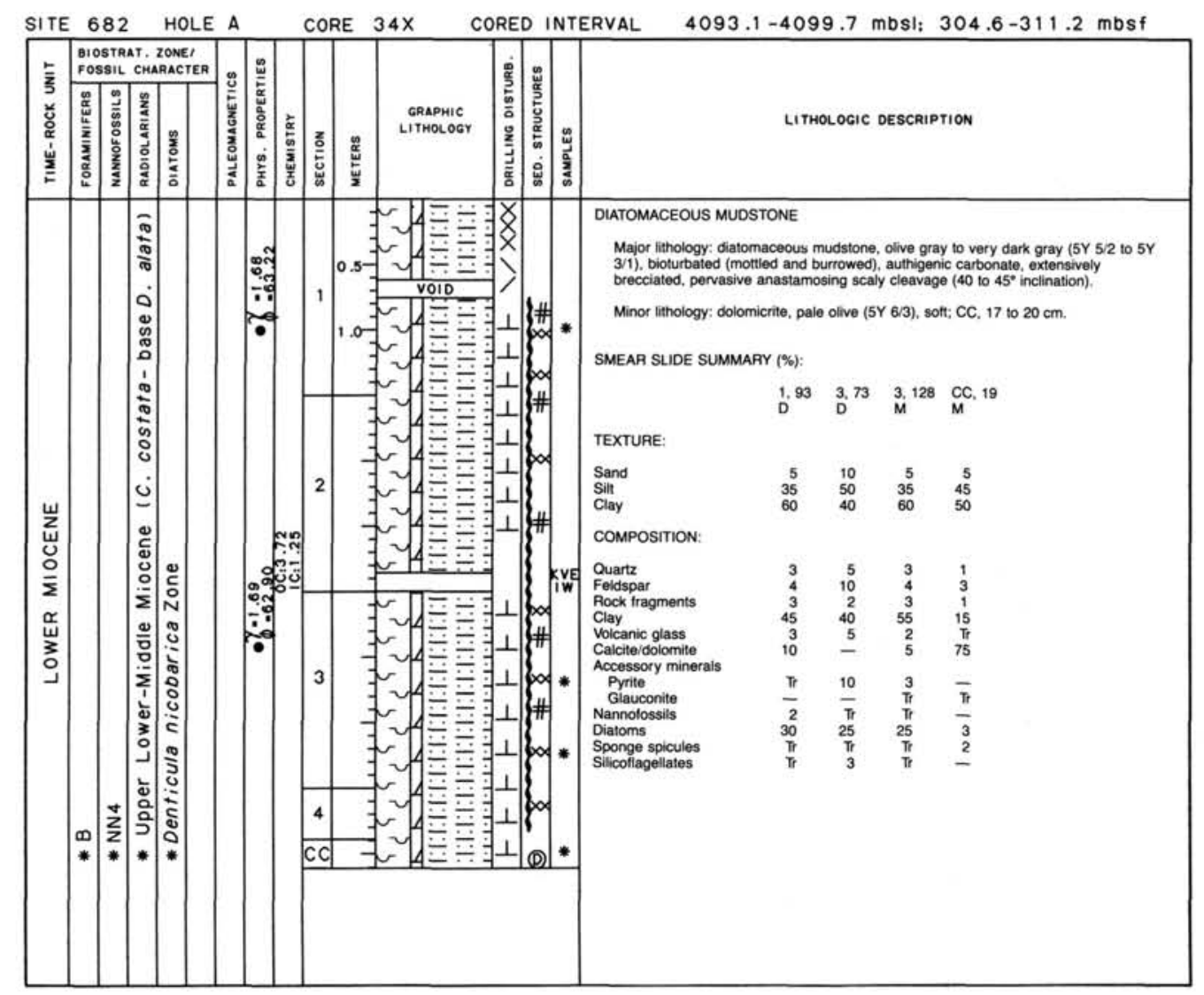

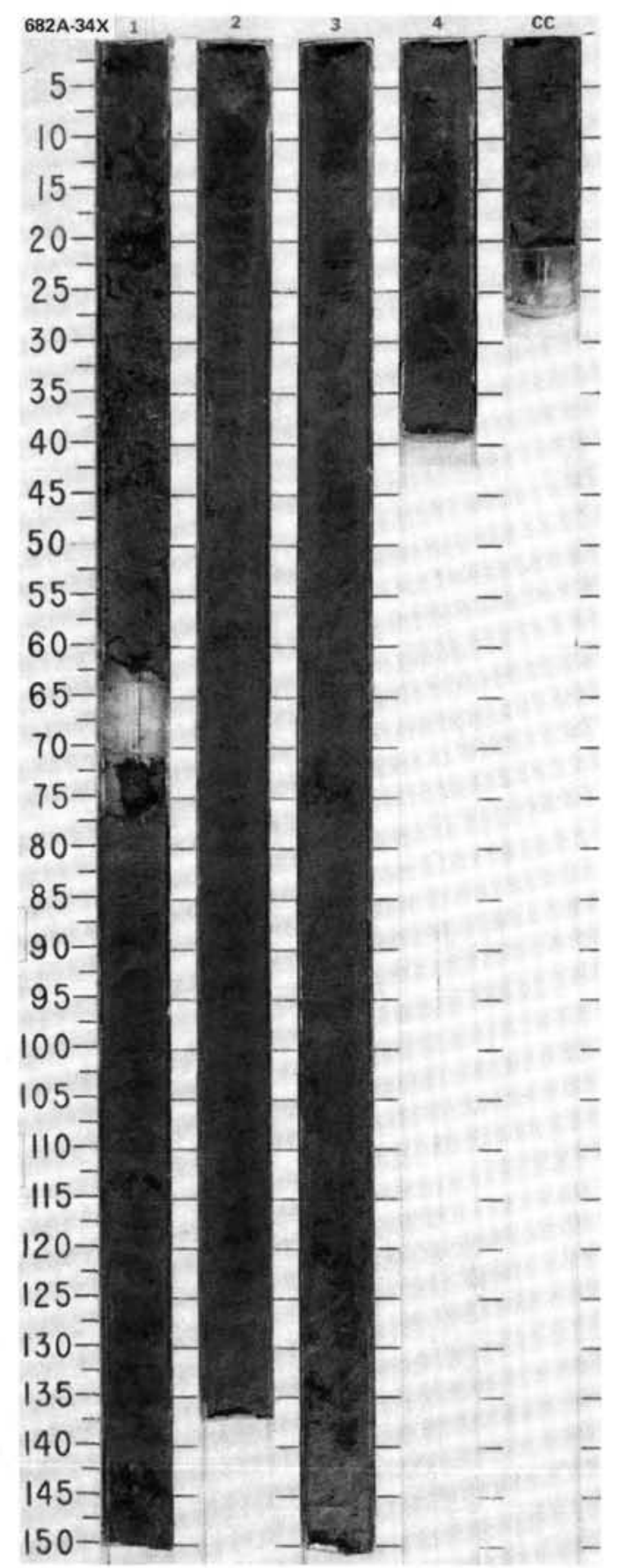



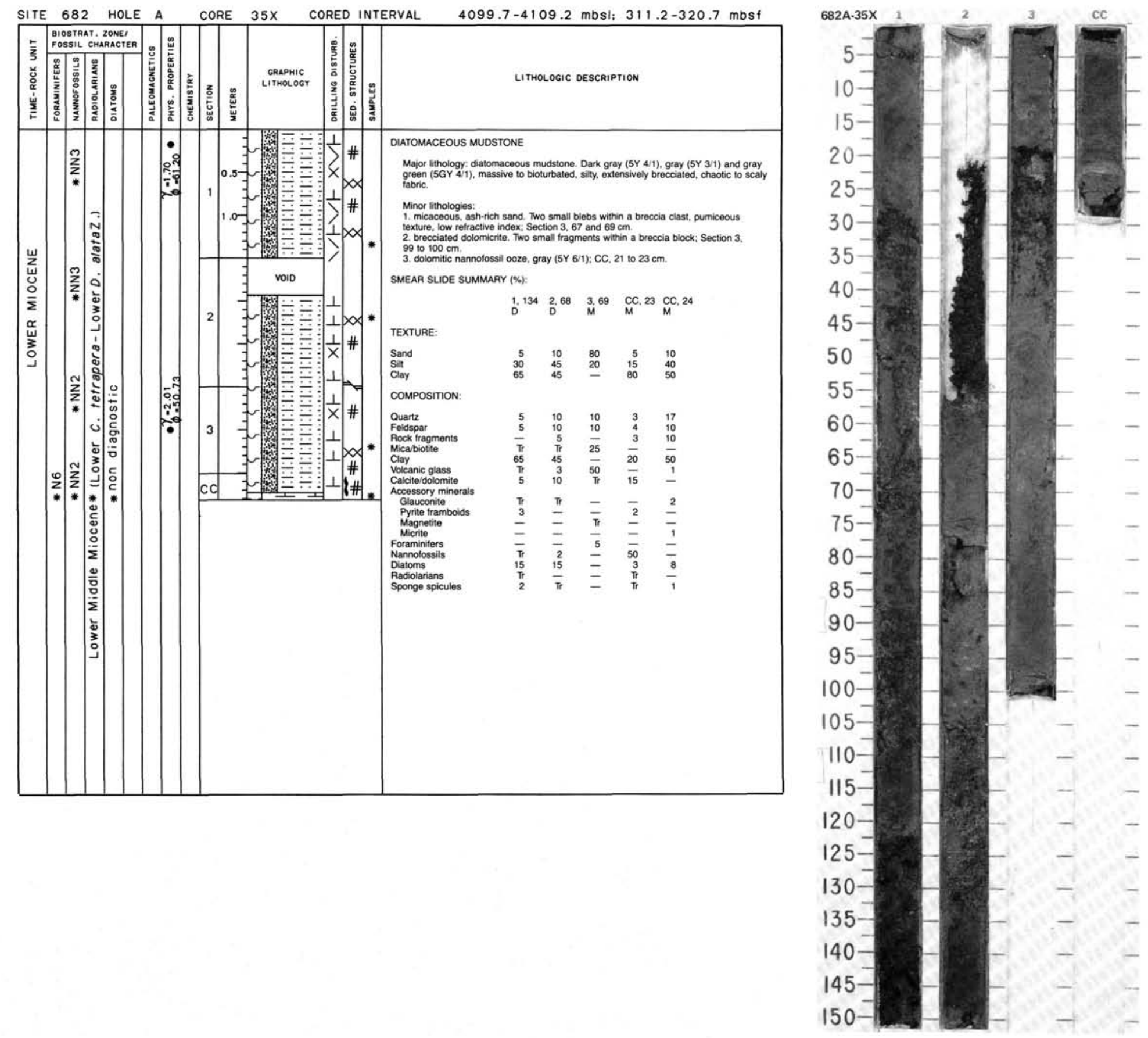

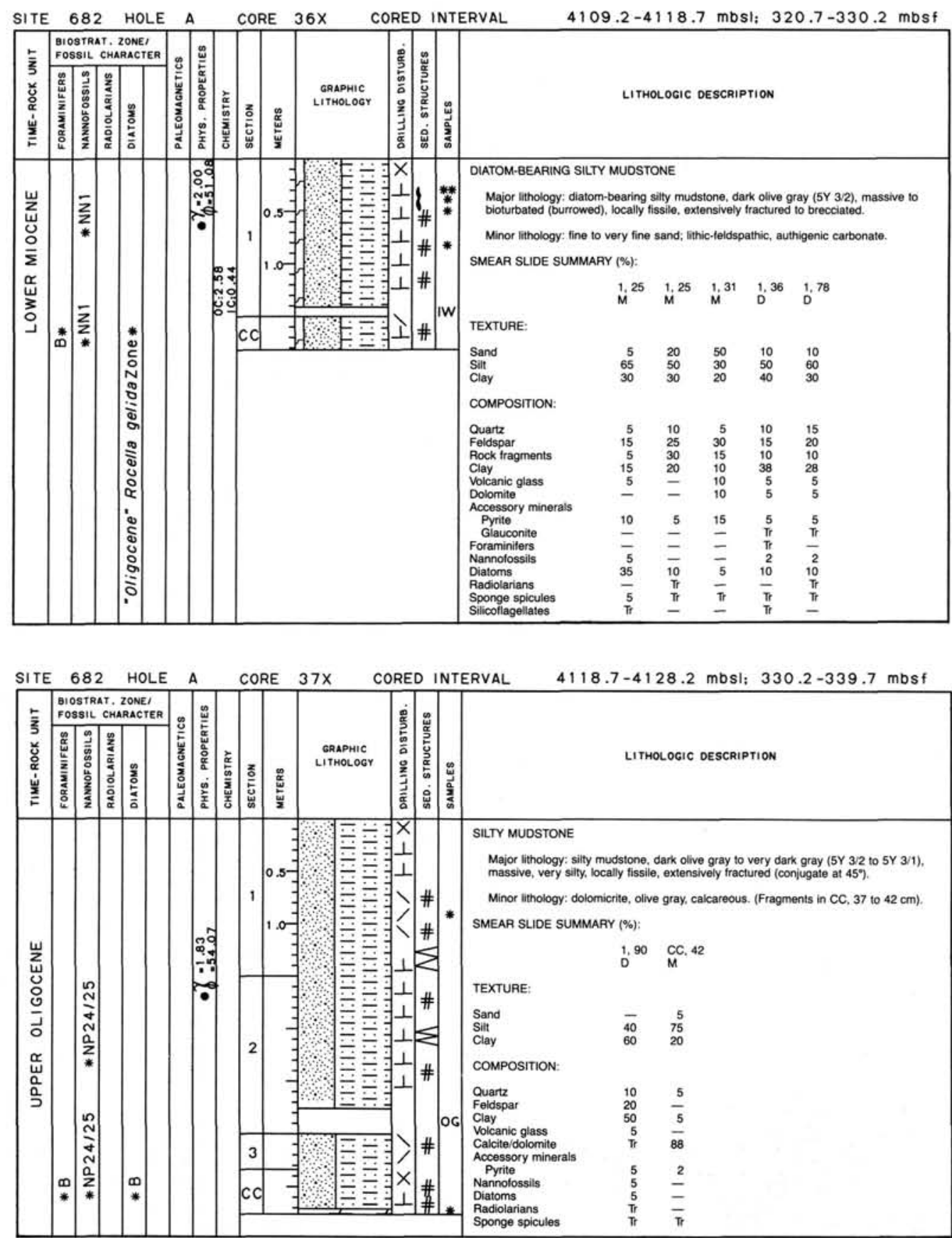

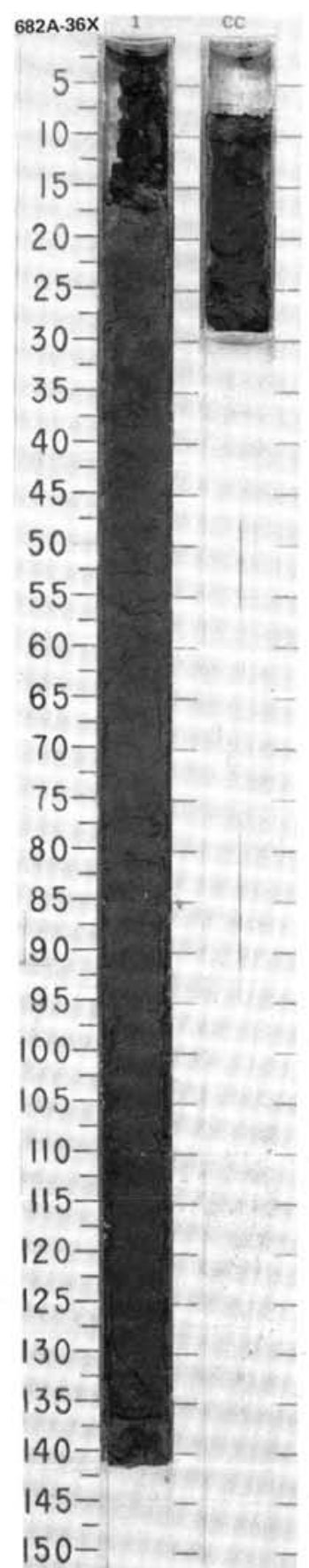




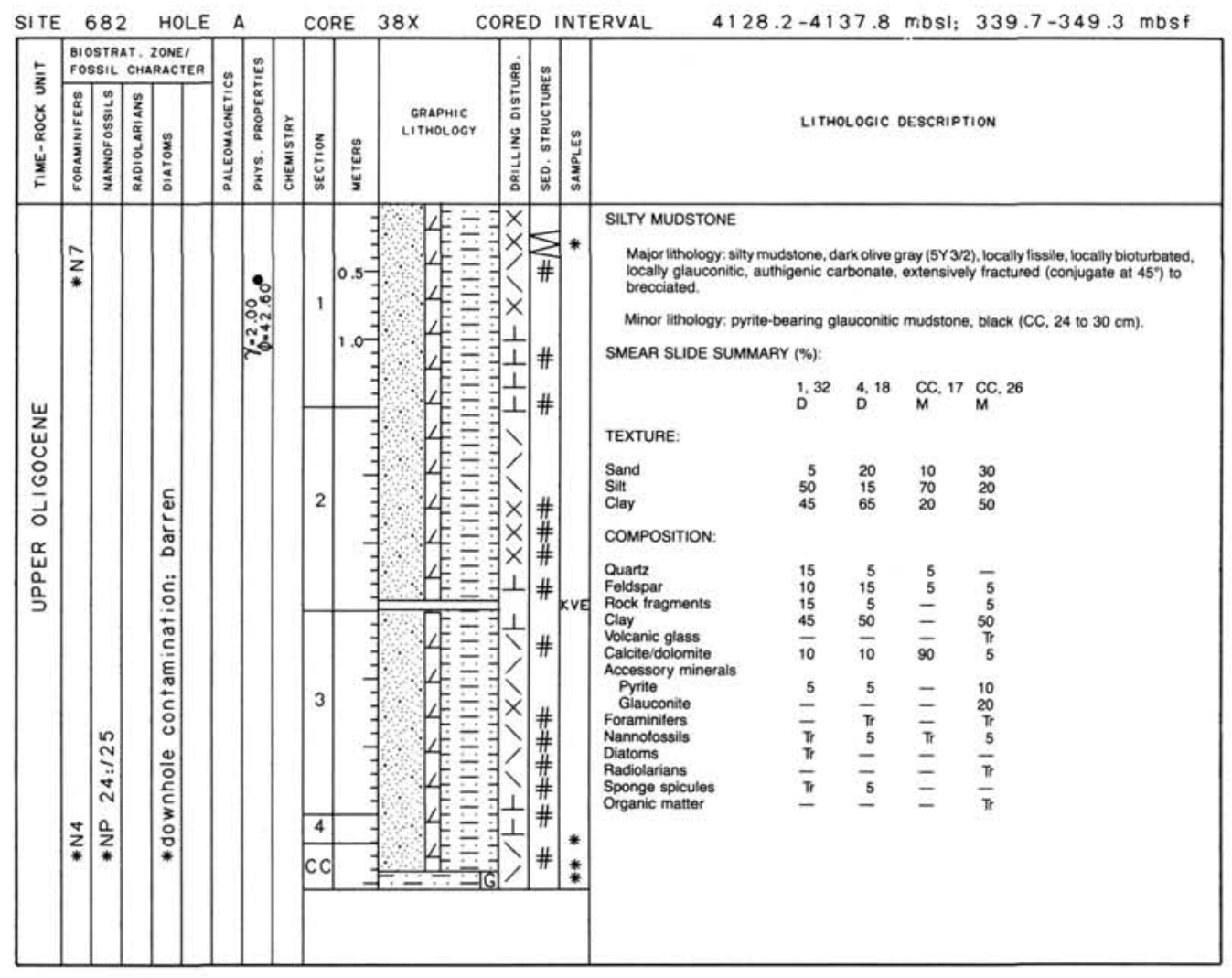

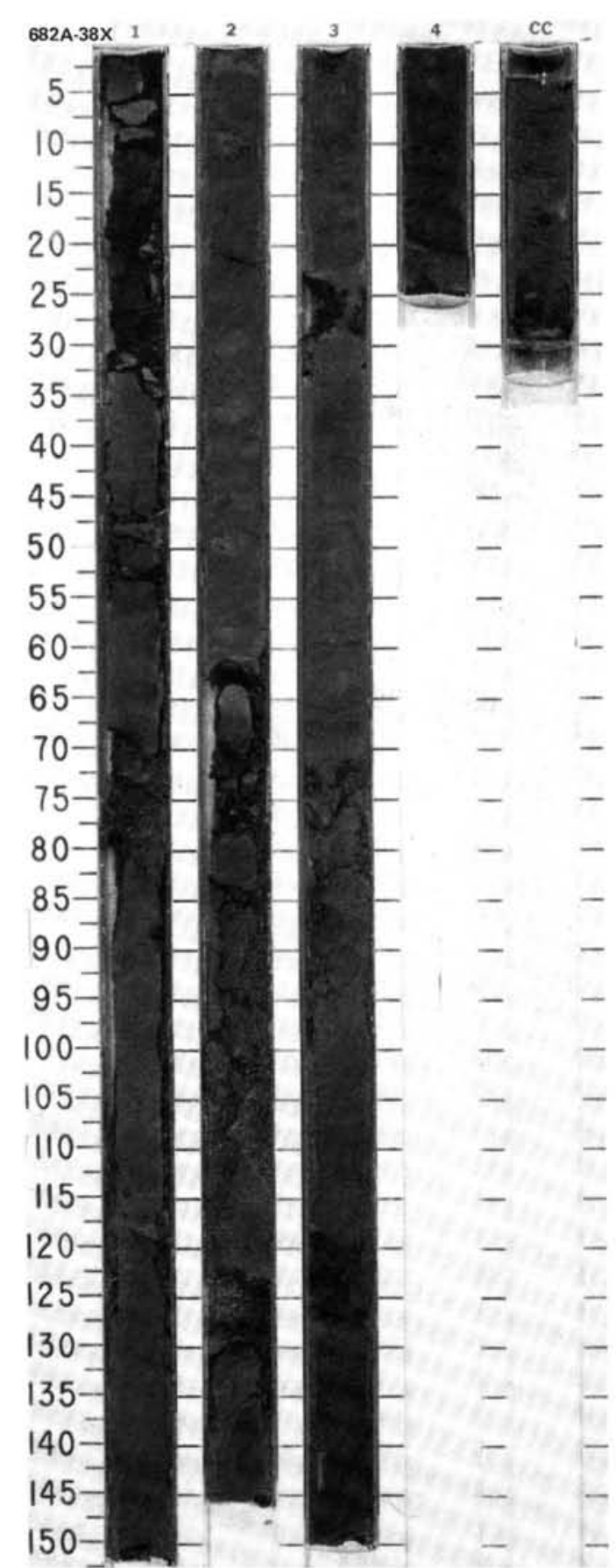




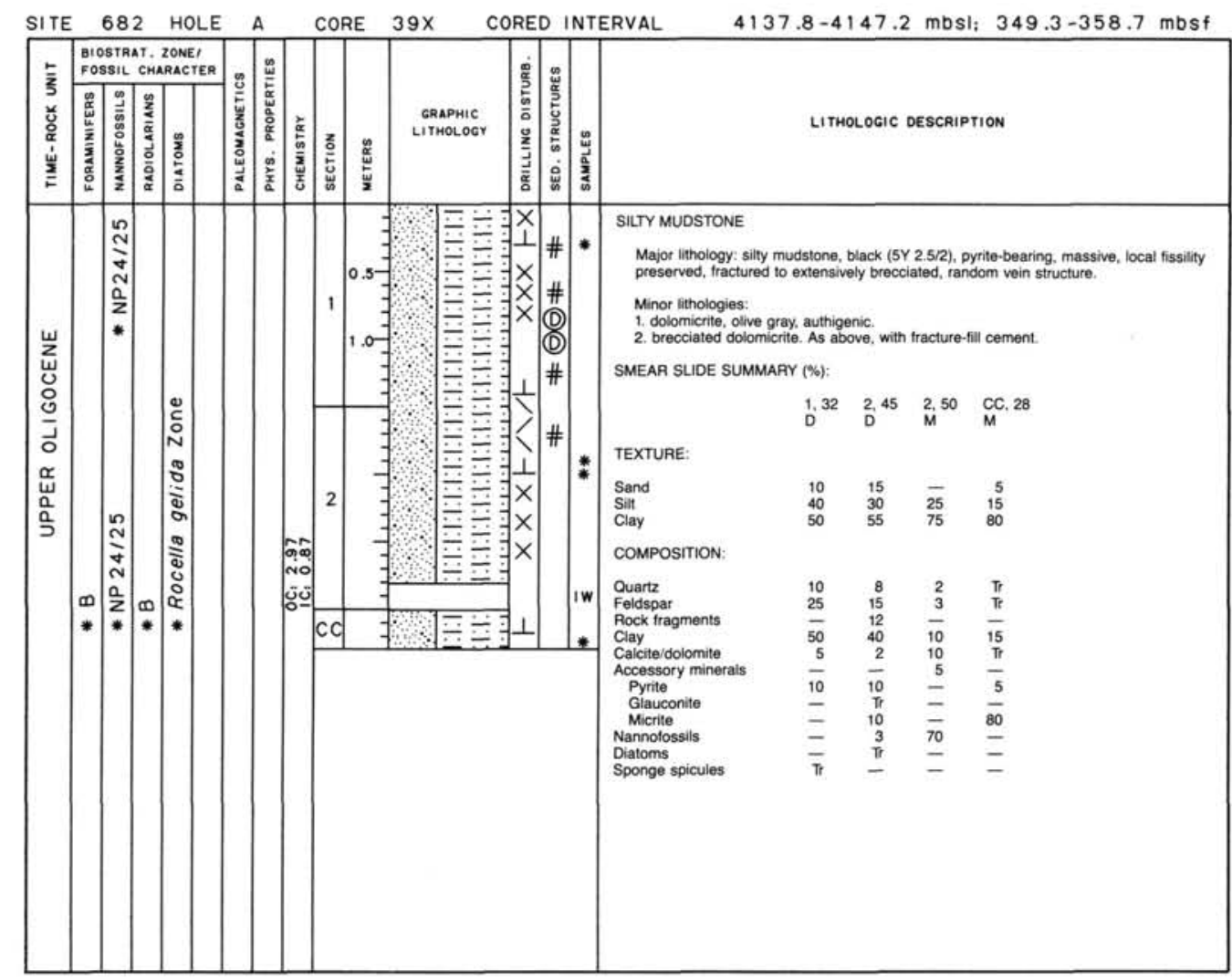

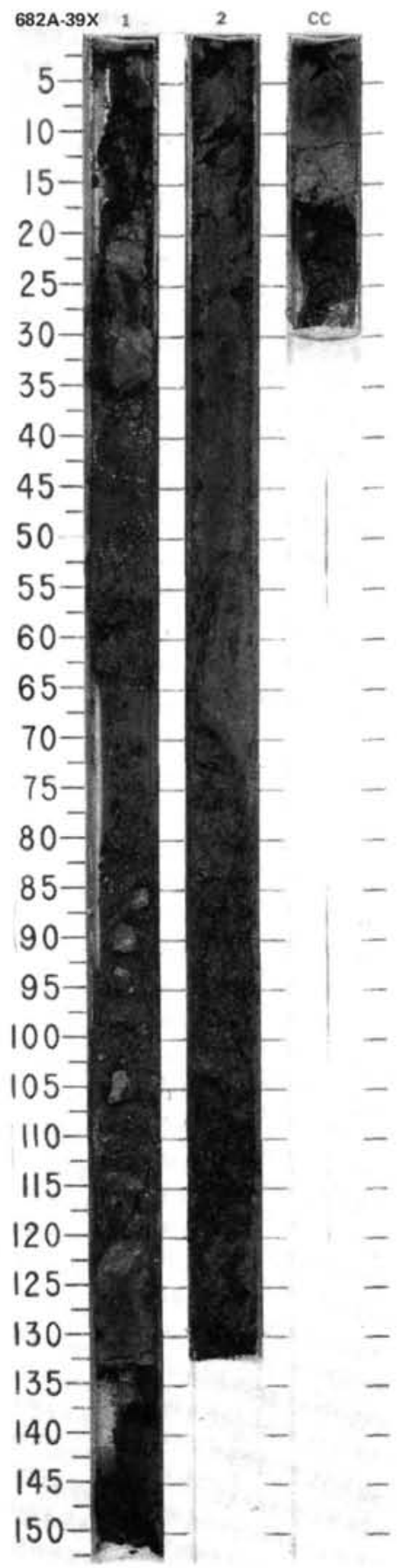



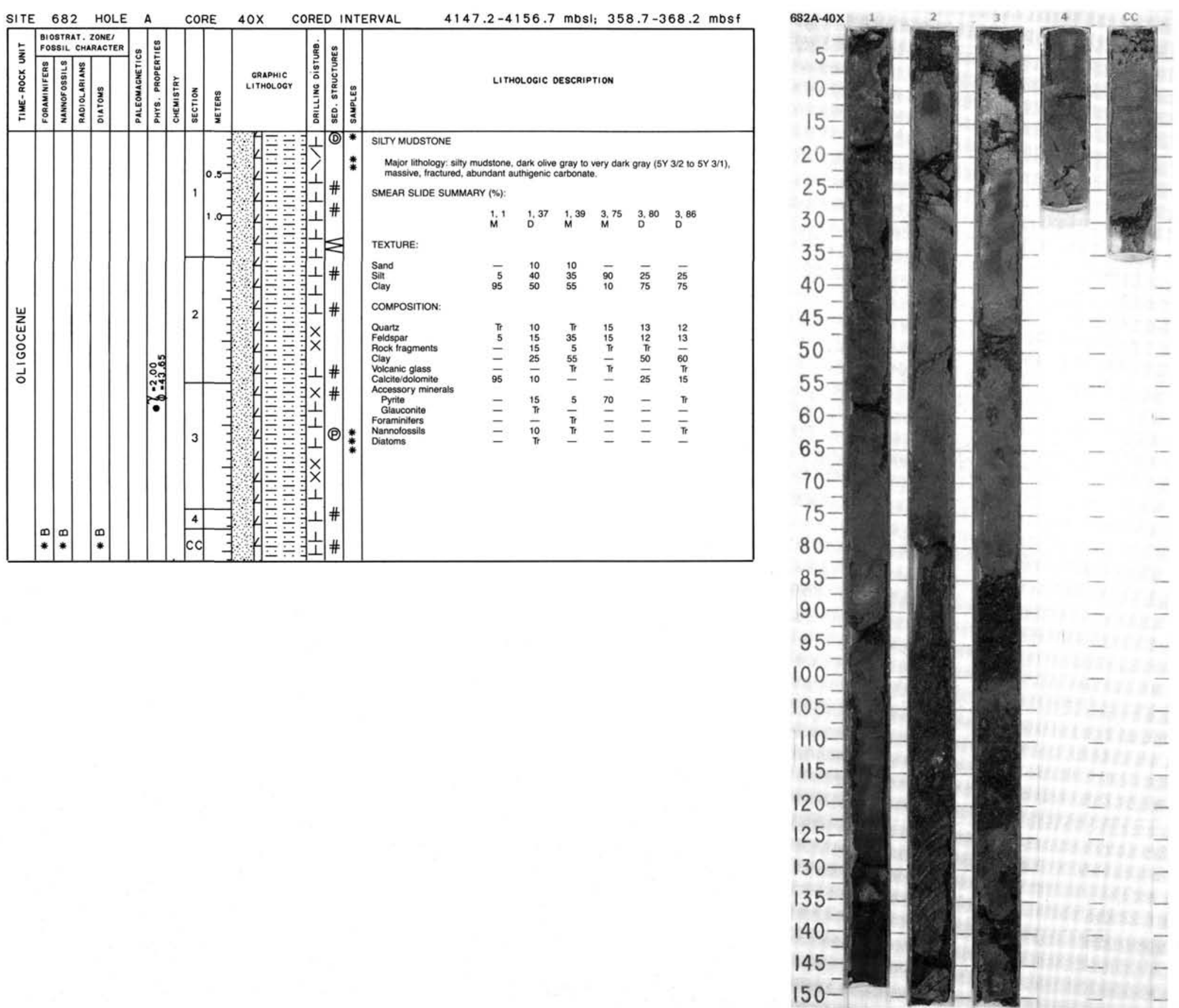


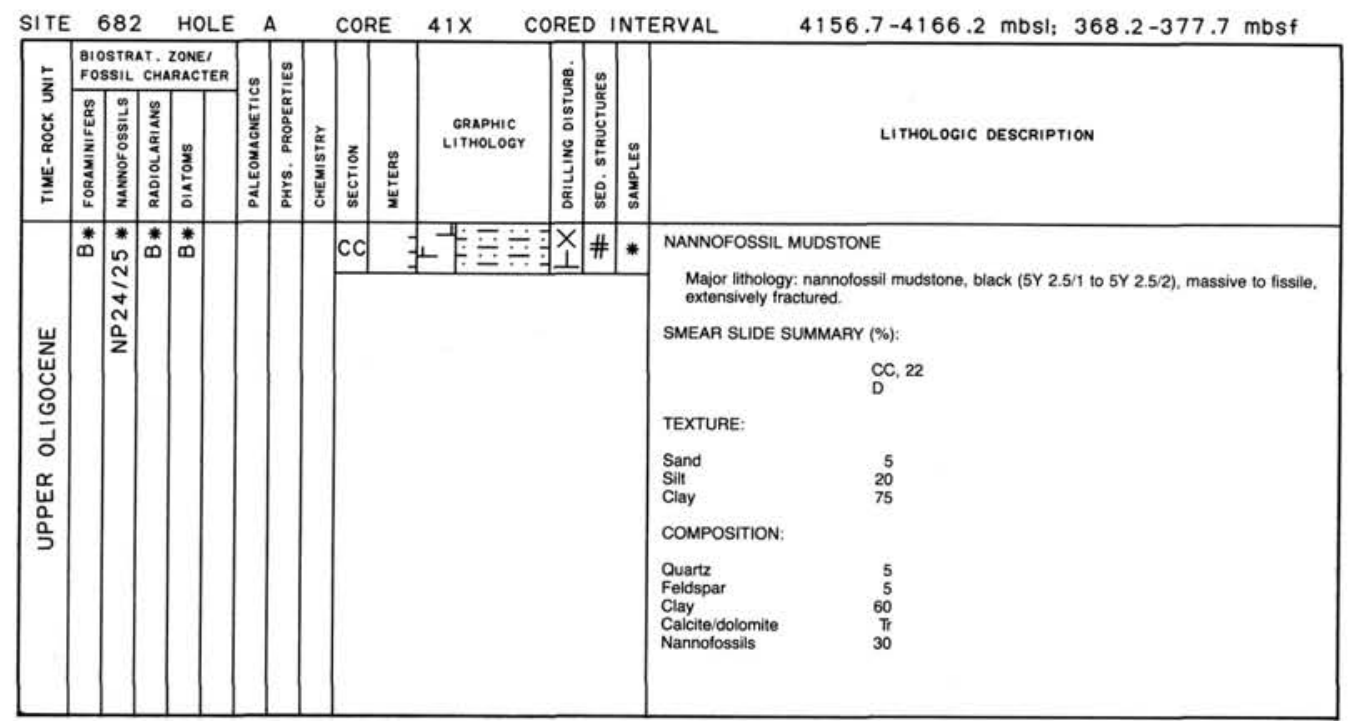

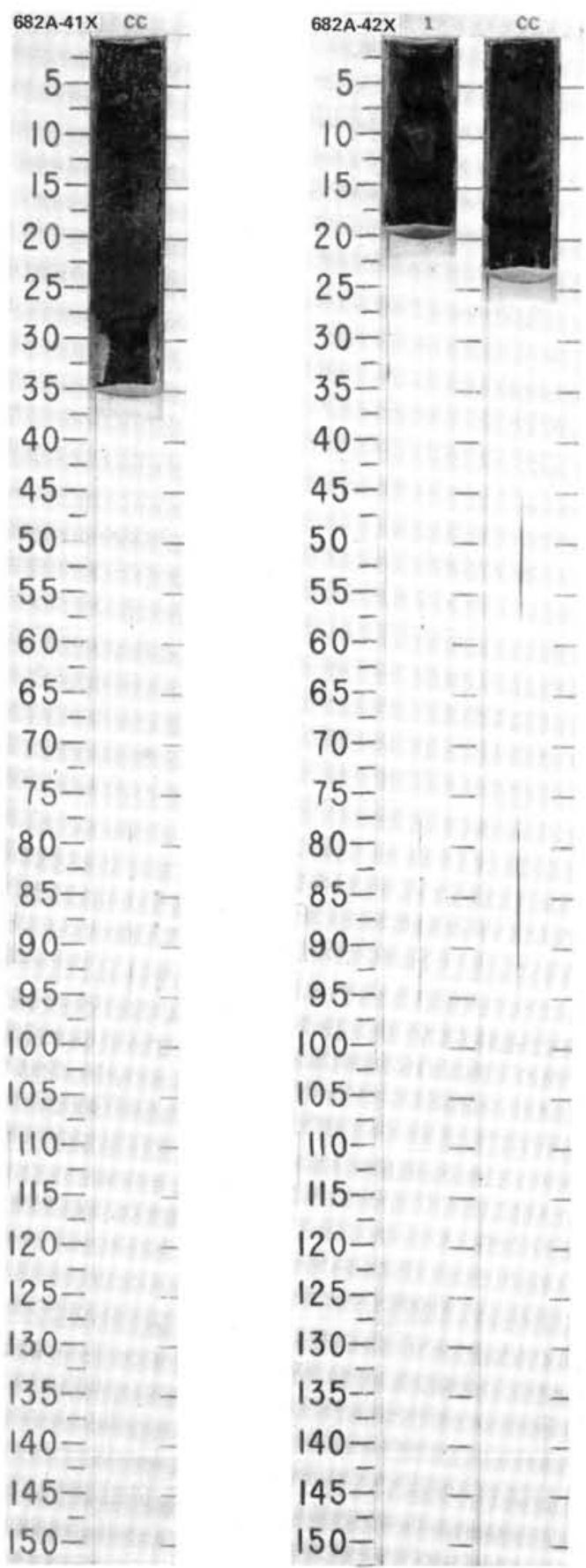

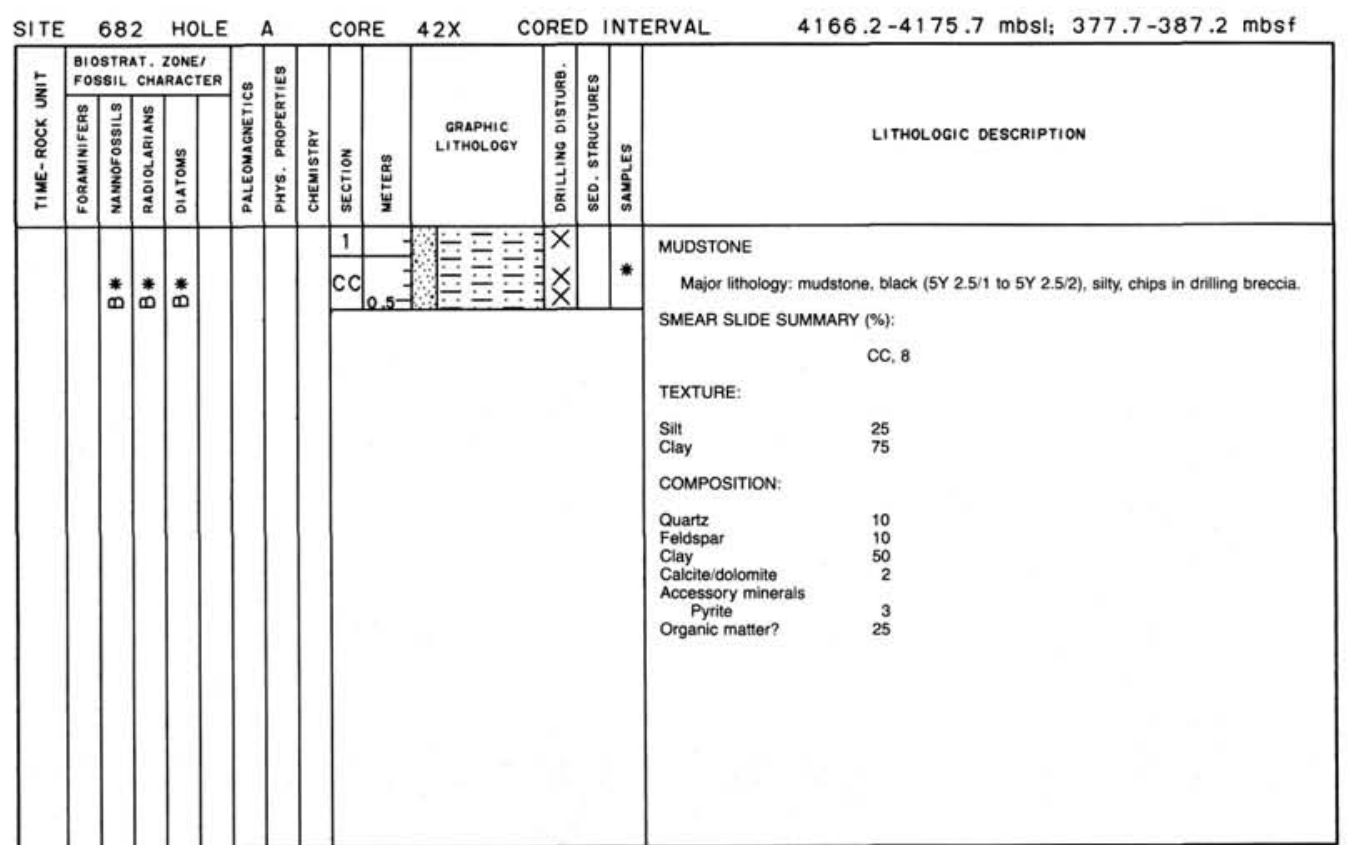

145 

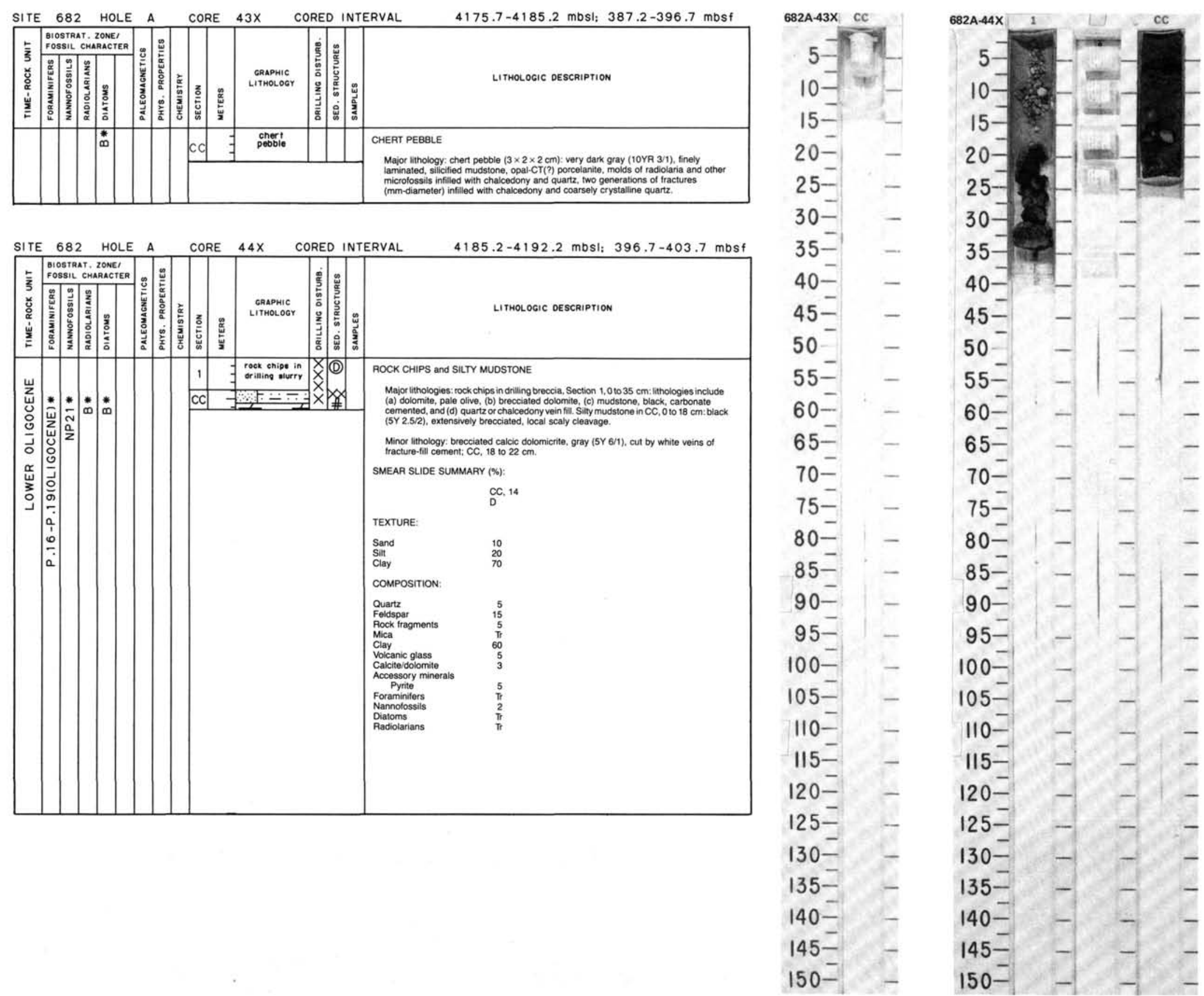

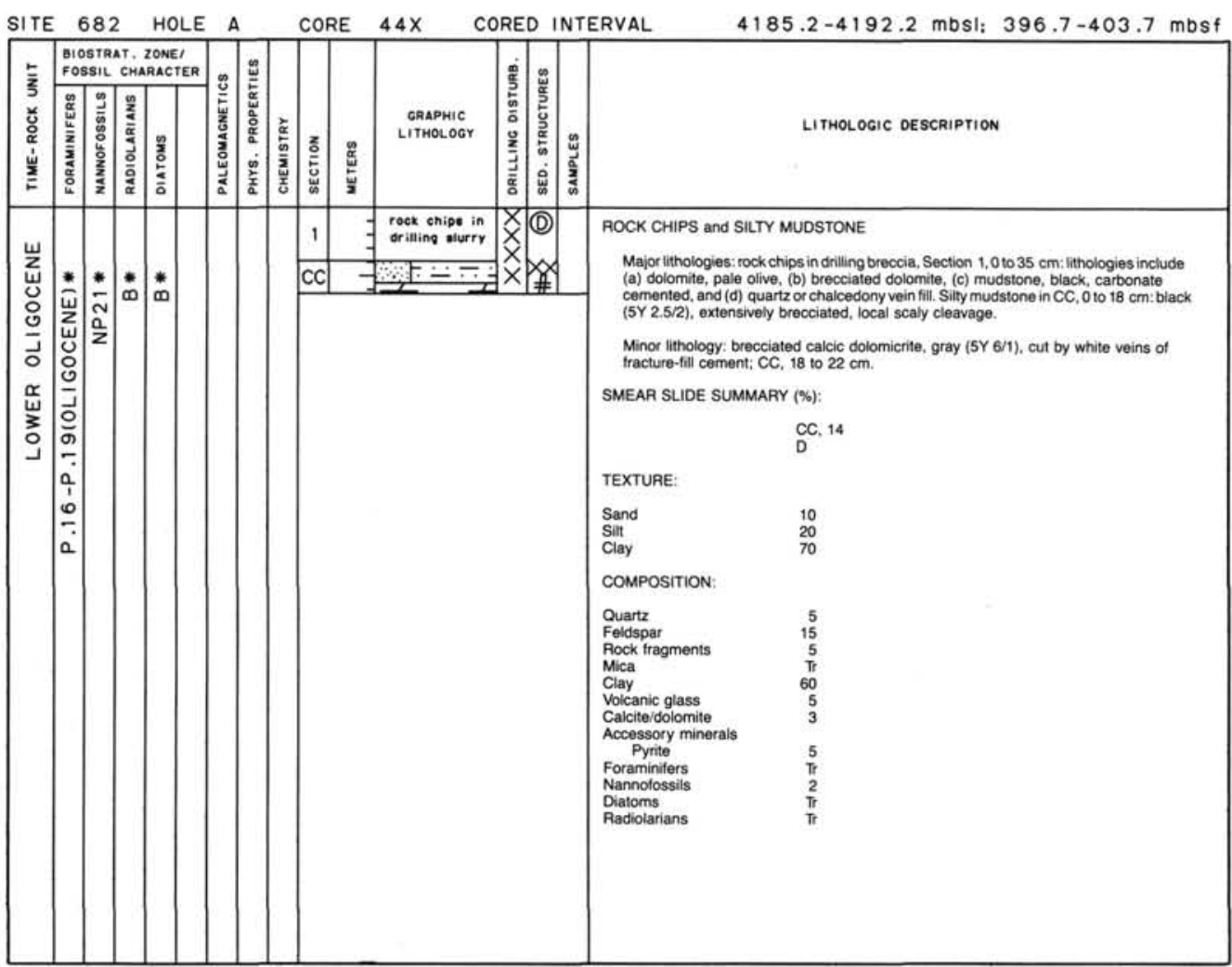



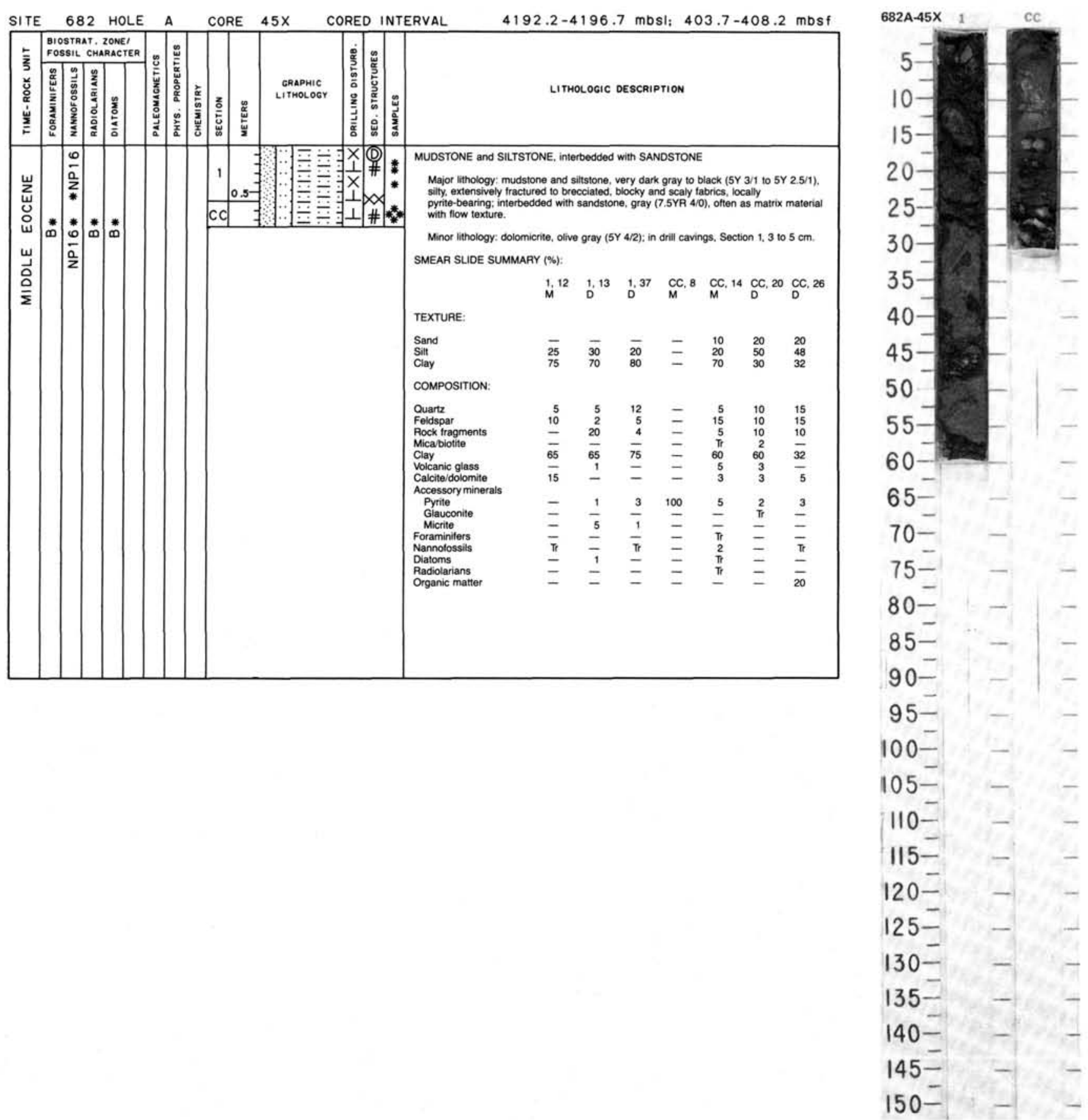

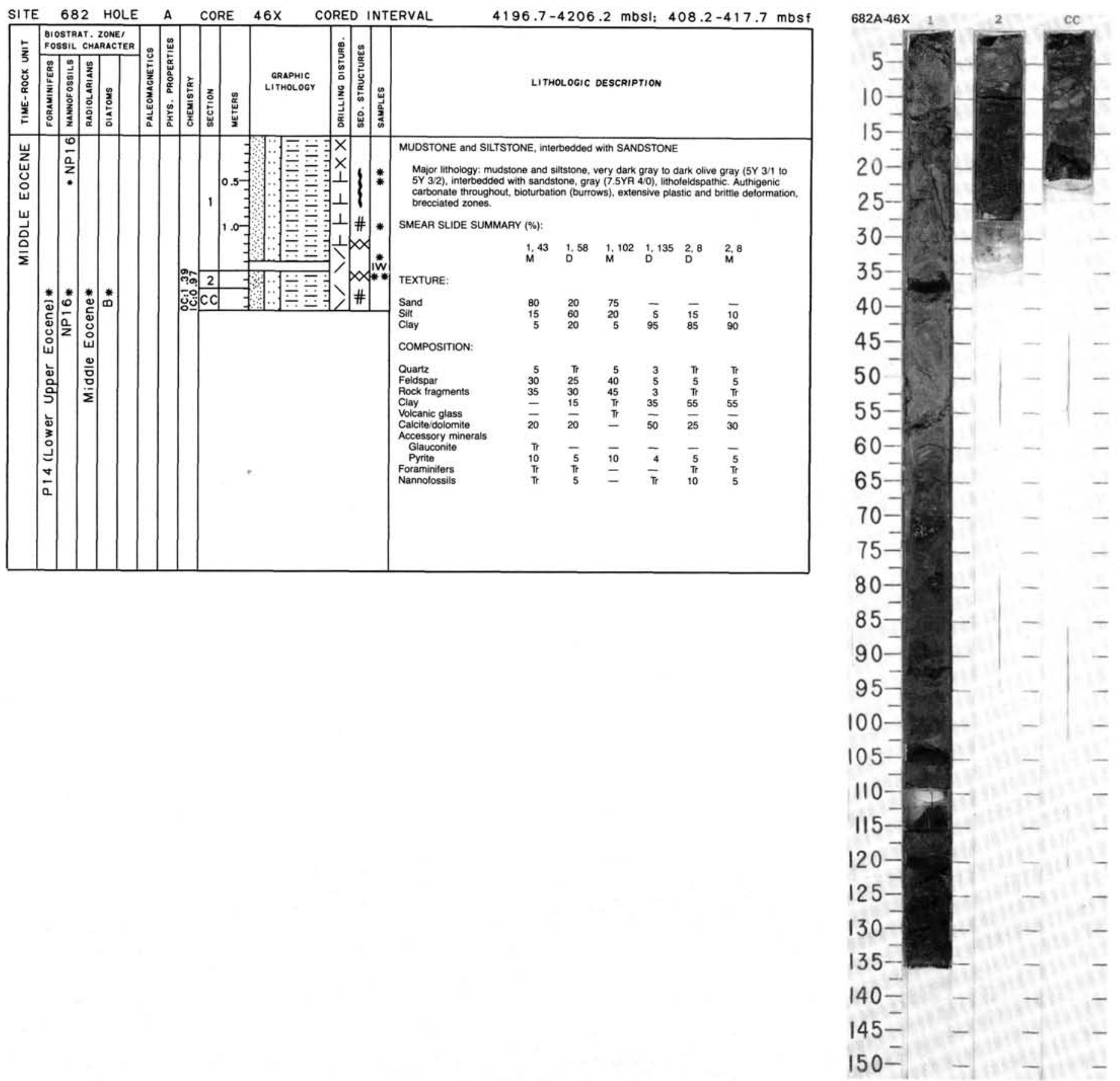

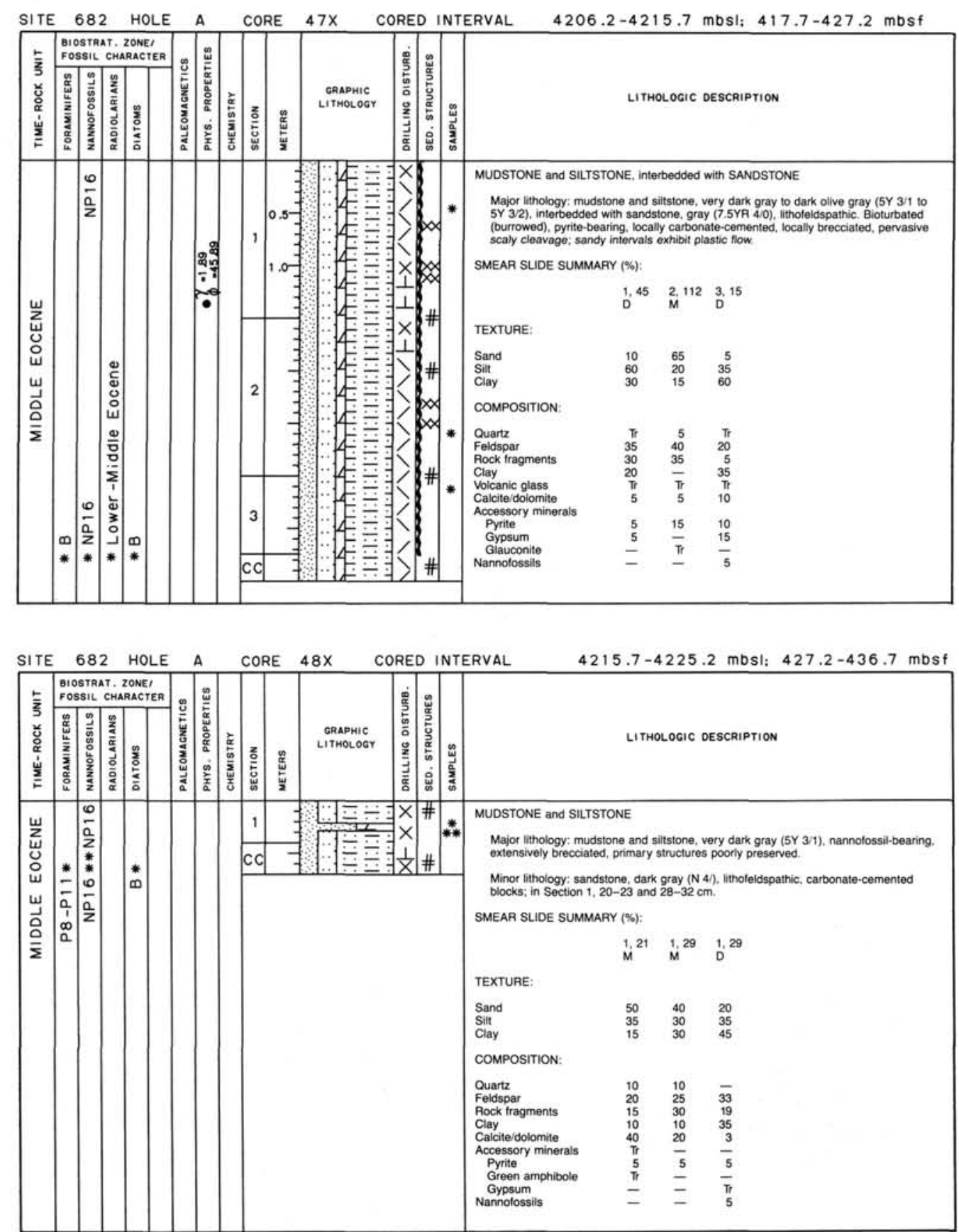

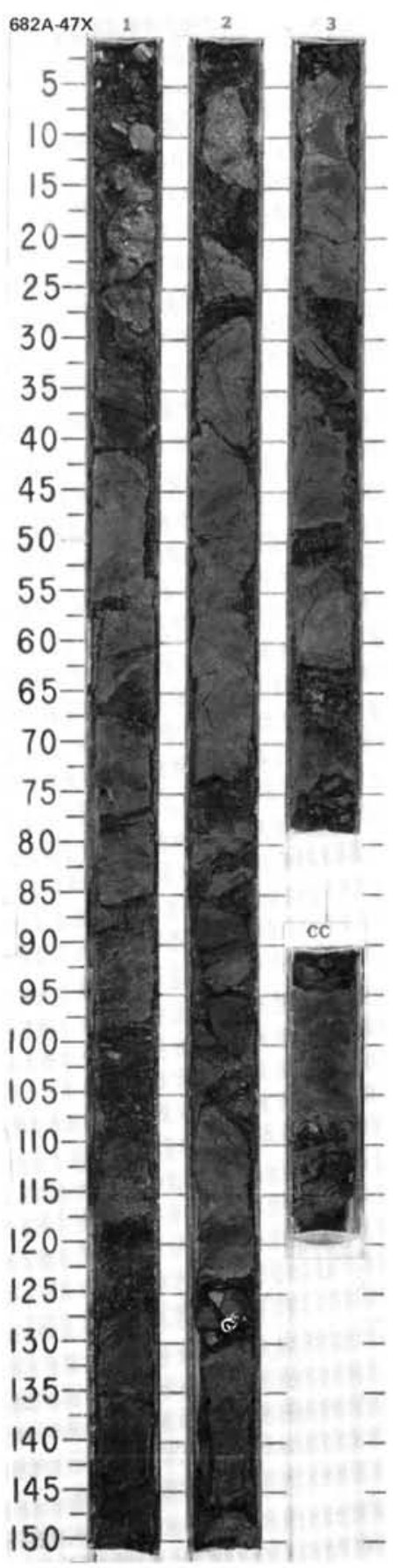

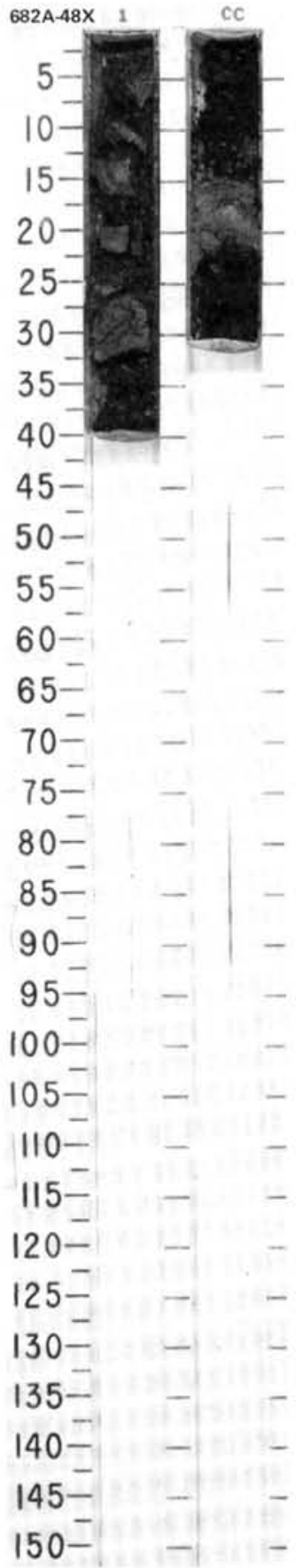

